Sporomorph Biostratigraphy,

Floral Changes, and

Paleoclimatology, Eocene and

Earliest Oligocene of the

Eastern Gulf Coast

U.S. GEOLOGICAL SURVEY PROFESSIONAL PAPER 1448 


\section{Sporomorph Biostratigraphy,}

Floral Changes, and Paleoclimatology, Eocene and Earliest Oligocene of the Eastern Gulf Coast

By NORMAN O. FREDERIKSEN

U.S. GEOLOGICAL SURVEY PROFESSIONAL PAPER 1448

Sporomorph taxon ranges are determined in the Eocene and earliest Oligocene of the eastern Gulf Coast; floral and climatic changes during this time are inferred

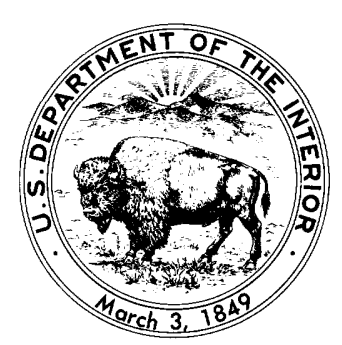




\section{DEPARTMENT OF THE INTERIOR}

DONALD PAUL HODEL, Secretary

\section{U.S. GEOLOGICAL SURVEY}

Dallas L. Peck, Director

\section{Library of Congress Cataloging in Publication Data}

Frederiksen, Norman O.

Sporomorph biostratigraphy, floral changes, and paleoclimatology, Eocene and earliest Oligocene of the eastern Gulf Coast.

(Geological Survey professional paper ; 1448)

Bibliography: $\mathbf{p}$.

Includes index.

Supt. of Docs. no.: I 19.16:1448

1. Spores (Botany), Fossil. 2. Paleobotany-Eocene. 3. Paleobotany-Oligocene. 4. Palynology-Gulf Coast (U.S.) I. Title. II. Series.

For sale by the Books and Open-File Reports Section, U.S. Geological Survey,

Federal Center, Box 25425, Denver, CO 80225 


\section{CONTENTS}

Abstract

Introduction.. $.6 \ldots$

Acknowledgments

Methods

Sample register -......

Biostratigraphy and correlation

Sections 2B, 3B, 4, 5 .

Section 2B $-\ldots \ldots \ldots \ldots$

Samples R1507A, B ….......................

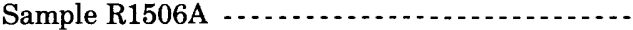

Sample R1506B

Sample R2353

Section 3B

Section 4

Section 5

Graphic correlation of sections 4 and 5 .............

Graphic correlation of sections $3 B$ and $4+5 \ldots \ldots$

Graphic correlation of sections $2 \mathrm{~B}$ and $3 \mathrm{~B}+4+5 \ldots \ldots \ldots$

Correlation within the Jacksonian Stage and adjacent

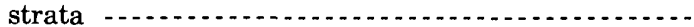

Comments on the practice of graphic correlation -......

Composite standard section ..........................

Calcareous microfossil zones -.....................

Stage boundary problems .............

Eocene-Oligocene boundary

Sporomorph ranges

Unconformities --

Rate of deposition, floral diversity and turnover, and

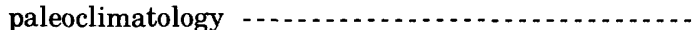

Floral diversity and turnover

Previous paleoclimatic conclusions -... . . . . . . . . . . .

Interpretation of plate 18

Comparison with other paleoclimatic data -...........

Comparison with models of evolution ...............

Systematics

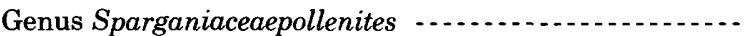
Sparganiaceaepollenites $\mathrm{cf}$ S. reticulatus ...........

Genus Emmapollis

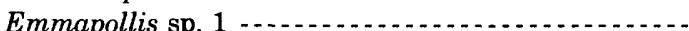

Genus Diporites

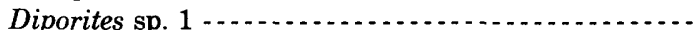

Genus Diporoconia

Diporoconia sp.

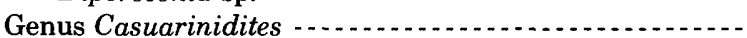

Genus Triporopollenites ........................

Triporopollenites palaeobetuloides group ...........

Triporopollenites pulcher group -....................

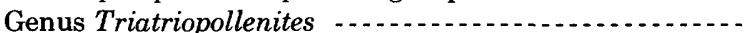

Triatriopollenites convexus group -..............

Triatriopollenites sparsus group -.................

Genera Platycarya and Platycaryapollenites ...........

Genus Subtriporopollenites -........................

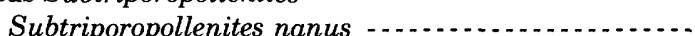

Genus Ulmipollenites ............................

Ulmipollenites thompsonianus ...................

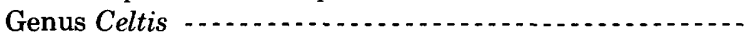

Celtis tschudyi group (triporate) ....................
Systematics-Continued

Genus ('iltis-Continued

Celtis tschudyi group (multiporate) ............. 51

Genus Corsinipollenites -........................... 52 Corsinipollenites? verrucatus-................. 52

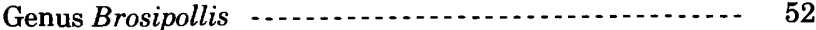

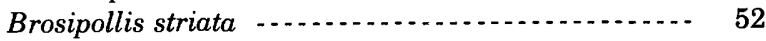

Genus Anacolosidites Anacolosidites sp. 1 .......................... 52

Genus Malvacipollis .................................. 52 Malvacipollis cf. M. tschudyi (................. 52

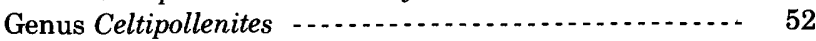
Celtipollenites gracilis .......................... 52

Genus Rousea -................................. 53 Rousea monilifera type (...................... 53

Genus Retibrevitricolpites -..................... 53 Retibrevitricolpites simplex ...................... 53

Genus Tetracolporopollenites ...................... 53 Tetracolporopollenites megadolium types -......... 53 Tetracolporopollenites prolatus .................. 53 Tetracolporopollenites brevis type ................. 53 Tetracolporopollenites lesquereuxianus type ......... 53

Genus Siltaria -................................ 54 Siltaria abouziarovae group -.................... 54

Genus Rhoipites .................................... 54 Rhoipites capax

Genus Boehlensipollis ......................... 54 Boehlensipollis aff. B. granulata ............. 54 Boehlensipollis verrucata -...................... 54

Genus Syncolporites -........ 55 Syncolporites? sp. 1 ( Syncolporites sp. 2 -.......................... 55

Genus Porocolpopollenites

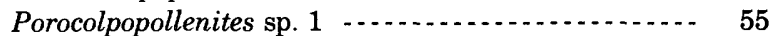

Genus Symplocos Symplocos? virginiensis group -................ 55 Symplocos? sp. 1 .......................... 55

Genus Lanagiopollis Lanagiopollis crassa type -.................. 56 Lanagiopollis eocaenica type Lanagiopollis hadrodictya -................... 57 Lanagiopollis sp. 1 . . . . Lanagiopollis sp. 2 (

Genus Bombacacidites Bombacacidites cf. B. nanobrochatus ............. 57

Bombacacidites aff. B. reticulatus -................ 58

Bombacacidites sp. 1 [ .

Bombacacidites sp. 2 (n..................... 58

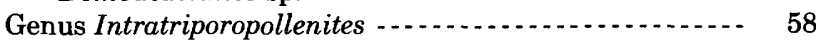
Intratriporopollenites pseudinstructus group -.....-. $\quad 58$ Intratriporopollenites? sp. 1 ................. 58

Genus Friedrichipollis -....................... 59 Friedrichipollis sp. 1 ........................ 59

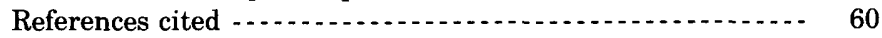

Index 


\section{ILLUSTRATIONS}

Plate 1. Spores and pollen grains

[Plates 1-16 follow index; plates 17, 18 are in pocket]

2-16. Angiosperm pollen grains

17. Composite standard sporomorph section for the Eocene and lowest Oligocene of the eastern Gulf Coast

18. Geological, biological, and paleoclimatic data plotted against the geochronological scale of Berggren and others (1985)

FIGURE 1. Summary diagram of formations in five stratigraphic sections analyzed for this paper

2. Sample localities of this paper

$3-6$. Occurrences and local ranges of operational taxonomic units in

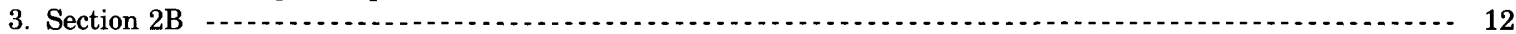

4. Section 3B

5. Section 4 (2.1.

6. Section 5 (n)

7, 8. Graphic correlation of sections 4 and 5 showing:

7. All events thought to be usable

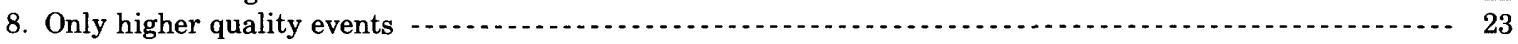

9, 10. Graphic correlation of sections $3 B$ and $4+5$ showing:

9. All events

10. Only higher quality events

11, 12. Graphic correlation of sections $2 B$ and $3 B+4+5$ showing:

11. All events -

12. Only higher quality events

13. Stratigraphic ranges of age-diagnostic operational taxonomic units found in sample R2353 of the Dobys Bluff Tongue, Kosciusko Formation, Clarke County, Miss. . . . . . .

14. Graphic correlation of composited sections $2 \mathrm{~A}$ (eastern Mississippi) and 3A (western Alabama) vs. section 1 (western Mississippi)

TABLE 1. Operational taxonomic units differentiated in this study

2. Comparison of numbers of operational taxonomic units whose ranges in the Eocene of the Gulf Coast are shown in different publications, and numbers of range bases and tops indicated as occurring within the Eocene or at the base or top of this series

3. Lithologic divisions, tentative formation assignments, and samples from the Albany core (section 5)

4. Initial ranking of presumed high-quality events in sections 4 and $5 \ldots \ldots$

5. Number of samples studied per geologic time interval by Frederiksen (1980c) and in this paper

6. Locations of illustrated specimens 


\title{
SPOROMORPH BIOSTRATIGRAPHY, FLORAL CHANGES, AND PALEOCLIMATOLOGY, EOCENE AND EARLIEST OLIGOCENE OF THE EASTERN GULF COAST
}

\author{
BY NORMAN O. FREDERIKSEN
}

\section{ABSTRACT}

This paper is a continuation of previously published work that dealt with the biostratigraphy and paleoclimatology of late middle Eocene to early Oligocene sporomorph assemblages from the eastern Gulf Coast. Here, the emphasis is on data from 48 new samples obtained from two continuous sections and two composite sections, from the base of the Eocene to the upper middle Eocene, of eastern Mississippi, Alabama, and western Georgia. One hundred sixty-four operational taxonomic units of sporomorphs were tabulated in this study. Of these, eight are new species of pollen grains that are formally named and described. Fourteen new taxonomic combinations are also proposed.

Graphic correlation was used to tie together the four stratigraphic sections. The sporomorph data support previously determined positions of formation contacts in the four sections. However, sporomorph range data suggest that the uppermost part of the Kosciusko Formation of eastern Mississippi correlates with the lower part of the $\mathrm{Cu}$ bitostrea sellaeformis Zone at Little Stave Creek (in western Alabama) rather than with the middle part of this zone, as suggested by some authors. I also tried graphic correlation of the sections I had previously studied, of the Jacksonian Stage and adjacent strata, but so few sporomorph range bases and tops are present in this part of the Eocene of this region that no conclusion could be reached about the thorny problem of correlating members of the Yazoo Clay across Mississippi.

In this paper, I drew the line of correlation on the graphic correlation charts on the basis of previously known formation contacts and used the sporomorph biostratigraphic events (range bases and tops) to check whether the positions of the formation boundaries appeared reasonable. In all the graphic correlation plots in this paper, drawing the line of correlation using all possible range bases and tops proved impossible because of the very wide scattering of data points. It was found much more useful to assign even a crude ranking of quality to each event and to plot only the higher quality events. Because most high rankings are assigned to range bases and tops of abundantly represented, relatively long-ranging taxa, I found that if a tradeoff must be made between numbers of samples to be examined and numbers of taxa to be tabulated, it is better to examine more samples but fewer taxa.

As a result of graphic correlation of the four new sections, together with my previous data on the Jacksonian Stage and adjacent strata, I have produced a composite standard section for the entire Eocene of the eastern Gulf Coast that includes ranges of 141 sporomorph operational taxonomic units. The value of this composite standard section is enhanced because the formations making up the section have previously been assigned to calcareous nannofossil zones, which have been related elsewhere to a geochronologic (time) scale. Thus, the geochronologic ages of the sporomorph range bases and tops in the eastern Gulf Coast are much better known than the ages in most previously published Eocene sporomorph-stratigraphic sections. The exact position of the Eocene-Oligocene boundary in the Gulf Coast is uncertain, but, on the basis of previous planktic foraminiferal and calcareous nannofossil work, it undoubtedly falls within the Shubuta Member of the Yazoo Clay rather than at the top of the Shubuta. Thus, my composite standard section, which includes the whole Yazoo Clay, includes the lowermost Oligocene as well as the Eocene.

On the basis of the stratigraphic and geochronologic data in the composite standard section, I have drawn a second section in which the primary scale is geologic time. One column of this geochronologic section shows inferred rates of deposition of the Eocene sediments in the composite standard section; the data in this column support the concept that a disconformity is likely to be present between the Tallahatta and Lisbon Formations. The Cocoa Sand Member of the Yazoo Clay may be associated with a disconformity caused by an apparent eustatic drop in sea level at about the end of NP17 time.

Additional columns of the geochronologic section show times and rates of changes of the angiosperm floras during Eocene time in the eastern Gulf Coast. These data indicate the existence of an early Eocene event, a rapid turnover of the earliest Eocene angiosperm flora reflecting the extinction of some Paleocene holdovers and the appearance (due to evolution and immigration) of new forms in the region. The rate of new operational taxonomic unit appearances is the highest such rate known for the Eocene of the eastern Gulf Coast, and I interpret this high rate to be due in large measure to rapid immigration of angiosperm taxa from Europe over the North Atlantic land bridge near the beginning of the Eocene. Accompanying the rapid change in the flora was a general increase in diversity during the first part of early Eocene time. After this early Eocene event, the angiosperm taxon diversity in the region remained rather constant and was accompanied by low rates of taxon turnover for about 9 million years. Then, at about $46 \mathrm{Ma}$, a middle Eocene event began that lasted about 4.5 million years, to about $41.5 \mathrm{Ma}$, and included in succession (1) a concentration of first appearances, (2) a concentration of last appearances, and (3) a second concentration of first appearances. This sequence of turnover pulses was accompanied by a rapid rise in diversity to a peak at about $45 \mathrm{Ma}$, followed by a long, more or less steady decline in diversity to a minimum at about 42-41.5 Ma. The middle Eocene event was followed by a period of steady diversity, evidenced by a lack of detectable turnover of angiosperm taxa, that lasted until the end of the Eocene. The Oligocene deterioration of Wolfe (=the terminal Eocene event of Wolfe) is manifested in the eastern Gulf Coast by two kinds of rapid changes in the pollen assemblages, a rise in relative frequency of an oaklike pollen species and a simultaneous concentration of angiosperm taxon last appearances leading to a decrease in taxon diversity; these changes probably did not commence until the very beginning of the Oligocene. Most turnover events affecting angiosperm pollen taxa in the Eocene and earliest Oligocene of the eastern Gulf Coast are difficult to interpret in terms of particular climates or openings and closings of migration routes, but the pattern seems clear that times of rapid climatic change and migration were interspaced with periods of gradual or no climatic change or migration. The apparent 5-million-year stasis in evolution of angiosperm taxa from the late middle Eocene to the end of the Eocene suggests that the Stationary model of evolution has more applicability to angiosperms than the Red Queen model. 


\section{INTRODUCTION}

Many papers have been published that are concerned with the taxonomy and distribution of Eocene sporomorphs or with the geological, botanical, or paleoclimatic implications of Eocene sporomorph distributions in the Gulf Coast. However, most of these studies did not deal with an entire Eocene section in this region, and, except for Elsik (1974a), no attempt has been made to consider these topics together for the Eocene as a whole.

Previously published work, particularly on the Claibornian Stage (lower Eocene to upper middle Eocene), has been concentrated on detrital sediments mainly from the western and central Gulf Coast region. In this paper, the emphasis is on two downdip sections in the eastern Gulf Coast that are entirely calcareous, composed of limestone, marl, and calcareous clay and sand. A disadvantage of such rocks is that they contain fewer taxa of sporomorphs per sample than do rocks formed in more nearshore marine to nonmarine environments as in Texas and the upper Mississippi Embayment. However, there are two distinct advantages of using the mainly marine sequence of the eastern Gulf Coast for constructing a standard Eocene sporomorph section: first, the rocks are much better correlated with the standard Eocene sections of Europe, on the basis of calcareous nannofossils, planktic foraminifers, and dinoflagellates, than are the less marine sections to the west; and second, reworked sporomorphs are much less of a problem in the mainly offshore marine rocks of the eastern Gulf Coast than in the more terrigenous sections to the west.

This paper is a continuation of work done previously in the eastern Gulf Coast on the Eocene and early Oligocene sporomorph taxonomy and biostratigraphy of the Jacksonian Stage and adjacent strata (that is, the sequence from the upper middle Eocene to the lower Oligocene; from the upper Claibornian Stage to the lower Vicksburgian Stage; from the Gosport and Cockfield Formations to the Bumpnose, Forest Hill, and Red Bluff Formations; Frederiksen, 1969, 1973, 1980c). In this paper, new data are provided, particularly for the sequence from the base of the Eocene to the top of the Lisbon Formation (upper middle Eocene); these data are then integrated with those previously obtained from the higher part of the Eocene. In particular, the purposes of this paper are to discuss, as needed, the taxonomy of the most important sporomorphs observed, to list the taxa present in samples from several stratigraphic sections of the region, to construct a composite standard sporomorph-stratigraphic section for the entire Eocene of the study region using the method of graphic correlation, and to consider the implications of the sporomorph ranges in the composite standard section for geology (for example, in terms of the presence of possible unconformities), botany (for example, floral turnover rates), and paleoclimatology.

During the process of graphic correlation, several problems appeared that do not seem to have been adequately treated in the published literature. Therefore, another purpose of this paper became to describe and discuss certain practical problems in graphic correlation.

One hundred sixty-four operational taxonomic units (OTU's) were tabulated in this study (table 1). These OTU's are of various taxonomic ranks and include a generic complex (Momipites-Plicatopollis-Platycaryapollenites complex), genera (for example, Corollina spp.; Graminidites spp.), form-species groups (for example, Brosipollis, other striate species; Siltaria abouziarovae group), subdivisions of species groups (for example, Celtis tschudyi group, triporate; C. tschudyi group, multiporate), species types, each of which may be thought of as a form-species sensu lato or which may include several form-species that could not easily be differentiated (for example, Platycarya platycaryoides type; Lanagiopollis eocaenica type), individual formspecies (for example, Plicatopollis triradiata; Gothanipollis sp. 1; Bombacacidites cf. B. nanobrochatus), and subdivisions of species (for example, Porocolpopollenites ollivierae, tricolporate and tetracolporate forms). Many additional taxa were found, and some of these are illustrated in the plates but are not discussed in the text or given OTU numbers.

OTU's listed in table 1 represent many but not all of the sporomorphs in the Eocene of the eastern Gulf Coast. In my study of sporomorphs from the Jacksonian and adjacent strata of this region (Frederiksen, 1980c), I illustrated and gave names for all of the 174 taxa found. In the part of the present study that deals with the upper part of the Sabinian Stage and the Claibornian Stage, I have disregarded (1) most spores and many of the gymnosperm pollen grains (except for those listed in table 1), (2) most of the fagaceous pollen grains belonging to the form-genera Cupuliferoipollenites, Cupuliferoidaepollenites, Quercoidites, Siltaria, Verrutricolporites, and Araliaceoipollenites, as well as (3) Momipites coryloides Wodehouse 1933 and M. microfoveolatus (Stanley 1965) Nichols 1973; all these sporomorphs have long ranges, and most of them are found throughout the Eocene. For this paper, I also disregarded most monosulcate pollen grains and many of the reticulate tricolpate and tricolporate grains because these are difficult to classify into meaningful OTU's and require more detailed study than is justified by their stratigraphic importance. 
TABLE 1.-Operational taxonomic units (OTU's) differentiated in this study (aside from those illustrated in the plates but not shown on the range charts)

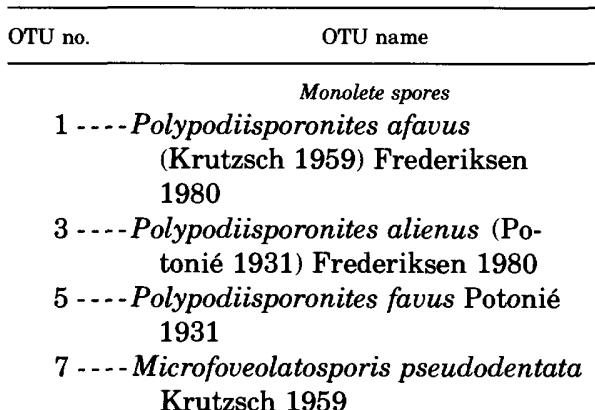

Trilete spores

9 -. - Cyathea? stavensis (Frederiksen 1973) Frederiksen 1980

13 -...-Granulatisporites luteticus (Krutzsch 1959) Frederiksen 1980

15 -... Undulatisporites concavus Kedves 1961

17 ... - Lycopodium venustum Frederiksen 1973

23 -..- Sphagnum triangularum (Mamczar 1960) Frederiksen 1980

Gymnosperm pollen

25 - . - Cedrus piniformis Zaklinskaya 1957

27 ... Ephedra claricristata

Shakhmundes 1965

29 ... Ephedra exiguua Frederiksen 1980

31 ...-Ephedra hungarica type

33 ...-Ephedripites subgenus Spiralipites spp.

35 - . - Corollina spp.

Monoporate pollen

37 ...-Graminidites spp.

39 - . - Milfordia hungarica (Kedves 1965)

Krutzsch \& Vanhoorne in

Krutzsch 1970

41 -... Milfordia incerta (Pflug \& Thomson in Thomson \& Pflug 1953)

Krutzsch 1961

43 - . - Milfordia minima Krutzsch 1970

45 - - - Sparganiaceaepollenites cf. $S$. reticulatus Krutzsch \& Vanhoorne 1977

47 - . - Aglaoreidia pristina Fowler 1971

49 .... Emmapollis sp. 1

51 ...-Diporites sp. 1

$$
\text { Diporate pollen }
$$

53 - . . . "Diporites" sp. 2

\section{Triporate pollen}

55 - . . Triporopollenites palaeobetuloides group

57 - . . Triporopollenites pulcher group

59 -... Triatriopollenites convexus group

63 ... Triatriopollenites galiformis (Gladkova 1965) n. comb.

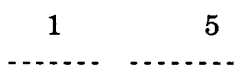

\begin{tabular}{cc}
1 & $6-9$ \\
\hdashline$-\ldots$ & $-\ldots .-$ \\
1 & $13-16$
\end{tabular}
TABLE 1.-Operational taxonomic units (OTU's) differentiated in this study-Continued

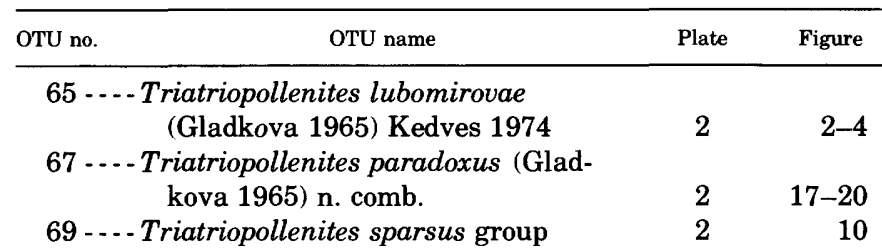

73 ... Triatriopollenites turgidus (Pflug in Thomson \& Pflug 1953) Frederiksen 1979

75 - . - Momipites flexus Frederiksen 1979

77 -..-Momipites tenuipolus group (Platycaryapollenites type)

79 -. - Momipites tenuipolus group (Paleocene type)

81 -..-Platycarya platycaryoides type

83 .... Platycaryapollenites swasticoidus (Elsik 1974) Frederiksen \& Christopher 1978

85 -. - Platycaryapollenites triplicatus (Elsik 1974) Frederiksen \& Christopher 1978

87 .... Platycaryapollenites spp.

91 -.-Plicatopollis magniorbicularis Frederiksen 1983

93 -...-Plicatopollis triorbicularis type of Frederiksen \& Christopher 1978

95 - . - Plicatopollis triradiata (Nichols 1973) Frederiksen \& Christopher 1978

97 -. . Momipites-Plicatopollis-Platycaryapollenites complex

$99 \ldots$... Jarzenipollis trina (Stanley 1965) Kedves 1980

101 -..- Paraalnipollenites confusus (Zaklinskaya 1963) Hills \& Wallace 1969

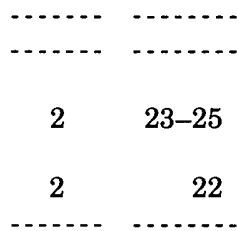

103 --.-Subtriporopollenites anulatus Pflug \& Thomson in Thomson \& Pflug 1953

105 -...-Subtriporopollenites nanus (Pflug \& Thomson in Thomson \& Pflug 1953) Frederiksen 1980

107 . . . Carya $<29 \mu \mathrm{m}$

109 ... Carya $>28 \mu \mathrm{m}$

111 .... Ulmipollenites krempii (Anderson 1960) Frederiksen 1979

113 --- Ulmipollenites thompsonianus (Traverse 1955) n. comb.

115 -..- Ulmipollenites tricostatus (Anderson 1960) Frederiksen 1980

117 - . - Ulmipollenites undulosus Wolff 1934

119 ...-Labrapollis globosa (Pflug in Thomson \& Pflug 1953) Krutzsch 1968

121 - - - Pistillipollenites macgregorii Rouse 1962

123 ... Celtis tschudyi group (triporate)

125 -... Corsinipollenites oculus-noctis (Thiergart 1940) Nakoman 1965

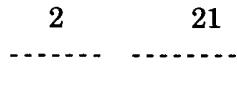

$2 \quad 26,27$

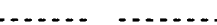

3

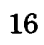

27 .... Corsinipollenites parviangulus Frederiksen 1983 
TABLE 1.-Operational taxonomic units (OTU's) differentiated in this study-Continued

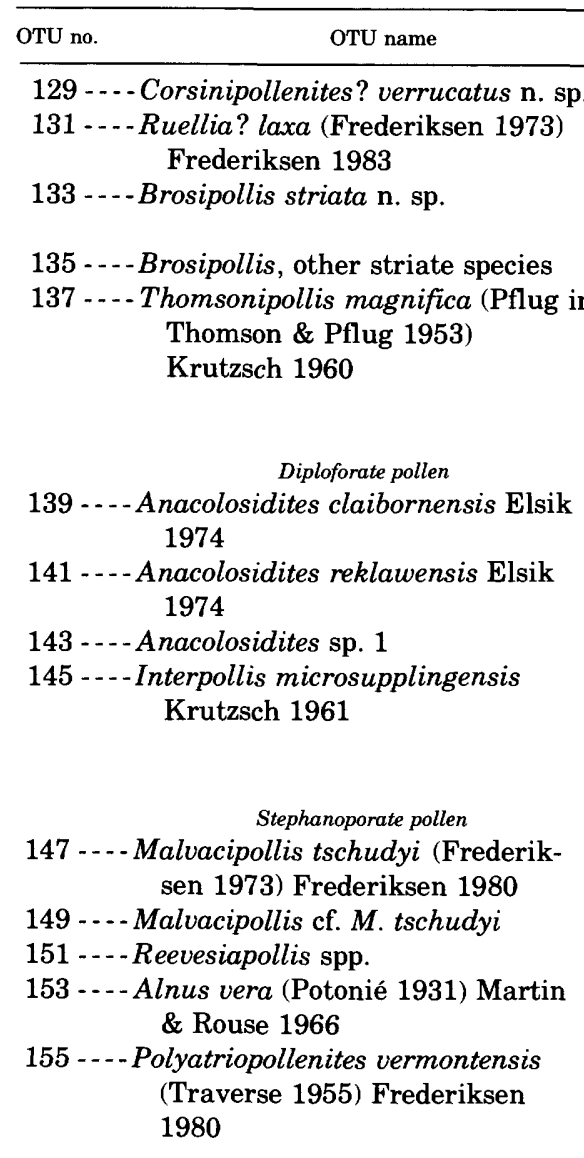

Forate pollen

157 .... Celtipollenites gracilis $\mathrm{n}$. sp.

159 .... Celtis tschudyi group (multiporate)

161 ...- Chenopodipollis spp.

163 -..-Parsonsidites conspicuus Frederiksen 1973

165 -. _ Juglans nigripites Wodehouse 1933

167 .... Juglanspollenites infrabaculatus Frederiksen 1973

169 ...-Lymingtonia cf. L. rhetor Erdtman 1960

Monosuleate pollen

171 ...-Arecipites rousei Frederiksen 1983

173 -...-Liliacidites vittatus Frederiksen 1973

175 -... Confertisulcites fusiformis Frederiksen 1973

177 .... Longapertites spp.

Ring-sulcate pollen

179 .... Proxapertites spp.

181 -... - Spinizonocolpites prominatus

(McIntyre 1965) Stover \& Evans 1973

$10-14$

$5 \quad 15-19$
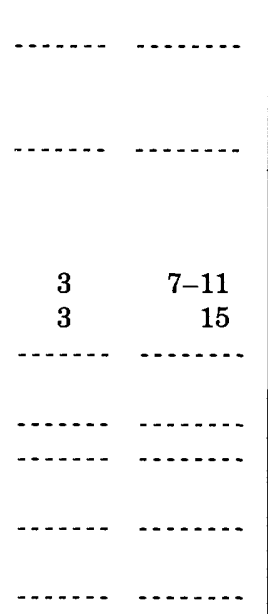

$6 \quad 3-11$
TABLE 1.-Operational taxonomic units (OTU's) differentiated in this study-Continued

\begin{tabular}{|c|c|c|}
\hline OTU name & Plate & Figure \\
\hline \multicolumn{3}{|l|}{ Dicolpate pollen } \\
\hline $183--$ Dicolpopollis spp. & 6 & $12-19$ \\
\hline \multicolumn{3}{|l|}{ Tricolpate pollen } \\
\hline $185 \ldots$-.. Eucommia type (tricolpate) & 7 & 1 \\
\hline $\begin{array}{r}187 \ldots \text { Quercoidites inamoenus (Taka- } \\
\text { hashi 1961) Frederiksen } 1980\end{array}$ & & \\
\hline $\begin{array}{l}189 \text { - Platanus occidentaloides Frederik- } \\
\text { sen } 1980\end{array}$ & & \\
\hline $\begin{array}{c}191 \text {-... Salixipollenites parvus } \text { Frederiksen } \\
1980\end{array}$ & & \\
\hline 193 -..-Rousea araneosa (Frederiksen & & \\
\hline 1973) Frederiksen 1980 & -....... & -- \\
\hline $195 \ldots$ - Rousea monilifera type & - . . . & ........ \\
\hline $\begin{array}{l}197 \text {. . - Tricolpites asper Frederikson } 1978 \\
199 \ldots \text {. . Tricolpites interangulus Newman }\end{array}$ & -...... & \\
\hline 1965 & 7 & $13-15$ \\
\hline $\begin{array}{c}201 \text {-... Tricolpites reticulatus Couper } 1953 \\
203 \text { - Retitrescolpites anguloluminosus } \\
\text { (Anderson 1960) Frederiksen }\end{array}$ & 7 & 11,12 \\
\hline
\end{tabular}

205 -.- Aesculiidites circumstriatus (Fairchild in Stover et al. 1966) Elsik 1968

207 -..-Retibrevitricolpites simplex n. sp.

209 . . . Enopadios reticulatus Elsik \& Dilcher 1974

211 - . . - Striatopollis terasmaei (Rouse 1962) Frederiksen 1980

Tricolporate pollen

213 -..-Eucommia type (tricolporate)

215 .... Chrysophyllum? brevisulcatum (Frederiksen 1973) Frederiksen 1980

217 .... Cyrillaceaepollenites megaexactus (Potonié 1931) Potonié 1960

219 - . - Cyrillaceaepollenites barghoornianus (Traverse 1955) Potonié 1960

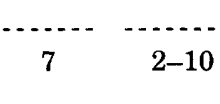

7

16

-.....

8

$1-5$

221 ... Tetracolporopollenites megadolium type (short colpi)

223 .... Tetracolporopollenites megadolium type (long colpi)

225 ... Tetracolporopollenites prolatus $\mathrm{n}$. sp.

227 . . . Pseudolaesopollis ventosa (Potonié 1931) Frederiksen 1979

229 -. . Siltaria abouziarovae group

231 -..-Araliaceoipollenites granulatus (Potonié 1931) Frederiksen 1980

233 -..-Araliaceoipollenites profundus Frederiksen 1980

235 -... Nuxpollenites claibornensis Elsik 1974

237 -...-Nuxpollenites crockettensis Elsik 1974

239 -... Nuxpollenites psilatus Frederiksen 1979

241 -...- Ilexpollenites auriculoides Elsik 1974

\section{6,7 \\ 8,9 \\ 16}

$8 \quad 17,18$

$8 \quad 10-15$

$8 \quad 19-22$

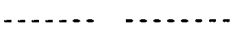

$10 \quad 14-16$ 
TABLE 1.-Operational taxonomic units (OTU's) differentiated in this study-Continued

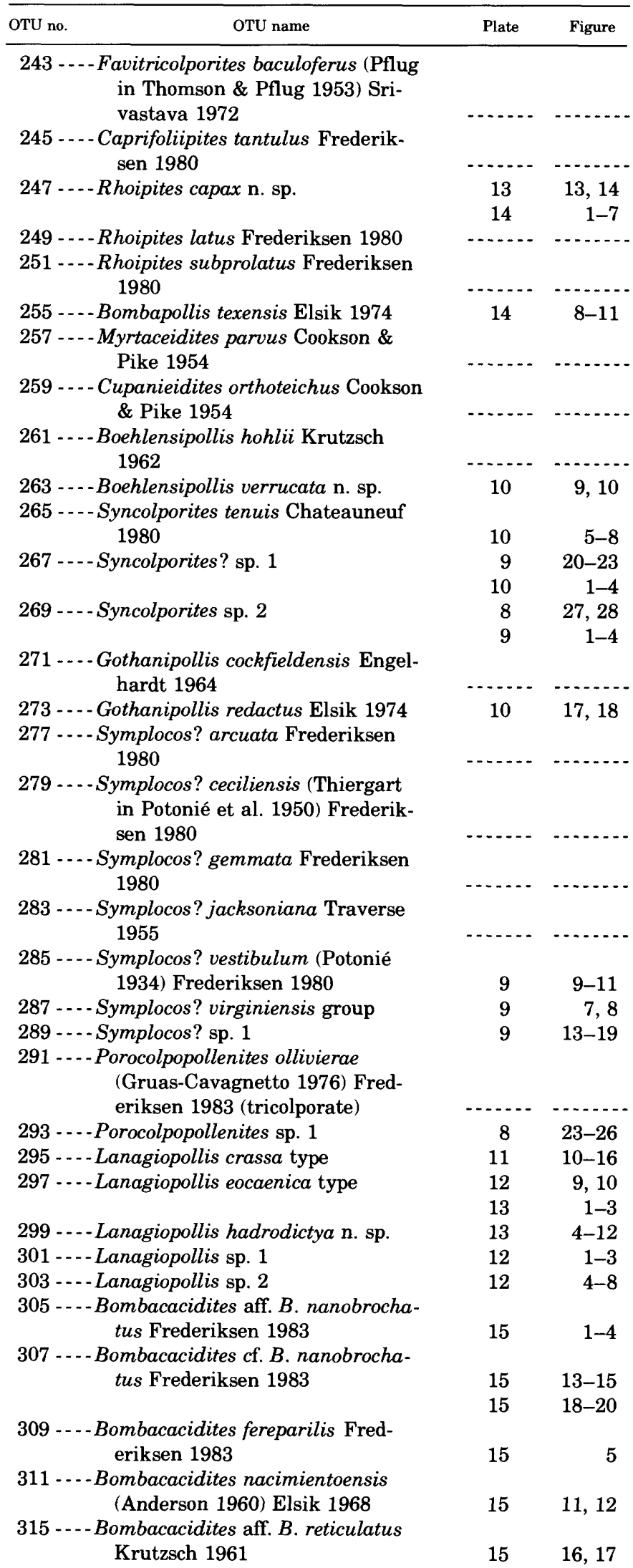

TABLE 1.-Operational taxonomic units (OTU's) differentiated in this study-Continued

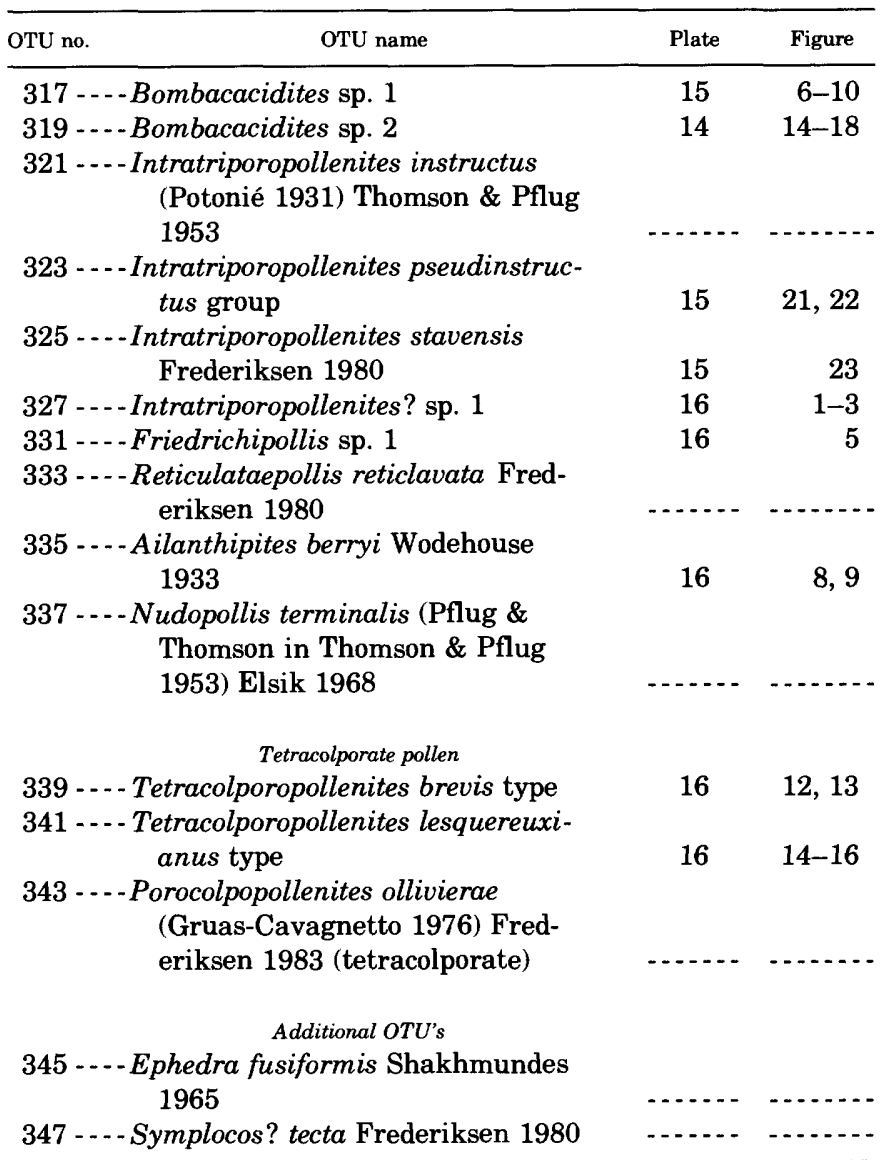

Figure 1 summarizes the five stratigraphic sections (some of them composite sections) examined for this paper. The largest part of the paper is concerned with the upper part of the Sabinian Stage and the Claibornian Stage. Primary analyses (lists of OTU's) were obtained from 48 samples (figs. 3-6), and 4 additional samples (R1138A, R1155, R2355A, and R2587B) were used to obtain photomicrographs for the plates. Information about these 52 samples is provided in the "Sample Register," and figure 2 is a map showing the localities from which the samples came.

\section{ACKNOWLEDGMENTS}

I wish to thank D.T. Dockery III and W.A. Gilliland, Mississippi Bureau of Geology, and R.S. Young, North American Exploration Inc., for providing several of the samples analyzed in this paper, and L.E. Edwards, U.S. Geological Survey, for lending me her dissertation slides. I am grateful to J.A. Barron and L.E. Edwards, U.S. Geological Survey, B.H. Tiffney, Yale University, C.W. Copeland, Geological Survey of Alabama D.T. Dockery III, Mississippi Bureau of Geology, and 


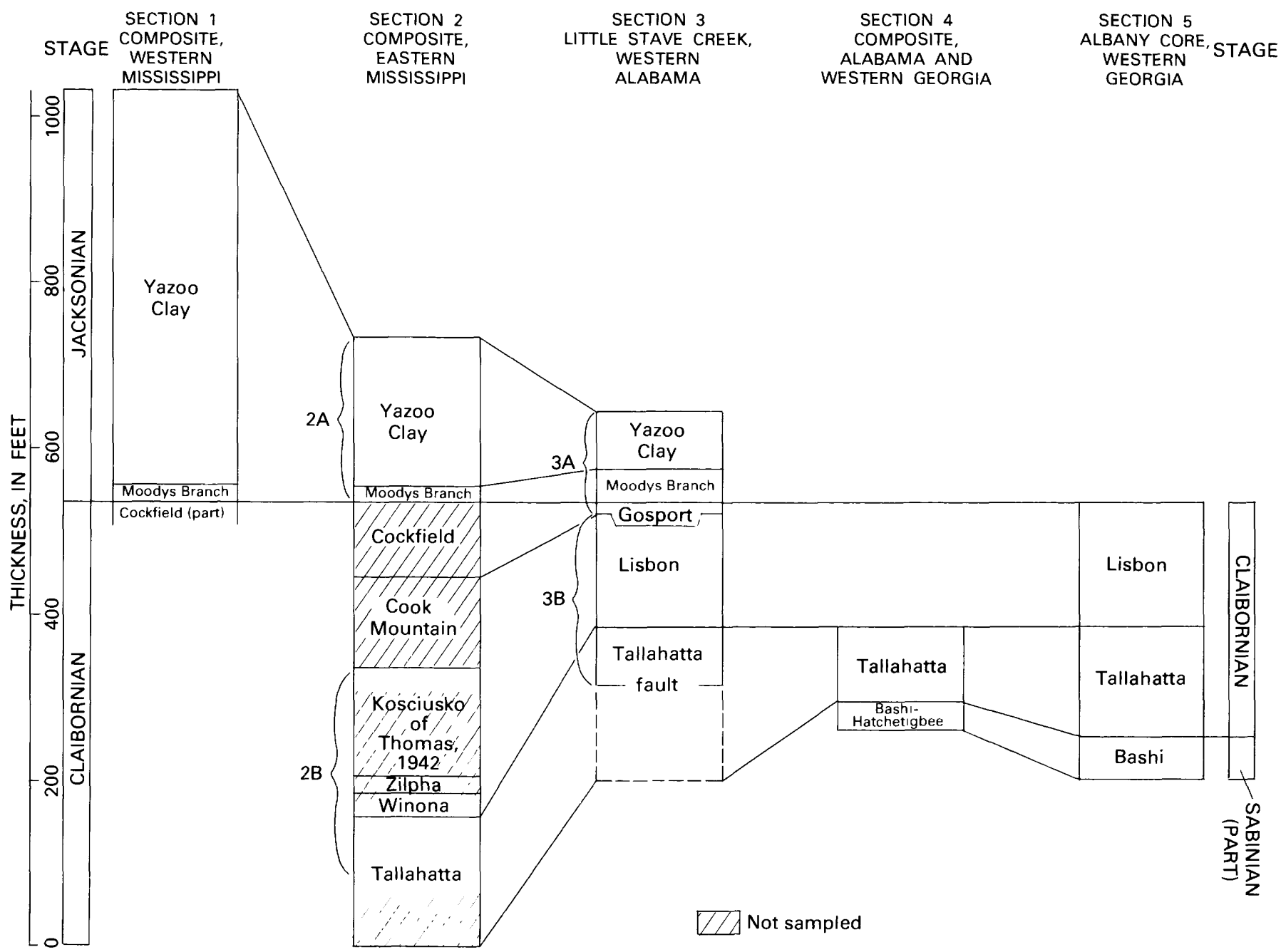

FIGURE 1.-Summary diagram of formations in five stratigraphic sections analyzed for this paper. The presumed thickness of the Tallahatta Formation that has been cut out by faulting at Little Stave Creek is shown by dashed lines in section 3.

P.F. Huddlestun, Georgia Geologic Survey, for reviewing various parts and drafts of this paper and for providing useful criticism.

\section{METHODS}

Samples having $\mathrm{AC}$ and $\mathrm{R}$ numbers were prepared by means of standard acid maceration; those having UCR numbers (dissertation slides of L.E. Edwards) were prepared by means of acetolysis. All samples underwent heavy liquid separation using $\mathrm{ZnCl}_{2}$ or $\mathrm{ZnBr}_{2}$ and were mounted in glycerine jelly. Coordinates listed in the holotype descriptions and in table 6 locate the specimens on Leitz microscope 871956 at the U.S. Geological Survey, Reston, Va. On the stage of this microscope, the $\mathrm{X}$-axis coordinates increase to the right and the
Y-axis coordinates increase toward the front; the coordinates of the midpoint of a standard $1-\times 3$-in slide are $38.8 \times 102.5$ (for conversion of coordinates to other microscopes, see Frederiksen, 1978).

In the section "Biostratigraphy and Correlation," I assume that the reader is familiar with the principles of graphic correlation. Papers in which this technique has been used and discussed are listed by Edwards (1984), and some additional discussion of the technique is given in this paper in the section "Comments on the Practice of Graphic Correlation." However, in this paper I did not use graphic correlation altogether in the traditional way. Previous workers have used graphic correlation to find a line of correlation linking strata in sections between which the correlations were uncertain or unknown. In this paper, formation boundaries 


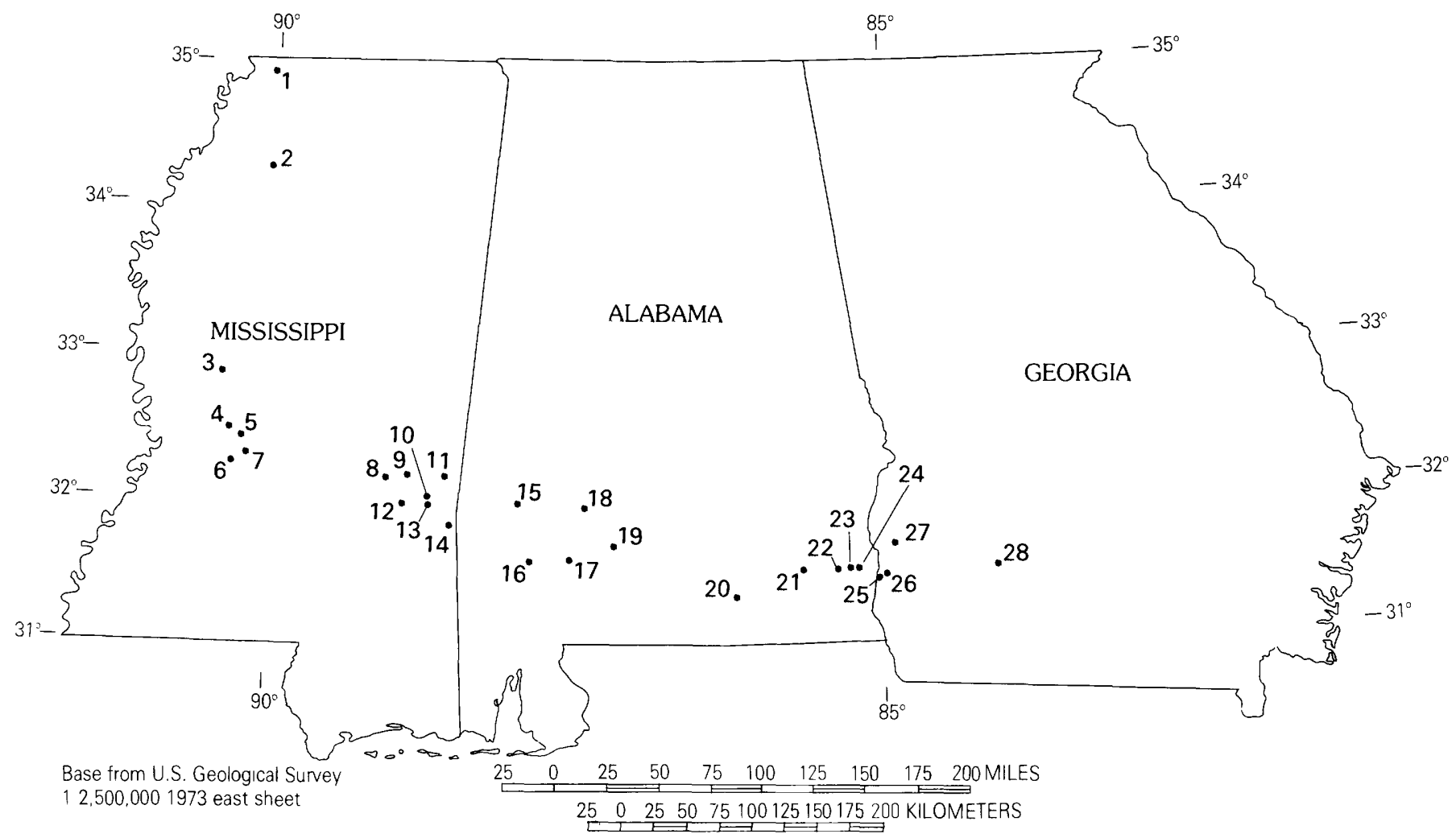

FIGURE 2.-Sample localities of this paper. See the "Sample Register" for details about the new samples.

Locality 1. Sample R2355A (photographed specimens).

2. Sample R1155 (photographed specimens).

3. Section 1 of Frederiksen (1980c); part of section 1 of this paper.

4. Section 2 of Frederiksen (1980c); part of section 1 of this paper.

5. Section 3 of Frederiksen (1980c); part of section 1 of this paper.

6. Section 4 of Frederiksen (1980c); part of section 1 of this paper.

7. Section 5 of Frederiksen (1980c); part of section 1 of this paper.

8. Section 6 of Frederiksen (1980c); part of section 2A of this paper.

9. Samples R1506A, B of section 2B.

10. Sample R2353 (fig. 13); also, section 9 of Frederiksen (1980c), part of section 2A of this paper.

11. Samples R1507A, B of section 2B.

12. Section 7 of Frederiksen (1980c); part of section $2 A$ of this paper.

13. Section 8 of Frederiksen (1980c); part of section $2 A$ of this paper.

14. Section 10 of Frederiksen (1980c); part of section $2 \mathrm{~A}$ of this paper.

15. Sample R1523 of section 4.

16. Little Stave Creek, sample series R2082 I-T and UCR 8069-8100, section 3B; also, section 3A (=section 11 of Frederiksen, $1980 \mathrm{c}$ ).

17. Sample R2080A of section 4.

18. Sample R2587B (photographed specimen).

19. Sample R2085F of section 4.

20. Sample R3236 of section 4.

21. Samples R2663C, D of section 4.

22. Samples R2034B, C of section 4.

23. Sample R2031 of section 4 .

24. Sample R2032 of section 4

25. Corehole 99 of Gibson and Bybell (1981) and coreholes C166G and C167G of Bybell and Gibson (1985), used to obtain standard thicknesses for the Bashi and Tallahatta Formations for figure 5.

26. Sample R1138A (photographed specimens).

27. Samples R2182B and R2274 of section 4.

28. Albany core, samples AC $256^{\prime}-586^{\prime}$, section 5 . 
in most of the sections were already known and tentative formation boundaries in the Albany core had been picked. Furthermore, I had only relatively few samples from several of the studied sections. Therefore, a main objective in drawing graphic correlation diagrams in this paper was to determine whether the sporomorph range data supported the previously drawn positions of the formation boundaries. A second main objective of the graphic correlation diagrams was to enable compositing of the range bases and tops of the sporomorph taxa, finishing with the composite standard section (pl. 17, in pocket). Again, I emphasize that the compositing process depended mainly on lines of correlation that had been drawn primarily on the basis of known positions of the formation boundaries.

In table 1, OTU's are given odd number designations; in the graphic correlation charts, range bases are identified by the OTU number and range tops are identified by the next higher integer than the OTU number. For example, Nuxpollenites crockettensis is OTU 237; the range base of this OTU in any particular section is event 237, and the range top of the OTU is event 238. A range base data point is marked by the symbol $O$, a range top data point by + .

\section{SAMPLE REGISTER}

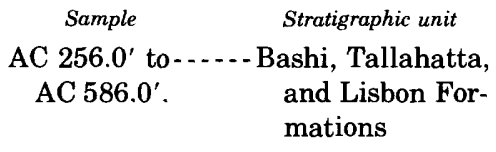

R1138A ........ Tallahatta Forma-

R1155-........-Zilpha Clay

Remarks
Albany core, lat
$31^{\circ} 31^{\prime} 05^{\prime \prime}$ N., long
$84^{\circ} 06^{\prime} 42^{\prime \prime}$ W., Albany
East $7.5^{\prime}$ quadrangle,
Dougherty County, Ga.
(fig. 2 , loc. 28 ). Eleva-
tion of land surface
195 ft. For sample
data, see table 3.
Factory Creek at road
bridge, lat $31^{\circ} 26^{\prime} 04^{\prime \prime}$
N., long $85^{\circ} 02^{\prime} 48^{\prime \prime}$ W.,
Columbia NE. quad-
rangle, Early County,
Ga. (fig. 2, loc. 26 ).
Stop 8, bed 5 of
Marsalis and Friddell
(1975). Medium-gray
fine- to medium-
grained silty sand. Col-
lected by N.O. Fred-
eriksen; field no. G-30.
Outcrop at Tocowa, SE1/4
sec. 8 , T. 10 S., R. 8
W., Tocowa $7.5^{\prime}$ quad-
rangle, Panola County,
Miss. (fig. 2, loc. $2 ;$ see
Vestal, 1956, p. $61-63$,
$142-144$ ). Lignite; col-
lected by R.S. Young.

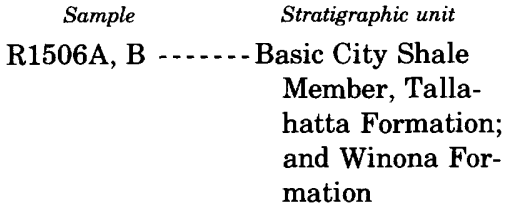

R1507A, B ......-Basic City Shale Member, Tallahatta Formation

Remarks
Mississippi Geological Survey corehole AN$60, \mathrm{SW}^{1 / 4} \mathrm{SE}^{1 / 4 \mathrm{NW}^{1} / 4}$ sec. 2, T. 4 N., R. 14 E., Enterprise 15' quadrangle, Clarke County, Miss. (fig. 2, loc. 9; see Gilliland, 1980 , p. 139, 140). Sample A is from 24.0-24.5 ft depth; medium-dark-gray mudstone and lightgray fine-grained sandstone; uppermost Tallahatta Formation. Sample B is from 20.0$20.5 \mathrm{ft}$ depth; darkgray clayey finegrained sandstone; lower part of the Winona Formation. The Tallahatta-Winona contact is at $24 \mathrm{ft}$ depth. Collected by W.A. Gilliland.

Mississippi Geological Survey corehole AN$59, \mathrm{NW}^{1 / 4} \mathrm{SE}^{1 / 4 \mathrm{NW}^{1 / 4}}$ sec. 6, T. 4 N., R. 17 E., Quitman $15^{\prime}$ quadrangle, Clarke County, Miss. (fig. 2, loc. 11; see Gilliland, 1980, p. 139). Sample A is from $30.5-31.0 \mathrm{ft}$ depth; medium-olivegray shale. Sample B is from $23.5-24.0 \mathrm{ft}$ depth; medium-olivegray shale. The base of the Basic City Shale Member in this core is at $76.0 \mathrm{ft}$. Collected by W.A. Gilliland.

R1523-........ Bashi Formation
Roadcut on east side of State Highway 69, 3.5 $\mathrm{mi}$ south of MarengoClarke County line, 0.2 mi south of bridge over Bashi Creek, sec. 9, T. 11 N., R. 1 E., Morvin 7.5' quadrangle, Clarke County, Ala. (fig. 2, loc. 15). Alternate type locality of the Bashi Formation; $4 \mathrm{ft}$ below the lower indurated bed of the Bashi; mediumgreenish-gray bioturbated glauconitic sand. Collected by C.C. Smith; field no. 27-3. 

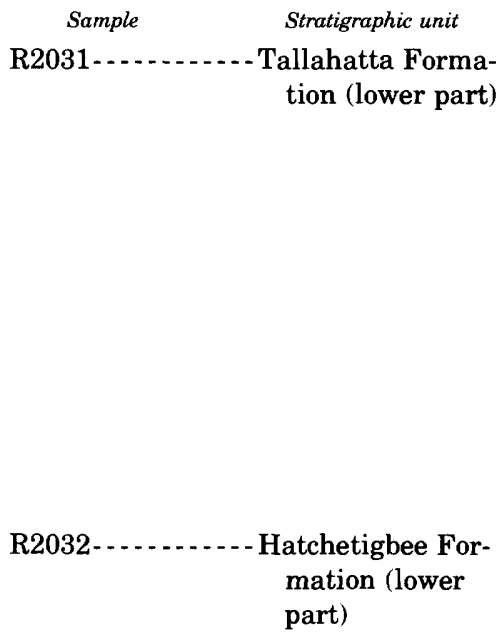

R2034B, C.......- Hatchetigbee Formation (middle and upper parts)

R2080A - . . . . . . Tallahatta Formation
Remarks
Small roadcut at northwest corner of road intersection, along small creek, $20 \mathrm{ft}$ south of BM 337 , lat $31^{\circ} 29^{\prime} 05^{\prime \prime}$ $\mathrm{N}$., long $85^{\circ} 16^{\prime} 10^{\prime \prime} \mathrm{W}$., sec. 18 , T. 6 N., R. 28 E., Newville 7.5' quadrangle, Henry County, Ala. (fig. 2, loc. 23). Collected by T.G. Gibson; field no. C87A-1; medium-gray, carbonaceous clay.

Roadcut on north side of road, $1,000 \mathrm{ft}$ west of Abbie Creek, lat $31^{\circ} 28^{\prime} 40^{\prime \prime}$ N., long $85^{\circ} 14^{\prime} 40^{\prime \prime}$ W., sec. 21 , T. 6 N., R. 28 E., Haleburg 7.5' quadrangle, Henry County, Ala.

(fig. 2, loc. 24). Collected by T.G. Gibson; field no. C86A-1; medium-dark-grayishbrown micaceous mudstone.

Roadcut $500 \mathrm{ft}$ east of bridge over

Choctawhatchee River on Highway 27, lat $31^{\circ} 29^{\prime} 45^{\prime \prime}$ N., long $85^{\circ} 21^{\prime} 50^{\prime \prime}$ W., sec. 17 , T. 6 N., R. 27 E., Newville 7.5' quadrangle, Henry County, Ala. (fig. 2, loc. 22 ; Gibson, 1980, fig. 11, sec. 89). Collected by T.G. Gibson. Field no. C89A-3 (R2034B; middle part of formation), medium-grayish-brown silty glauconitic clay; C89A-5 (R2034C; uppermost part of formation), light-brownishgray silty glauconitic weathered clay.

West bank of the Alabama River at Lisbon Landing, $\mathrm{SE}^{1 / 4}$ sec. 3 and NW1/4 sec. 11 , T. 7 N., R. 5 E., Claiborne 7.5' quadrangle, Monroe County, Ala. (fig. 2, loc. 17). Sample is from $3 \mathrm{ft}$ below the top of the formation. Collected by J.E. Hazel, L.E. Edwards, and L.W. Ward; field no. 79-JHA-170.
Sample R2082 I, K, . . . . - - Lisbon Formation $\mathrm{L}, \mathrm{M}, \mathrm{T}$.

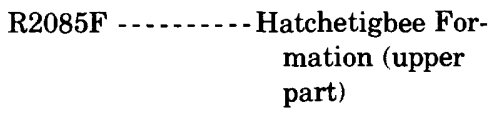

R2182B - . . . Hatchetigbee Formation (upper part)
R2274-... . . . . . Tallahatta Forma- tion (lowermost part)

R2353-......... . Dobys Bluff Tongue (of Dockery, 1980) of the Kosciusko Formation (of Thomas, 1942; Sparta Sand of U.S. Geological Survey usage)
Remarks
Little Stave Creek, approximately $3.5 \mathrm{mi}$ north of Jackson, in sections $19,20,21$, T. 7 N., R. 2 E., Jackson 7.5' quadrangle, Clarke County, Ala. (fig. 2, loc. 16). Samples of the R2082 series were collected during a field trip in 1979 led by J.E. Hazel and were recorded with respect to sample locations of Bandy (1949); positions of the samples are shown in figure 4.

North end of railroad tunnel at Tunnel Springs, NW $1 / 4$ sec. 13 , T. 8 N., R. 8 E., Beatrice 7.5' quadrangle, Monroe County, Ala. (fig. 2, loc. 19; Scott, 1972, p. 3; Gibson and Bybell, 1981, p. 305). Collected by J.E. Hazel and L.E. Edwards; field no. 79JHA-95; mediumdark-gray silty micaceous shale $9 \mathrm{ft}$ above base of outcrop.

Greens Branch just north of Highway 266, lat $31^{\circ} 40^{\prime} 13^{\prime \prime}$ N., long $84^{\circ} 54^{\prime} 57^{\prime \prime}$ W., Coleman 7.5' quadrangle, Randolph County, Ga. (fig. 2, loc. 27; unit 8 of Reinhardt and Gibson, 1980, fig. 47). Collected by T.G. Gibson; field no. C122G-3.

Same locality as R2182B. Collected by T.G. Gibson; field no. C122G-2 (unit 9 of Reinhardt and Gibson, 1980, fig. 47).

Dobys Bluff, east side of the Chickasawhay River; center of north line, $\mathrm{NW}^{1 / 4} \mathrm{SW}^{1 / 4} \mathrm{NW}^{1 / 4}$ sec. 18 , T. 2 N., R. 16 E., Quitman $15^{\prime}$ quadrangle, Clarke County, Miss. (fig. 2, loc. 10). "Sand, gray, very fossiliferous" unit $11.5 \mathrm{ft}$ below the base of the Cook Mountain Formation (Dockery, 1980, 


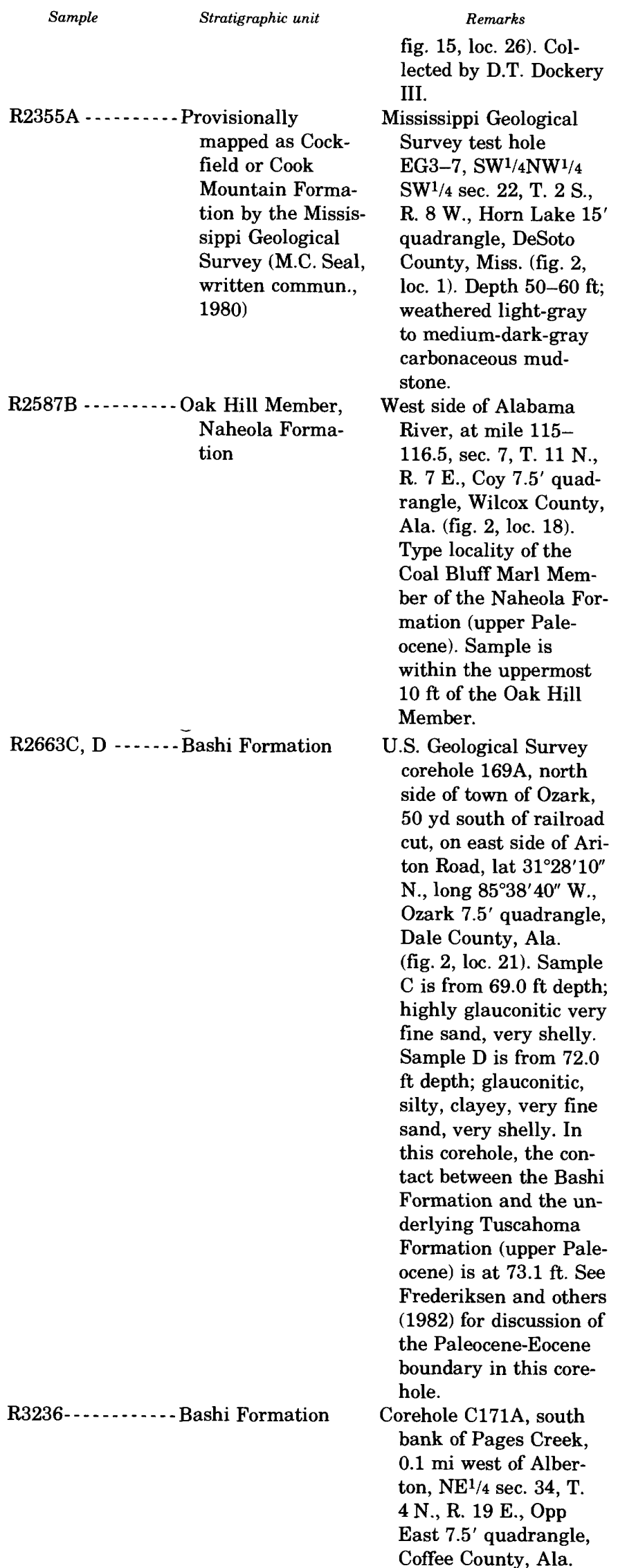

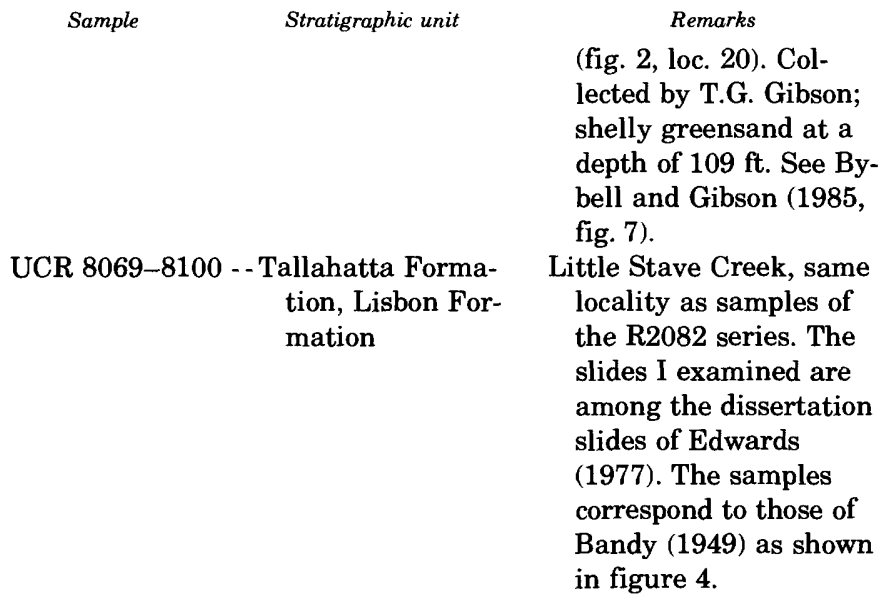

\section{BIOSTRATIGRAPHY AND CORRELATION}

Many papers on Eocene sporomorphs of the Atlantic and Gulf Coastal Plains have been published, but range charts for the entire Eocene (of the Gulf Coast) have been presented only by Tschudy $(1973,1975)$ and by Elsik (1974a) and Elsik and Dilcher (1974). Tschudy showed ranges of taxa, many of which were at the rank of species or species group. Elsik (1974a) and Elsik and Dilcher (1974) indicated ranges of taxa mainly of generic rank. Table 2 compares the numbers of total operational taxonomic units (OTU's), range bases, and range tops shown for the Eocene of the Gulf Coast by these authors and in this paper. The table shows that this paper deals with approximately 3.5 times as many Eocene taxa as did Tschudy and about 6 times as many taxa as did Elsik. More significantly from the point of view of biostratigraphic resolution, the present paper indicates the positions of about 4 to 6 times as many range tops and bases as either of the previous studies; thus, Eocene samples of uncertain stratigraphic position can now be much more accurately correlated with formations or even with parts of formations than was previously possible.

One of the main objectives of this paper is to create a composite standard sporomorph-stratigraphic section for the Eocene of the eastern Gulf Coast. Data for the composite are from five sections in Mississippi, Alabama, and western Georgia, shown in figure 1. The Little Stave Creek section in western Alabama (section 3) was chosen as the standard reference section, and compositing by means of graphic correlation was performed in the following way:

1. Section 4 was composited with section 5

2. Section $3 \mathrm{~B}$ was composited with composite section (CS) $4+5$

3. Section $2 B$ was composited with $\mathrm{CS} 3 \mathrm{~B}+4+5$

4. Section $2 \mathrm{~A}$ was composited with section $3 \mathrm{~A}$ 
TABLE 2.-Comparison of numbers of operational taxonomic units (OTU's) whose ranges in the Eocene of the Gulf Coast are shown in different publications, and numbers of range bases and tops indicated as occurring within the Eocene or at the base or top of this series

[Table assumes that the top of the Eocene coincides with the top of the Jacksonian Stage]

\begin{tabular}{lccc}
\hline \multicolumn{1}{c}{ Publication } & Number of OTU's & $\begin{array}{r}\text { Number of } \\
\text { range bases }\end{array}$ & $\begin{array}{r}\text { Number of } \\
\text { range tops }\end{array}$ \\
\hline Tschudy (1973, 1975) & & 23 & 25 \\
Elsik (1974a); Elsik and Dilcher & & & \\
$\quad(1974)$ & 14 & 19 \\
This paper (fig. 14; pl. 17) & 111 & 91 \\
\hline
\end{tabular}

5. $\mathrm{CS} 2 \mathrm{~A}+3 \mathrm{~A}$ was composited with section 1

6. $\mathrm{CS} 2 \mathrm{~B}+3 \mathrm{~B}+4+5$ was combined with $\mathrm{CS} 1+2 \mathrm{~A}+3 \mathrm{~A}$.

One reason for choosing the Little Stave Creek section (section 3) as the standard reference section was that it includes the entire Eocene sequence of this area except the Bashi-Hatchetigbee interval ${ }^{1}$ and the lower part of the Tallahatta Formation. Furthermore, the formations at this locality have been described in detail (Smith and others, 1944; Bandy, 1949; Toulmin, 1962), the paleontology of the sequence is better known than that of any other equivalent section in the Gulf Coast, and I have far more samples from Little Stave Creek than from any other section in the eastern Gulf Coast.

The Little Stave Creek section in Clarke County, Ala. (fig. 2, loc. 16) is on the upthrown side of the Jackson fault and is about 6-25 mi southwest (downdip) of the normal Eocene outcrop belt in the region. The thicknesses of the lowest Eocene formations in the Little Stave Creek area are uncertain because the BashiHatchetigbee interval and the lower part of the Tallahatta Formation have been cut out there by the Jackson fault (fig. 1). Sixty-seven $\mathrm{ft}$ of the Tallahatta Formation are preserved at Little Stave Creek. However, the Tallahatta is a maximum of $200 \mathrm{ft}$ thick in Alabama (Toulmin, 1944). In the outcrop belt of northwestern Monroe County, just to the east of Clarke County, the formation is $100 \mathrm{ft}$ thick and "thickens rapidly downdip and westward" (Scott, 1972, p. 3). In the shallow subsurface of central Monroe County, the Tallahatta is at least $170 \mathrm{ft}$ thick (hole C178A of Bybell

\footnotetext{
1The U.S. Geological Survey (U.S.G.S.) considers the Bashi and Hatchetigbee to be separate formations. Furthermore, the U.S.G.S. considers the Bashi to include most marine strata within the Bashi-Hatchetigbee interval and the Bashi to be, generally speaking, the downdip equivalent of the Hatchetigbee (Gibson and Bybell, 1981; Gibson, 1982). However, this usage is opposed by some Gulf Coast geologists (Dockery and others, 1984), who prefer the traditional concept that the term "Bashi" should be restricted to a high-resistivity, concretionary, fossiliferous marine unit that, at least updip, is immediately overlain by unfossiliferous Hatchetigbee strata. In this view, the Bashi is either an independent formation underlying the Hatchetigbee Formation or is a member forming the base of the Hatchetigbee. In this paper, I have generally followed Gibson's (1982) concept that thick sequences of nonmarine strata are the Hatchetigbee Formation and sequences of marine strata are the Bashi Formation. However, where these two facies interfinger, or are undifferentiated, refer to these strata collectively as the Bashi and Hatchetigbee Formations or as the BashiHatchetigbee interval.
}

and Gibson, 1985). Therefore, I assume a thickness of $180 \mathrm{ft}$ for the total thickness of the Tallahatta Formation in the Little Stave Creek area.

The combined Bashi and Hatchetigbee Formations are 250-300 ft thick in southwestern Alabama (Causey and Newton, 1972). However, in the composite standard section (pl. 17, in pocket), I did not want to show these formations being, say, 275 composite standard units thick because these units would each represent far less geologic time than composite standard units for the other Eocene formations. In section 4, I assigned a thickness to the Bashi and Hatchetigbee that depended on the ratio of the thickness of the Bashi-Hatchetigbee interval to the Tallahatta near the Alabama-Georgia border (see description of section 4). I used the same thickness ratio, and the presumptive thickness of 180 composite standard units for the entire Tallahatta in the Little Stave Creek area, to assign a thickness of 67 units to the Bashi-Hatchetigbee in the composite standard section. Above the Tallahatta, the Eocene section at Little Stave Creek is $263 \mathrm{ft}$ thick; therefore, the full thickness of the Eocene in the composite standard section is 510 composite standard units (assuming for the moment that the Jacksonian-Vicksburgian Stage boundary coincides with the Eocene-Oligocene boundary).

\section{SECTIONS 2B, 3B, 4, 5}

SECTION 2B

This composite section (figs. 1,3) includes five samples from the lower and middle Claibornian Stage of eastern Mississippi. Because the samples are all from Clarke County, Miss., the geology of which has been studied in detail (Gilliland, 1980), it was not difficult to place them in an approximate standard thickness scale. Samples R1507A and B and R1506A are all from cores in the Basic City Shale Member of the Tallahatta Formation. Sample R1506B is from a core in the lower part of the Winona Formation, which overlies the Tallahatta. The fifth sample, R2353, is from the outcropping Dobys Bluff Tongue (of Dockery, 1980) of the Kosciusko Formation (of Thomas, 1942; Sparta Sand of U.S. Geological Survey usage). Information on the stratigraphy of the samples follows, and additional data on the localities are given in the "Sample Register."

\section{SAMPLES R1507A, B}

These samples are from the Basic City Shale Member of the Tallahatta Formation (fig. 2, loc. 11). They are from $45 \mathrm{ft}$ and $52 \mathrm{ft}$, respectively, above the base of the member in this corehole. The Basic City is generally about $100-125 \mathrm{ft}$ thick in this area (Gilliland, 1980, p. 37); thus, the samples are from the middle of the 

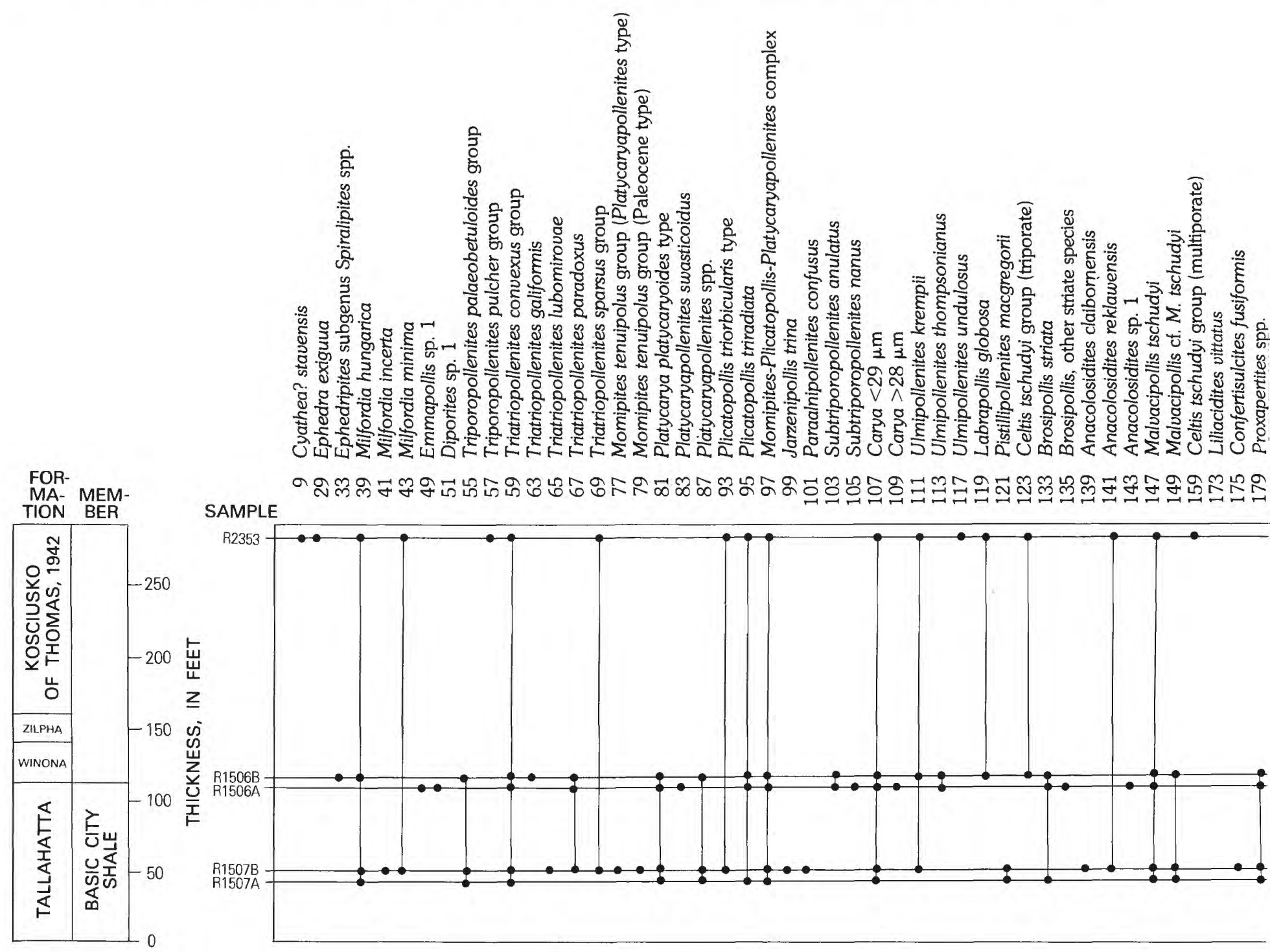

\section{SAMPLE}

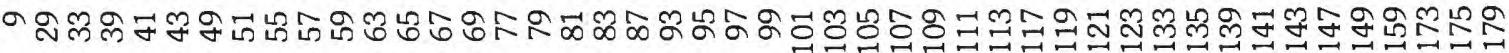

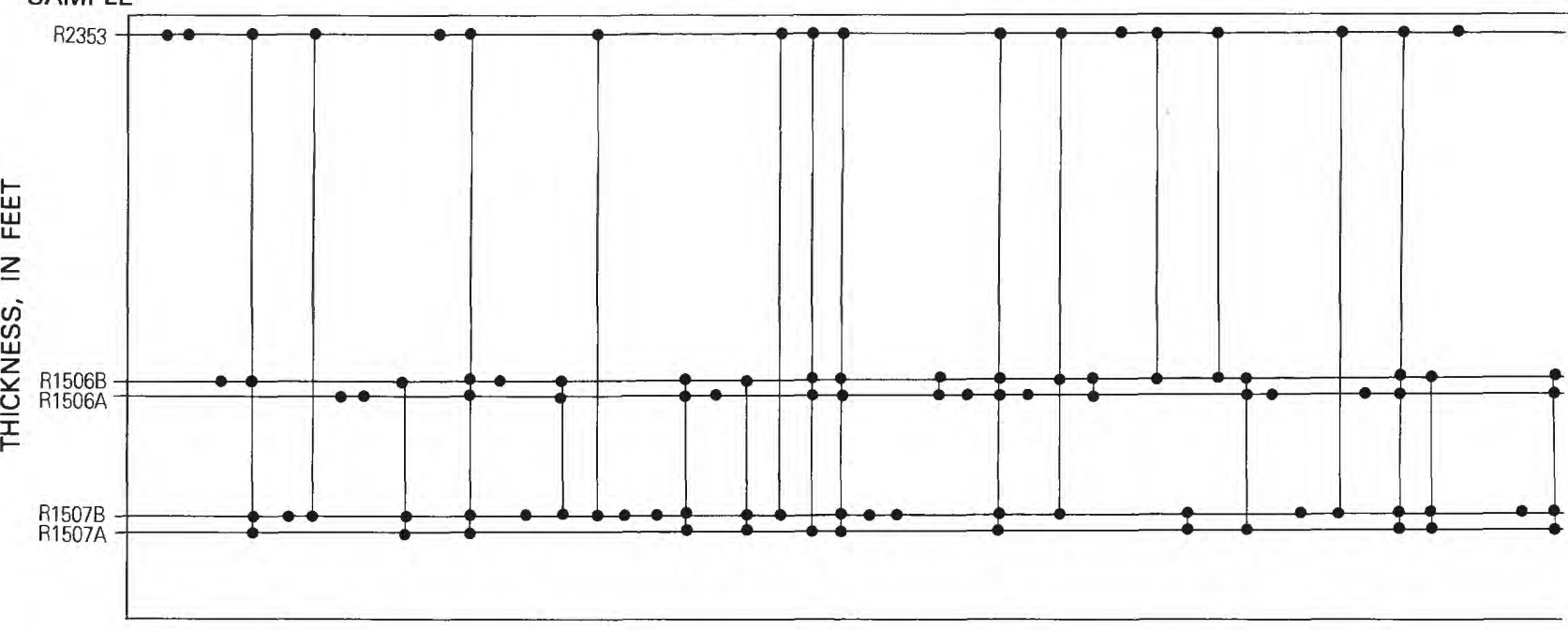

FiguRE 3.-Occurrences and local ranges of

member. Below the Basic City Shale Member is the Meridian Sand Member of the Tallahatta, $27 \mathrm{ft}$ thick in this corehole. If the Meridian corresponds to lower Tallahatta strata in Alabama and Georgia, which belong to calcareous nannofossil Zone NP12 (Bybell and Gibson, 1985), then the present samples should belong to NP13 and (or) NP14.

\section{SAMPLE R1506A}

This sample is from the top of the Basic City Shale Member (fig. 2, loc. 9). In much of the Eocene outcrop belt in Mississippi, the Neshoba Sand Member forms the upper part of the Tallahatta, but this member ap- pears to be missing in easternmost Mississippi (Gilliland, 1980, p. 39); thus, the present sample is from the top of the Tallahatta Formation. The corehole from which the sample was taken is 4.2 mi west of the stratotype locality for the Basic City Shale Member.

\section{SAMPLE R1506B}

This sample is from the lower part of the Winona Formation (fig. 2, loc. 9). The Winona Formation of Mississippi has been correlated with the lower part of the Lisbon Formation of Alabama by Fisher (1964) and Toulmin (1977). On lithologic and faunal criteria, Dockery $(1980$, p. 32$)$ correlated the Winona of Clarke 


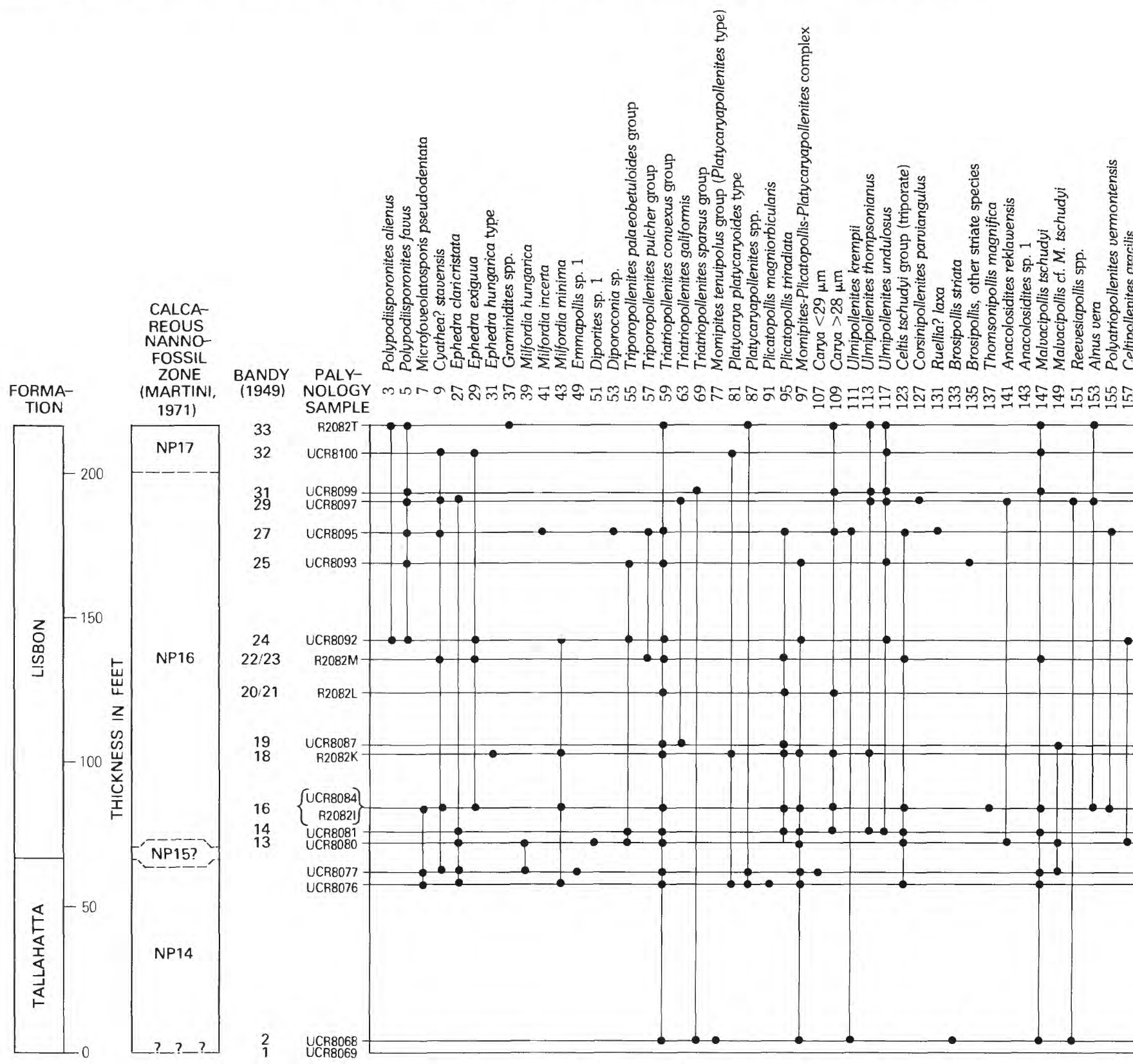

FIGURE 4.-Occurrences and local ranges o

occurrences and ranges of sporomorph OTU's in the samples, are shown in figure 4 . Section $3 \mathrm{~A}$, which had previously been analyzed for sporomorphs (Frederiksen, 1969, 1973, 1980c), extends from the Gosport Formation to the top of the Yazoo Clay (fig. 1).

\section{SECTION 4}

This section is a composite that includes 12 samples from Alabama and western Georgia: 4 samples from the Bashi Formation, 5 from the Hatchetigbee Formation, and 3 from the Tallahatta Formation (figs. 1, 5).
Where outcrops of these formations can be dated using calcareous nannofossils, they always belong to Zone NP10, the lowest zone of the Eocene (Gibson and Bybell, 1981).

Some of my samples were from uncertain stratigraphic positions within the Bashi or Hatchetigbee. Therefore, a composite section could not be drawn in which all the samples could be accurately placed relative to one another, and I have lumped most of these analyses together for purposes of the palynological section (fig. 5) and arbitrarily considered this composite 


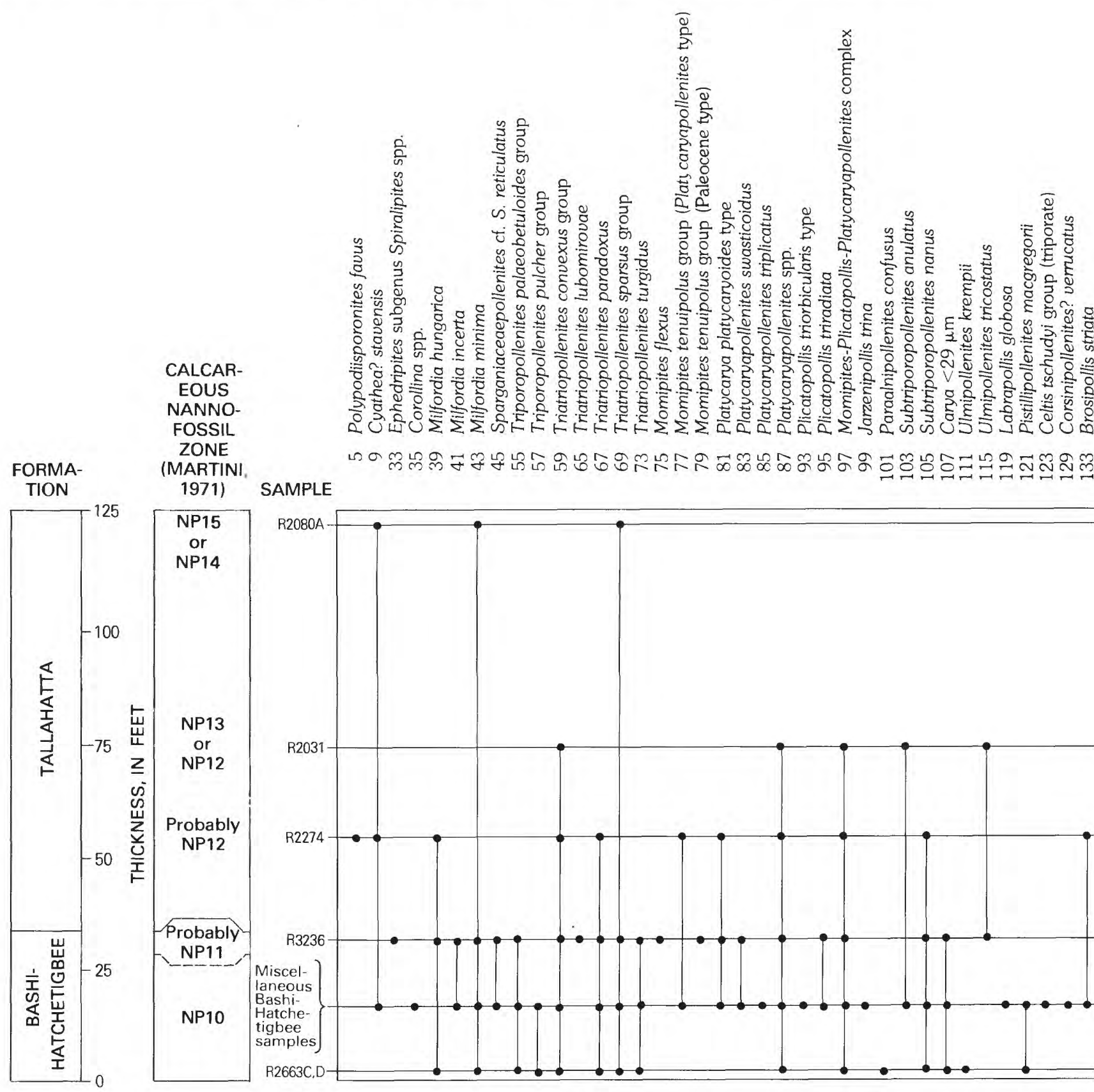

FIGURE 5.-Occurrences and local ranges of operational taxonomic units in section 4. Thicknesses

loc. 20). A sample 3 in lower in the core has been assigned to either calcareous nannofossil Zone NP10 or NP11 but most probably belongs to NP11 (Bybell, oral commun., 1984; Bybell and Gibson, 1985, fig. 7). Thus, this sample is younger than any known outcropping strata of the Bashi or Hatchetigbee.

Section 4 includes three samples from the Tallahatta Formation in Alabama and Georgia. In descending stratigraphic order, these samples are as follows (see "Sample Register" for details; calcareous nannofossil zones are from T.G. Gibson and L.M. Bybell, oral commun., 1984):

R2080A-3 ft below top of formation; probably NP14, but possibly NP15; western Alabama (fig. 2, loc. 17) R2031-Lower part of formation, probably the updip correlative of NP12 or possibly the lower part of NP13; eastern Alabama (fig. 2, loc. 23)

R2274-4 $\mathrm{ft}$ above base of formation; probably the updip correlative of NP12; western Georgia (fig. 2, loc. 27) 

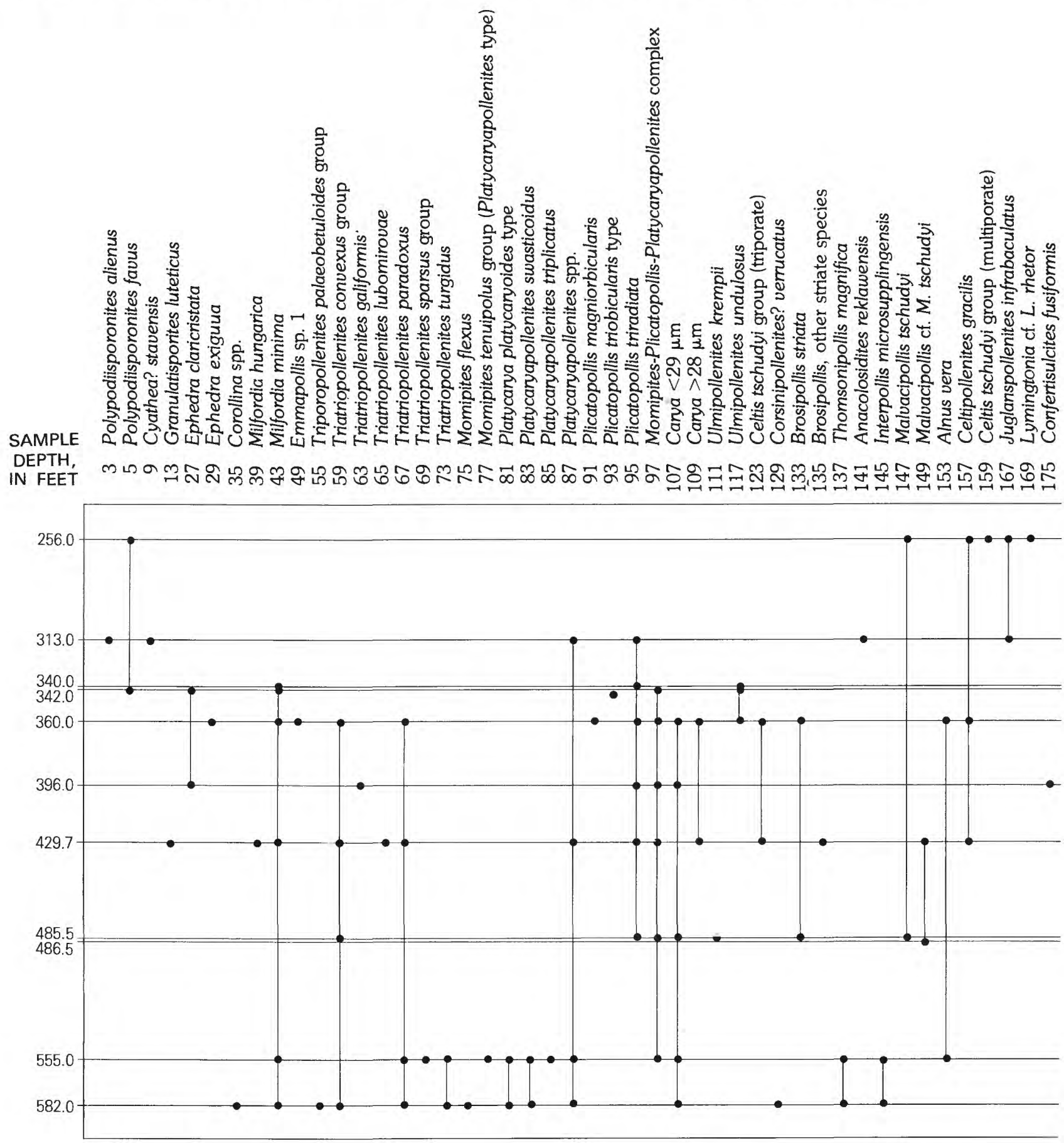

FIGURE 6.-Occurrences and local ranges of

SECTION 5

These samples are from a continuous core from the Albany well in the Albany East 7.5' quadrangle, Dougherty County, southwestern Georgia (fig. 2, loc. 28). This well was drilled in 1977 by the U.S. Army Corps of Engineers under contract to the U.S. Geologi- cal Survey. The first core was taken at a depth of $79 \mathrm{ft}$ in deeply weathered carbonate rock probably of the Ocala Limestone (Jacksonian Stage), and the well reached a total depth of $1,076 \mathrm{ft}$, bottoming in the Cusseta Sand (Campanian; J. Reinhardt, oral commun., 1984). The well section is largely of carbonate rock, and only 12 samples containing good sporomorph assem- 
TABLE 3.-Lithologic divisions, tentative formation assignments, and samples from the Albany core (section 5) [Lithologic divisions from J. Reinhardt (written commun., 1978); formation assignments from T.G. Gibson, oral commun., 1978]

\begin{tabular}{|c|c|c|}
\hline Lithology & $\begin{array}{l}\text { Tentative formation } \\
\text { assiggment }\end{array}$ & $\begin{array}{l}\text { Sample depth } \\
\text { (feet) }\end{array}$ \\
\hline 0-239-1imestone & Ocala and Jackson & \\
\hline 239 & Lisbon & $\begin{array}{l}256.0 \\
313.0 \\
340.0 \\
342.0 \\
360.0 \\
396.0\end{array}$ \\
\hline 401-538 & Tallahatta & $\begin{array}{l}429.7 \\
485.5 \\
486.5\end{array}$ \\
\hline $538-585-$ Limestone, sandstone, and claystone & Bashi & $\begin{array}{l}555.0 \\
582.0 \\
586.0\end{array}$ \\
\hline $585-710$ & Tuscahoma & \\
\hline
\end{tabular}

samples are available from these units in the Albany core (section 5). However, in figure 7, I hoped (1) to find evidence that would support or disprove the lithologic pick of the Bashi-Tallahatta boundary at $538 \mathrm{ft}$ depth in the Albany core (table 3; dot enclosed by a triangle in fig. 7) and (2) to determine whether I could correlate the Tallahatta samples of the core with samples in section $\mathbf{4}$ for which the calcareous nannofossil zones were known.

The Paleocene-Eocene boundary in the Albany core was tentatively picked at $585.0 \mathrm{ft}$ depth on the basis of lithology (table 3). However, a sample from $586.0 \mathrm{ft}$ (not shown in fig. 6) contained a small assemblage that included the late Sabinian (early Eocene) forms Platycarya platycaryoides type (OTU 81), Platycaryapollenites swasticoidus (83), Platycaryapollenites triplicatus (85), and Interpollis microsupplingensis (145), mixed with Momipites flexus (OTU 75) and Momipites strictus Frederiksen \& Christopher 1978, both of which may be reworked from the upper Paleocene. The next lower samples are from $603.0 \mathrm{ft}$ and $611.5 \mathrm{ft}$ (not shown in fig. 6). These samples contain sparse sporomorph assemblages that include the early Eocene OTU's Platycarya platycaryoides type and Interpollis microsupplingensis. The next lower sample is from $651.5 \mathrm{ft}$; this sample also contains a sparse assemblage which, however, lacks any sporomorphs that are confined to the Eocene or Paleocene as far as I know. Thus, the Paleocene-Eocene boundary in the core is below, but (because of reworked Paleocene forms) perhaps not far below, $611.5 \mathrm{ft}$. The lowest sample I have examined from the core is from $685.5 \mathrm{ft}$ depth and is late Paleocene in age.

Sixty-seven OTU's are common to sections 4 and 5; thus, 134 events (range bases and tops) might be useful for correlation between the two sections. However, 23 of the OTU's are known to range down into the Paleocene, and 54 of them range up into the Lisbon Formation or its equivalents; thus, 44 range bases and 13 range tops remain for use in the correlation diagram. Among the 44 range bases of OTU's not known to range down into the Paleocene, 14 had to be discarded because the range bases of these OTU's were at levels higher than $429.7 \mathrm{ft}$ in the Albany core. Thus, by elimination, figure 7 includes 30 range bases and 13 range tops.

Five of the OTU's in sections 4 and 5 are probably or possibly there only as specimens reworked from the Paleocene. These OTU's are Ephedripites subgenus Spiralipites spp. (33), Corollina spp. (35), Retitrescolpites anguloluminosus (203), Momipites flexus (75), and Paraalnipollenites confusus (101). The first three of these range down at least into the Cretaceous; all five are well known to range at least to the top of the Paleocene. Aside from sparse, scattered occurrences in the Claibornian and Jacksonian stages, almost certainly as reworked specimens, all these OTU's are confined to the upper Sabinian Stage if found at all in the Eocene. Probably it is impossible to determine for certain whether the plants producing these pollen grains still lived on the Gulf Coast in late Sabinian time; whether they are actually reworked or not, these OTU's are of subordinate importance as markers for the upper Sabinian Stage.

It seems clear that the Albany core samples from 582.0 and $555.0 \mathrm{ft}$ depth correlate with the BashiHatchetigbee interval of section 4 . The large number of range bases and tops in the "middle sample" (actually a composite of six samples) from the BashiHatchetigbee interval of section 4 is misleading; in- 
spection of figure 5 shows that many OTU's range through all three sample levels of the BashiHatchetigbee in section 4 and that the "middle sample" contains many OTU's that were found only in that one "sample."

In order to upgrade the data, I went back to the occurrence-range charts for sections 4 and 5 (figs. 5,6 ) and tried to rate the quality of each observed range base and top in each section. Abrupt first or last occurrences of OTU's found consistently in samples throughout their ranges were judged most likely to be high-quality events, for example, in section 4 (fig. 5), the range bases of Malvacipollis tschudyi (OTU 147) and Lanagiopollis hadrodictya (299) and the range tops of Triatriopollenites paradoxus (67) and Triatriopollenites turgidus (73). Range tops near the base of the Eocene might also be given high rankings, based on occurrences in only one or two Eocene samples, if it was thought that these occurrences were at or near the true range tops of the OTU's, for example (in fig. 6) events 130 (Corsinipollenites verrucatus) and 324 (Intratriporopollenites pseudinstructus group). Highest quality events were ranked 1, somewhat lesser quality events were ranked 2 , and so on. I ranked the events in each section separately and then added the two rankings for each OTU, as shown in table 4.

Figure 8 is a graphic correlation chart of sections 4 and 5 but showing only summed rankings of presumed high-quality events. An interesting feature of table 4 and figure 8 is that the events in the "middle sample" from the Bashi-Hatchetigbee are generally not of very high quality, mainly because, as just noted, most of these events represent the only occurrences of the OTU's in this section. Ranking the events in figure 8 thus eliminates some of these more or less spurious events that appeared important in figure 7.

However, several groups of apparently high-quality events do exist in figure 8:

1. Range bases of three OTU's are in the lowest samples of the Bashi-Hatchetigbee in both sections; these OTU's are Triatriopollenites paradoxus (67), Triatriopollenites turgidus (73), and Interpollis microsupplingensis (145). However, this data point does not lie on the line of correlation because I have no good samples between the sample from $582.0 \mathrm{ft}$ and the base of the Bashi Formation in the Albany core.

2. Range tops of four OTU's are present in the uppermost sample from the Bashi-Hatchetigbee in section 4 (R3236) and also in the Albany core sample from $555.0 \mathrm{ft}$ depth. These OTU's are 73 (Triatriopollenites turgidus), 83 (Platycaryapollenites swasticoidus), 137 (Thomsonipollis magnifica), and 145 (Interpollis microsupplingensis). On the
TABLE 4.-Initial ranking of presumed high-quality events in sections 4 and 5

\begin{tabular}{|c|c|c|}
\hline Section 4 & Section 5 & Total \\
\hline $67 \ldots 1$ & 1 & 2 \\
\hline 73 & 1 & 2 \\
\hline 77 & 2 & 4 \\
\hline 81 & 1 & 3 \\
\hline $83-2$ & 1 & 3 \\
\hline 85 & 2 & 4 \\
\hline 97 & 1 & 3 \\
\hline 323 & 2 & 5 \\
\hline $133 \ldots 2$ & 2 & 4 \\
\hline 145 & 1 & 2 \\
\hline 147 & 3 & 4 \\
\hline 149 & 1 & 2 \\
\hline 157 & 1 & 4 \\
\hline 199 & 2 & 4 \\
\hline 221 & 2 & 4 \\
\hline $223-2$ & 1 & 3 \\
\hline 239 & 2 & 4 \\
\hline 247 & 1 & 4 \\
\hline 295 & 3 & 4 \\
\hline 297 & 2 & 3 \\
\hline 299 & 1 & 2 \\
\hline $317 \ldots$ & 2 & 5 \\
\hline 74 & 1 & 2 \\
\hline 76 & 1 & 4 \\
\hline 78 & 2 & 3 \\
\hline 84 & 1 & 2 \\
\hline $86 \ldots 2$ & 2 & 4 \\
\hline $130 \ldots 2$ & 2 & 4 \\
\hline 138 & 1 & 2 \\
\hline 146 & 1 & 2 \\
\hline 198 & 2 & 3 \\
\hline 206 & 2 & 4 \\
\hline $244 \ldots 1$ & 2 & 3 \\
\hline 294 & 3 & 4 \\
\hline $318 \ldots 2$ & 1 & 3 \\
\hline
\end{tabular}

basis of lithologic evidence, the Bashi-Tallahatta boundary in the core had been picked at $538 \mathrm{ft}$ depth, and the data points in figure 8 support this general placement.

3. Range bases of five OTU's are in the lowest sample from the Tallahatta Formation of section 4 (R2274) and in the Albany core samples from $486.5 \mathrm{ft}$ and $485.5 \mathrm{ft}$ depth. The events in the sample from $486.5 \mathrm{ft}$ have rankings of 2 and are for OTU's 149 (Malvacipollis cf. M. tschudyi) and 299 (Lanagiopollis hadrodictya), whereas the events in the sample from $485.5 \mathrm{ft}$ had been thought to have rankings of 3 or 4 and are 147 (Malvacipollis tschudyi), 295 (Lanagiopollis crassa type), and 297 (Lanagiopollis eocaenica type). 


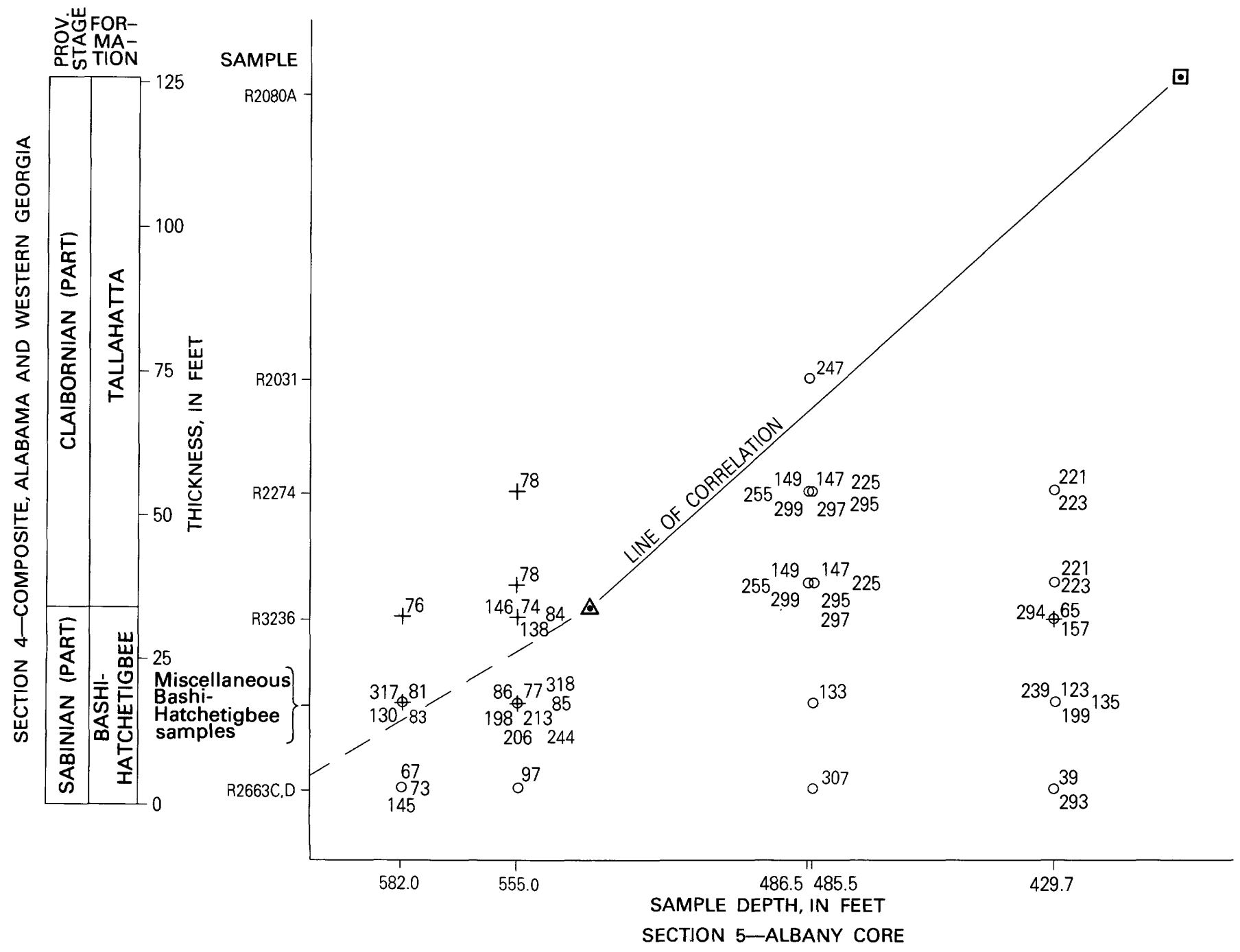

FIGURE 7.-Graphic correlation of sections 4 and 5 showing all events thought to be usable. The dot enclosed by a triangle is the contact between the Bashi-Hatchetigbee interval and the Tallahatta Formation; the dot enclosed by a square is the contact between the Tallahatta and Lisbon Formations. In the Albany core (section 5), these contacts were tentatively picked on the basis of lithology (table 3). The dashed leg of the line of correlation is drawn on the assumption that the Bashi-Hatchetigbee interval in section 4 is $34 \mathrm{ft}$ thick and that the base of the Bashi Formation in the Albany core is at $615 \mathrm{ft}$ depth. Data points are events ( $O=$ range base; $+=$ range top) accompanied by event numbers.
In summary, figure 8 presents evidence from which one can conclude, at least tentatively, that the boundary between the Bashi-Hatchetigbee and Tallahatta is well marked by range bases at the base of the Tallahatta and by range tops at the top of the BashiHatchetigbee. Furthermore, Bashi sample R3236, which is probably from calcareous nannofossil Zone NP11, is distinctly more similar to the other Bashi samples, which belong to NP10, than it is to the lower part of the Tallahatta, which is in NP12.

A distinctive feature of figures 7 and 8 is the near lack of data points in the upper half of each diagram, that is, in samples R2080A (uppermost Tallahatta) and
R2031 (middle of the Tallahatta) of section 4. The fact that no range bases or tops were found in sample $\mathrm{R} 2080 \mathrm{~A}$ is not surprising; this is a sparse sample, containing only six OTU's. Sample R2031 is fairly rich in taxa (20 OTU's; fig. 5). However, of 18 OTU's that appear to have range tops in sample R2031 (fig. 5), 16 of these range elsewhere into the overlying Lisbon Formation; the other 2 are found in section 4 but not in section 5 and therefore are not shown in figures 7 and 8. No OTU's have range bases in sample R2031 except several that were found only in this sample. Furthermore, figure 8 shows that the events in the Albany core sample from $429.7 \mathrm{ft}$ depth (upper part of the Talla- 


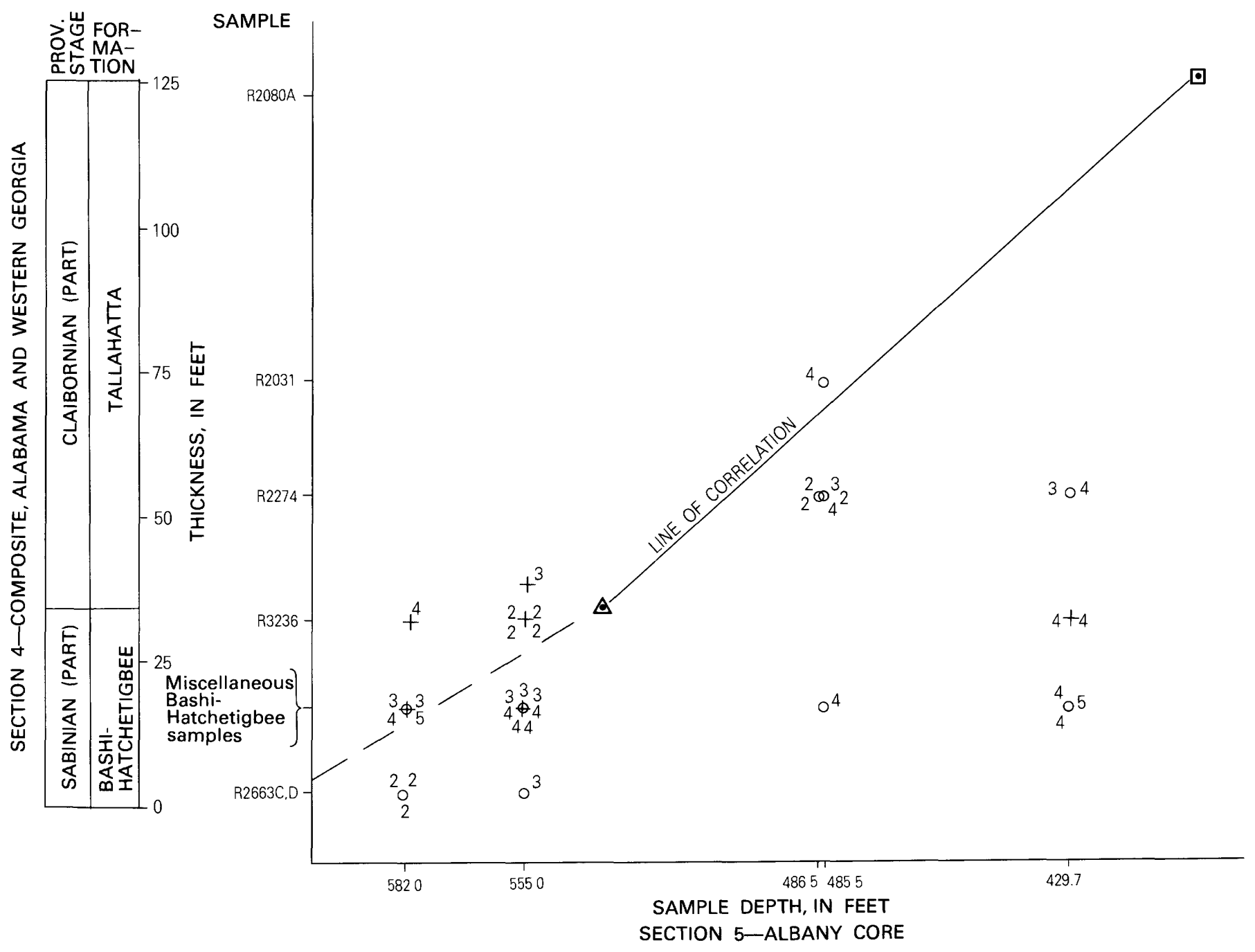

FIGURE 8.-Graphic correlation of sections 4 and 5 showing only higher quality events. The dot enclosed by a triangle is the contact between the Bashi-Hatchetigbee interval and the Tallahatta Formation; the dot enclosed by a square is the contact between the
Tallahatta and Lisbon Formations. The lower part of the line of correlation is dashed because the base of the Bashi Formation is uncertain in the Albany core. Data points are events $(0=$ range base; $+=$ range top) accompanied by tentative event rankings. hatta) are somewhat low-quality events, and in the study of figures 9 and 10 (graphic correlation charts of sections $3 B$ and $4+5$ ) I found that the many range tops in the core sample from $429.7 \mathrm{ft}$ are tops of unfilled ranges (in the terminology of Edwards, 1978). Thus, figure 8 cannot be used to subdivide the Tallahatta Formation biostratigraphically.

As previously noted, figure 8 supports the placement, on lithologic grounds, of the Bashi-Tallahatta contact at $538 \mathrm{ft}$ depth in the Albany core, and a comparison of sections $3 \mathrm{~B}$ and $4+5$ (fig. 10) supports the lithologic placement of the Tallahatta-Lisbon contact at $401 \mathrm{ft}$ in the core (table 3; dot enclosed by a square in fig. 8).
Therefore, I have considered these contacts to be the endpoints of the line of correlation in figure 8 and have used this line in compositing OTU ranges for figure 9 (comparison of sections $3 \mathrm{~B}$ and $4+5$ ) and for compiling the composite standard section (pl. 17, in pocket).

As mentioned previously, the position of the base of the Bashi Formation (that is, the position of the Paleocene-Eocene boundary) in the Albany core is uncertain but is known to be below $611.5 \mathrm{ft}$. If the top of the Bashi Formation is at $538 \mathrm{ft}$ in the core, which is reasonable on the basis of lithology (table 3 ) and biostratigraphy (fig. 8), and if the ratio of the thickness of Bashi to Tallahatta is the same in the Albany core as 
in nearby westernmost Georgia (see description of section 4), then the base of the Bashi would be at $589 \mathrm{ft}$ in the Albany core. For purposes of fitting Bashi Formation samples from the Albany core into the composite standard section ( $\mathrm{pl} .17$, in pocket), I have assumed that the base and top of the Bashi in the core are at depths of $615 \mathrm{ft}$ and $538 \mathrm{ft}$, respectively.

\section{GRAPHIC CORRELATION OF SECTIONS 3B AND $4+5$}

Eighty-two OTU's are common to section 3B, Little Stave Creek (fig. 4), and composite section $4+5$ (figs. 5, 6). However, 46 of these OTU's are known to range down into strata older than the Tallahatta Formation, which forms the base of section 3B; thus, apparent range bases of these OTU's in sections $3 B$ and $4+5$ are of no significance in correlations between these two sections. Thirty-nine OTU's common to sections $3 \mathrm{~B}$ and $4+5$ are known to range up into strata overlying the Lisbon Formation and its equivalents in the Gulf and Atlantic Coastal Plains. Apparent range tops of these OTU's in sections $3 B$ and $4+5$ are of no significance in correlations between the two sections because the top of section $4+5$ is the top of the Lisbon Formation. In addition, I disregarded the occurrence of two specimens of Thomsonipollis magnifica (OTU 137) in sample R2082I (Lisbon Formation) at Little Stave Creek (fig. 4); this species probably does not range above the Bashi and Hatchetigbee Formations and their correlatives in the Gulf Coast (Elsik, 1974a), although it is often found reworked into younger strata (for example, Frederiksen, 1980c). Tschudy (1973) reported this species in the Reklaw Formation (Tallahatta equivalent) of Texas, but Elsik (1968b) considered that this species occurred in the Reklaw only as reworked specimens. In the present study, I have not found Thomsonipollis magnifica in any Tallahatta sample, suggesting that Elsik (1968b) was correct and that the specimens in the Lisbon at Little Stave Creek are reworked.

As a result of these reductions in the number of usable events, 78 potentially significant events (40 range bases and 38 range tops) remain for graphic correlation of sections $3 B$ and $4+5$, and these are plotted in figure 9. However, it is clear from the broad scatter of event points in figure 9 that no reliable line of correlation can be drawn on the basis of these points (the line of correlation in figure 9 was drawn later, on the basis of better data).

The scatter of data points in figure 9 means that most or all observed events occur at different stratigraphic levels in the two sections. These observations may reflect real differences in local range bases and tops. However, considering the fact that Little Stave Creek and the Albany core are only $225 \mathrm{mi}$ apart (fig. 2), it is much more likely that many OTU ranges in each sec- tion are really longer than was observed; that is, many observed bases and tops are unfilled-range events.

Figure 10 is a plot of the higher quality events of figure 9; the numbers next to the data points in figure 10 are summed rankings. The pattern of event points in figure 10 is much more usable than the pattern in figure 9 , as even a cursory inspection of the data points in figure 10 shows a pattern extending from lower left to upper right, particularly if one ignores all points except those having a tentative ranking of 2 . Boxes are drawn in figure 10 (for points having a ranking of 2) following the practice of Edwards (1984). For a range base, it is assumed that the OTU really does not occur in the samples below the lowest one in which it was observed. However, because a gap exists between the sample containing the lowest observed occurrence and the next lower sample in the section, the true range base of the OTU could be anywhere in the interval between the lowest sample in which it was observed and the next lower sample. The box outlines a confidence region within which it is assumed that the true range base lies for the OTU in the two sections. Following the same reasoning, a box forming a confidence region is drawn for each range top. Each data point is not in the center of its confidence region, but rather at one corner of it. The original event points have now become event confidence regions, and the geologically most reasonable line of correlation will pass through as many boxes (at least high-quality boxes) as possible but not necessarily through many, if any, of the original event points.

The position of the base of the line of correlation in figure 10 is somewhat uncertain because few data points are available for this part of the diagram. The dashed lower segment of the line of correlation is based on an assumed total thickness of $180 \mathrm{ft}$ for the Tallahatta Formation in the Little Stave Creek area, the position of the contact between the Bashi-Hatchetigbee interval and the Tallahatta Formation in section 4, and the tentatively picked lithologic contact in section 5 (table 3).

The position of the line of correlation in the vicinity of the Tallahatta-Lisbon contact should fall within the area enclosed by the range bases of Ephedra claricristata (event 27 in figure 9), Carya $>28 \mu \mathrm{m}$ (109), and Nuxpollenites crockettensis (237) and the range tops of Milfordia hungarica (event 40) and Carya $<29 \mu \mathrm{m}$ (108). The Tallahatta-Lisbon contact at Little Stave Creek and the tentatively picked lithologic contact in the Albany core are shown in figures 9 and 10 by a dot enclosed by a square. This point falls well within the area within which I would draw the line of correlation based on high-quality event points; my biostratigraphic data thus support the lithologic pick of the Tallahatta-Lisbon boundary at approximately $401 \mathrm{ft}$ 
depth in the Albany core, and I have used the lithostratigraphic event represented by the boundary at Little Stave Creek and the probable boundary in the Albany core as a data point on the line of correlation in figure 10.

In the middle part of the Lisbon Formation, the only two events having an initial ranking of 2 are the range top of Lanagiopollis hadrodictya (event 300 in figure 9) and the range base of Lymingtonia cf. L. rhetor (169). These two event points are far apart, but it is probable that the line of correlation passes between them.

The top of the Lisbon Formation and the base of the Jacksonian Stage in the Albany core was tentatively placed at $239 \mathrm{ft}$ depth on lithologic grounds (table 3); this level in the core is a boundary between limestone and subordinate sandstone beds above and more abundant and thicker sandstone strata interbedded with limestone strata below. The Gosport Formation, which is between the Lisbon and the Jacksonian updip and to the west and forms the top of the Claibornian Stage there, was not recognized lithologically in the Albany core. According to the tentative contact placement (table 3), the core sample from $256.0 \mathrm{ft}$ should belong to the Lisbon Formation. Most pollen OTU's in this sample (fig. 6) are known to range from the Lisbon into the Jacksonian, but several are probably restricted to the Lisbon and lower formations. Nuxpollenites claibornensis (OTU 235) and $N$. crockettensis (237) are not known from above the Cook Mountain Formation in Texas (Elsik, 1974a), the equivalent of the upper part of the Lisbon Formation in Alabama. These two species have not been found as high as the uppermost part of the Claibornian in South Carolina (Frederiksen, 1980b). In fact, no specimens of the genus Nuxpollenites have been found in the Jacksonian Stage of the Gulf Coast or South Carolina (Elsik, 1974a; Frederiksen, 1980b, c). Celtipollenites gracilis (157) has been found only as high as sample UCR 8092 at Little Stave Creek, $66 \mathrm{ft}$ below the top of the Lisbon there. Porocolpopollenites ollivierae (tricolporate and tetracolporate types, OTU's 291 and 343, respectively) were found ranging to the top of the Lisbon Formation at Little Stave Creek (fig. 4); they were not recorded in the Gosport Formation or Jacksonian Stage in Mississippi or Alabama (Frederiksen, 1980c) but might possibly have been overlooked in those stratigraphic units. However, in South Carolina, $P$. ollivierae was not found to range as high as the uppermost Claibornian (Frederiksen, $1980 \mathrm{~b})$. In short, the presence of Nuxpollenites claibornensis, $N$. crockettensis, Celtipollenites gracilis, and perhaps Porocolpopollenites ollivierae in the Albany core sample from $256.0 \mathrm{ft}$ suggests that this sample is in the Lisbon. Therefore, my pollen range data support the tentative lithologic placement of the top of the Lis- bon at $239 \mathrm{ft}$ in the core and suggest that the line of correlation lies close to the core sample from $256.0 \mathrm{ft}$.

Disregarding events at the intersection of the uppermost samples, R2082T (section 3B) and $256.0 \mathrm{ft}$ depth (section 5), the main high-quality event points in the upper right part of figure 10 are range tops of Celtis tschudyi group (triporate) (event 124 in fig. 9), Momipites-Plicatopollis-Platycaryapollenites complex (98), and Plicatopollis triradiata (96) and the range base of Juglanspollenites infrabaculatus (167). If the line of correlation is drawn directly from the Tallahatta-Lisbon formation contact (dot enclosed by a square) to the contact between the Claibornian and Jacksonian Stages (dot enclosed by a diamond), the line passes through the range top confidence region of $\mathrm{Pli}$ catopollis triradiata (event 96 ), but the confidence regions of events 124,98 , and 167, are all to the left of the line. However, one important feature of figure 9 is that, in the Lisbon Formation, nearly four times as many range tops are to the left of the line of correlation as to the right of it. This means that, if the position of the line is even approximately correct, many OTU's appear to range significantly higher stratigraphically at Little Stave Creek than in the Albany core. Most of these OTU's were not observed to range higher than the Tallahatta Formation or the lowermost part of the Lisbon Formation in the Albany core but range well up into the Lisbon at Little Stave Creek. There are probably two main reasons why many OTU's appear to range higher at Little Stave Creek. First, the Little Stave Creek samples are richer in sporomorphs; the average Lisbon sample there contains 22.6 OTU's, whereas the average Albany core sample in the Lisbon contains only 17.3 (figs. 4, 6). Second, 13 samples were examined from the Lisbon at Little Stave Creek, whereas only 6 were examined from the formation in the Albany core, and only 2 samples were available from the upper half of the Lisbon in the core as opposed to 8 at Little Stave Creek. In short, the occurrence data available from the Albany core are such that most observed OTU ranges in the core are likely to be unfilled. Therefore, it is reasonable to find most range top confidence regions to the left of the line of correlation in the upper part of the Lisbon in figure 10, and I conclude that the line is in a reasonable position as drawn.

\section{GRAPHIC CORRELATION OF SECTIONS 2B AND 3B $+4+5$}

Section 2B (eastern Mississippi) consists of three samples from the Tallahatta Formation, one sample from the lower part of the Winona Formation, and one sample from the upper part of the Kosciusko Formation (fig. 3). The Winona Formation is thought to be correlative with the lowest part of the Lisbon Formation of 


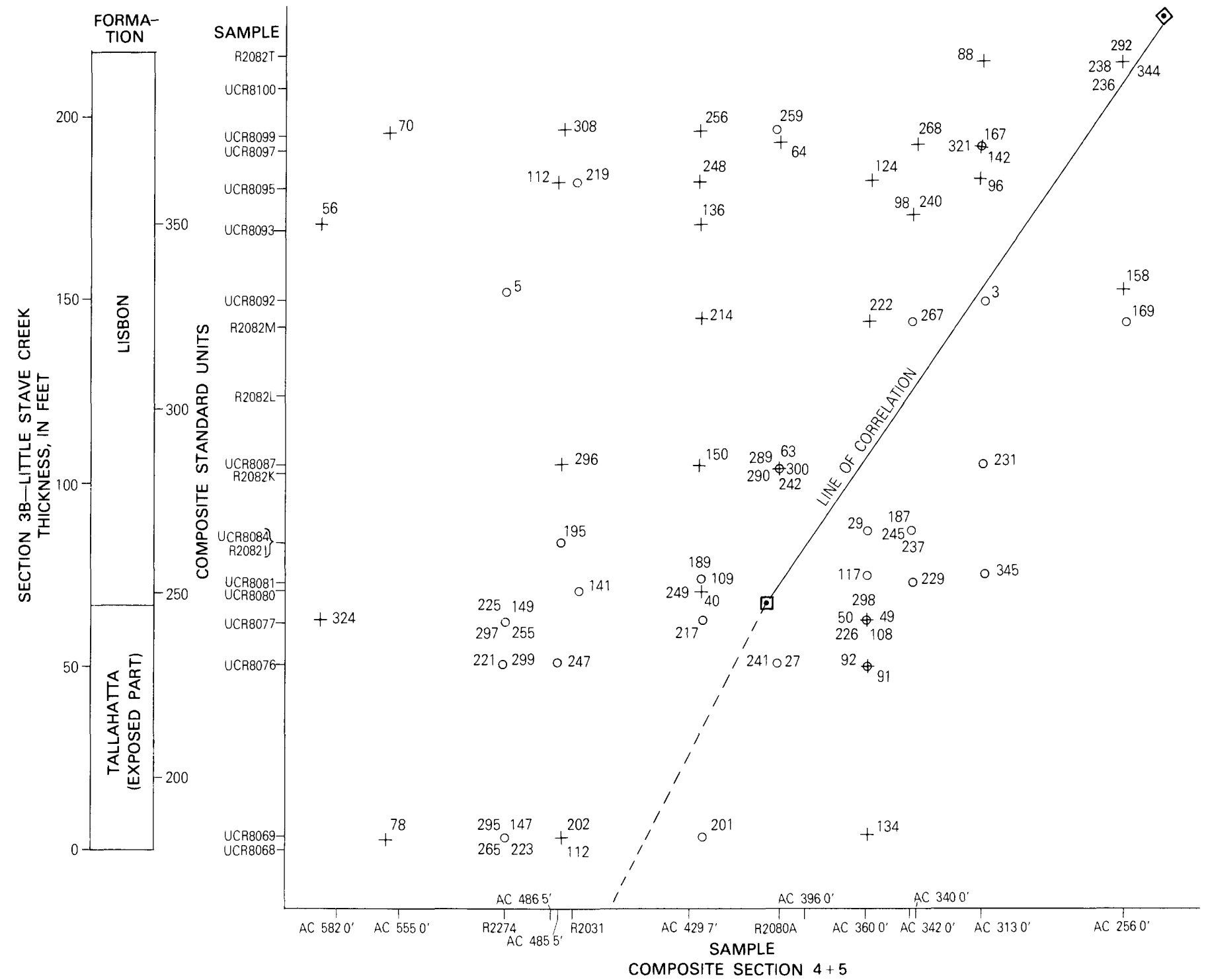

FIGURE 9.-Graphic correlation of sections $3 B$ and $4+5$ showing all events. The dot enclosed by a square is the contact between the Tallahatta and Lisbon Formations, and the dot enclosed by a diamond is the top of the Claibornian Stage. The lower part of the line of correlation is dashed because of the scarcity of good data from this part of the section (see text). Data points are events ( $O=$ range base; $+=$ range top) accompanied by event numbers.
Alabama, and the Kosciusko Formation is thought to be correlative with the middle part of the Lisbon, but the Winona-Zilpha-Kosciusko Formation sequence in Mississippi contains few if any calcareous nannofossils (Siesser, 1983); thus, the exact correlation of these units with parts of the Lisbon is uncertain. Therefore, aside from input of OTU range bases and tops into the composite standard section (pl. 17, in pocket), the main interest of section $2 \mathrm{~B}$ is in comparing the TallahattaWinona boundary in eastern Mississippi (section 2B) with the Tallahatta-Lisbon boundary in western Alabama (section 3B) and western Georgia (section 5) and in determining the correlation of sample R2353, Dobys Bluff Tongue (of Dockery, 1980) of the Kosciusko Formation (of Thomas, 1942) of eastern Mississippi, with some part of the Lisbon Formation of western Alabama.

Eighty-eight OTU's are common to section $2 \mathrm{~B}$ and composite section $3 \mathrm{~B}+4+5$. Even after discarding many potential events from consideration because, in 


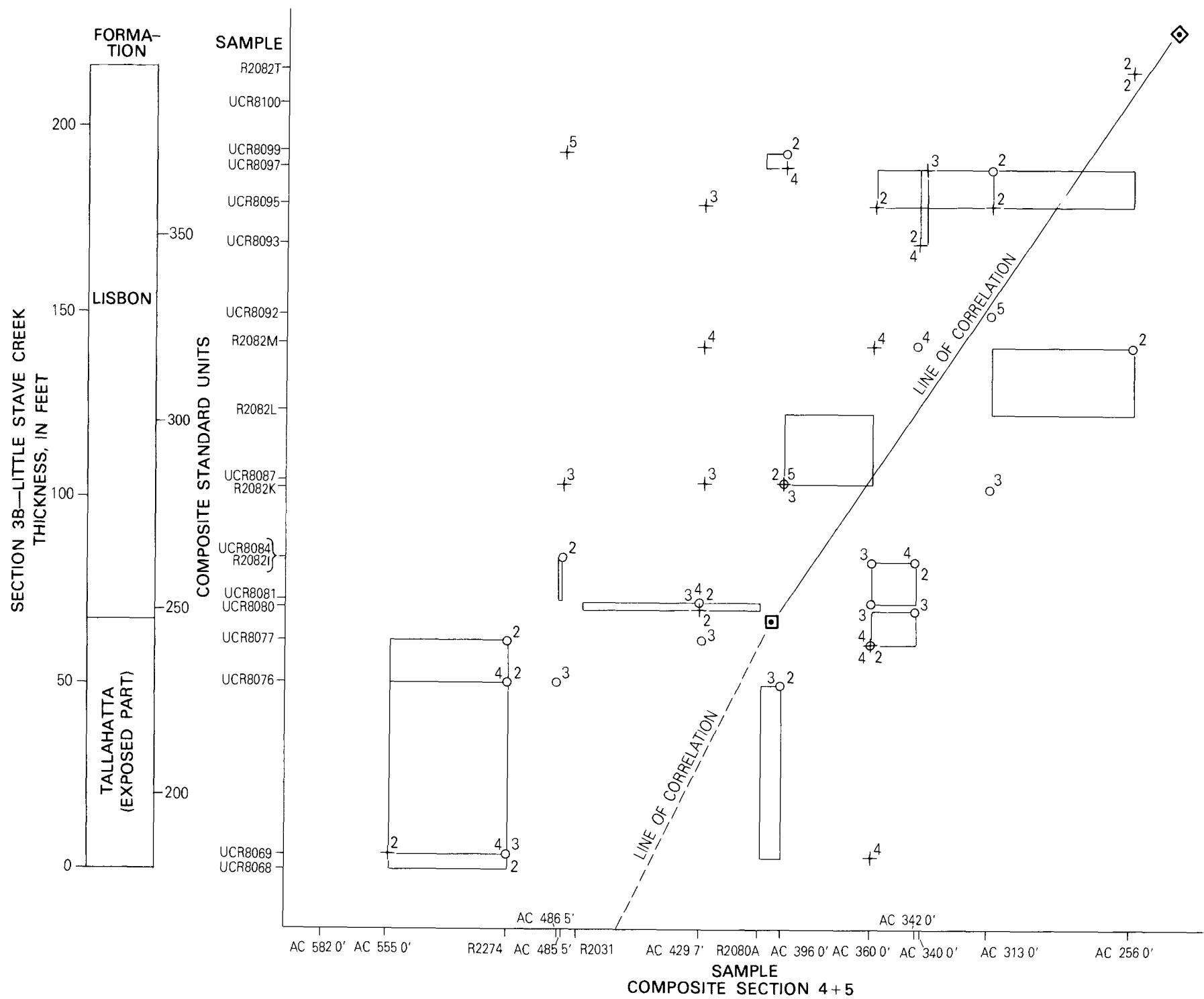

FIGURE 10.-Graphic correlation of sections $3 B$ and $4+5$ showing only higher quality events. The dot enclosed by a square is the contact between the Tallahatta and Lisbon Formations, and the dot enclosed by a diamond is the top of the Claibornian Stage. The lower part of the line of correlation is dashed because of a scarcity

of good data from this part of the section (see text). Data points are events ( $O=$ range base; $+=$ range top) accompanied by tentative event rankings. Boxes are confidence regions for the highest ranked event points.

at least one section, they are range bases lower than the Tallahatta or range tops higher than the Lisbon, a graphic correlation plot of the remaining events in sections $2 \mathrm{~B}$ and $3 \mathrm{~B}+4+5$ produced a nearly useless chart (fig. 11). The problem with this chart is that most OTU's appear to range much higher in the composite section than in section $2 \mathrm{~B}$ simply because only one sample is available from above the Tallahatta-Winona boundary zone in section 2B. Also, it is apparent from the clusters of range bases below the line of correlation in samples R1507A and R1507B that these OTU's actu-

ally have their range bases lower in the section than these Tallahatta samples in eastern Mississippi.

Assigning tentative quality rankings to events in figure 11 was difficult because section $2 \mathrm{~B}$ contains few, generally widely spaced samples; furthermore, some OTU's were not observed in all the sections (3B, 4 , and 5) making up the vertical axis in figure 11 . For events in section $2 \mathrm{~B}$, I assigned a ranking of 1 to OTU's that were found in at least two samples. A few OTU's that were found in section $2 \mathrm{~B}$ only in sample R2353 and were known to have their range base in about the mid- 


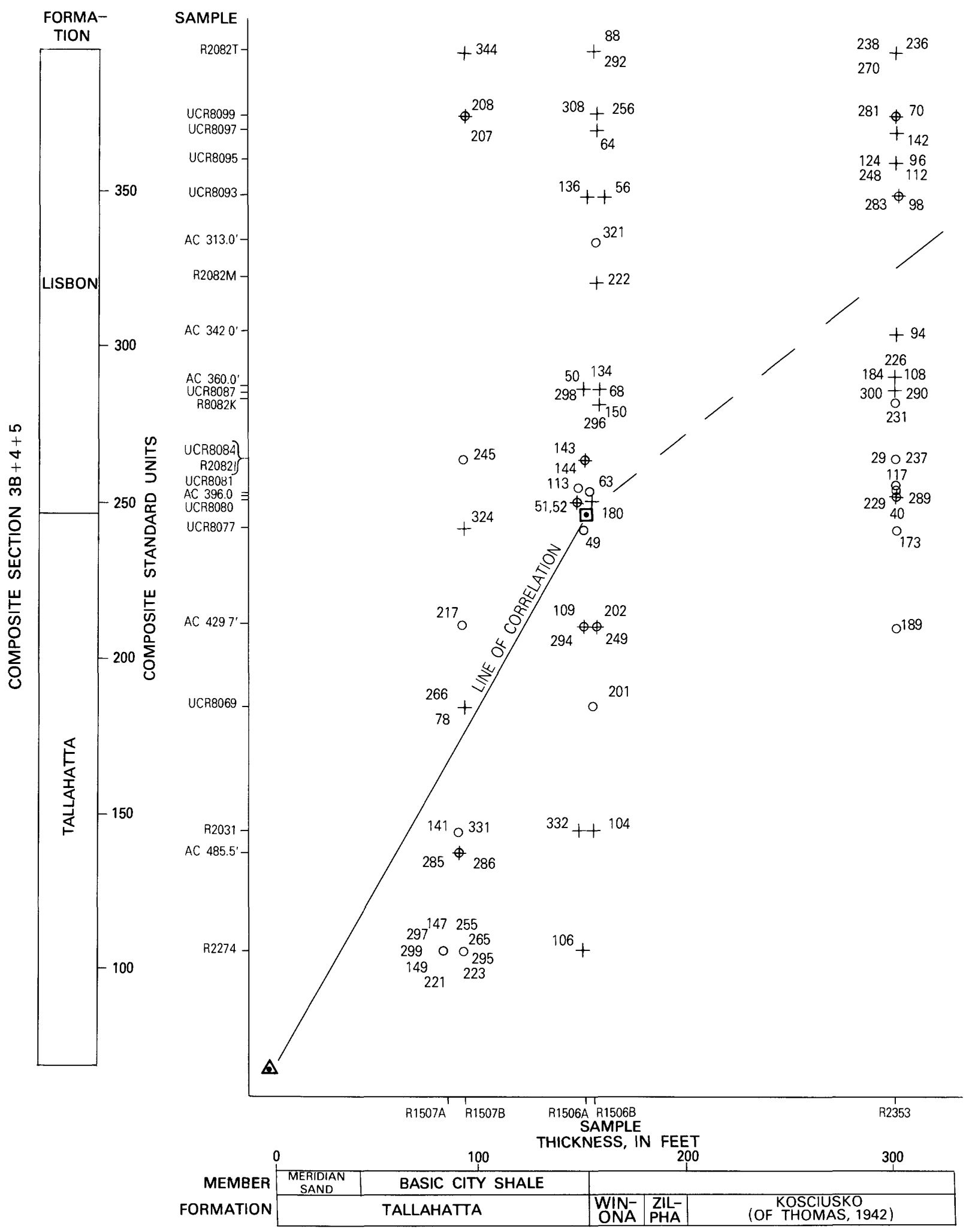

SECTION 2B-EASTERN MISSISSIPPI

FIGURE 11.-Graphic correlation of sections $2 B$ and $3 B+4+5$ showing all events. The dot enclosed by a triangle is the base of the Tallahatta Formation, and the dot enclosed by a square is the top of the Tallahatta. The dashed line of correlation connects the top of the Tallahatta with the top of the Lisbon Formation (just above sample R2082T) and with the correlative horizon of the horizontal axis, the top of the Cook Mountain Formation (not shown; about $440 \mathrm{ft}$ above the base of the Tallahatta Formation in eastern Mississippi). Data points are events $(O=$ range base; $+=$ range top) accompanied by event numbers. 
dle third of the Lisbon Formation or higher also were assigned a ranking of 1 . Other OTU's in section 2B received a ranking of 2 . I ranked the events in sections $3 \mathrm{~B}, 4$, and 5 by examining the occurrences of the OTU's in the Little Stave Creek section (section 3B) and ranking them using the same criteria as for figures 8 and 10 . However, I then reduced this ranking number (that is, upgraded the rank) by 0.5 if the OTU was also found in section 4 and by another 0.5 if the OTU was also found in section 5 (but only if it was found above the BashiHatchetigbee interval in each case). Therefore, the numbers are generally lower (that is, the rankings suggest slightly higher quality events) in figure 12 than in figures 8 and 10 .

In figure 12 , confidence regions are shown for events ranked 1 or 1.5 . Figure 12 is an improvement over figure 11 , and the confidence regions and data points in figure 12 suggest that the position of the dashed line of correlation is not unreasonable, but of course the resolution even of figure 12 is not very good because section 2B includes so few samples.

Previously published correlation charts (for example, Fisher, 1964; Hazel and others, 1977; Toulmin, 1977; and Dockery, 1980) considered the top of the Kosciusko Formation of Mississippi to be equivalent to the middle of the Lisbon or even correlative with the uppermost part of the middle third of the Lisbon Formation of Alabama. Figure 13 shows the ranges, at Little Stave Creek and the Albany core, of the most important OTU's in sample R2353, which is near the top of the Kosciusko. OTU's 69 and 39 (Triatriopollenites sparsus group and Milfordia hungarica) are probably reworked in the sample. OTU 289 (Symplocos? sp. 1) may or may not be reworked; the range of this OTU is not well known because relatively few specimens have been found. Similarly, the range base of OTU 283 (Symplocos? jacksoniana) is not well known because this species is rare in the Claibornian Stage. Tschudy (1973) recorded OTU 183 (Dicolpopollis spp.) only from the Hatchetigbee Formation and from the Reklaw Formation (Tallahatta equivalent), and in this study I also found the genus in the uppermost part of the Tallahatta Formation and the lowermost part of the Winona Formation in eastern Mississippi (fig. 3); thus, the presence of the genus in the Albany core sample from 360.0 $\mathrm{ft}$, where it is unlikely to be reworked, is the highest known occurrence of the genus in the Gulf Coast, and I suspect that the genus does not range much higher than this level. Unless OTU's 299, 107, 183, and 225 are all reworked, sample R2353 should not be younger than the Albany core sample from $360.0 \mathrm{ft}$ or Little Stave Creek sample UCR 8087, which is about the same age as AC $360.0^{\prime}$ according to the line of correlation in figure 10. If the range bases of OTU's 231 and
235 are correct, sample R2353 should also not be older than sample R2082K of Little Stave Creek. Therefore, if the Lisbon Formation at Little Stave Creek were divided into three equal parts, the uppermost part of the Kosciusko Formation of eastern Mississippi should correlate approximately with the boundary between the lower and middle thirds of the Lisbon rather than with the middle of the formation or even with the upper part of the middle third of the Lisbon, as suggested by authors cited previously. In terms of mollusk zones, the upper part of the Kosciusko Formation appears to correlate (on the basis of sporomorphs) with the lower part of the Cubitostrea sellaeformis Zone rather than with the middle part of this zone at Little Stave Creek (Bandy, 1949).

The dashed leg of the line of correlation in figure 12 connects the top of the Tallahatta with (1) the top of the Lisbon at Little Stave Creek (the thickness shown for the Lisbon in the vertical axis of fig. 12 is the formation thickness at Little Stave Creek) and (2) with the top of the Cook Mountain Formation of Mississippi; that is, this is the line of correlation that would exist if the ratio of rate of deposition at Little Stave Creek and in eastern Mississippi remained constant throughout Lisbon time and if the top of the Lisbon were the same age as the top of the Cook Mountain. The dotted leg of the line of correlation in figure 12, connecting the top of the Tallahatta with point $S$, is based on the sporomorph correlation of sample R2353 of eastern Mississippi with the interval between samples R2082K and AC $360.0^{\prime}$ in Alabama and Georgia. A geologic consequence of this sporomorph correlation is that the dotted line should steepen above point $S$ so that the continuation of the dotted line would intersect the dashed line at the top of the Lisbon and the top of the Cook Mountain. This means that the average ratio of rate of deposition in eastern Mississippi relative to the rate at Little Stave Creek decreased considerably after Kosciusko time over what it had been during Winona to Kosciusko time.

\section{CORRELATION WITHIN THE JAGKSONIAN STAGE AND ADJACENT STRATA}

In 1980 (Frederiksen, 1980c), I listed the occurrences of 174 sporomorph taxa in the uppermost Claibornian, the Jacksonian, and the lowermost Vicksburgian Stages in three sections-western Mississippi, eastern Mississippi, and western Alabama. Most of these taxa were found to range throughout this sequence and thus were useless for biostratigraphically subdividing the interval. Only 11 of the taxa were thought to have useful range bases or tops and also to be present in a reasonable number of samples. The ranges of these 11 


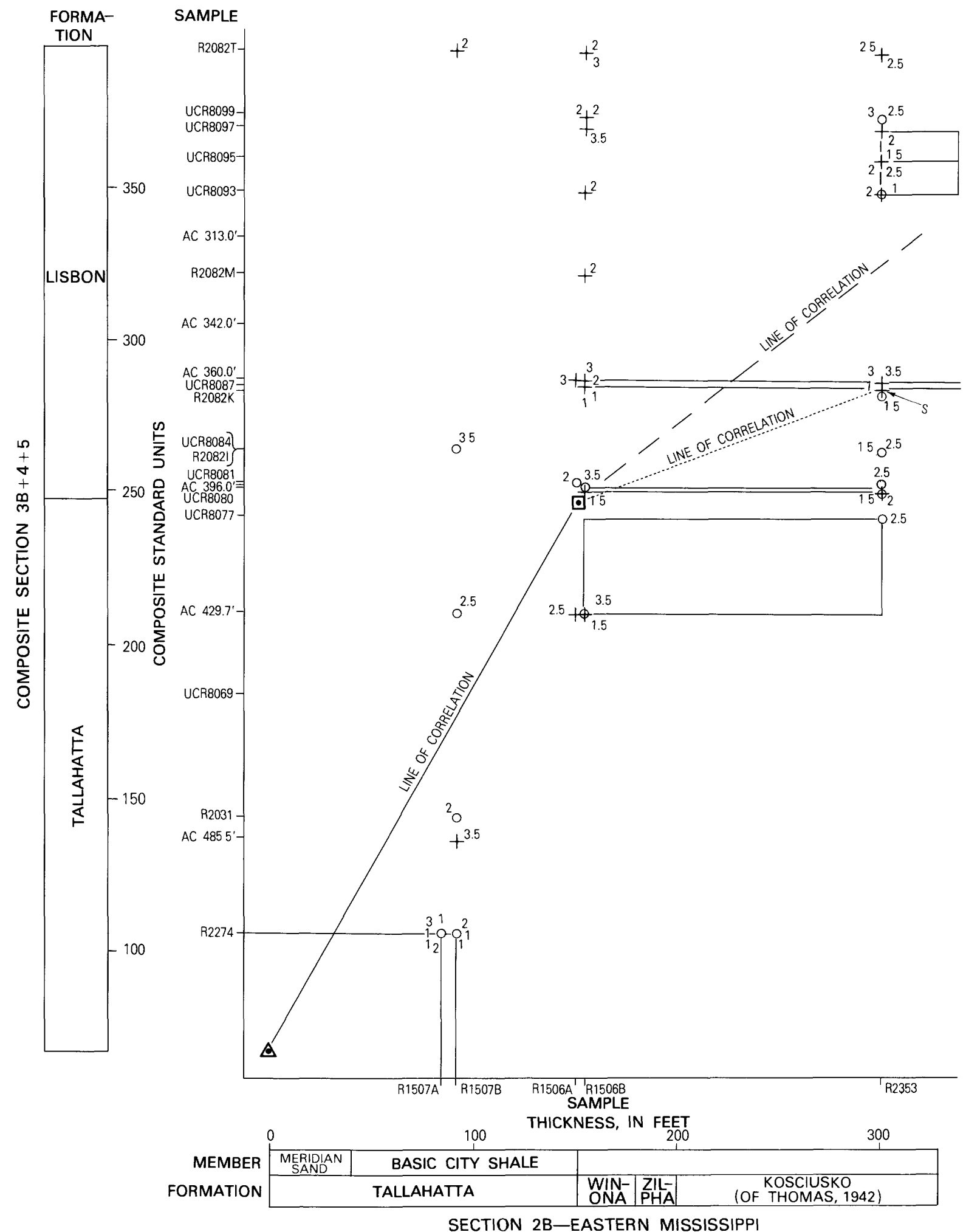




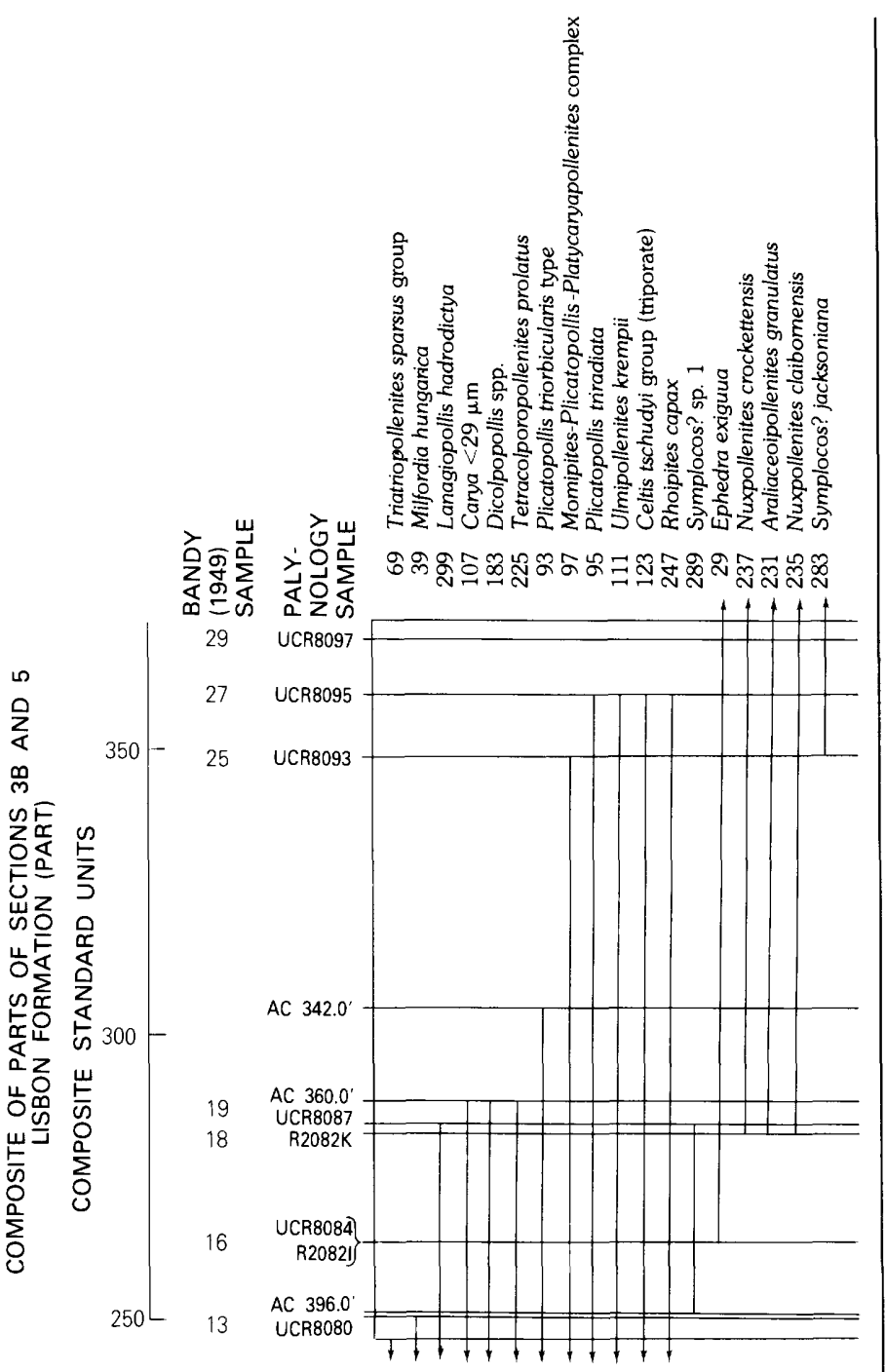

FIGURE 13.-Stratigraphic ranges of age-diagnostic operational taxonomic units found in sample R2353 of the Dobys Bluff Tongue (of Dockery, 1980), Kosciusko Formation (of Thomas, 1942), Clarke County, Miss. These are the ranges in a composite section formed of sections 3B (Little Stave Creek; $R$ and UCR sample numbers) and 5 (Albany core; AC sample numbers). Sample UCR 8080 is from the lowermost part of the Lisbon Formation; sample UCR 8097 is from the upper but not uppermost part of the Lisbon (see sample positions in fig. 11). taxa were plotted on a single composite section for the region from western Mississippi to western Alabama (Frederiksen, 1980c, fig. 4), and, partly on the basis of range bases and tops, two zones were defined within the sequence. Zone I was considered to extend from the upper part of the Claibornian nearly to the top of the Jacksonian, and Zone II extended from the uppermost part of the Jacksonian into the lower part of the Vicksburgian. In the present paper, I have tried graphic correlation rather than inspection to define biostratigraphic events within this sequence. I also used occurrence data for 17 taxa, some of which were found in only 5-8 samples, rather than for 11 taxa as previously. Graphic correlation has also allowed a more accurate determination of the total range of each of these taxa in the sequence.

Compositing ranges within the Jacksonian and adjacent strata to produce the composite standard section (pl. 17, in pocket) requires correlations to be made among the three studied sections containing this sequence-sections $1,2 \mathrm{~A}$, and $3 \mathrm{~A}$ (fig. 1), which were described in detail by Frederiksen $(1969,1980 \mathrm{c})$. Correlations between eastern Mississippi and western Alabama are good because the Yazoo Clay, which makes up most of the Jacksonian in the eastern Gulf Coast, can be divided in these two areas into four members that can be correlated lithologically as well as on the basis of several kinds of fossils (see the section of this paper on the "Composite Standard Section"). However, correlations within the Yazoo Clay from eastern Mississippi to western Mississippi are not easy. A detailed discussion of correlation problems within the Yazoo Clay is deferred to the section of the paper on the "Eocene-Oligocene Boundary." At this point I will only mention two possible correlations, which suggest, respectively, that (1) the rate of deposition remained constant in western Mississippi relative to the rate in eastern Mississippi-western Alabama, or that (2) the rate of deposition increased greatly during Yazoo time in western Mississippi relative to the rate in eastern Mississippi-western Alabama, so that much or most of the Yazoo Clay of western Mississippi is correlative
FIGURE 12.-Graphic correlation of sections $2 \mathrm{~B}$ and $3 \mathrm{~B}+4+5$ showing only higher quality events. The dot enclosed by a triangle is the base of the Tallahatta Formation, and the dot enclosed by a square is the top of the Tallahatta; the symbol, $S$ indicates the sporomorph correlation of sample R2353 of eastern Mississippi with the interval between samples R2082K and AC $360.0^{\prime}$ on the vertical axis. The dashed line of correlation assumes a constant ratio of rate of deposition at Little Stave Creek and in eastern Mississippi (see text) and connects the top of the Tallahatta Formation with the top of the Lisbon Formation (just above sample R2082T) and with the correlative horizon of the horizontal axis, the top of the Cook Mountain Formation (not shown; about $440 \mathrm{ft}$ above the base of the Tallahatta Formation in eastern Mississippi). The dotted line connects the top of the Tallahatta Formation with point S. Data points are events $(\mathrm{O}=$ range base; $+=$ range top) accompanied by tentative event rankings. Boxes are confidence regions for the highest ranked event points. 
with the Shubuta Member, the uppermost member of the Yazoo, to the east.

Figure 14 is a graphic correlation plot of combined sections 2A (eastern Mississippi) and 3A (western Alabama) vs. section 1 (western Mississippi). Eighteen events based on range tops and (or) bases of 17 OTU's are shown. The range tops of Chrysophyllum? brevisulcatum (OTU 215) and the Triatriopollenites convexus group (59) and the range base of Ericipites aff. E. ericius (Potonié 1931) Potonié 1960 were not included in figure 14 as they were in Frederiksen (1980c, fig. 4). Chrysophyllum? brevisulcatum has since been found to range up at least into the lower Vicksburgian (Frederiksen, 1981, table 16-2); all specimens of the Triatriopollenites convexus group in the Jacksonian are now thought probably to be reworked; and I am not sure of the position of the range base of Ericipites aff. E. ericius because I did not tabulate tetrads in my work on the Claibornian for this paper. On the other hand, figure 14 does include range data on nine OTU's additional to those used for figure 4 of Frederiksen (1980c)-Undulatisporites concavus (OTU 15), Lycopodium venustum (17), Sphagnum triangularum (23), Cedrus piniformis (25), Milfordia incerta (41), Milfordia minima (43), Rhoipites subprolatus (251), Gothanipollis cockfieldensis (271), and Reticulataepollis reticlavata (333).

As stated previously, one of the main objects of figure 14 is to determine which is more likely to be correct, a rapid increase in rate of deposition in western Mississippi relative to the other two sections during Shubuta time (dashed line of correlation in fig. 14) or a relatively constant ratio of rate of deposition between the sections forming the axes of the diagram during the whole of Yazoo time (dotted line of correlation). Unfortunately, the diagram does not answer the question (1) because of a lack of events in the lower half of the Yazoo Clay of western Mississippi and (2) because most range tops are significantly higher in section 1 than in sections $2 \mathrm{~A}$ and $3 \mathrm{~A}$. The reason for the higher range tops in section 1 is that the Yazoo and Red BluffBumpnose Formations to the east are significantly more calcareous and less rich in pollen than the Yazoo and Forest Hill Formations to the west.

The diagram is somewhat misleading as regards the amount of bend in the dashed line of correlation. The reason is that I used the western Alabama section (section $3 \mathrm{~A}$ ) as the basis of formation thicknesses in figure 14 ; in this section the Shubuta Member of the Yazoo is only $17 \mathrm{ft}$ thick, whereas the member thickens to $84 \mathrm{ft}$ in eastern Mississippi. As discussed later in the paper, there is a serious discrepancy between lithologic and paleontologic data as to the location of the line of correlation for the Yazoo Clay in figure 14. However, I assume that the dashed line in figure 14 is more nearly correct than the dotted line, and in compositing the ranges of OTU's within the Yazoo Clay for plate 17 (in pocket), I used the dashed line of correlation.

\section{COMMENTS ON THE PRACTICE OF GRAPHIC CORRELATION}

Graphic correlation has traditionally been applied to biostratigraphic problems in which a heavily sampled composite standard section was compiled and then used to correlate other heavily sampled sections in the region. However, in practice, paleontologists often do not have time to examine large numbers of samples and (or) to tabulate large numbers of taxa for a particular project, and the question arises as to how effective graphic correlation can be under these conditions. In this study, I examined 48 samples from the base of the Eocene to the top of the Lisbon Formation. The samples were from four sections, including 17 samples from 16 stratigraphic levels in the standard reference section (Little Stave Creek). One hundred forty-eight OTU's were tabulated for this part of the paper (figs. 3-6). Thus, in this part of the present study, the number of samples was relatively small but the number of taxa was relatively large.

Several paleontologists who have used graphic correlation (Shaw, 1964; Miller, 1977; Edwards, 1979, 1984; Sweet, 1979) have pointed out that the line of correlation cannot simply be drawn as a best fit through the original cloud of data points on the correlation diagram; the individual range bases and tops must be evaluated to find the best fit of the line of correlation to the points. However, these authors seem to have limited their judgment largely to acceptance or rejection of individual event points. The present study strongly supports the idea that a preliminary evaluation of the probable value of each event for graphic correlation is very important in limiting the data points to those that are most likely to reflect true range bases and tops (compare figs. 7 and 9 with figs. 8 and 10). It would be complicated and probably impossible to determine precise rankings for the events in each section, but even rather crude tentative rankings, as in this study, are of considerable help. The highest rankings should be assigned to events that represent range bases or tops of taxa observed in most or all samples within their local ranges. However, in order to make the tentative rankings, it is necessary to have the raw occurrence data at hand, as in figures 3-6 of this paper; thus, a computer printout showing only range bases and tops is of little or no value for ranking the events. A high ranking could also be assigned events that are found in only one or two samples, if these are (1) range tops at or near the base of the study section, (2) range bases at or near the top of the study section, or (3) 

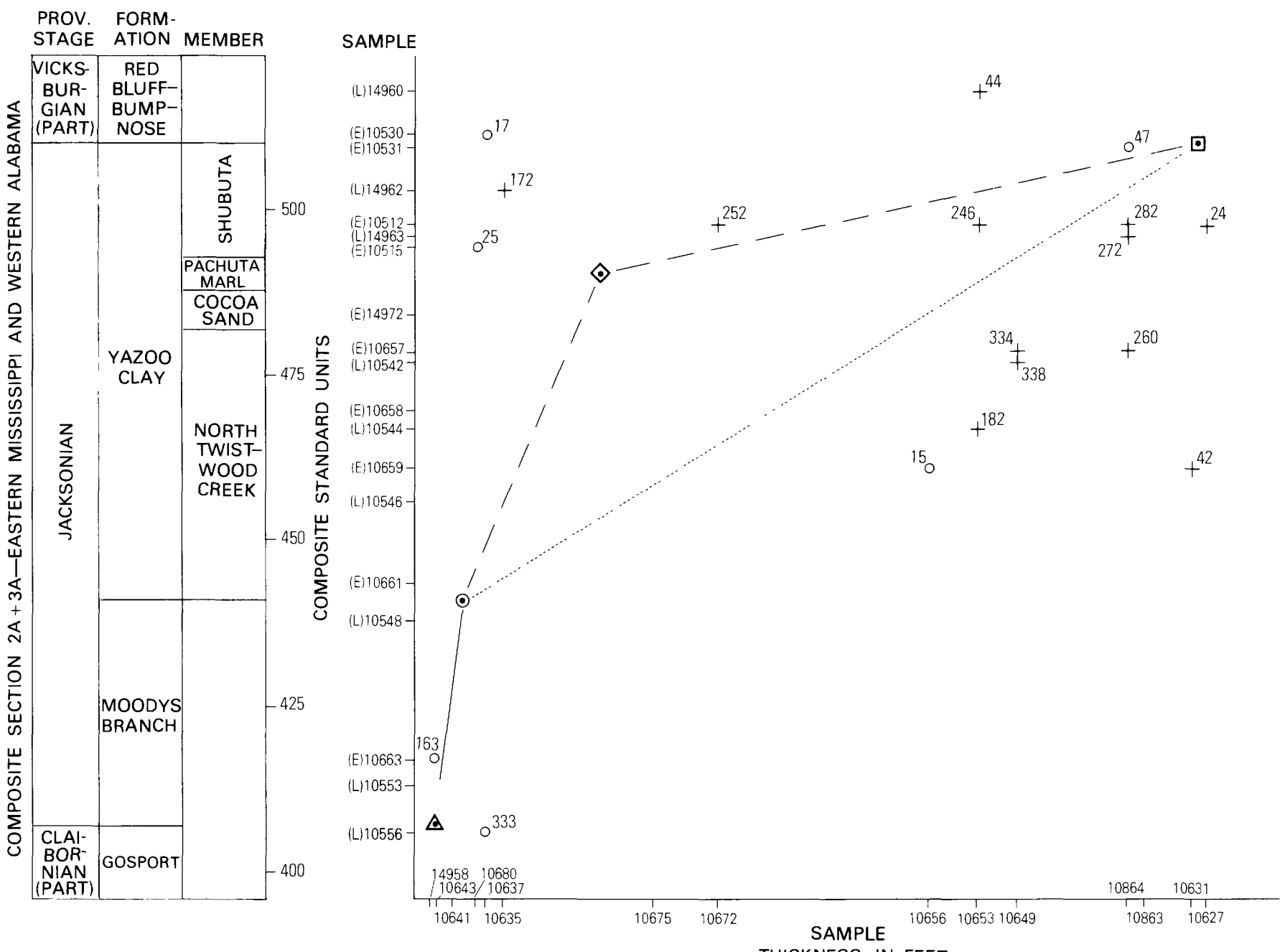

1 COCKFIELD (PART)

3 CLAIBORNIAN (PART)

\begin{tabular}{|c|c|c|c|c|c|}
\hline & 0 & $\stackrel{100}{1}$ & $200^{\text {THICKNESS, IN FEET }}$ & $\begin{array}{r}400 \\
-1 \\
\end{array}$ & $\begin{array}{c}500 \\
1\end{array}$ \\
\hline FORMATION & $1^{*} 2^{*}$ & & YAZOO CLAY & & $\begin{array}{l}\text { FOREST } \\
\text { HILL }\end{array}$ \\
\hline $\begin{array}{l}\text { PROVINCIAL } \\
\text { STAGE }\end{array}$ & $3^{*}$ & & JACKSONIAN & & $\begin{array}{l}\text { VICKS- } \\
\text { BUR- } \\
\text { GIAN } \\
\text { (PART) }\end{array}$ \\
\hline
\end{tabular}

SECTION 1-WESTERN MISSISSIPPI

FigURE 14.-Graphic correlation of composited sections 2A (eastern Mississippi) and 3A (western Alabama) vs. section 1 (western Mississippi). As a prefix to the sample numbers of the vertical axis, (E) indicates eastern Mississippi (section 2A) whereas (L) indicates Little Stave Creek (section 3A). Details on the locations and positions of all samples in the diagram were given by Frederiksen $(1969,1980 \mathrm{c})$. The dot enclosed by a triangle is the base of the Moodys Branch Formation, that is, the contact between the Claibornian and Jacksonian Stages; the dot enclosed by a circle is the contact between the Moodys Branch Formation and the Yazoo Clay; the dot enclosed a diamond is the Pachuta Marl Member of sections 2A and 3A and a proposed (Thomas, 1948; Murray, 1961)
Pachuta equivalent in section 1; and the dot enclosed by a square is the top of the Yazoo Clay, that is, the contact between the Jacksonian and Vicksburgian Stages. The solid line forms a leg of the line of correlation connecting the base and top of the Moodys Branch Formation, the dashed line forms two legs of the line of correlation if in fact the Pachuta equivalent is $85 \mathrm{ft}$ above the base of the Yazoo Clay in western Mississippi, and the dotted line is the upper leg of the line of correlation if the ratio of rate of deposition was constant during Yazoo time for the sections forming the two axes of the diagram. Data points are events $(O=$ range base; $+=$ range top) accompanied by event numbers. 
events based on taxa that occur in only one sample, or in a few adjacent samples within the study section, if it is thought that these samples represent a stratigraphic interval bounded below and above by unconformities. Otherwise, events based on rarely observed taxa should probably be ignored for graphic correlation. In short, the more experience the paleontologist has with the occurrences and relative frequencies of the taxa at hand, the more accurate will be the tentative rankings assigned to the observed range bases and tops of the taxa in particular sections.

Because most high rankings are assigned to events associated with abundantly represented, relatively long-ranging taxa, my general conclusion, based on the present study, is that if a tradeoff must be made between numbers of samples to be examined and numbers of taxa to be tabulated, it is better to examine more samples but fewer taxa. Because it is efficient to concentrate on potentially high-ranking events, the first samples to be examined should be those at the base and the top of the study sections, so that one can eliminate from consideration the taxa that range throughout the section.

It is interesting to compare ranking taxa for graphic correlation with ranking them for classical biostratigraphic zonation (McCammon, 1970). For zonation, particularly for establishing range zones, it is preferable to choose taxa having the shortest stratigraphic ranges. Such taxa may also be useful for graphic correlation, because if both a range base and a range top were present within the study section, the number of events would be double that available if only a base or a top were found for the taxon within the section. However, a major advantage of graphic correlation, as pointed out by Shaw (1964), is that the critical part of the range is the base or the top, so that long-ranging taxa may be of great use for correlation even if only one of the two possible range events is represented within the study section.

\section{COMPOSITE STANDARD SECTION}

Plate 17 (in pocket) is the composite standard section for 141 sporomorph OTU's in the Eocene of the eastern Gulf Coast. As previously mentioned, the composite standard section has been divided into approximately 510 composite standard units, but, as will be shown later, these units do not represent equal amounts of geologic time. In plate 17, the time and chronostratigraphic scales and their correspondence to calcareous nannofossil zones and planktic foraminiferal zones are mainly from Berggren and others (1982, 1985). Using the assignment of European stages to planktic fossil zones mainly by Berggren and others (1985), I have shown correlations between these European stages and the Gulf Coast formations and provincial stages. I have relied more on data of calcareous nannofossils than on planktic foraminifers in making these correlations because the nannofossil data from the Gulf Coast are considerably more complete; few if any boundaries between planktic foraminiferal zones have been determined for Eocene strata of the eastern Gulf Coast.

\section{GALCAREOUS MICROFOSSIL ZONES}

The Paleocene-Eocene boundary is taken as the boundary between calcareous nannofossil Zones NP9 and NP10 (see Frederiksen and others, 1982). The Bashi and Hatchetigbee Formations belong mainly to calcareous nannofossil Zone NP10, but the uppermost part may belong to NP11 (Gibson and Bybell, 1981, 1984; Bybell and Gibson, 1985). Siesser (1983) assigned the Bashi-Hatchetigbee interval to NP9, apparently because of the rare occurrence of Discoaster mohleri Bukry \& Percival 1971 in one of his Bashi samples. However, this species has been found to range higher than NP9 (Bybell, oral commun., 1984); furthermore, even the lowermost part of the Bashi contains marker species for Zone NP10 (Bybell, 1980; Gibson and others, 1982; Gibson and Bybell, 1984). Gibson and others (1982), Siesser (1983), and Bybell and Gibson (1985) placed the Tallahatta Formation in Zones NP12, NP13, NP14, and possibly NP15. Thus, as Gibson and others (1982) and Bybell and Gibson (1985) emphasized, the boundary between the lower and middle Eocene falls within the Tallahatta Formation, within the lower part of the Claibornian Provincial Stage. The Little Stave Creek section (section 3B) does not include the lower part of the Tallahatta Formation, which has been cut out there by the Jackson fault. Also, the lower 33-ft interval of the preserved Tallahatta at this location is barren of calcareous nannofossils (Bybell and Gibson, 1985) but probably belongs to NP14 (L.M. Bybell, written commun., 1984). According to Siesser (1983) and Bybell (oral commun., 1984), the Lisbon Formation belongs mainly to Zones NP16 and NP17; at Little Stave Creek, the boundary between these zones is approximately $11 \mathrm{ft}$ (Siesser, 1983) or $23 \mathrm{ft}$ (Bybell, oral commun., 1984) below the top of the Lisbon. Zone NP15 has been identified in the lowermost part of the Lisbon only at two localities in Alabama; Zone NP15 cannot be differentiated in the Lisbon at other localities in the eastern Gulf Coast (Siesser, 1983; Bybell, oral commun., 1984; Bybell and Gibson, 1985). The Gosport Formation, at the top of the Claibornian Stage, belongs to Zone NP17 (Siesser, 1983; Hazel, Edwards, and Bybell, 1984). Note that I follow Toulmin (1962) in placing the contact between the Gosport and Moodys Branch Formations $8 \mathrm{ft}$ lower in the section than Bandy (1949, 
fig. 2); thus, I consider the Gosport to be $11 \mathrm{ft}$ thick rather than $19 \mathrm{ft}$ thick as reported by Bandy (whose contact determination was followed by Bybell, 1975). However, molluscan and echinoid data suggest that the "Scutella bed" traditionally placed at the base of the Moodys Branch Formation in Alabama should instead be considered part of the Gosport Formation (D.T. Dockery III, written commun., 1985); in this view, Bandy's (1949) placement of the Gosport-Moodys Branch contact at Little Stave Creek is better grounded than Toulmin's (1962).

The Bashi Formation and Bashi lithofacies tongues in the Hatchetigbee Formation contain planktic foraminifers of the Morozovella subbotinae Interval Zone of Stainforth and others (1975) (Gibson and Bybell, 1981; Mancini and Oliver, 1981; Gibson and others, 1982). Huddlestun and others (1974) and Hardenbol and Berggren (1978, fig. 6) examined planktic foraminifers from the Tallahatta, Lisbon, and Gosport Formations. Huddlestun and others (1974) placed the Tallahatta in Zone P11, the Lisbon in P12 and P13, and the Gosport in Zone P14. Hardenbol and Berggren (1978) placed a sample of the Tallahatta in Zone P12, several samples from the Lisbon also in $\mathrm{P} 12$, and a sample from the Gosport in Zones P13-P14. If at least the upper part of the Tallahatta does belong to Zone P11, then it would probably also be in Zone NP15 (Curry and others, 1978; Hardenbol and Berggren, 1978; Berggren and others, 1985).

Relatively few papers have been published on agediagnostic calcareous nannofossils and planktic foraminifers in the lower part of the Jacksonian Stage (Moodys Branch Formation and the lower two members of the Yazoo Clay). However, the Moodys Branch belongs to Zone NP17 (Martini, 1971, p. 759; Siesser, 1983), as does the North Twistwood Creek Member of the Yazoo Clay (Siesser, 1983). Zones NP17, NP18, and NP19 have all been identified in the Cocoa Sand Member of the Yazoo (Siesser, 1983). Hardenbol and Berggren (1978, fig. 6) found a planktic foraminifer assemblage of Zones P14-P15 in the Moodys Branch Formation. R.W. Barker (in Blow, 1979, fig. 25) assigned the North Twistwood Creek and Cocoa Sand Members of the Yazoo Clay to planktic foraminiferal Zones P14? and P15. However, the validity of Barker's assignment is uncertain because Waters and Mancini (1982), who restudied planktic foraminifers from the North Twistwood Creek and Cocoa, found specimens of distinctive species too rare to make possible a zonation of the two members.

Siesser (1983) assigned the Pachuta Marl Member of the Yazoo to undifferentiated calcareous nannofossil Zones NP19-NP20; Bybell (1982) placed the upper part of the Pachuta in calcareous nannofossil Zone NP20.
Siesser (1983) also considered the lower part of the Shubuta Member of the Yazoo to belong to Zones NP19-NP20, and he thought some Shubuta samples may be restricted to NP20. He found that the upper part of the Shubuta belonged to NP21. The assignment of the lower part of the Shubuta to NP20 was based on the presence in these strata of rare specimens of Discoaster barbadiensis Tan Sin Hok 1927, Discoaster saipanensis Bramlette \& Riedel 1954, and Reticulofenestra reticulata (Gartner \& Smith) Roth \& Thierstein 1972 , all of which have their range tops in NP20. However, Bybell (oral commun., 1984) considered specimens of these species in the Shubuta to be reworked, and she (1982) found that the Shubuta Member of the Yazoo, as well as the overlying Red Bluff and Bumpnose Formations, all belong to Zone NP21. Keller (1985) assigned the Pachuta Marl Member and at least the lower part of the Shubuta Member of the Yazoo Formation to the Turborotalia cerroazulensis planktic foraminiferal zone. Within this zone, she (and Hardenbol and Berggren, 1978, fig. 6) placed the P16-P17 zone boundary at the Pachuta-Shubuta contact, except at one locality in western Alabama where Keller (1985) identified Zone P17 within the upper part of the Pachuta Member.

\section{STAGE BOUNDARY PROBLEMS}

The position of the Lutetian-Bartonian Stage boundary in the Gulf Coast is uncertain. In southern England, the base of the Bartonian has been more or less defined by the range base of the dinocyst species Rhombodinium draco Gocht 1955 (Costa and Downie 1976; Bujak and others, 1980). In Alabama, the range base of this species is within the Gosport Formation (Hazel, Bybell, and others, 1984); that is why Hazel, Edwards, and Bybell (1984) showed a tentatively drawn Lutetian-Bartonian boundary at the base of the Gosport Formation. On the other hand, if the base of the $R$. draco Zone falls within calcareous nannofossil Zone NP16 (Curry and others, 1978; Berggren and others, 1985), and if the NP16-NP17 boundary is within the Lisbon Formation (Siesser, 1983; Bybell, oral commun., 1984), then the Lutetian-Bartonian boundary should be within the Lisbon, well below the base of the Gosport.

The Bartonian-Priabonian Stage boundary (that is, the boundary between the middle and upper Eocene) more or less coincides with the NP17-NP18 boundary (Berggren and others, 1985) and falls well above the base of the Jacksonian Provincial Stage. According to Siesser's (1983) calcareous nannofossil data, the Bartonian-Priabonian boundary is within the Cocoa Sand Member of the Yazoo Clay. 
EOCENE-OLIGOCENE BOUNDARY

Several paleontologists have suggested that the international Eocene-Oligocene Stage boundary should be defined as coinciding with the JacksonianVicksburgian Provincial Stage boundary in eastern Mississippi or western Alabama (Dockery, 1984; Snyder and others, 1984). However, most paleontologists define the Eocene-Oligocene boundary in terms of calcareous planktic microfossil zones. The position of the Eocene-Oligocene boundary in the eastern Gulf Coast has been studied recently by several workers using planktic foraminifers and calcareous nannofossils (Mancini, 1979; Bybell, 1982; Waters and Mancini, 1982; Bybell and Poore, 1983; Keller, 1985). However, the placement of the boundary in this region is still uncertain, for several reasons. As far as calcareous nannofossils are concerned, the Eocene-Oligocene boundary falls within Zone NP21 and therefore cannot be precisely picked on the basis of these fossils. In eastern Mississippi and western Alabama, the base of Zone NP21 is within the Yazoo Clay, at the contact between the Pachuta Marl and Shubuta Members (Bybell, 1982). However, the base of NP21 is usually only a short stratigraphic distance below the EoceneOligocene boundary (references in Bybell, 1982). Therefore, on the basis of calcareous nannofossils, one would expect to find the Eocene-Oligocene boundary within, rather than at the top of, the Shubuta Member.

As concerns planktic foraminifers, the EoceneOligocene contact in marine sections is picked at the last occurrences of Turborotalia cerroazulensis (Cole) (s.l.) and Hantkenina spp. (Stainforth and others, 1975; Hardenbol and Berggren, 1978). Specimens of these foraminifers are found at least as high as the top of the Shubuta Member of the Yazoo Clay, indicating that the Eocene-Oligocene boundary may coincide with the top of the Yazoo (Mancini, 1979; Waters and Mancini, 1982). However, at least some of the Eocene specimens in the Shubuta Member are reworked (Bybell and Poore, 1983; Keller, 1985). Therefore, Keller (1985), on the basis of planktic foraminifers she considered autochthonous, and disregarding specimens she considered reworked, placed the Eocene-Oligocene boundary within the lower part of the Shubuta Member in eastern Mississippi and western Alabama. An even more confusing problem is the position of the EoceneOligocene boundary in western Mississippi; in fact, the whole question of how to trace the Yazoo members from east to west across Mississippi is very difficult to answer.

The Yazoo Clay is $150 \mathrm{ft}$ thick at the MississippiAlabama State line and thickens to $400-500 \mathrm{ft}$ in western Mississippi (fig. 1). The Shubuta Member, which forms the upper part of the Yazoo, can be seen in outcrops and coreholes thickening markedly from western Alabama into eastern Mississippi (DeVries, 1963; May, 1974; Gilliland, 1980). Geophysical log correlations from eastern Mississippi to central Mississippi suggest, though they cannot prove, that the part of the Yazoo that thickens westward across Mississippi is entirely of Shubuta age (Dockery, 1982, p. 12, 13; Dockery and Siesser, 1984, p. 2). Lithologically, the Yazoo of western Mississippi is monotonous; the members of eastern Mississippi and western Alabama are not obvious in western Mississippi. However, several ledge-forming marl or limestone beds are present within the Yazoo of western Mississippi, and one of these, about $85 \mathrm{ft}$ above the base of the formation, has been thought to correlate with the Pachuta Marl Member to the east (fig. 14; Thomas, 1948; Murray, 1961). What is possibly the same hard bed $55 \mathrm{ft}$ above the base of the Yazoo has been identified on geophysical logs as representing the top of the Pachuta Marl Member in central Mississippi (Dockery, 1982; Dockery and Siesser, 1984). If the Pachuta Marl Member equivalent in western Mississippi is only $85 \mathrm{ft}$ or less above the base of the formation, then most of the Yazoo in western Mississippi must correlate with the uppermost member, the Shubuta, which makes up only about one-fourth of the thickness of the Yazoo near the Mississippi-Alabama State line. Because the upper part of the Shubuta Member to the east is probably early Oligocene in age, the upper part of the Yazoo Clay in western Mississippi would be expected to be early Oligocene also, if the lithologic correlations across Mississippi are correct.

Only three papers have dealt with calcareous microfossils in the Yazoo of central to western Mississippi. Siesser (1983) examined a sample from the Yazoo Clay of Riverside Park, Hinds County, Miss., and assigned the sample to calcareous nannofossil Zone NP18. If correct, this zonal determination is very significant because only about $10 \mathrm{ft}$ of the lowermost Yazoo is exposed at that locality. These strata of NP18 are apparently correlative with parts of the Cocoa Sand Member of the Yazoo to the east (see the section of this paper on "Calcareous Microfossil Zones"); therefore, the lowest two members of the Yazoo in eastern Mississippi and western Alabama apparently are represented by only a very thin sequence in western Mississippi. Two other papers are concerned with the Yazoo section exposed in the Miss-Lite Ready Mix quarry near Cynthia, Hinds County (locality 3 of Frederiksen, 1980c; samples 10656, 10653, and 10649 of fig. 14, this paper). The quarry section is probably about $50-115 \mathrm{ft}$ below the top of the Yazoo, which here is about $380-400 \mathrm{ft}$ thick (Monroe, 1954, pl. 2; Bicker, 1965, pl. 4). Dockery and Siesser (1984) assigned the quarry section to cal- 
careous nannofossil Zone NP21, which would make it correlative with some part of the Shubuta Member to the east. They (and L.M. Bybell, oral commun., 1985) have found the nannofossil species Pemma papillatum Martini ranging throughout the quarry section. Because the range top of this species is within the lower part of the Shubuta Member in eastern Mississippi and Alabama (Bybell, 1982, fig. 7), it appears from the evidence of calcareous nannofossils that the quarry section correlates with the lower part of the Shubuta to the east and therefore is probably late Eocene rather than early Oligocene in age. Keller (1985) examined planktic foraminifers from the Cynthia quarry section and also concluded, on the basis of these fossils, that the quarry section is late Eocene in age. In fact, she thought that the P16-P17 zone boundary is probably within the quarry section because she observed specimens of Globigerina ampliapertura Bolli in the upper part of the quarry section but not in the lower part. If correct, this zonal assignment would mean that the quarry section is correlative with the upper part of the Pachuta Marl Member and with only the lower part of the Shubuta Member of eastern Mississippi and western Alabama. In my opinion, the lack of observed specimens of Globigerina ampliapertura in the lower part of the Miss-Lite quarry section is not significant; I am quite sure that the entire quarry section, which is high in the Yazoo and which belongs to NP21, is correlative with some part of the Shubuta Member to the east and therefore undoubtedly belongs entirely to Zone P17.

Unfortunately, as shown previously, so few sporomorph range bases and tops are present within the Yazoo Clay that sporomorphs cannot be used to correlate the Yazoo members across Mississippi. However, sporomorph relative frequency evidence does indicate that the uppermost Yazoo of western Mississippi, which lacks calcareous fossils, is correlative with the uppermost Shubuta to the east. In eastern Mississippi and western Alabama, the proportion of the pollen species Quercoidites inamoenus rises within the uppermost part of the Shubuta until this species becomes a dominant taxon in the sporomorph assemblages at the top of the Shubuta and in the lower part of the overlying Vicksburgian Stage (Frederiksen, 1980c, fig. 8). In western Mississippi, this rise in the relative frequency of the species is very well shown in the uppermost part of the Yazoo (Frederiksen, 1980c, fig. 8); thus, the uppermost (probably lower Oligocene) part of the Shubuta equivalent is demonstrably present in western Mississippi.

As mentioned previously, the observable thickening of the Shubuta Member from western Alabama to eastern Mississippi and geophysical log correlations westward across Mississippi suggest that at least the upper three-fourths of the Yazoo of western Mississippi is correlative with the Shubuta Member to the east. In order for the calcareous nannofossil, planktic foraminifer, sporomorph, and lithologic correlations all to be correct in western Mississippi, the middle three-fourths of the Yazoo in that area would have to be correlative with perhaps the lower one-third to one-half (that is, the upper Eocene part) of the Shubuta Member to the east, and the upper one-quarter of the Yazoo in western Mississippi would have to be correlative with the upper one-half to two-thirds of the Shubuta; that is, the rate of deposition would have to have slowed considerably in the latter half of Yazoo time in western Mississippi, which seems unlikely because, during the latter part of Yazoo time, western Mississippi should already have been receiving prodeltaic sediments from the advancing Forest Hill delta. Thus, the serious discrepancy between lithologic and fossil correlations westward across Mississippi is currently impossible to resolve.

In summary, the position of the Eocene-Oligocene boundary in the eastern Gulf Coast is still uncertain because (1) the boundary cannot be picked precisely using calcareous nannofossils, (2) in eastern Mississippi and western Alabama, the boundary must be picked on the basis of range tops of planktic foraminifers in strata known to contain reworked specimens of these fossils, and (3) in western Mississippi, calcareous nanno- and microfossil evidence conflicts with lithologic evidence as to the probable position of the boundary. However, the Eocene-Oligocene boundary probably does fall somewhere within the Shubuta Member and its correlative in western Mississippi rather than at the top of the Yazoo Clay. Therefore, plates 17 and 18 (in pocket), which include the entire Jacksonian Stage, do include strata of earliest Oligocene age.

\section{SPOROMORPH RANGES}

The Eocene section of Mississippi contains more terrigenous material and less carbonate than the downdip outcrop of western Alabama (Little Stave Creek) or the sections of eastern Alabama and western Georgia. Furthermore, many OTU's appear to range considerably higher stratigraphically in eastern Mississippi than in Alabama or Georgia. Therefore, I suspect that at least some of these apparent upward range extensions in Mississippi are a result of reworking. For this reason, in plate 17 (in pocket), I have shown upward range extensions in Mississippi as dashed portions of the range lines.

The observed range top of Ephedripites subgenus Spiralipites spp. (OTU 33) in plate 17 is difficult to evaluate because this OTU is present but rare virtually 
throughout the Eocene of the Gulf Coast (Fairchild and Elsik, 1969, p. 84; Frederiksen, 1980c, p. 37), but these Eocene specimens may all be reworked from the Cretaceous and Paleocene. On the other hand, specimens of this subgenus are common and certainly indigenous in some middle and upper Eocene strata of southern California (Frederiksen, 1985); thus, the true range of Ephedripites subgenus Spiralipites spp. in the Gulf Coast is uncertain.

Some OTU's known from the lower Sabinian Stage (upper part of the upper Paleocene) but not observed higher than the upper Sabinian (lower part of the lower Eocene) may be present in the upper Sabinian only as reworked specimens. Among OTU's in this category, Tricolpites asper (OTU 197), Aesculiidites circumstriatus (205), Jarzenipollis trina (99), Favitricolporites baculoferus (243), Labrapollis globosa (119), and possibly Corsinipollenites? verrucatus (129) and Momipites flexus (75) have all been found in the upper Sabinian in other areas of the Atlantic and Gulf Coastal Plains (Tschudy, 1973; Frederiksen, 1979, 1980b), and half a dozen specimens of Sparganiaceaepollenites $\mathrm{cf}$. S. reticulatus (45) were found in the Bashi-Hatchetigbee interval in this study; thus, all these OTU's are reasonably likely to be indigenous to the upper Sabinian in the eastern Gulf Coast. On the other hand, I tentatively conclude that Retitrescolpites anguloluminosus (203), Corollina spp. (35), and Paraalnipollenites confusus (101) have their true range tops in the lower Sabinian (upper Paleocene).

Twenty-four OTU's listed in table 1 do not appear in plate 17, for a variety of reasons. Microfoveolatosporis pseudodentata (OTU 7), Milfordia minima (43), Alnus vera (153), Chenopodipollis spp. (161), Pseudolaesopollis ventosa (227), Symplocos? virginiensis group (287), Bombacacidites nacimientoensis (311), and Ailanthipites berryi (335) all range at least from the upper Paleocene to the lower Oligocene. The positions of the range bases of Sphagnum triangularum (23) and Arecipites rousei (171) are unknown, although their range tops may be significant (fig. 14). The range tops of the Triporopollenites pulcher group (57) and the Triatriopollenites convexus group (59) are not determinable because pollen grains of these OTU's are so abundantly reworked. As for OTU's 13, 53, 127, 139, 151, 209, 263, $273,275,303,309$, and 327 , only one or two specimens of each were found; thus, good range information is lacking for these OTU's.

\section{UNCONFORMITIES}

The Eocene flora is considerably more similar to that of the early Oligocene than to that of the late Paleocene; 61 Eocene OTU's of plate 17 (in pocket) range up into the Oligocene, whereas only 30 are known to range down into the Paleocene. Only 11 Eocene OTU's have range tops near the top of the Eocene, whereas 32 or 33 OTU's have range bases in the lower part of the lower Eocene (in the Bashi-Hatchetigbee interval; the exact positions of range bases within this interval are somewhat uncertain). Therefore, the disconformity between the Paleocene and Eocene in the eastern Gulf Coast is much more distinct in terms of sporomorph ranges than is a possible disconformity between the Eocene and Oligocene in this region. Global drops in sea level seem to have been much greater at the end of the Eocene than at the end of the Paleocene (Vail and Mitchum, 1979). Therefore, if the discontinuities in OTU ranges at the base and top of the Eocene of the eastern Gulf Coast are at all proportional to the hiatuses represented by disconformities at these levels, then the regional rates of subsidence and deposition must have been more influential than eustatic sea level changes in controlling the extent of the hiatuses at the beginning and end of the Eocene in this region. On the basis of calcareous nannofossil and planktic foraminiferal zone determinations, the disconformity at the Paleocene-Eocene boundary in the eastern Gulf Coast is thought to represent a hiatus of $0.5 \mathrm{~m} . \mathrm{y}$. or less (Frederiksen and others, 1982). In drawing plate 18 (in pocket), I assumed that this included a hiatus of 0.2 m.y. of earliest Eocene time.

As previously mentioned, the upper Sabinian BashiHatchetigbee interval is rather distinct in its sporomorph flora from the lower Sabinian (upper Paleocene), but the Bashi-Hatchetigbee is also distinct from the overlying lower Claibornian Stage Tallahatta Formation. Several OTU's are well known to have range tops in the Bashi-Hatchetigbee and in its equivalents in Louisiana and Texas, particularly Thomsonipollis magnifica (137), Triatriopollenites turgidus (73), Interpollis microsupplingensis (145), and Platycaryapollenites triplicatus (85). In addition, many OTU's (many of which have not previously been discussed in published papers) have their range bases in the lower part of the Tallahatta Formation. A disconformity has also been thought to be present at the contact between the BashiHatchetigbee and the Tallahatta (that is, at the contact between the Sabinian and Claibornian Provincial Stages) on the basis of stratigraphic evidence (Stenzel, 1952; Fisher, 1964) and calcareous nannofossil distributions. Zone NP11 has never been identified in outcropping strata in the eastern Gulf Coast (Siesser, 1983; Bybell and Gibson, 1985); thus, in outcrop in this region, a disconformity appears to exist representing a hiatus of at least $1.3 \mathrm{~m} . \mathrm{y}$. (the duration of NP11 time according to Berggren and others, 1985). Where NP12 has not been found in the lowermost outcropping Tallahatta, the disconformity represents a longer hiatus 
(Gibson and Bybell, 1981; Siesser, 1984). However, in the subsurface of Alabama, where Zone NP11 may be present in the uppermost part of the BashiHatchetigbee interval, and where Zone NP12 has been identified at the base of the Tallahatta, the disconformity may represent a hiatus of less than $1 \mathrm{~m} . \mathrm{y}$. (Bybell and Gibson, 1985). As stated, the complete Zone NP11 represents $1.3 \mathrm{~m} . y$. but is found only in a thin stratigraphic section in the eastern Gulf Coast; on the other hand, the complete Zone NP12 represents only 0.9 m.y. but is found in a thick section in the region (at least in the subsurface). Therefore, in drawing plate 18 (in pocket), I assumed that the disconformity between strata containing NP11 and NP12 nannofossils represents a hiatus of 1.0 m.y. of NP11 time.

Another small disconformity is also thought to be present within the lower part of the Tallahatta, where parts of Zones NP12 and (or) NP13 are missing; this disconformity probably coincides with the contact between the Meridian Sand Member of the Tallahatta and the overlying unnamed member of this formation and probably represents a larger hiatus in outcropping sections than downdip, in the subsurface (Bybell and Gibson, 1985). On the basis of graphic correlation plots of microfossil data, Hazel, Edwards, and Bybell (1984) concluded that the missing strata at this disconformity represented the upper part of Zone NP12 and that the duration of the hiatus was about $1.4 \mathrm{~m} . \mathrm{y}$. However, according to Berggren and others (1985), the entire Zone NP12 represents only 0.9 m.y.; therefore, in drawing plate 18 (in pocket), I assumed that the disconformity in the eastern Gulf Coast between strata containing nannofossils of Zones NP12 and NP13 represents a hiatus of NP12 time of only $0.4 \mathrm{~m}$.y. Several of the sporomorph range bases and tops in the middle part of the Tallahatta (pl. 17, in pocket) may correspond with this disconformity.

Many authors (Bandy, 1949; Stenzel, 1952; Toulmin, 1962, p. 24, and 1977, fig. 23; Fisher, 1964; Huddlestun and others, 1974) have suggested the presence of a distinct disconformity between the Tallahatta and the overlying Lisbon Formation. Because of the poor quality of calcareous nannofossil and plank tic foraminiferal assemblages in the uppermost part of the Tallahatta Formation and the lower part of the Lisbon Formation (Bybell and Gibson, 1985), the extent or even the existence of a hiatus at the formation contact cannot be proved. Hazel, Edwards, and Bybell (1984, p. 62), on the basis of calcareous nannofossil distributions, reported that they found "no evidence to support" the presence of this hiatus. However, strata assignable to calcareous nannofossil Zone NP15 appear to be thin in the eastern Gulf Coast, whereas this zone represents one of the longest time intervals of any calcareous nannofossil zone in the lower Tertiary (approximately 3.0 m.y. according to Hazel, Edwards, and Bybell, 1984; 4.6 m.y. according to Berggren and others, 1985). Therefore, much of Zone NP15 is probably missing by disconformity or represents very slow deposition in the eastern Gulf Coast (in drawing pl. 18, in pocket, I assumed that the second of these two possibilities was true because of the difficulty of determining the extent of the disconformity within NP15). On the other hand, a distinct discontinuity in sporomorph ranges is not present at the Tallahatta-Lisbon contact; in fact, in contrast to the contact between the BashiHatchetigbee and Tallahatta, the Tallahatta-Lisbon boundary is not easy to pick on the basis of sporomorphs. Partly this difficulty is due to uncertainty about true range tops of OTU's that appear to range higher in Mississippi than in Alabama or Georgia. The difficulty of picking the Tallahatta-Lisbon contact is also a result of the fact that some OTU's having range bases in the lower part to the Lisbon Formation are rare components of the assemblages there. However, if the Tallahatta-Lisbon contact represents a more or less constant time plane in the eastern Gulf Coast, then the presence of OTU's such as the Siltaria abouziarovae group (229), Eucommia type (tricolpate) (185), Ulmipollenites undulosus (117), and Cupanieidites orthoteichus (259) may prove to be useful for distinguishing the Lisbon from the Tallahatta.

Stenzel (1952), Fisher (1964), and Toulmin (1977, fig. 23) thought that at least two prominent disconformities are present within the Lisbon Formation. The lower of these may correspond to the lithologic and paleontologic break $34 \mathrm{ft}$ above the base of the Lisbon at Little Stave Creek between clayey rocks below, containing Cubitostrea lisbonensis (Harris 1919), and coarsely sandy rocks above that contain Cubitostrea sellaeformis (Conrad 1832) (Bandy, 1949; Toulmin, 1962 ; L.W. Ward, oral commun., 1984). Above this is another possible disconformity within the Lisbon Formation, at a level that corresponds to the contact between the Sparta and Cook Mountain Formations in Texas (Stenzel, 1952; Fisher, 1964; Toulmin, 1977). At Little Stave Creek, this horizon may correspond to the disconformity reported by Bandy (1949, fig. 2) and Toulmin (1962, p. 22) $43 \mathrm{ft}$ below the top of the Lisbon there. Hazel, Edwards, and Bybell (1984) reported that the calcareous nannofossil assemblages within the middle part of the Lisbon were too poor to indicate the presence or absence of one or more disconformities within this formation. Neither of the two possible disconformities in the Lisbon can be identified on the basis of distinct discontinuities in sporomorph ranges (plate 17 , in pocket). The most distinct discontinuity within the Lisbon Formation in plate 17 is at a horizon that is 
58 composite standard units above the base of the formation, where nine OTU's $(107,67,133,183,319,225$, $297,91,49)$ have range tops.

Stenzel (1952), Fisher (1964), and Toulmin (1977) thought that a distinct disconformity separated the Lisbon Formation from the overlying Gosport Formation in Alabama. Hazel, Edwards, and Bybell (1984, p. 63) calculated that this disconformity "may represent a hiatus of at least 0.6 m.y." In drawing plate 18 (in pocket), I assumed that this disconformity represents a hiatus of only $0.3 \mathrm{~m} . \mathrm{y}$. The hiatus is probably small because Zone NP17 represents 2.3 m.y. but includes, in the eastern Gulf Coast, the upper part of the Lisbon, the Gosport, the Moodys Branch, the North Twistwood Creek Member of the Yazoo Clay, and the lower part of the Cocoa Sand Member of the Yazoo.

The Gosport Formation is only $11 \mathrm{ft}$ thick at Little Stave Creek (according to Toulmin, 1962); it could not be differentiated lithologically from the Lisbon in the Albany core, but in westernmost Alabama, the Gosport rapidly thickens and grades into a mainly nonmarine unit, the Cockfield Formation, in Mississippi. Eight OTU's were found in the Gosport-Cockfield interval that were not found in the Lisbon Formation. These range bases may be significant floristically, but specimens of these OTU's are generally rather rare in the Gosport-Cockfield interval and higher samples, and thus they are not of great practical value for distinguishing the Gosport-Cockfield from the Lisbon. As reported by Tschudy (1973), and confirmed by Frederiksen (1980c) and the present study, the range base of Parsonsidites conspicuus (163) is generally a good marker for the lowermost part of the Moodys Branch Formation (and the lowermost part of the Jacksonian Stage) in the eastern Gulf Coast. As will be discussed in more detail in the next section, the formations and members within the Jacksonian Stage can hardly be distinguished on the basis of sporomorphs.

\section{RATE OF DEPOSITION, FLORAL DIVERSITY AND TURNOVER, AND PALEOCLIMATOLOGY}

\section{FLORAL DIVERSITY AND TURNOVER}

Several published papers have presented and discussed quantitative data on diversity changes in Tertiary floras. Cousminer (1961) showed changes in numbers of first and last appearances of sporomorph taxa at the epoch level in the Upper Cretaceous and Cenozoic on the basis of Krutzsch's (1957) data on taxon ranges in central Europe. In the last decade, a series of papers have been written exploring the significance of apparent diversity changes in species of plant megafossils at the period level mainly or entirely in North America
(Niklas, 1977, 1978; Knoll and others, 1979; Niklas and others, 1979; Tiffney, 1981) and worldwide (Niklas and others, 1983; Knoll, 1984). These authors disregarded sporomorph data in their analyses because these fossils are "often difficult to identify successfully below the generic level" (Niklas and others, 1979, p. 9). This statement implies that form-species of, for example, leaves do represent natural plant species, which is not necessarily true (Niklas, 1978, p. 379).

In their papers on apparent changes in plant diversity and rates of evolution, Niklas, Knoll, and Tiffney used citations of taxa in previously published papers as their data base. These authors listed several biases peculiar to this sort of data base that made their data difficult to interpret. Niklas and co-workers also listed some biases in their data that apply to mine as well:

1. Representatives of some taxa are better preserved than others. In my study, lack of preserved pollen of Lauraceae is an important weakness.

2. Fossils of some taxa are more abundantly produced and thus are more likely to be found than others. Among pollen grains, anemophilous forms are much more abundantly produced than zoophilous forms. However, among the angiosperm operational taxonomic units (OTU's) listed in plate 17 (in pocket), I estimate that approximately twothirds of them are zoophilous.

3. Stratigraphic ranges of some taxa may not be well known. In collecting data from citations in published papers, misidentifications of taxa and misdatings of rock units generally result in spurious lengthenings of taxon ranges. In my study, involving a limited number of stratigraphic sections within a rather small region, the samples are generally well dated, but some observed taxon ranges are undoubtedly shorter than the true ranges. However, this is to some extent compensated for by the compositing process of graphic correlation, which tends to increase the observed ranges (Edwards, 1984).

4. Some formations and some taxa have been more intensively studied than others. This is also true of my data, especially insofar as I disregarded certain groups of pollen, particularly some of the tricolpates and tricolporates, which are difficult to classify and identify consistently.

5. The stratigraphic and geochronologic resolution of the data is very important. In the earlier papers of their series, Niklas $(1977,1978)$ and Knoll and others (1979) plotted diversities only at the level of the geologic period. In the later papers of Niklas and others $(1979,1983)$ and Tiffney (1981), the fluctuations in the diversity curves suggest a resolution of several million years, although the raw 
data surely were not good enough to support nearly as good a resolution as that. In comparison with most other fossil plant-bearing sequences, the stratigraphic section that I studied has been uncommonly well dated on the basis mainly of calcareous nannofossils tied elsewhere to radiometric dates. I believe that the formation boundaries in my study area are accurately dated to within several million years. In summary, in my study, the stratigraphic positions of concentrations of range bases and tops and of diversity changes are quite well known, and the radiometric ages of these changes are probably far better known than reported ages of changes based on plant megafossils.

6. The choice of the rank of the taxa tabulated also affects the resolution that can be obtained. Niklas and co-workers used form-species-level data. Some of the OTU's that I listed in table 1 are much broader than form-species level; for compilation of data for plate 18 from plate 17 (both in pocket), I disregarded spores and gymnosperm pollen grains and used all angiosperm pollen OTU's except Platycaryapollenites spp. (OTU 87), Brosipollis, other striate species (135), and Chenopodipollis spp. (161). I also disregarded Retitrescolpites anguloluminosus (203) and Paraalnipollenites confusus (101) because these species probably occur in Eocene strata of the Gulf Coast only as reworked specimens. However, I did include data from the genus OTU's Graminidites spp. (37), Longapertites spp. (177), Proxapertites spp. (179), and Dicolpopollis spp. (183), because these forms have considerable stratigraphic significance even at the genus level. Thus, the diversity and first and last occurrence data in plate 18 are based on ranges of 126 angiosperm OTU's in plate 17.

\section{PREVIOUS PALEOCLIMATIC CONCLUSIONS}

In two early, generalized papers on the early Tertiary climates of the Southeastern United States, Berry (1924, p. 129-133) described the late Eocene climate of the Southeastern United States as being "subtropical," whereas Dorf (1960, map 1) showed this region as being "tropical" at that time. However, the paleoclimatic interpretations of Berry and Dorf are difficult to evaluate because neither author defined what he meant by "subtropical" or "tropical." Axelrod (1966, p. 144) described the middle Eocene climate of Tennessee as being "warm temperate," with a slightly cooler effective temperature but a much smaller annual range of temperature than in present southern Florida. Dilcher (1973, p. 57) more or less agreed with Axelrod; Dilcher considered that in the middle Eocene, Kentucky and Tennessee had a "seasonally dry to slightly moist moisture regime and an equable warm temperate to cool subtropical temperature regime. There were probably frosts in the nearby upland areas that only rarely invaded the lowlands." This would be a climate somewhat like the current climate in southern peninsular Florida and coastal Louisiana (Dilcher, in Frederiksen, 1980a, p. 730). Wolfe (1975a, p. 161; 1975b, p. 271; 1978 , p. 699) thought the middle Eocene climate of the Mississippi Embayment was "dry tropical." He interpreted the Eocene mean annual temperatures of the Mississippi Embayment as fluctuating broadly between $20^{\circ}$ and $28^{\circ} \mathrm{C}$ (Wolfe, 1978 , fig. 1) or between $22^{\circ}$ and $30^{\circ} \mathrm{C}$ (Wolfe and Poore, 1982, fig. 16.1). By comparison, the present mean annual temperatures of $\mathrm{New}$ Orleans and Miami are $21^{\circ}$ and $24^{\circ} \mathrm{C}$, respectively, and mean annual temperatures of $25^{\circ}-28^{\circ} \mathrm{C}$ are found at coastal plain stations in Central America and northeastern South America (Wolfe, 1979, pl. 3). Thus, Wolfe (1978; Wolfe and Poore, 1982) thought that the mean annual temperature of the Mississippi Embayment, at least in the middle Eocene, was considerably warmer than did Axelrod (1966) and Dilcher (1973). All the foregoing paleoclimatic papers were based on plant megafossil data, and Dilcher and Wolfe, in particular, placed the most reliance on shapes, sizes, and margin types of fossil leaves. Elsik (1974a), on the other hand, based his paleoclimatic interpretations of the Eocene of the Gulf Coast on modern climatic affinities of certain plant taxa represented in the rocks by pollen grains. He thought the Eocene climate ranged from warm temperate to subtropical or from cool temperate to warm temperate but did not define these climatic terms. I used the same sorts of criteria as Elsik (1974a) in reconstructing the paleoclimates of the late middle Eocene and late Eocene in the Southeastern United States (Frederiksen, 1980a) and concluded (p. 728) that, during this time interval, the climate was "winter-dry tropical close to the Gulf of Mexico (something like the Florida Keys of today) and marginal humid subtropical on the upper Coastal Plain (something like coastal Louisiana today)"; my climatic terms were taken from Trewartha (1968). Thus, my interpretation of the late middle Eocene to late Eocene climate of the Gulf Coast was about the same as Axelrod's (1966) and Dilcher's (1973) interpretations for the middle Eocene of the same region.

Apparent climatic changes in the Eocene and early Oligocene of the Southeastern United States have been reconstructed by only a few authors. On the basis of fossil leaf data, Wolfe (1978, fig. 1), and particularly Wolfe and Poore (1982, fig. 16.1), inferred that mean annual temperature maxima existed in the upper Mis- 
sissippi Embayment during the first half to two-thirds of the early Eocene, during the second half of the middle Eocene, and in the latter part of the late Eocene; they concluded that mean annual temperature minima were present early in the middle Eocene and in the first half of the late Eocene. Wolfe (1978, p. 699) also concluded that, in the Mississippi Embayment, there was "a pronounced drying trend from the Paleocene into at least the middle Eocene." However, Wolfe had no plant megafossil data for the Oligocene of the Eastern United States. On the basis of pollen, Elsik (1974a) concluded that the Eocene to early Oligocene interval could be divided into four climatic time zones: early Eocene (cool or warm temperate), middle Eocene (warm temperate or subtropical), late Eocene perhaps to earliest Oligocene (cool or warm temperate), and early Oligocene (cool temperate?). Also on the basis of pollen data, I concluded (Frederiksen, 1980a, p. 728) that "lack of change of the sporomorph assemblages suggests that the climate of Southeastern United States did not change appreciably from late in the middle Eocene until nearly the end of the Eocene. Then the climate rapidly became cooler and perhaps drier, a regime that persisted into the early Oligocene."

\section{INTERPRETATION OF PLATE 18}

Plate 18 (in pocket) is a collection of diagrams concerned with geological, botanical, and paleoclimatic aspects of Eocene and earliest Oligocene time in the eastern Gulf Coast. All the diagrams are plotted against the geochronologic (time) scale of Berggren and others (1985), and all the diagrams but the last one are based on data of plate 17 (in pocket). Column 1 of plate 18 shows calculated rates of sediment deposition; column 2 indicates sporomorph diversities; columns 3 and 5 are plots of numbers of range tops and bases, respectively; columns 4 and 6 show calculated rates of last and first appearances of OTU's based on the data of columns 3 and 5; and column 7 reproduces Wolfe and Poore's (1982) diagram of interpreted paleoclimatic trends in the Mississippi Embayment.

Because of uncertainty about the true range tops of OTU's that range higher in eastern Mississippi than in Alabama or Georgia (dashed portions of the range lines in pl. 17), in the numerical calculations for plate $18 \mathrm{I}$ have considered that each of these OTU's has two range tops, but I have counted each of the two possible range tops as having only half the value of the top of a solid range line. For example, I considered the range top of Ulmipollenites krempii (OTU 111) to be "normal"; in contrast, I considered that Pistillipollenites macgregorii (OTU 121) has two possible range tops, one in the middle of the Bashi-Hatchetigbee interval and one near the middle of the Tallahatta Formation, and I assigned each of these two possible range tops only half the "normal" value.

The timing of events (that is, the vertical dimension) in columns 1-6 depends on the accuracy of the time scale of Berggren and others (1985) and on the correctness of the correlations among the time scale, nannofossil zones, and rock units. The lateral dimensions of the curves in columns 2,3 , and 5 do not depend on the time scale; they are presentations of observed data. Therefore they are more likely to be correct than the lateral dimensions of the curves in columns 1,4 , and 6 , which were calculated on the basis of assignments of the rock units to particular time intervals.

Column 1 (the rate-of-deposition curve) is based on thicknesses of stratigraphic units in the composite standard section (pl. 17) and on the geologic time values assigned to the units. The rate of deposition seems to have remained fairly constant during much of the Eocene and earliest Oligocene except during times represented by disconformities and except for several periods of apparently very rapid or slow deposition represented by (1) the lowermost part of the Tallahatta Formation (early NP12 time), (2) the upper part of the Tallahatta Formation and lower part of the Lisbon Formation (Zone NP15 time), and (3) the Cocoa Sand and Pachuta Marl Members of the Yazoo Clay (more or less coincident with Zones NP18-20 time). As stated previously, the lowermost part of the Tallahatta in Alabama and Georgia, representing the early part of NP12 time, is thought to be correlative with the Meridian Sand Member of the Tallahatta in Mississippi (Bybell and Gibson, 1985). The Meridian equivalent in Alabama seems to have been deposited rapidly, according to column 1 of plate 18 . Curiously, the NP12 part of the Tallahatta in Alabama and western Georgia is more clayey, and less sandy, on average, than the overlying NP13 and NP14 parts of the Tallahatta (Bybell and Gibson, 1985), which apparently were deposited more slowly. Therefore, the NP13 and NP14 parts of the Tallahatta may represent intermittent deposition.

As pointed out in the section of the paper on "Calcareous Microfossil Zones," few Tallahatta and Lisbon samples were found by Siesser (1983) and Bybell and Gibson (1985) to belong to Zone NP15. Thus, either deposition was very slow at this time, as implied by column 1 of plate 18, or else there is a distinct disconformity between these two formations.

Slow or intermittent deposition of the calcareous Pachuta strata is not difficult to envision, but slow deposition of the Cocoa Sand Member is unlikely because this member is a very lenticular body. It wedges out to the west into the lower part of the Pachuta Marl Member (Gilliland, 1980) and perhaps also into the uppermost part of the North Twistwood Creek Member 
(DeVries, 1963). To the east, the Cocoa Sand Member thins and wedges out into carbonate rocks of the Crystal River Formation (Murray, 1961). The Cocoa seems to represent a sand fill in a broad submarine depression or north-south-oriented submarine channel and should have been deposited more quickly than the Yazoo clays to the west or the Crystal River carbonate rocks to the east. In plate 18 , I somewhat arbitrarily assigned 2.45 m.y. of deposition time to the Cocoa Sand Member on the basis of Siesser's (1983) statement that various samples from this member belonged to calcareous nannofossil Zones NP17, NP18, and NP19. Because the geologic evidence suggests that the Cocoa was deposited fairly rapidly, I suspect that one or two of these zonal determinations are incorrect. Furthermore, a substantial eustatic drop in sea level apparently took place approximately at the end of NP17 time (Vail and Mitchum, 1979). It is intriguing to speculate that the sand fill forming the Cocoa Sand Member may be associated with this drop in sea level and that a disconformity, perhaps involving much or all of NP18 time, might be associated with the Cocoa horizon in the Yazoo Clay.

Columns 2 through 6 of plate 18 provide data from which to evaluate times and rates of floral change during the Eocene and earliest Oligocene of the eastern Gulf Coast, derived from the OTU range lines in plate 17. None of the data in columns 2-6 of plate 18 can be interpreted directly in terms of particular paleoclimates. However, the maxima in the curves for first and last occurrences probably do represent times of rapid climatic change and (or) floral migration.

In plate 17, 35 significantly different stratigraphic levels were identified, at each of which there was at least one range base (first appearance) and (or) range top (last appearance). The numbers of range bases and tops at each of these levels were counted, and these raw data are shown in columns 3 and 5 in plate 18 . Columns 4 and 6 of plate 18 show rates of angiosperm floral turnover based on these data. In these columns, OTU first and last appearances are expressed as numbers of first and last appearances per million years; the data were averaged over a running 2-m.y. interval in order to smooth the curves and emphasize trends rather than details.

The trends in the diversity curve (column 2 ) are probably essentially correct because, if the true diversity in the Eocene had remained constant through time, the observed diversity would vary to some degree according to the number of pollen grains scanned per sample and the number of samples studied per time interval. However, I studied approximately three times as many samples per million years for the upper Sabinian, Jacksonian, and lower Vicksburgian Stages than for the

TABLE 5.-Number of samples studied per geologic time interval by
Frederiksen (1980c) and in this paper
[Samples from the Vicksurgian Stage, which overlies the Yazoo Clay, are listed in Fred-
eriksen (1980) and are not shown in plate 18, in pocket]

Claibornian Stage (table 5). Therefore, the ratio of observed diversity to true diversity should, if anything, be lower for the Claibornian than for the other stages, and the true diversity peaks within the Claibornian may be more pronounced than the observed peaks shown in plate 18.

However, a weakness of the diversity curve of plate 18 , and indeed of every published floral diversity curve from the lower Tertiary of North America that I know of, is that it assumes that each taxon was present during every time interval within its total range. Thus, the diversity curve would not show exodus and reentry of taxa from and to the region due to possible repeated warm-cool cycles within the Eocene. I did not attempt to compile diversity data separately for the individual samples or for individual time intervals because some time intervals would by chance be represented by many more samples than other intervals; thus, the diversity data would probably be strongly influenced by the number of samples and the taxon richness of individual samples within each interval.

In columns 3 and 5, some indications exist of concentrations of range tops and bases within certain intervals of the composite Eocene section, but these data are difficult to interpret because, for the most part, the numbers of tops and bases at each stratigraphic level seem to fluctuate in a somewhat random fashion throughout the section. Converting these data to rates per million years in columns 4 and 6 emphasizes the times of rapid regional extinction and first appearance of angiosperm taxa during the Eocene and earliest Oligocene. The weakest parts of columns 4 and 6 are at the top and bottom of the diagram because of the averaging over a 2-m.y. interval. For example, in column 4 there seems to be a peak in the rate of last appearances more or less corresponding to the hiatus represented by the unconformity between the Bashi-Hatchetigbee interval and the Tallahatta Formation. However, the position of this apparent peak is stratigraphically too 
high; it can be seen from the data points in column 3 that the high rate of OTU last appearances took place during Bashi-Hatchetigbee time, during the early part of the early Eocene, as some taxa that survived from the Paleocene became extinct not only on the Gulf Coast but probably throughout North America and western Europe (Thomson and Pflug, 1953; Krutzsch, 1966; Hickey, 1977; Tiffney, 1981). At the same time, near the beginning of the Eocene, very rapid immigration and (or) evolution of plant taxa took place in the eastern Gulf Coast (columns 5 and 6) but extending from Bashi-Hatchetigbee to early Tallahatta (probably Meridian Sand Member) time. This is the highest rate of first appearances per million years known for the Eocene of the eastern Gulf Coast. The distinctness of this first appearance event may mean that the disconformity between the Bashi-Hatchetigbee and the underlying upper Paleocene strata represents a longer hiatus than previously thought. However, among the OTU's that first appear in the lower part of the lower Eocene (Bashi-Hatchetigbee interval) in the Gulf Coast are seven that have also been found in the lower Tertiary of Europe. The range bases of these OTU's in Europe are as follows:

Dicolpopollis -Eocene (Krutzsch, 1970a)

Eucommia types-lower Paleocene (Muller, 1981, p. 18, 19 and references therein)

Interpollis microsupplingensis - lower Paleocene (Krutzsch, 1961)

Milfordia hungarica - upper? Paleocene (Krutzsch, 1970a)

Milfordia incerta - lower Paleocene (Krutzsch, 1970a)

Platycarya types-uppermost Cretaceous (Krutzsch, 1970c)

Triatriopollenites turgidus-Paleocene (Thomson and Pflug, 1953)

In short, most of these taxa that are the most useful for differentiating the lower Eocene from the Paleocene in the Gulf Coast probably originated in Europe in the Paleocene or even in the latest Cretaceous and migrated to North America at the very end of the Paleocene or the beginning of the Eocene. The most conspicuous element of the earliest Eocene sporomorph flora is made up by the Platycarya pollen complex (Platycarya megafossil-pollen perplex of Wing and Hickey, 1984); the probable migration of this complex from Europe to North America in latest Paleocene-earliest Eocene time has been well documented (Wing, 1984, and references therein) and agrees well with geological and paleontological evidence that a North Atlantic land bridge existed in the Paleocene and early Eocene between Europe and North America and that this corridor was used in the early Eocene by an unusually large number of terrestrial vertebrate taxa to migrate from continent to continent (McKenna, 1975, 1983). Tiffney $(1980,1985)$ had argued that floral interchange between western Europe and North America must also have occurred during the early Tertiary by way of the North Atlantic land bridge. The concentration of sporomorph range bases in the early Eocene of the eastern Gulf Coast is the best evidence yet presented that this floral interchange took place mainly at the beginning of the Eocene. It now appears that the early Eocene event is the most distinct floral immigration event documented for the Eocene of North America.

Two other important taxa that also arrived on the Gulf Coast near the beginning of the Eocene apparently have not been found in Europe but have a pantropical distribution in the latest Cretaceous and early Tertiary: Proxapertites and Longapertites. The nature of the dispersal event that led to the arrival of these two genera on the Gulf Coast, probably from the Caribbean area, is not known, but it may be connected with plate movements (see, for example, Sykes and others, 1982).

On the basis of published stratigraphic occurrences of plant megafossil species in North America, Tiffney (1981, p. 222) commented on "the Late Paleocene and Early Eocene when a high turnover peak is witnessed against a backdrop of little change in diversity." The present data from the Gulf Coast demonstrate a high rate of plant taxon turnover, at least in the early Eocene, but also indicate that floral diversity was relatively low at the beginning of the Eocene.

The extinction of some Paleocene plant species at the beginning of the Eocene may have been caused by competitive pressure from the Platycarya complex and other new immigrants from Europe and the Caribbean. However, the net effect of the early Eocene event was a rapid rise in plant taxon diversity at the beginning of the Eocene, as shown in column 2.

Note that the exact shape of the diversity curve in Bashi-Hatchetigbee time is somewhat uncertain because many of the range tops and bases shown within this interval are in the "middle sample," which actually represents six samples of uncertain stratigraphic position within the Bashi and Hatchetigbee Formations of Alabama and Georgia (see description of section 4). Also, the exact timing of first and last occurrences during early Tallahatta time is somewhat uncertain because few samples were available from the lower third of the Tallahatta and because of the unconformity between the lower part of the Tallahatta and the remainder of the formation. However, the curvesmoothing produced by the running $2-$ m.y. mean in columns 4 and 6 of plate 18 probably gives a reasonable representation of the timing and rate of floral turnover in the early Eocene of the eastern Gulf Coast. 
The lack of observed range tops and bases within the interval of upper Zone NP12 to lower Zone NP14 is probably at least partly due to the small number of samples available from within this interval. However, above this sample-poor interval, in rocks representing a time span of about 52 to about 45.5-46 Ma, from early Claibornian to late middle Claibornian, the record of first and last appearances show a rather stable rate of immigration and (or) evolution and regional extinction, so that the angiosperm taxon diversity did not change greatly. This period of stable rate of floral turnover was interrupted by a very distinct episode of rapid floral turnover that lasted from about $46 \mathrm{Ma}$ (late middle Claibornian) to $41.5 \mathrm{Ma}$ (latest Claibornian). Within this time interval. there seems to have been a sequence of three constituent events: (1) a concentration of first appearances; (2) a concentration of last appearances; and (3) a second concentration of first appearances. The result of this middle Eocene floral turnover event was that the angiosperm taxon diversity reached a peak at about 45.3-44.2 $\mathrm{Ma}$ and then declined rapidly over the next $2 \mathrm{~m} . \mathrm{y}$.

The initial rise in the rate of first appearances, leading to the diversity maximum, could be interpreted as an event of immigration and (or) of climatic change. No migration route became established with Europe at this time, according to published papers. Furthermore, of the 14 OTU's that have first appearances in the interval of about 46-44.2 Ma (OTU's 215 to $283 \mathrm{in} \mathrm{pl.} \mathrm{17),}$ four or five $(185$ ? $117,29,155,31)$ are known from the lower Eocene or lower middle Eocene of southern California (Frederiksen, 1983, 1985, and unpub. data). Thus, if the burst of first appearances in the eastern Gulf Coast during the interval of about 46-44.2 Ma is at least partly an immigration event, then some of the immigrants may have come from southwestern North America. The first appearance event may have been influenced by an increase in mean annual temperature, according to the leaf-characteristic data of Wolfe (Wolfe and Poore, 1982; here, pl. 18, column 7) in the Mississippi Embayment. However, it is difficult to draw paleoclimatic conclusions from the list of 14 OTU's having first appearances in the interval of interest except that this group includes a modern-looking fagaceous species, Quercoidites inamoenus, which becomes very abundant in the region at about the beginning of the Oligocene, probably under conditions of increased coolness and dryness. A general increase in dryness during the middle Claibornian may be shown by the first appearances of four OTU's of Ephedra $(E$. fusiformis, $E$. claricristata, E. exiguua, $E$. hungarica type) during the interval between 50.3 and $44.6 \mathrm{Ma}$ (pl. 17; these data are not shown in pl. 18, which includes only angiosperm taxa).
The peak in rate of last appearances, during the interval of approximately 45-42 $\mathrm{Ma}$, was presumably due partly to a climatic deterioration because it led to a rapid drop in diversity. However, the high rate of regional extinctions was undoubtedly also due, at least in part, to competitive pressure from the taxa that had evolved and (or) arrived in the region shortly before. Again, it is difficult to categorize the 39-41 OTU's that have last appearances during this time interval except that this group includes prominent holdovers from the Paleocene flora such as Plicatopollis triradiata, Plicatopollis triorbicularis type, Labrapollis globosa, Carya $<29 \mu \mathrm{m}$, and the Triporopollenites palaeobetuloides group; taxa that had first appearances on the Gulf Coast near the beginning of the Eocene, such as Milfordia hungarica, Dicolpopollis spp., Eucommia type, and Longapertites spp.; and many taxa that had first appearances higher in the Eocene section, such as Nuxpollenites spp., Bombapollis texensis, Anacolosidites reklawensis, Malvacipollis cf. M. tschudyi, and several forms of Lanagiopollis.

The second peak in the rate of first appearances, during the interval of about 43-41.5 Ma, coincides with the fall in diversity. I interpret this peak as being due to the immigration and (or) evolution of taxa that were adapted to the new, more severe climate. This interpretation is supported by an examination of the 17 OTU's having first appearances during this time interval (OTU's 131 to 163 at the right end of pl. 17). This group of OTU's includes an unusually large number of taxa probably of herbs or possibly of shrubs-Parsonsidites conspicuus (possibly Apocynaceae or Balanophoraceae), Boehlensipollis hohlii (Elaeagnaceae), Corsinipollenites oculus-noctis (Onagraceae), Graminidites spp. (mainly or entirely Gramineae), and Ruellia? laxa (Acanthaceae). In contrast, the OTU's in the left and middle parts of plate 17, taxa originating in the Paleocene to early middle Eocene, seem to belong mainly to families of trees such as Juglandaceae, Ulmaceae, Bombacaceae, Tiliaceae, Sapotaceae, and Alangiaceae, families which, on the average, would probably thrive best under conditions of warmth and minimal dry seasons. Corsinipollenites oculus-noctis and Ruellia? laxa are known from the lower middle Eocene of southern California (Frederiksen, 1983); thus, a minor amount of immigration from southwestern North America may also be involved in this peak in the rate of first appearances.

The peak in rate of first appearances from about 4341.5 Ma coincides with deposition of the upper part of the Lisbon Formation and the Gosport Formation. It was at this time that a distinct change took place in the vegetation of peat-forming swamps on the Gulf Coastal Plain. During most of the Claibornian, the assem- 
blages of these swamps had been dominated by Fagaceae pollen, whereas during the Jacksonian, the assemblages were dominated by Momipites pollen ( $E n-$ gelhardia group, Juglandaceae); the period of latest Claibornian time seems to have been the time of changeover from the one type of vegetation to the other (Elsik, 1978; Frederiksen, 1981). Because Momipites pollen existed on the Gulf Coastal Plain throughout the early Tertiary, the change from Fagaceae to Momipites pollen domination of the Gulf Coastal Plain peat swamp assemblages was probably due to a rapid climatic change.

The precipitous drop in diversity was reversed at the beginning of Jacksonian time, at about 41.5 Ma (placement of formation boundaries within Zone NP17 is somewhat uncertain). No range tops or bases of angiosperm OTU's were observed within the Jacksonian Stage except at its very top; thus, the angiosperm flora remained remarkably unchanged for a period probably of nearly $5 \mathrm{~m} . \mathrm{y}$., although the floral diversity was at a lower level than at any time since the first half of the early Eocene. It was not until about the middle of Shubuta time, probably at the very beginning of the Oligocene, that significant floral turnover began again (note that because of the 2-m.y. running mean interval, this turnover event is shown in columns 4 and 6 as beginning too soon). It is significant that many more range tops than bases are found in the uppermost Jacksonian Stage; a sudden drop in diversity took place probably at the beginning of the Oligocene. The 10 or 11 angiosperm OTU's that have last appearances in Shubuta time, probably at the beginning of the Oligocene, are pollen forms that are probably nearly all zoophilous and thus are more likely to represent tropical than temperate taxa. The most important of these OTU's is Spinizonocolpites prominatus, produced by the tropical mangrove palm genus Nypa.

The data in columns 3 and 5 suggest that floral turnover might have continued in Vicksburgian time, immediately following Jacksonian time, but currently available data do not answer this question. I did not find any range bases of pollen taxa known from more than a few specimens within the lowest Vicksburgian Stage (NP21) Forest Hill, Red Bluff, and Bumpnose Formations (Frederiksen, 1980c). However, I do not have data from above these formations; thus, I do not know whether any taxa have range tops within or at the tops of these lower Vicksburgian formations.

As pointed out previously (Frederiksen, 1969, 1980a, c; Elsik, 1978), the concentration of OTU range tops within the Shubuta Member is associated with the rapid rise in relative frequency of the fagaceous pollen species Quercoidites inamoenus at the end of Jacksonian and the beginning of Vicksburgian time. The change in the vegetation and the burst of regional extinctions in the eastern Gulf Coast coincide with the Oligocene deterioration of Wolfe $(1971)=$ the terminal Eocene event of Wolfe (1978), first observed in Alaska and the Pacific Northwest, which is thought to have involved a rapid cooling, particularly in winter minimum temperatures (Wolfe, 1978). Frederiksen (1980a) thought that the terminal Eocene event in the Gulf Coast was due to cooling and perhaps drying of the climate. Because the Eocene-Oligocene boundary is now thought probably to be within the Shubuta Member of the Yazoo Clay rather than at its top (see the section of this paper on the "Eocene-Oligocene Boundary"), it now appears that, at least in the Gulf Coast, the "terminal Eocene" event took place entirely at the beginning of the Oligocene and that little if any climatic change can be detected in this region at the end of the Eocene.

\section{COMPARISON WITH OTHER PALEOCLIMATIC DATA}

Wolfe (1978; Wolfe and Poore, 1982) studied morphological characteristics of fossil leaves from the Mississippi Embayment and, on the basis of percentages of leaf taxa having certain characteristics, he produced numerical estimates of Eocene climates of that region. Column 7 of plate 18 (in pocket) is a reproduction of Wolfe's mean annual temperature diagram (in Wolfe and Poore, 1982, fig. 16.1). The vertical bars are the data points; the length of each bar represents the extent of uncertainty of the sample's stratigraphic position. The dashed line is Wolfe's interpretation of the probable temperature trend during Eocene time in the Mississippi Embayment. The increase in mean annual temperature postulated to have taken place from late Paleocene into early Eocene time agrees with the increase in my angiosperm pollen diversity curve, although I think that at least part of the increase in diversity was due to the arrival of immigrant plant taxa from Europe. However, McKenna (1983) thought that the sudden interchange of biota between North America and Europe was due to a rapid warming of climate at the beginning of the Eocene, allowing use of the terrestrial corridor across the North Atlantic which had already been in existence during the late Paleocene. Wolfe's postulated rise in mean annual temperature from the middle of Claibornian to the end of Claibornian time partly coincides with the rise in my diversity curve, but the maximum warmth in Wolfe's curve is at about $41.5 \mathrm{Ma}$ (in the time scale of Berggren and others, 1985), 3.5 m.y. later than the maximum warmth (and (or) rainfall) suggested by my diversity curve. The climatic deterioration shown by Wolfe as lasting from early to middle Jacksonian time is also about $3 \mathrm{~m} . \mathrm{y}$. out of phase with the diversity curve. 
Finally, Wolfe indicated a significant increase in mean annual temperature during the latter half of Jacksonian time in the Gulf Coast, but my diversity curve and first and last appearance data do not support the concept of a climatic change during that time span.

Paleoclimatic comparisons with western Europe are interesting because of the question as to whether climatic changes took place there at approximately the same times as in North America. Collinson and others (1981) presented range charts for pollen genera and for certain taxa of angiosperm fruits and seeds in the Eocene of southern England. These authors concluded (p. 316) that there were "two main periods of floristic change during the Eocene in Britain. The first originated in the Wittering [Formation, late Ypresian] and continued during the Lutetian. The second originated in the uppermost Selsey [Formation, late Lutetian] and is expressed mainly within the Barton and Headon Beds [Priabonian]." Thus, Collinson and others (1981) concluded that cooling during the Eocene in southern England took place relatively slowly over long intervals of time; however, their paleoclimatic interpretation was complicated by some observed floristic changes which were probably responses to ecologic shifts resulting directly or indirectly from rising and falling of relative sea level. In contrast, the angiosperm pollen range tops and bases on which plate 18 is based probably were little affected by sea level changes because these samples came mainly from marine rocks containing representatives of the whole regional flora. Finally, Hubbard and Boulter (1983) illustrated a series of curves representing estimated changes in temperature parameters for much of the Eocene of southern England; their temperature data were based on relative frequency changes of pollen genera through several Eocene sections. They found (p. 147) that "a pronounced and prolonged warming episode occurred in the top of the London Clay and bottom of the Bracklesham Beds [Ypresian] *** and that a second equally pronounced, if more short lived, [warming] event occurred at the bottom of the Headon Beds [middle Priabonian]." In summary, paleoclimatic results from southern England based mainly on palynological data do not agree particularly well with my data from the eastern Gulf Coast except that the data in both regions suggest that the early Eocene may have been warmer than average for the epoch.

\section{COMPARISON WITH MODELS OF EVOLUTION}

The data presented here (pls. 17, 18) have some bearing on the question of whether the Red Queen model (Van Valen, 1973) or the Stationary model (Stenseth and Maynard Smith, 1984) better explains observed patterns of evolution in the fossil record. Both models assume the absence of substantial change in the physical environment and also the lack of a significant influx of immigrants into the ecosystem. In the Eocene of the eastern Gulf Coast, distinct changes in rates of first and last appearance of angiosperm pollen OTU's seem to reflect pronounced changes in the physical environment, no doubt mainly changes in climate, and also, on occasion, establishment or breakdown of migration routes. Thus, most of the Eocene angiosperm record in the study area is so strongly influenced by perturbations originating outside the region that an evolutionary pattern conforming to one model or the other cannot be recognized. However, the lack of discernible evolution among OTU's during the $5 \mathrm{~m}$.y. from the late middle Eocene until the end of the Eocene seems very significant because it is the main tenet of the Red Queen hypothesis that evolution should continue, driven by species interactions, even during times of relative stability of the physical environment. It is true that evolution on the level of biological plant species could have continued during this 5-m.y. time interval and might not be detected in changes of the pollen OTU's because most pollen form-species represent groups of biological species, even entire plant genera. However, it seems unlikely to me that significant evolution, in terms of the two models of evolution, could have taken place during the 5-m.y. interval without changes in the OTU's studied.

Previous tests of the models on the basis of the fossil record have involved oceanic plankters (Hoffman and Kitchell, 1984; Wei and Kennett, 1986), which may evolve and become extinct in different ways and at different rates than terrestrial angiosperms. Vascular plants also respond very differently than animals to certain environmental pressures (Knoll, 1984). In particular, as Knoll (1984, p. 23) pointed out, "relative to animals, plant species are extremely vulnerable to extinction as a result of competition from newly appearing taxa." Thus, if the Red Queen hypothesis is valid, the evolution of plants should perhaps demonstrate this validity more distinctly than might some other types of organisms. The apparent 5-m.y. stasis in evolution of angiosperm taxa during the Eocene of the eastern Gulf Coast therefore seems to offer considerable support to the Stationary model, at least insofar as the two models affect terrestrial angiosperms.

\section{SYSTEMATICS}

Forty-five OTU's are treated in this section, largely in order of OTU number. Authors and dates of publication are provided for fossil generic names, but dates of publication are not given for names of extant genera. With rare exceptions, the year given as part of each 
taxonomic name refers to the date when the name was published, not to a particular paper. Therefore, the "References Cited" do not include references that appear only as parts of taxonomic names.

The following eight new species are formally named, illustrated, and described in this section:

Boehlensipollis verrucata

Brosipollis striata

Celtipollenites gracilis

Corsinipollenites? verrucatus

Lanagiopollis hadrodictya

Retibrevitricolpites simplex

Rhoipites capax

Tetracolporopollenites prolatus

The following new combinations are proposed:

Celtis sabinetownensis (Elsik)

Lanagiopollis crassa (van der Hammen \& Wymstra)

Lanagiopollis cribellata (Srivastava)

Lanagiopollis lihoka (Srivastava)

Lanagiopollis eocaenica (Krutzsch)

Siltaria abouziarovae (Kedves)

Symplocos? virginiensis (Frederiksen)

Triatriopollenites compactus (Gladkova)

Triatriopollenites galiformis (Gladkova)

Triatriopollenites paradoxus (Gladkova)

Triatriopollenites sparsus (Frederiksen \& Christopher)

Triporopollenites infrequens (Stanley)

Triporopollenites pulcher (Simpson)

Ulmipollenites thompsonianus (Traverse)

\section{Genus SPARGANIACEAEPOLLENITES Thiergart 1937}

Sparganiaceaepollenites cf. S. reticulatus

Krutzsch \& Vanhoorne 1977 (OTU 45)

Plate 1, figures 6-9

Sparganiaceaepollenites reticulatus (Dokt.-Hrebn. 1960) emend. et $\mathbf{n}$. comb. Krutzsch and Vanhoorne, 1977, p. 25, 26, pl. 11, figs. 19-21.

Remarks.-The authors of this species are Krutzsch and Vanhoorne (1977). Doktorowicz-Hrebnicka (1960, pl. 44, fig. 234) termed specimens of this species "cf. Sparganium forma reticulata," which is no species name. Furthermore, she did not provide a description of the species.

Specimens of this form from the Eocene of the eastern Gulf Coast are similar to $S$. reticulatus in size (30$40 \mu \mathrm{m}$ ) and size of brochi (about $1 \mu \mathrm{m}$ ), but they have a less distinct annulus than $S$. reticulatus, which Krutzsch and Vanhoorne (1977, p. 26) described as having a "moderate annulus development."

Distribution. - Lower Sabinian (upper Paleocene) to Bashi-Hatchetigbee interval; see discussion of the range top in the section of the paper on "Sporomorph Ranges."

\section{Genus EMMAPOLLIS Krutzsch \& Vanhoorne 1977}

\author{
Emmapollis sp. 1 (OTU 49) \\ Plate 1, figures 13-16
}

Description. -Maximum dimension 27-31 $\mu \mathrm{m}$ (nine measured specimens). Outline oval to irregularly circular. Exine 3-3.5 $\mu \mathrm{m}$ thick, in optical section appearing to consist entirely of very closely packed baculate to slightly clavate elements. In plan view, the structural (or sculptural?) elements form an incomplete simplibaculate reticulum in which the muri are slightly less than $1 \mu \mathrm{m}$ wide. An aperture appearing to consist of a single irregular opening about $3 \mu \mathrm{m}$ wide has been seen in several specimens.

Remarks. -This species is similar to a specimen illustrated by Elsik (1974a, pl. 3, figs. 97, 98) as "Inaperturate (?) pollen of crotonoid type (Euphorbiaceae?)," although Elsik's specimen is larger (about $42 \mu \mathrm{m})$ and has slightly coarser structural-sculptural elements. In Crotonipollis De Lima 1976, the structural-sculptural elements in plan view are wedgeshaped and form groups that roughly enclose lumina but do not form a reticulum.

Distribution. - Upper part of the Tallahatta Formation to lower part of the Lisbon Formation.

\section{Genus DIPORITES van der Hammen 1954 \\ Diporites sp. 1 (OTU 51) \\ Plate 1, figure 17}

Description. -Maximum dimension 15-23 $\mu \mathrm{m}$ (eight measured specimens). The longer axis is usually the one connecting the pores, but in several specimens, the transverse axis is the longer of the two. The exine is thin and psilate to finely punctate.

Remarks. - This species is similar to diporate grains illustrated by Elsik (1974a, pl. 2, figs. 35, 36), which that author (in the plate explanation) termed "Ficus? spp. (Moraceae)." However, the specimens in my material have a much more prominent annulus than Elsik's grains.

Distribution. - I found this species only in the uppermost part of the Tallahatta Formation and the lowermost part of the Lisbon Formation. Elsik (1974a, p. 102) reported similar grains as occurring "sparsely in the Middle and Upper Eocene" of the Gulf Coast.

\section{Genus DIPOROCONIA Frederiksen et al. 1985}

\section{Diporoconia sp. (OTU 53)}

Diporoconia sp. 2. Frederiksen and others, 1985, p. 42, 43, pl. 1, figs. 9, 10.

Remarks. - This specimen, from sample UCR 8095, Lisbon Formation at Little Stave Creek, has been illustrated and described by Frederiksen and others (1985). It has considerable similarity to Diporoconia 
iszkaszentgyoergyi (Kedves 1965) Frederiksen et al. 1985, which has been found in Eocene rocks at many localities in Europe and North America (see Frederiksen and others, 1985).

\section{Genus CASUARINIDITES Cookson \& Pike 1954}

Remarks.-Srivastava (1972) and Frederiksen and Christopher (1978) assigned certain early Tertiary columellate triporate pollen species to Casuarinidites, but several problems exist with this assignment. First, Muller (1981, p. 21, 22) summarized criteria by which Myricaceae and Casuarinaceae pollen can be differentiated especially in scanning and transmission electron micrographs, and he considered that the North American fossil pollen of this type represents Myricaceae, not Casuarinaceae. Second, the type species of Casuarinidites is dissimilar to North American fossil pollen assigned to the genus. Third, Mildenhall and Harris (1971) placed Casuarinidites into synonymy with Haloragacidites Couper 1953. Therefore, North American species previously assigned to Casuarinidites must be transferred to other genera, mainly to Triporopollenites and Triatriopollenites.

\section{Genus TRIPOROPOLLENITES Pflug \& Thomson in Thomson \& Pflug 1953}

Triporopollenites palaeobetuloides group (OTU 55) Plate 2, figures 15,16

Remarks.-This group includes Triporopollenites palaeobetuloides Krutzsch \& Vanhoorne 1977 and $B e$ tula infrequens Stanley 1965 . If the two species could be differentiated consistently, most specimens that I have previously assigned to Betula infrequens (for example, Frederiksen, 1979, 1980b) would belong to T. palaeobetuloides. Betula infrequens has on average a slightly smaller annulus than T. palaeobetuloides and is intermediate in annulus size between $T$. palaeobetuloides and Triatriopollenites convexus Groot \& Groot 1962. The Triporopollenites palaeobetuloides group is generally easy to differentiate from species of Triatriopollenites that were formerly assigned to Casuarinidites. However, because of its distinctly columellate endosexine, especially at the apertures, the Triporopollenites palaeobetuloides group is more likely to have been produced by Myricaceae (like Triatriopollenites) than by Betulaceae.

The morphology and taxonomy of Betula infrequens are somewhat uncertain. Stanley $(1965$, p. 290, 291) described grains of the species as having a vestibulum. Probably for this reason, Rouse and Srivastava (1972) assigned the species to the form-genus Betulaceoipollenites. One problem is that the type species of Betulaceoipollenites Potonié 1960 is not Pollenites bituitus Potonié 1931a (Miocene; weakly punctate) because none of the new species named by Potonié in his 1931a paper were validly published (Frederiksen and Ames, 1979). In his 1931b paper, Potonié named two new subspecies of Pollenites bituitus, $P$. bituitus granifer (Eocene; weakly granulate) and $P$. bituitus excelsus (Miocene; weakly punctate). I suggest that the holotype of the species Pollenites bituitus Potonie $1931 \mathrm{~b}$ be the holotype of $P$. bituitus excelsus Potonie $1931 \mathrm{~b}$, that is, figure 9 of that paper; thus, $P$. bituitus excelsus becomes $P$. bituitus bituitus, and this becomes the type species of Betulaceoipollenites Potonie 1960. The aperture structure of the 1931b holotype is not obvious, but the drawing of it suggests that it is atriate. Potonié (1960, p. 114) did not describe the aperture structure of Pollenites bituitus Potonié 1931a, but his drawing (1960, pl. 7, fig. 142) shows a distinct atrium. Thomson and Pflug (1953, p. 79) also interpreted Pollenites bituitus Potonié 1931a as being atriate and transferred the species to Triatriopollenites. Therefore, Betulaeoipollenites is probably a synonym of Triatriopollenites, not of Trivestibulopollenites as suggested by Jansonius and Hills (1976, card 260).

The specimens attributed to Betulaceoipollenites infrequens (Stanley) Rouse \& Srivastava by Rouse and Srivastava (1972, p. 1179, fig. 64) do not belong to that species but rather to the Paraalnipollenites-Betulaepollenites complex. Questions remain about the morphology of the protologue specimens of Betula infrequens, however. The holotype (Stanley, 1965, pl. 43, figs. 7, 8) appears to be corroded; a second specimen (pl. 43, figs. $9,10)$ appears nearly psilate and shows no exine structure, particularly the presence of columellae; however, the third illustrated specimen (pl. 43, fig. 11), which may be partly corroded, appears to have columellae at the aperture like "Casuarinidites" types of the Northern Hemisphere that are now assigned to Triatriopollenites and Triporopollenites. Columellae particularly at the apertures are typical of Gulf Coast specimens that I have assigned to Betula infrequens (for example, Frederiksen, 1979, 1980b). Also, none of the specimens illustrated by Stanley (1965) seems to have a vestibulum as stated in the description of the species. Therefore, I transfer the species to Triporopollenites as $T$. infrequens (Stanley) n. comb. (basionym: Betula infrequens Stanley, 1965, p. 290, 291, pl. 43, figs. 7-11).

Distribution.-At least from the base of the Tertiary System (Frederiksen, 1979) to the middle of the Lisbon Formation.

\section{Triporopollenites pulcher group (OTU 57) Plate 2, figures 11, 12}

Remarks.-This group consists of three species, Triporopollenites pulcher (Simpson) n. comb. (basionym: Casuarina pulchra Simpson, 1961, p. 433, pl. 10, figs. 1, 2, 4, 7), T. discrepans Frederiksen 1973, and 
T. megarobustus Krutzsch \& Vanhoorne 1977. These species have in common a thick sexine (about $2 \mu \mathrm{m}$ thick), a very thin nexine, and little thickening of the exine at the pores. The endopore is larger than the ektopore but not large enough to be considered as forming an atrium. An atrium seems to be present in at least some of the specimens of $T$. pulcher illustrated by Simpson (1961), but these specimens are corroded, and the endopores of these grains are probably larger than they would be in well-preserved specimens (see Srivastava, 1972 , p. 246).

Distribution.-This pollen group is widely found in the Paleocene Series of the Gulf Coast, but its range top in the Eocene Series is uncertain because it is so often found reworked.

\section{Genus TRIATRIOPOLLENITES Pflug} in Thomson \& Pflug 1953

Remarks.-The following pollen form-species of Myrica and Comptonia found in the Gulf Coast material are transferred to Triatriopollenites because it seems unlikely, at least using the light microscope, that fossil pollen grains can convincingly be assigned to individual modern genera of Myricaceae.

Triatriopollenites compactus (Gladkova) n. comb.

Basionym.-Comptonia compacta Gladkova, 1965, p. 182, 183, pl. 11 , figs. 1,2 .

Triatriopollenites galiformis (Gladkova) n. comb.

Basionym.-Myrica galiformis Gladkova, 1965, p. 167, 168, pl. 3, figs. 5,6 .

Triatriopollenites paradoxus (Gladkova) n. comb.

Basionym.-Myrica paradoxa Gladkova, 1965, p. 163, 164, pl. 2, figs. 1-3.

Triatriopollenites lubomirovae (Gladkova 1965) Kedves 1974 and T. galiformis (Gladkova 1965) $\mathrm{n}$. comb. have both been found in the present material. Triatriopollenites lubomirovae (pl. 2, figs. 2-4) has a slightly thinner exine and a less prominent labrum than T. galiformis (pl. 2, figs. 5-8). Triatriopollenites proprius (Frederiksen 1973) Frederiksen 1980 does not appear to differ significantly from $T$. lubomirovae, and I consider the two species to be synonymous.

Triatriopollenites convexus group (OTU 59) Plate 2, figures 13,14

Remarks. - This group includes Triatriopollenites convexus Groot \& Groot 1962, Triatriopollenites granilabratus (Stanley 1965) Norton in Norton \& Hall 1969, and Trivestibulopollenites fissuratus Frederiksen 1978. All of these species may be conspecific with Triatriopollenites rurensis Pflug \& Thomson in Thomson \& Pflug 1953. Triatriopollenites convexus was described by Groot and Groot (1962) as having an atrium and tumescence, but the only well-preserved grain among the illustrated protologue specimens (Groot and Groot,
1962 , pl. 30 , figs. 6,7 ), which is probably the holotype, is distinctly vestibulate although it is tumescent. Thus, Trivestibulopollenites fissuratus is conspecific with Triatriopollenites convexus. The other illustrated protologue specimens of $T$. convexus are more or less atriate, although because they are corroded the lack of the very thin nexine at the pores in these specimens may well be due primarily to corrosion. However, I have seen wellpreserved specimens of $T$. convexus type in the Brightseat Formation (from which the protologue specimens came; lower Paleocene, Maryland) that may be either vestibulate or atriate. The protologue specimens of $T$. convexus also range from tumescent to annulate, but the more distinctly annulate and labrate forms among these specimens (for example, Groot and Groot, 1962, pl. 30, fig. 9) should be considered as belonging to Triporopollenites infrequens (Stanley 1965) n. comb., with which Triatriopollenites convexus intergrades. Triatriopollenites granilabratus is very similar to $T$. convexus, although the protologue specimens of $T$. granilabratus all seem to be atriate.

In my analyses of lower and middle Eocene sporomorph assemblages for this paper, I differentiated pollen grains of the Triatriopollenites convexusTriporopollenites infrequens complex into three groups, (1) grains having a low labrum that were tumescent, (2) grains having a low labrum that were annulate, and (3) grains having a distinct labrum. Groups 1 and 2 were nearly always found together; therefore, for this paper I have lumped them together as the Triatriopollenites convexus group, which ranges to the upper part of the Claibornian or into the Jacksonian Stages (if these higher ranging specimens are not reworked). On the other hand, the distinctly labrate specimens, now assigned to the Triporopollenites palaeobetuloides group, do not range as high in the section.

Some or all of the Jacksonian specimens assigned to Casuarinidites cf. C. granilabratus (Stanley 1965) Srivastava 1972 by Frederiksen (1980c) belong to the Triatriopollenites convexus group. However, some of the specimens placed in Casuarinidites convexus (Groot \& Groot 1962) Frederiksen \& Christopher 1978 in my other papers belong to Triatriopollenites paradoxus (Gladkova 1965) n. comb. (for example, Frederiksen and Christopher, 1978, pl. 3, fig. 23).

Distribution. - Like the Triporopollenites pulcher group, the Triatriopollenites convexus group is widespread in the Paleocene of the Gulf Coast, but the range top of the OTU in the Eocene of this region is uncertain because specimens are so often found reworked.

\section{Triatriopollenites sparsus group (OTU 69)}

Plate 2, figure 10

Remarks. - This group consists of two species, Triatriopollenites sparsus (Frederiksen \& Christopher) $\mathbf{n}$. 
comb. (basionym: Casuarinidites sparsus Frederiksen \& Christopher, 1978, p. 142, pl. 3, figs. 25-27) and Triatriopollenites pseudoroboratus Krutzsch \& Vanhoorne 1977. The two species are very similar, having a thin, frequently folded exine and a nexine that consists of little more than a line of granules as seen in optical section. T. sparsus is the smaller of the two (about 20-40 $\mu \mathrm{m}$ ) and has weak tumescence at the pores, whereas $T$. pseudoroboratus is larger (50-60 $\mu \mathrm{m})$ and is more annulate than tumescent. The two species intergrade with each other, but most specimens that I have seen in the Paleocene and Eocene of the Gulf Coast have the weak tumescence of $T$. sparsus. This species group is undoubtedly more common in lower Tertiary material of the Gulf and Atlantic Coastal Plains than is known at least from my own records; for example, some specimens from the lower Tertiary of Virginia recorded as Casuarinidites spp. (Frederiksen, 1979, pl. 2, figs. 29-32) are now considered to belong to the $T$. sparsus group.

Distribution. -Paleocene to the top of the Tallahatta Formation; specimens found higher in the Eocene section of the eastern Gulf Coast are considered reworked.

\section{Genera PLATYCARYA Siebold \& Zuccarini and PLATYCARYAPOLLENITES Nagy 1969 emend. Frederiksen \& Christopher 1978}

Remarks._Following Frederiksen and Christopher (1978), I have assigned to Platycarya specimens that are similar in their pseudocolpi to modern pollen of this genus. In this paper, I place all these specimens in OTU 81, termed Platycarya platycaryoides type after the typical species $P$. platycaryoides (Roche 1969) Frederiksen $\&$ Christopher 1978. I assign to the form-genus Platycaryapollenites specimens that have pseudocolpi (particularly, arrangements of pseudocolpi) that are different from those of the modern genus. The practice of assigning Eocene pollen to the modern genus Platycarya has received support from the paper of Wing and Hickey (1984), in which these authors point out that Eocene leaves and fruits of Platycarya type may justifiably be placed in the modern genus.

\section{Genus SUBTRIPOROPOLLENITES Pflug \& Thomson in Thomson \& Pflug 1953 emend. Krutzsch 1961}

Subtriporopollenites nanus (Pflug \& Thomson in Thomson \& Pflug 1953) Frederiksen 1980 (OTU 105) Plate 3, figures 5,6

Remarks. -This is a variable species as regards exine thickness; the main characteristics are small size (less than $25 \mu \mathrm{m}$ ) and the weak expression or lack of columellae. The exine structure cannot be determined from the two photomicrographs of the protologue specimens; therefore, it cannot be determined whether this species is synonymous with Subtriporopollenites urkutensis Kedves 1974. Subtriporopollenites anulatus Pflug \& Thomson in Thomson \& Pflug 1953, S. subporatus Krutzsch 1961, and S. magnoporatus (Pflug \& Thomson in Thomson \& Pflug 1953) Krutzsch 1961 contain rather large grains that have a more or less smooth surface, but in these three species, columellae are distinct.

Distribution.-Uppermost Paleocene (unpublished work of the author) to the lower part of the Tallahatta or possibly to the top of the Tallahatta Formation.

\section{Genus ULMIPOLLENITES Wolff 1934 emend. Srivastava 1969}

Ulmipollenites thompsonianus (Traverse) n. comb. (OTU 113) Planera thompsoniana Traverse, 1955, p. 52, fig. 10(53).

Synonymy. _See Frederiksen (1980c, p. 42).

Remarks. - This species could have been produced by Planera, Zelkova, or some other genus of Ulmaceae that existed during the Eocene.

Distribution.-Ranges from the top of the Tallahatta Formation at least to the lower part of the Vicksburgian Stage in the eastern Gulf Coast; upper part of the Oligocene in Vermont (Traverse, 1955).

\section{Genus CELTIS Linnaeus}

Celtis tschudyi group (triporate) (OTU 123)

Plate 3, figures 12-14

Celtis tschudyi group (multiporate) (OTU 159) Plate 3, figure 15

Remarks.-The Celtis tschudyi group includes the following species:

"Nothofagus" tschudyi Elsik 1974b=Celtis tschudyi (Elsik) Frederiksen, 1980

Probably also the other species of "Nothofagus" named by Elsik in his $1974 \mathrm{~b}$ paper

\section{Celtis texensis Elsik 1974}

Celtis sabinetownensis (Elsik) n. comb. (basionym: Thomsonipollis sabinetownensis Elsik, 1974a, p. 98, pl. 2, figs. 47-49).

Although differences exist among the end members of this group, the species seem to intergrade so much that they are probably impossible to differentiate consistently (see also Frederiksen, 1980c, p. 43). In the present material, most specimens are triporate and most closely resemble $C$. sabinetownensis. The triporate Eocene specimens of the Gulf Coast also resemble Annutriporites rotundus Frederiksen 1983 (Eocene of California) but have a thicker exine $(0.8-1 \mu \mathrm{m})$ and are less distinctly columellate than $A$. rotundus.

Distribution.- The triporate forms range from the Bashi-Hatchetigbee interval to the upper part of the Lisbon Formation, whereas the multiporate forms range from the Bashi-Hatchetigbee to the Shubuta Member of the Yazoo Clay, approximately to the top of the Eocene. 


\section{Genus CORSINIPOLLENITES Nakoman 1965}

Corsinipollenites? verrucatus n. sp. (OTU 129) Plate 4, figures 14-16

Corsinipollenites sp. Frederiksen, 1979, p. 154, pl. 3, figs. 1-4; Christopher and others, 1980, p. 117, pl. 2, fig. 22.

Holotype.-Plate 3, figure 1 of Frederiksen (1979), slide OG $340^{\prime} 2^{\prime \prime}$, coordinates $46.3 \times 97.5$, Aquia Formation (upper Paleocene), U.S. Geological Survey Oak Grove core, Westmoreland County, Va.

Description.-Size 19-27 $\mu \mathrm{m}$ (six measured specimens), holotype $20 \mu \mathrm{m}$. Oblate; outline triangular to rounded triangular with prominent doughnut-shaped annuli. Exine 1-1.2 $\mu \mathrm{m}$ thick; exine stratification obscure; surface densely covered by verrucae $0.7-1.5 \mu \mathrm{m}$ in diameter that are also distinct in optical section; negative reticulum ca. $0.3 \mu \mathrm{m}$ wide. Annuli $2-3 \mu \mathrm{m}$ thick; pores round, $1.8-2 \mu \mathrm{m}$ in diameter.

Remarks.-Corsinipollenites? verrucatus differs from previously described species of the genus because of its distinct verrucae and also because of its small size.

Distribution.-Bashi Formation, Dale County, Ala.; also, upper Paleocene (Aquia Formation) and lower Eocene? (Marlboro Clay), Westmoreland County, Va. (Frederiksen, 1979), and upper Paleocene of Meriwether County, Ga. (Christopher and others, 1980).

\section{Genus BROSIPOLLIS Krutzsch 1968}

Brosipollis striata n. sp. (OTU 133)

Plate 3, figures 23-26; plate 4, figures 1-3

Bursera (Burseraceae). Elsik, 1974a, pl. 3, figs. 79, 80.

Holotype. - Plate 3, figures 23-25, slide UCR 8069(2), coordinates 54.1 $\times 95.7$, Tallahatta Formation, Little Stave Creek, Clarke County, Ala.

Description.-Size 21-26 $\mu \mathrm{m}$ (nine measured specimens), holotype $26 \mu \mathrm{m}$. Oblate; outline round but with prominent labra. Exine 1.2-1.5 $\mu \mathrm{m}$ thick; sexine distinctly perforate in optical section, nexine very thin. In plan view, exine is distinctly but finely striate, the striae parallel with each other to anastomosing; striae and lirae ca. $0.3 \mu \mathrm{m}$ wide. Annuli formed mainly or entirely of sexine, 3.0-4.5 $\mu \mathrm{m}$ thick, imperforate; pores round, $2.5-4.0 \mu \mathrm{m}$ in diameter.

Remarks.-Among species of Brosipollis listed by Krutzsch (1968), only B. striatobrosus (Krutzsch 1961) Krutzsch 1968 is striate, and this species is relatively large $(24-38 \mu \mathrm{m})$ and is vestibulate and tricolporate. Rugulitriporites spp. 1, 2, and 3 of Frederiksen (1983) have lalongate pores or are brevitricolporate and are endannulate rather than annulate. Besides Brosipollis striata, several other species of the genus have also been found in upper Sabinian and Claibornian strata of the eastern Gulf Coast (OTU 135, pl. 4, figs. 4-13).

Affinity. - Probably Bursera (Burseraceae), although Muller (1981, p. 69) considered this assignment "doubtful." The aperture structure in modern Bursera pollen is variable among species of the genus; the main aperture types are elongate-porate, brevicolpate, and brevicolporate (Frederiksen, 1983, p. 84), and labra and endannuli are common. However, I do not know of any modern pollen of the genus that has round pores and annuli.

Distribution.-Bashi-Hatchetigbee interval to the middle part of the Lisbon Formation.

\section{Genus ANACOLOSIDITES Cookson \& Pike 1954}

\section{Anacolosidites sp. 1 (OTU 143) \\ Plate 5, figures 6-8}

Remarks. - The size is about 20-25 $\mu \mathrm{m}$. In this species, the design is very finely reticulate at the corners and poles but is coarser reticulate at the equator midway between the corners than elsewhere. The pores lack the atria of $A$. reklawensis Elsik 1974.

Distribution. - Found only at the top of the Tallahatta Formation and in the lower part of the Lisbon Formation.

\section{Genus MALVACIPOLLIS Harris 1965 emend. Krutzsch 1966 \\ Malvacipollis cf. M. tschudyi \\ (Frederiksen 1973) Frederiksen 1980 (OTU 149)}

Plate 5, figures 10-14

Remarks. - This OTU contains grains that are more coarsely spinate than those of $M$. tschudyi (spines as much as $2 \mu \mathrm{m}$ in diameter at the base) but otherwise are similar to that species.

Distribution. - Lower part of the Tallahatta Formation to lower part of the Lisbon Formation.

\section{Genus CELTIPOLLENITES Nagy 1969 \\ Celtipollenites gracilis n. sp. (OTU 157) Plate 3, figures 7-11}

Holotype.-Plate 3, figures 7, 8, slide UCR 8092(2), coordinates $47.2 \times 106.8$, Lisbon Formation, Little Stave Creek, Clarke County, Ala.

Remarks. - This species was described under the name Subtriporopollenites sp. 1 by Frederiksen (1983, p. 36, pl. 9, figs. 16-19). Three specimens had been found in the Eocene of the San Diego area; I found nine more specimens in the Eocene of the Gulf Coast, and Subtriporopollenites sp. of Potter (1976, pl. 4, figs. 104, 105) may also belong to this species. The known size range (maximum grain dimension) is 18-29 $\mu \mathrm{m}$. Grains of this species are rather small in size; the main characteristic of the species is the distinctly and finely columellate sexine and the very thin nexine that may be discontinuous. Both 3- and 4-porate forms are found; the holotype is 4-porate. Subtriporopollenites anulatus anulatus Pflug \& Thomson in Thomson \& Pflug 1953 is generally larger and has a thicker exine and a rela- 
tively thicker nexine. Subtriporopollenites constans constans Pflug in Thomson \& Pflug 1953 sensu Kedves 1974 probably is more coarsely columellate. The Celtis tschudyi group (OTU's 123, 159) has larger pores and more distinct endannuli and is less distinctly columellate. The epithet gracilis (Latin, "thin") refers to the thin exine in this species.

Distribution. - Upper part of the Bashi-Hatchetigbee interval to the upper part of the Lisbon Formation.

\section{Genus ROUSEA Srivastava 1969}

Rousea monilifera type (OTU 195)

Remarks. -Most specimens of Rousea monilifera Frederiksen 1980 are tricolpate, but some are weakly or even distinctly tricolporate. The tricolporate forms intergrade with, or are conspecific with, specimens termed Amanoa type (Euphorbiaceae) by Elsik (1974a, pl. 4, figs. 100-103) and Elsik and Dilcher (1974, pl. 30, figs. 164-168). In this paper, I have grouped all these forms together as $R$. monilifera type. They should probably all be considered one form-species.

Distribution. - Middle of the Tallahatta Formation at least to the lower part of the Vicksburgian Stage.

\section{Genus RETIBREVITRICOLPITES van Hoeken-Klinkenberg 1966}

Retibrevitricolpites simplex n. sp. (OTU 207)

Plate 7, figures 2-10

Holotype.-Plate 7, figures 2, 3, slide UCR 8099(2), coordinates $63.6 \times 105.0$, Lisbon Formation, Little Stave Creek, Clarke County, Ala.

Description.-Size ca. 21-23 $\mu \mathrm{m}$ (six specimens); oblate, more or less round in polar view. Exine 1-1.5 $\mu \mathrm{m}$ thick; ektosexine and endosexine each about the same thickness; nexine very thin. Ektosexine distinctly perforate in optical section, appearing more distinctly columellate than the endosexine. In plan view, exine is distinctly granulate to finely reticulate. Brevicolpate or perhaps lolongate-porate; sides of colpi not different from the remainder of the exine.

Remarks.-Retibrevitricolpites catatumbus Gonzáles Guzmán 1967 is similar but is probably tricolporate and has costae colpi.

Distribution. - Middle part of the Tallahatta Formation to the upper part of the Lisbon Formation.

\section{Genus TETRACOLPOROPOLLENITES Pflug \& Thomson} in Thomson \& Pflug 1953

Tetracolporopollenites megadolium types

(short colpi, OTU 221)

Plate 8, figure 16

(long colpi, OTU 223)

Plate 8, figures 17,18

Remarks. - In my work on the Jacksonian and adjacent strata of the eastern Gulf Coast (Frederiksen, 1980c), I assigned all tricolporate sapotaceoid specimens to Tetracolporopollenites megadolium (Potonié) Frederiksen 1980 (the author of the species is Potonié 1934, not Potonié 1931a; see Frederiksen and Ames, 1979). In the present study, I split this species into two types, those having short and those having long colpi. The short-colpi forms are the tricolporate version of the Tetracolporopollenites brevis type, and the long-colpi forms are the tricolporate version of the Tetracolporopollenites lesquereuxianus type.

Distribution.-Forms having short colpi and long colpi both range from the lower part of the Tallahatta Formation at least as high as the lower part of the Vicksburgian Stage.

Tetracolporopollenites prolatus n. sp. (OTU 225)

Plate 8, figures $10-15$

Holotype. - Plate 8, figures 10, 11, slide R1155(3), coordinates $50.3 \times 110.5$, Zilpha Clay, Panola County, Miss.

Description.-Polar axis 21-28 $\mu \mathrm{m}$ (10 measured specimens), holotype $22 \mu \mathrm{m}$. Prolate; ends rather narrowly rounded; oval in equatorial view except that the sides typically bulge outward at the ora. Exine 1.5-2 $\mu \mathrm{m}$ thick at the poles, thinning slightly toward the equator. Exine composed of an outer indistinctly to distinctly perforated sexine and an inner more or less structureless layer (nexine?); the two layers are of approximately the same thickness. Tricolporate; colpi narrow and long, nearly reaching the poles; cavernae or costae colpi poorly developed. Ora lalongate, 1.52×4-6 $\mu \mathrm{m}$, bordered by thick endannuli.

Remarks. - This species is distinguished by its shape, which would be nearly perprolate if it were not for the bulging ora, and by its tricolporate apertures. Chrysophyllum? brevisulcatum (Frederiksen 1973) Frederiksen 1980 is smaller, typically straight-sided, and more or less imperforate.

Distribution.-Lower part of the Tallahatta Formation to the lower part of the Lisbon Formation.

\section{Tetracolporopollenites brevis type (OTU 339)}

Plate 16, figures 12,13

Remarks. - This OTU is for tetracolporate sapotaceoid pollen grains that have relatively short colpi like T. brevis Frederiksen 1980.

Distribution. - Bashi-Hatchetigbee interval at least to the lower part of the Vicksburgian Stage.

Tetracolporopollenites lesquereuxianus type (OTU 341)

Plate 16, figures 14-16

Remarks. - This OTU is for tetracolporate sapotaceoid pollen grains that have relatively long colpi 
like T. lesquereuxianus (Traverse 1955) Frederiksen 1980.

Distribution. - Lower part of the Tallahatta Formation at least to the lower part of the Vicksburgian Stage; upper Oligocene of Vermont (Traverse, 1955).

\section{Genus SILTARIA Traverse 1955 \\ Synonym.-Intrabaculitricolporites Kedves 1978.}

Siltaria abouziarovae group (OTU 229)

Plate 8, figures 19-22

Remarks. - This group includes two species, Cyrillaceaepollenites kedvesii Frederiksen 1980 and Siltaria abouziarovae (Kedves) n. comb. (basionym: Intrabaculitricolporites abouziarovae Kedves, 1978, p. 53, 54, pl. 11, figs. 6-11; fig. 16). I am now referring to $S$. abouziarovae the specimens assigned previously (Frederiksen, 1980c) to Siltaria pacata (Pflug in Thomson \& Pflug 1953) Frederiksen 1980. The protologue specimens of $S$. pacata lack the dark strips bordering the colpi (cavernae, according to Kedves, 1978) and the tendency toward geniculate colpi that are found in $S$. abouziarovae and in the Gulf Coast specimens. The main difference between $S$. abouziarovae and $C$. kedvesii is that the first of these species has rather distinct columellae whereas the second species lacks them. However, in practice this is a difficult distinction to maintain without constant recourse to highmagnification oil immersion lenses. Therefore, I have grouped the two species together in this study. Most specimens of this group in the Eocene of the eastern Gulf Coast do have columellae.

Distribution. - Lowermost part of the Lisbon Formation at least to the lower part of the Vicksburgian Stage.

\section{Genus RHOIPITES Wodehouse 1933}

Rhoipites capax n. sp. (OTU 247)

Plate 13, figures 13, 14; plate 14, figures 1-7

Holotype.-Plate 13, figures 13, 14, slide UCR $8080(2)$, coordinates $55.7 \times 97.2$, Lisbon Formation, Little Stave Creek, Clarke County, Ala.

Description. - Length of polar axis 37-52 $\mu \mathrm{m}$, mean $44 \mu \mathrm{m}$ (17 measured specimens), holotype $50 \mu \mathrm{m}$. Spheroidal to subprolate; outline in equatorial view oval with broadly rounded ends; outline in polar view trilobate. Exine 3-4.5 $\mu \mathrm{m}$ thick. Distinctly and coarsely columellate; ektosexine generally slightly thicker than nexine; endosexine very thin, typically only $0.1-0.2 \mu \mathrm{m}$ thick; columellae appear nearly gemmate rather than clavate in optical section. In plan view, exine is coarsely reticulate, muri simpli- to duplibaculate and $0.8-1.5 \mu \mathrm{m}$ wide, lumina generally 3-4 $\mu \mathrm{m}$ in diameter, brochi 4-6 $\mu \mathrm{m}$ in diameter. Some specimens have a somewhat broken reticulum, and in these specimens some muri are replaced by somewhat scattered individual columellae (pl. 14, fig. 7). Near the colpi, the lumina may be smaller than $1 \mu \mathrm{m}$, but mainly the reticulum is replaced there by granulate strips bordering the colpi. Colpi long, nearly the full length of the grain, bordered by distinct costae colpi that are 2-4 $\mu \mathrm{m}$ wide on either side of the colpus at the borders of the ora, narrowing toward the poles. Ora distinct, round to somewhat lalongate, maximum dimension 6-7.5 $\mu \mathrm{m}$, encircled by broad but somewhat indistinct endannuli $2-3 \mu \mathrm{m}$ wide.

Remarks. - This species is characterized by its very coarse reticulum ("capax," Latin for roomy, spacious, referring to the lumina) and generally prolate spheroidal to subprolate shape. Rhoipites capax has broader muri than the Amanoa types of Elsik (1974a, pl. 4, figs. 100-103) and much more distinct ora than Rousea monilifera Frederiksen 1980, and it is less prolate than Rhoipites latus Frederiksen 1980.

Distribution.-Middle of the Tallahatta Formation to the upper part of the Lisbon Formation.

\section{Genus BOEHLENSIPOLLIS Krutzsch 1962 emend. Frederiksen 1983}

Boehlensipollis aff. B. granulata Frederiksen 1983

Plate 10, figures 11-13

Remarks. - This specimen is very similar to $B$. granulata except that the colpi are so indistinct that their length cannot be accurately determined; they may extend to the pole on each face. In Boehlensipollis granulata, the colpi extend nearly but not entirely to the pole on each face.

Distribution. - The specimen is from the Lisbon Formation in the Albany core.

\section{Boehlensipollis verrucata n. sp. (OTU 263)}

Plate 10, figures 9, 10

Boehlensipollis sp. 2. Frederiksen, 1983, p. 62, pl. 17, figs. 26-28.

Holotype.-Plate 17, figures 26-28 of Frederiksen, 1983, slide SDSU 2329(1), coordinates $38.9 \times 105.0$, Ardath Shale (lower middle Eocene), San Diego, Calif. (see Frederiksen and others, 1983, p. 15).

Description. - Size 33-39 $\mu \mathrm{m}$ (two specimens), holotype $39 \mu \mathrm{m}$. Outline triangular with nearly straight sides. Exine 2.5-2.8 $\mu \mathrm{m}$ thick; sexine ca. twice as thick as nexine; sexine appears coarsely clavate in optical section. In plan view, exine is densely verrucate; a negative reticulum is present. Colpi narrow; thickened margines indistinct or absent. Heteropolar; on one face, colpi extend to the pole; on the other face, colpi are only 14-15 $\mu \mathrm{m}$ long. Ora 3-5 $\mu \mathrm{m}$ in diameter; atria indistinct because sexine is torn at the corners. 
Remarks.-These two specimens are very similar. Boehlensipollis hohlii Krutzsch 1962 and B. granulata Frederiksen 1983 are granulate in design.

Distribution.-The single Gulf Coast specimen is from the upper part of the Lisbon Formation at Little Stave Creek.

\section{Genus SYNCOLPORITES van der Hammen 1954}

Syncolporites? sp. 1 (OTU 267)

Plate 9, figures 20-23; plate 10, figures 1-4

Description.-Size 29-37 $\mu \mathrm{m}$ (seven specimens); oblate, outline rounded triangular. Exine $2 \mu \mathrm{m}$ thick in the intercolpium, distinctly tectate and columellate; ektosexine and endosexine are about the same thickness, and each is slightly thicker than the nexine. Nexine thickens greatly around the ora, forming endannuli ca. $4 \mu \mathrm{m}$ thick; sexine pinches out over the endannuli and is absent at the ora. Colpi meet at the pole on one face but are absent on the other; they are bordered by smooth costae colpi apparently formed of nexine. Design of exine is punctate to very finely reticulate.

Remarks. - The thick endannulus and colpi on only one face are characteristic of the species.

Distribution. - The OTU is known only from the Lisbon Formation.

\section{Syncolporites sp. 2 (OTU 269)}

Plate 8, figures 27, 28; plate 9, figures 1-4

Remarks. - This species is distinguished by its round to somewhat trilobate shape in polar view, very fine reticulum, and colpi that are very narrow and lack margines; however, both the sexine and nexine are thickened at the equator, where ora presumably are located. The most similar form is Porocolpopollenites sp. 1 of this paper, which has short colpi.

Distribution.-Bashi-Hatchetigbee interval to the top of the Lisbon Formation.

\section{Genus POROCOLPOPOLLENITES Pflug in Thomson \& Pflug 1953}

Remarks. - As many authors have stated (for example, Thomson and Pflug, 1953; Traverse, 1955; Frederiksen, 1980c; Muller, 1981), most form-species of Porocolpopollenites and Symplocoipollenites can be assigned with little doubt to the family Symplocaceae. Some authors consider this family to contain only one genus, Symplocos, but others recognize two, Symplocos and the small genus Cordyloblaste (for example, Willis, 1973). Furthermore, it may well be that if leaves, fruits, and wood were taken into account, the fossils might have to be assigned to extinct genera of the family. Rather than transfer symplocaceous pollen form- species from Symplocos to Porocolpopollenites, I have chosen to indicate doubt as to the exact generic assignment of the fossils by following the generic name with a question mark. Species that are less certain to belong to the Symplocaceae are assigned to Porocolpopollenites.

\section{Porocolpopollenites sp. 1 (OTU 293)}

Plate 8, figures 23-26

Remarks. -This OTU is the same as Symplocospollenites sp. illustrated by Tschudy (1973, pl. 2, fig. 23) and possibly Porocolpopollenites sp. illustrated by Elsik (1968a, pl. 28, fig. 15). I have seen too few specimens to understand the nature of the apertures, particularly of the ora, and the range of variation of specimens that should be assigned to this species.

Distribution. - Lower part of the Bashi-Hatchetigbee interval to the upper part of the Tallahatta Formation. Tschudy's (1973) illustrated specimen is from the Reklaw Formation (Tallahatta correlative) of Texas.

\section{Genus SYMPLOCOS Jacquin}

\section{Symplocos? virginiensis group (OTU 287)}

Plate 9, figures 7,8

Remarks. - This group includes Symplocos? virginiensis (Frederiksen) n. comb. (basionym: Porocolpopollenites virginiensis Frederiksen, 1979, p. 161, pl. 4, figs. 13-18), Symplocos? contracta Frederiksen, 1980, and probably one or two additional species or similar morphotypes. The main described differences between Symplocos? virginiensis and S.? contracta are that $S$.? virginiensis has an atrium and is finely reticulate whereas $S$.? contracta has a narrow vestibulum and is finely foveolate. However, some protologue specimens of $S$.? contracta seem to have an atrium or postatrium, and the distinction between finely foveolate and finely reticulate exine design patterns is difficult to make consistently. Therefore, the two species may well be conspecific. However, Christopher and others (1980, p. 117) observed that, in upper Paleocene material from Georgia, "two distinct morphotypes could be consistently recognized, both of which fall under the circumscription of Porocolpopollenites virginiensis. The distinction between the two morphotypes is based on size and thickness of the nexine." This group probably also includes Porocolpopollenites sp. 2 of Chateauneuf (1980).

Distribution.-Lower Sabinian (upper Paleocene) at least to the lower part of the Vicksburgian Stage.

\section{Symplocos? sp. 1 (OTU 289)}

Plate 9, figures 13-19

Description.-Size 21-30 $\mu \mathrm{m}$ (three specimens); shape triangular, sides nearly straight. The nexine is 
distinct and dark; the sexine is lighter colored and finely reticulate. At the apertures, the sexine thins, but the nexine splits, forming the lower layer of the exine at the pore and also forming a thick layer under the vestibulum.

Distribution. - Found only in the lower part of the Lisbon Formation.

\section{Genus LANAGIOPOLLIS Morley 1982}

Remarks.-Lanagiopollis contains pollen grains of Alangium type (Alangiaceae) that are reticulate or rugulate; Alangiopollis Krutzsch 1962 emend. Morley 1982 contains Alangium type pollen grains that are striate or retistriate. I also include in Lanagiopollis the fossil pollen of Pelliceria (Theaceae or Pelliceriaceae) type; see discussion of the Lanagiopollis crassa type below.

The following species are transferred to Lanagiopollis; the alangiaceous morphology of Srivastava's (1972) two species of Margocolporites was discussed by Frederiksen (1983, p. 73, 74).

Lanagiopollis crassa (van der Hammen \& Wymstra) n. comb. Basionym.-Psilatricolporites crassus van der Hammen \& Wymstra, 1964, p. 237, pl. 1, figs. 1-4.

Lanagiopollis cribellata (Srivastava) n. comb. Basionym.-Margocolporites cribellatus Srivastava, 1972, p. $260,262,264$; pl. 19, figs. 1-8; pl. 20, figs. $1,2$.

Lanagiopollis lihoka (Srivastava) n. comb.

Basionym.-Margocolporites lihokus Srivastava, 1972, p. 264, pl. 20, figs. 3-5.

Lanagiopollis eocaenica (Krutzsch) n. comb.

Basionym.-Alangiopollis eocaenicus Krutzsch, 1969, p. 474, 475 , pl. 3 , figs. $1-12$; text-figure 6 .

\section{Lanagiopollis crassa type (OTU 295)}

Plate 11, figures $10-16$

Remarks. - This OTU includes pollen similar to Lanagiopollis crassa (van der Hammen \& Wymstra) $\mathbf{n}$. comb. This species was described by van der Hammen and Wymstra (1964) and by Germeraad and others (1968, p. 330, 332; pl. 16, figs. 1,2 ) and was considered by Wijmstra (1968) and by Graham (1977) to have been produced by Pelliceria (Theaceae or Pelliceriaceae; spelling follows Willis, 1973). Tomasini-Ortiz and Martinez-Hernandez (1984) split Pelliceria-like specimens from the Eocene and Oligocene of eastern Mexico into two groups, which they termed Pellicieroipollis spp. and Psilatricolporites crassus, and which they attributed to Theaceae and Clethraceae, respectively. Graham (1977; written commun., 1985) stressed the great morphological variability of modern pollen of the monotypic genus Pelliceria; therefore, both groups of Pelliceria-like specimens of Tomasini-Ortiz and Martinez-Hernandez (1984) probably belong to Pelliceria and to the form-species Lanagiopollis crassa.

Enough variability exists among modern and fossil pollen grains of Alangium (Reitsma, 1970; Morley,
1982) and Pelliceria (van der Hammen and Wymstra, 1964; Germeraad and others, 1968; Wijmstra, 1968; Graham and Jarzen, 1969; Graham, 1977) that it may be difficult to be positive that a particular specimen belongs to the one genus or the other. However, the most definitive feature of Pelliceria pollen seems to be that it has broad, thick endannuli; in polar view (the normal orientation of the grains), the nexine forms the endannuli by means of distinct tumescence. In Alangium pollen, by contrast, the nexine often thins toward the apertures, even though it may again thicken abruptly close to the apertures to form endannuli. A second useful difference is that Pelliceria pollen lacks thickened colpi margines, whereas thickened margines are common in Alangium pollen. In terms of Gulf Coast fossil alangiaceous pollen, the species most similar to Lanagiopollis crassa is L. cribellata (Srivastava) n. comb. (pl. 11, fig. 17). L. cribellata has a thinner exine (commonly less than $2 \mu \mathrm{m}$ thick in the mesocolpium), a relatively thicker sexine (ca. twice as thick as the nexine in the mesocolpium), and the exine thins from the center of the mesocolpium toward the edge of the thickened margo. A Gulf Coast Eocene pollen grain very similar to modern specimens of Pelliceria was illustrated by Elsik (1974a, pl. 3, fig. 93). The Gulf Coast specimens of $L$. crassa type found in the present study do not as obviously belong to $L$. crassa sensu stricto, although Germeraad and others (1968) emphasized the variability of the species. In my specimens, the exine is 2-3.2 $\mu \mathrm{m}$ thick; the sexine and nexine are each about the same thickness in the center of the mesocolpium; and the nexine generally thickens toward the apertures as seen in polar view, forming a tumescence. At some apertures in some specimens, the nexine seems to thin or remain constant in thickness toward the apertures, but at these apertures it appears that the nexine is split, forming a kind of vestibulum within the nexine.

Although fossil pollen of Alangium and Pelliceria can probably be distinguished, it does not seem worthwhile to have separate form-genera for the two types. The type specimen of Pellicieroipollis Sah \& Kar 1970 "is almost certainly a pollen grain of Alangium" (Muller, 1981, p. 37).

Distribution. - Lower part of the Tallahatta Formation to the middle part of the Lisbon Formation of the eastern Gulf Coast. Specimens were also reported from the Eocene perhaps of Texas by Elsik (1974a), but no occurrence data were given for the species by that author.

\section{Lanagiopollis eocaenica type (OTU 297)}

Plate 12, figures 9, 10; plate 13 , figures $1-3$

Remarks. - This OTU includes pollen grains similar to Lanagiopollis eocaenica (Krutzsch) n. comb. This 
species was described by Krutzsch $(1969$, p. 474, 475) as follows (translated):

A medium-sized species of Alangiopollis with reticulate-columellate sculpture/structure; exine in the intercolpium at the equator ca. 2$3.5 \mu \mathrm{m}$ thick, having two wall layers (sexine:nexine ratio $3-4: 2$ ). Length of colpi as much as $2 / 3$ polar axis; endopores ca. $4 \times 7 \mu \mathrm{m}$ large. Polar axis fluctuating from mainly less than the equatorial axis to (less frequently) also larger than the equatorial axis. Therefore, grains are found in both polar and equatorial view. Overall size (equatorial axis $\times$ polar axis) ca. $35-(40)-45 \times 20$ to nearly $50 \mu \mathrm{m}$.

Krutzsch's (1969, text-figure 6a) sketch of the reticulum shows it as being simplibaculate; it is difficult to determine the nature of the muri from the photomicrographs, but some muri of the holotype appear duplibaculate. The brochi are 1.5-2 $\mu \mathrm{m}$ in diameter. Grains of $L$. eocaenica type from the Gulf Coast are generally similar to the protologue specimens of the species except that the Gulf Coast specimens have dupli- to polybaculate muri.

Distribution.--Lower part of the Tallahatta Formation to the middle part of the Lisbon Formation.

Lanagiopollis hadrodictya n. sp. (OTU 299)

Plate 13, figures 4-12

Alangiopollis sp. Frederiksen, 1980c, p. 58, pl. 14, figs. 7, 8.

Holotype.-Plate 13, figures 4-6, slide AC 396' (1), coordinates $52.8 \times 100.0$, Lisbon Formation, Albany core, Dougherty County, Ga.

Description.-Equatorial axis 33-42 $\mu \mathrm{m}$ (12 measured specimens), mean $37 \mu \mathrm{m}$, holotype $36 \mu \mathrm{m}$; polar axis slightly larger to slightly smaller than equatorial axis, but most specimens lie in polar view and therefore are probably oblate spheroidal. Outline in equatorial view oval, with broadly rounded poles, to round; outline in polar view trilobate. Exine 2.5-5.5 $\mu \mathrm{m}$ thick, mainly 3-4 $\mu \mathrm{m}$ thick, apparently thickest at the poles. Distinctly and coarsely columellate in optical section; ektosexine and nexine approximately equal in thickness, and each is approximately twice as thick as the endosexine. Coarsely reticulate in the intercolpium. Lumina polygonal to elongate-polygonal; maximum dimension of lumina $1.5-2.5 \mu \mathrm{m}$, typically $2 \mu \mathrm{m}$; diameter of brochi typically $3 \mu \mathrm{m}$; muri mainly 1-1.5 $\mu \mathrm{m}$ wide, simplibaculate to duplibaculate; lumina typically smaller near colpi. Colpi deep, mainly 2.5-7 $\mu \mathrm{m}$ wide in polar view and 14-30 $\mu \mathrm{m}$ long in equatorial view, boat-shaped; margines distinct to indistinct, commonly smooth, $0.5-2 \mu \mathrm{m}$ wide at the ora, generally narrowing toward the polar ends of the colpi; floor of colpus smooth when preserved. Ora $3-8 \mu \mathrm{m}$ in diameter, typically slightly larger than width of colpus; endannuli $0.5-1.5 \mu \mathrm{m}$ wide, generally narrow and rather indistinct.

Remarks. - The brochi in this species are midway in size between those of Lanagiopollis eocaenica (Krutzsch 1969) n. comb. and Rhoipites capax n. sp. The margines and to some extent the size of the brochi are similar to those of $L$. lihoka (Srivastava 1972) n. comb., but the exine is thicker in L. hadrodictya (Gr.: "hadros," thick, stout; "diktyon," net). Compared with Rhoipites capax, in Lanagiopollis hadrodictya the shape is typically more spheroidal, the margines are typically smoother, and the costae colpi are less distinct.

Distribution.-Known from the base of the Tallahatta Formation to the lower part of the Lisbon Formation. Whether the rare specimens that range as high as the Jacksonian Stage (Frederiksen, 1980c) are reworked or not remains to be determined.

Lanagiopollis sp. 1 (OTU 301)

Plate 12, figures 1-3

Remarks. - This species is similar to Lanagiopollis cribellata (Srivastava 1972) n. comb. (pl. 11, fig. 17) except that its exine is thicker, more than $2 \mu \mathrm{m}$ thick. The brochi are 1-1.5 $\mu \mathrm{m}$ in diameter; the design is reticulate to nearly foveolate. The design in this species is rather similar to that of the Lanagiopollis crassa type (Pelliceria), but Lanagiopollis sp. 1 has thick colpi margines and flat, smooth colpus floors like $L$. cribellata.

Distribution.-Middle of the Tallahatta Formation nearly to the top of the Lisbon Formation.

Lanagiopolks sp. 2 (OTU 303)

Plate 12, figures 4-8

Description.-Size 55-58 $\mu \mathrm{m}$ (two specimens). Oblate; outline rounded hexagonal. Exine in the intercolpium: in the specimen of plate 12 , figures $4-6,2 \mu \mathrm{m}$, sexine:nexine ca. $1: 1$; in the specimen of plate 12 , figures $7,8,3.8 \mu \mathrm{m}$, ektosexine:endosexine:nexine 0.8:0.8:2.2. Lumina typically elongate but not distinctly radially oriented; typical sizes of lumina 0.7 $1 \times 1.5 \mu \mathrm{m}$. Muri 1-2 $\mu \mathrm{m}$ wide, dupli- to polybaculate; design foveolate or nearly so. Floors of colpi smooth; colpi margines smooth, 1.5-2 $\mu \mathrm{m}$ wide, apparently thickened but flat. Ora 5-7 $\mu \mathrm{m}$ in diameter; in optical section, the entire exine of the annulus is homogeneous, columellae not visible there, 4-4.5 $\mu \mathrm{m}$ thick.

Remarks. - This species is characterized by its more or less foveolate design and elongate lumina. The wedge shape of the (end?)annulus in optical section is typical of pollen of Alangiaceae (Reitsma, 1970). The most similar previously described species is Alangiopollis simplex Nagy 1969, which has narrower muri and more radially directed lumina.

Distribution. - The two specimens known are from the Bashi Formation of eastern Alabama.

Genus BOMBACACIDITES Couper 1960

Bombacacidites cf. B. nanobrochatus Frederiksen 1983 (OTU 307)

Plate 15, figures $13-15,18-20$

Remarks.-This species is microreticulate like $B$. nanobrochatus, and the apertures are bombacaceous 
rather than tilioid, but the corners of the grain are more broadly rounded than in $B$. nanobrochatus. On the other hand, the corners are slightly more triangular than in Intratriporopollenites pseudinstructus Mai 1961, and the apertures lack the well-developed postvestibulum of $I$. pseudinstructus .

Distribution.-Lower part of the Bashi-Hatchetigbee interval to the upper part of the Lisbon Formation.

\section{Bombacacidites aff. B. reticulatus Krutzsch 1961 (OTU 315)} Plate 15, figures 16,17

Remarks.-This OTU includes pollen grains that are slightly more triangular in outline than the protologue specimens of $B$. reticulatus Krutzsch 1961 and its homonym (as well as subjective synonym) B. reticulatus (Groot \& Groot 1962) Srivastava 1972. I have the impression that true Bombacacidites reticulatus is more or less confined to the Paleocene, although a nearly circular specimen of this species was found in the Nanjemoy Formation (lower Eocene) of Virginia (Frederiksen, 1979, pl. 4, fig. 2). Krutzsch (1970b, pl. 4, figs. 7-9) included in $B$. reticulatus some specimens that have nearly straight sides; I exclude such morphotypes from this species and even from Bombacacidites aff. $B$. reticulatus.

Distribution.-Lower Sabinian Stage (upper Paleocene) to the middle part of the Tallahatta Formation.

\section{Bombacacidites sp. 1 (OTU 317)}

\section{Plate 15, figures 6-10}

Bombacacidites cf. B. nacimientoensis (Anderson 1960) Elsik 1968. Elsik, 1974a, pl. 2, figs. 68, 69.

Remarks.-This species is characterized by its medium size (22-28 $\mu \mathrm{m}$; six specimens), straight to slightly convex sides, and brochi that are $1 \mu \mathrm{m}$ or slightly smaller at the poles and are considerably smaller at the corners. In Bombacacidites hungaricus Kedves 1974, the brochi at the poles are ca. 0.8-2 $\mu \mathrm{m}$ in diameter and are ca. half that size at the corners. In $B$. nacimientoensis (Anderson 1960) Elsik 1968 (pl. 15, figs. 11,12 of this paper), the brochi at the poles are $1.5 \mu \mathrm{m}$ or larger in diameter (see Frederiksen, 1983), but the brochi at the corners are much smaller than those at the poles. Thus, Bombacacidites sp. 1 has a very fine reticulum at the corners like $B$. nacimientoensis, but the size of brochi at the poles is more like that of $B$. hungaricus .

Distribution.-Bashi-Hatchetigbee interval, possibly ranging as high as the middle part of the Tallahatta Formation.

Bombacacidites sp. 2 (OTU 319)

Plate 14, figures 14-18

Description.-Size 16-20 $\mu \mathrm{m}$ (two specimens). Oblate, outline triangular, sides slightly convex to slightly concave. Exine $1 \mu \mathrm{m}$ thick at the apertures, thinning slightly toward the corners. Brochi ca. $1 \mu \mathrm{m}$ in diameter at the poles and ca. $0.5 \mu \mathrm{m}$ in diameter at the corners. Colpi $1.5 \mu \mathrm{m}$ deep, bordered by exinal thickenings; ora not observed.

Remarks. - This species is characterized by its small size and nearly straight sides. Bombacacidites kettigensis minimus Krutzsch 1970 has more narrowly rounded corners, and the colpi lack significant thickenings. Bombacacidites tilioides Krutzsch 1970 has more narrowly rounded corners and is more finely reticulate.

Distribution.-Bashi-Hatchetigbee interval to the lower part of the Lisbon Formation.

\section{Genus INTRATRIPOROPOLLENITES Pflug \& Thomson} in Thomson \& Pflug 1953

\section{Intratriporopollenites pseudinstructus group (OTU 323)} Plate 15, figures 21, 22

Remarks.-This group includes Intratriporopollenites pseudinstructus Mai 1961 and I. insculptus Mai 1961. Pollen grains of these two species are of about the same size, and the main difference between them seems to be that in I. pseudinstructus the sexine overhangs the apertures whereas in I. insculptus it does not. In practice this is a difficult distinction to make. $I$. insculptus was stated by Mai (1961) to have duplibaculate muri, but this feature is not visible in the enlarged photomicrographs of the design pattern in this species (Mai, 1961, pl. 11, figs. 12-14). The muri of I. pseudinstructus were not described by Mai, and the nature of the muri in this species is also not visible in the photomicrographs of the design pattern (Mai, 1961, pl. 10, figs. 28-30).

Distribution. - Lower Sabinian (upper Paleocene) to the top of the Tallahatta Formation.

\section{Intratriporopollenites? sp. 1 (OTU 327) Plate 16, figures 1-3}

Bombacacaeae, Sterculiaceae or Tiliaceae? Elsik and Dilcher, 1974, pl. 29, figs. 91-93.

Remarks.-Pollen grains of this species are small (17-20 $\mu \mathrm{m}$; five specimens, including those of Elsik and Dilcher, 1974), have a fine reticulum $(1 \mu \mathrm{m}$ or less in diameter at the poles, not greatly smaller at the equator), and appear to lack a postvestibulum. The species is slightly smaller and has less tilioid apertures than Intratriporopollenites ceciliensis Krutzsch 1961. It is more finely reticulate than $I$. stavensis Frederiksen 1980 and more coarsely reticulate than $I$. minimus Mai 1961.

Distribution. - Tallahatta Formation of the eastern Gulf Coast; probable upper Claibornian strata of Tennessee (Elsik and Dilcher, 1974). 
Genus FRIEDRICHIPOLLIS Krutzsch 1970

Friedrichipollis sp. 1 (OTU 331)

Plate 16, figure 5

Description. - Size 26-30 $\mu \mathrm{m}$ (three specimens). Outline round; apertures tilioid. Outer sexine has a coarse reticulum with brochi $1.5-2.5 \mu \mathrm{m}$ in diameter and narrow muri; inner sexine design is punctate or microreticulate.

Remarks. - This species is characterized by its rather small size (for the genus), round shape, and tilioid apertures. tion.

Distribution. - Upper half of the Tallahatta Forma-

The locations of specimens shown in plates 1-16 are given in table 6 .

TABLE 6.-Locations of illustrated specimens

[Stratigraphic and geographic data on the samples are given in the plate explanations, in the "Sample Register," and in the text. All illustrated specimens are from the Eocene of the eastern Gulf Coast except plate 11, figure 17, which is from the upper Paleocene of Alabama]

\begin{tabular}{|c|c|c|c|}
\hline Plate & Figure & Slide & Coordinates \\
\hline \multirow[t]{14}{*}{$1 \ldots \ldots$} & $-1,2$ & R3236(2) & $45.9 \times 96.7$ \\
\hline & 3,4 & R3236(2) & $46.3 \times 102.5$ \\
\hline & 5 & R3236(1) & $41.9 \times 100.9$ \\
\hline & 6,7 & R2182B(2) & $45.9 \times 104.1$ \\
\hline & 8 & R3236(1) & $54.7 \times 100.4$ \\
\hline & 9 & $\mathrm{R} 2085 \mathrm{~F}(1)$ & $40.8 \times 100.8$ \\
\hline & 10,11 & UCR $8084(1)$ & $57.4 \times 99.7$ \\
\hline & 12 & UCR $8080(2)$ & $56.3 \times 99.6$ \\
\hline & 13,14 & UCR 8077(2) & $60.0 \times 107.3$ \\
\hline & 15,16 & $\mathrm{AC} 360^{\prime}(1)$ & $50.7 \times 110.3$ \\
\hline & 17 & UCR $8080(2)$ & $50.4 \times 102.0$ \\
\hline & 18,19 & UCR $8099(2)$ & $60.5 \times 103.5$ \\
\hline & 20 & UCR $8080(2)$ & $55.7 \times 102.4$ \\
\hline & 21,22 & UCR $8081(2)$ & $54.5 \times 103.8$ \\
\hline \multirow[t]{21}{*}{$2 \ldots$} & $-\quad 1$ & UCR $8081(2)$ & $50.8 \times 103.0$ \\
\hline & 2 & R1507B(2) & $54.8 \times 103.4$ \\
\hline & 3 & R3236(2) & $54.7 \times 99.3$ \\
\hline & 4 & $\mathrm{AC} 429^{\prime} 8^{\prime \prime}(1)$ & $45.9 \times 106.3$ \\
\hline & 5 & UCR $8087(1)$ & $66.0 \times 100.7$ \\
\hline & 6,7 & AC $396^{\prime}(1)$ & $43.7 \times 107.9$ \\
\hline & 8 & UCR $8097(2)$ & $37.1 \times 110.6$ \\
\hline & 9 & UCR 8095(2) & $49.7 \times 96.1$ \\
\hline & 10 & $\mathrm{AC} 555^{\prime}(1)$ & $47.5 \times 109.6$ \\
\hline & 11 & R2032(2) & $44.2 \times 102.5$ \\
\hline & 12 & R2663D(1) & $40.0 \times 102.6$ \\
\hline & 13 & R2274(1) & $49.1 \times 108.6$ \\
\hline & 14 & $\mathrm{AC} 485^{\prime} 6^{\prime \prime}(1)$ & $41.2 \times 111.2$ \\
\hline & 15,16 & UCR $8092(2)$ & $46.6 \times 101.2$ \\
\hline & 17 & R1138A(3) & $52.6 \times 96.4$ \\
\hline & 18 & $\mathrm{AC} 360^{\prime}(1)$ & $43.9 \times 99.7$ \\
\hline & 19 & $\mathrm{R} 2182 \mathrm{~B}(2)$ & $45.5 \times 99.5$ \\
\hline & 20 & R2274(1) & $50.7 \times 99.5$ \\
\hline & 21 & $\mathrm{R} 2085 \mathrm{~F}(1)$ & $43.3 \times 97.0$ \\
\hline & 22 & $\mathrm{R} 1507 \mathrm{~B}(2)$ & $47.2 \times 94.2$ \\
\hline & 23 & UCR $8069(2)$ & $50.1 \times 105.6$ \\
\hline
\end{tabular}

\begin{tabular}{|c|c|c|c|}
\hline Plate & Figure & Slide & Coordinates \\
\hline & 24 & $\mathrm{AC} 485^{\prime} 6^{\prime \prime}(1)$ & $45.6 \times 109.1$ \\
\hline & 25 & $\mathrm{R} 2085 \mathrm{~F}(1)$ & $46.5 \times 95.4$ \\
\hline & 26 & $\mathrm{AC} 360^{\prime}(\mathbf{1})$ & $50.5 \times 101.1$ \\
\hline & 27 & UCR 8076(1) & $49.2 \times 112.0$ \\
\hline \multirow[t]{17}{*}{ 3-- } & 1,2 & R3236(2) & $46.6 \times 99.3$ \\
\hline & 3 & R3236(2) & $57.8 \times 105.4$ \\
\hline & 4 & R3236(2) & $59.4 \times 108.1$ \\
\hline & 5 & $\mathrm{R} 2085 \mathrm{~F}(1)$ & $43.6 \times 97.9$ \\
\hline & 6 & $\mathrm{R} 2085 \mathrm{~F}(1)$ & $40.9 \times 106.8$ \\
\hline & 7,8 & UCR 8092(2) & $47.2 \times 106.8$ \\
\hline & 9,10 & UCR 8092(2) & $64.7 \times 104.7$ \\
\hline & 11 & $\mathrm{AC} 429^{\prime} 8^{\prime \prime}(1)$ & $45.6 \times 95.3$ \\
\hline & 12,13 & UCR $8080(2)$ & $51.7 \times 106.0$ \\
\hline & 14 & R2082M(1) & $51.1 \times 107.4$ \\
\hline & 15 & $\mathrm{R} 2082 \mathrm{~T}(2)$ & $53.0 \times 103.2$ \\
\hline & 16 & R1507B(2) & $49.8 \times 110.1$ \\
\hline & 17,18 & $\mathrm{AC} 340^{\prime}(1)$ & $43.8 \times 99.1$ \\
\hline & 19,20 & R2082M(1) & $46.9 \times 105.5$ \\
\hline & 21,22 & $\mathrm{R} 1507 \mathrm{~B}(2)$ & $55.4 \times 100.8$ \\
\hline & $23-25$ & UCR 8069(2) & $54.1 \times 95.7$ \\
\hline & 26 & $\mathrm{AC} 485^{\prime} 6^{\prime \prime}(1)$ & $50.4 \times 104.9$ \\
\hline \multicolumn{2}{|c|}{$4 \ldots 1,2$} & $\mathrm{AC} 360^{\prime}(1)$ & $52.6 \times 102.4$ \\
\hline & 3 & $\mathrm{R} 1507 \mathrm{~A}(2)$ & $58.2 \times 98.4$ \\
\hline & 4 & R2034B(1) & $51.4 \times 103.5$ \\
\hline & 5,6 & $\mathrm{AC} 429^{\prime} 8^{\prime \prime}(1)$ & $50.9 \times 106.3$ \\
\hline & $7-9$ & UCR 8093(2) & $63.1 \times 109.3$ \\
\hline & 10,11 & R2085F(1) & $40.9 \times 110.6$ \\
\hline & 12,13 & R2355A(1) & $42.0 \times 96.7$ \\
\hline & 14,15 & R2034B(1) & $56.6 \times 100.0$ \\
\hline & 16 & AC 582'(1) & $54.0 \times 103.7$ \\
\hline & $17-19$ & AC $396^{\prime}(1)$ & $55.5 \times 106.6$ \\
\hline & 20,21 & $\mathrm{AC} 485^{\prime} 6^{\prime \prime}(1)$ & $50.0 \times 100.2$ \\
\hline & 22,23 & UCR $8100(1)$ & $59.6 \times 112.2$ \\
\hline & 24,25 & UCR $8100(1)$ & $53.8 \times 101.8$ \\
\hline \multicolumn{2}{|c|}{$5 \ldots \ldots \ldots 1,2$} & UCR $8100(1)$ & $48.2 \times 103.3$ \\
\hline & 3,4 & R2031(2) & $47.0 \times 104.4$ \\
\hline & 5 & $\mathrm{R} 1507 \mathrm{~B}(2)$ & $51.7 \times 100.7$ \\
\hline & $6-8$ & UCR $8084(1)$ & $53.3 \times 98.8$ \\
\hline & 9 & $\mathrm{AC} 485^{\prime} 6^{\prime \prime}(1)$ & $40.5 \times 97.7$ \\
\hline & 10 & AC $486^{\prime} 6^{\prime \prime}(1)$ & $47.7 \times 108.7$ \\
\hline & $11-13$ & $\mathrm{AC} 485^{\prime} 6^{\prime \prime}(1)$ & $51.2 \times 101.8$ \\
\hline & 14 & $\mathrm{AC} 485^{\prime} 6^{\prime \prime}(1)$ & $44.3 \times 109.3$ \\
\hline & 15,16 & UCR $8069(2)$ & $57.3 \times 107.5$ \\
\hline & $17-19$ & UCR $8097(2)$ & $47.5 \times 95.4$ \\
\hline & 20,21 & $\mathrm{R} 2082 \mathrm{M}(1)$ & $43.7 \times 103.0$ \\
\hline & 22,23 & R2085F(1) & $43.5 \times 96.2$ \\
\hline \multicolumn{2}{|c|}{$6 \ldots \ldots \ldots 1,2$} & UCR 8095(2) & $47.1 \times 99.3$ \\
\hline & 3 & UCR $8069(2)$ & $51.9 \times 94.0$ \\
\hline & 4,5 & UCR 8068(1) & $47.5 \times 94.7$ \\
\hline & 6,7 & $\mathrm{R} 1507 \mathrm{~B}(2)$ & $49.4 \times 99.0$ \\
\hline & 8,9 & R3236(2) & $50.4 \times 108.8$ \\
\hline & 10,11 & R3236(2) & $60.0 \times 110.3$ \\
\hline & 12,13 & R2353(1) & $38.2 \times 98.5$ \\
\hline & 14,15 & R2085F(1) & $51.8 \times 94.0$ \\
\hline & 16,17 & $\mathrm{AC} 360^{\prime}(1)$ & $39.7 \times 106.7$ \\
\hline & 18,19 & R3236(1) & $55.0 \times 102.5$ \\
\hline & -1 & R2082T(2) & $46.9 \times 99.6$ \\
\hline & 2,3 & UCR 8099(2) & $63.6 \times 105.0$ \\
\hline & 4,5 & UCR $8099(2)$ & $56.3 \times 95.5$ \\
\hline & 6,7 & R1155(3) & $55.1 \times 106.1$ \\
\hline & $8-10$ & R1155(3) & $51.9 \times 96.0$ \\
\hline & 11,12 & $\mathrm{AC} 429^{\prime} 8^{\prime \prime}(1)$ & $50.8 \times 105.1$ \\
\hline
\end{tabular}


TABLE 6.-Locations of illustrated specimens-Continued

\begin{tabular}{|c|c|c|c|}
\hline Plate & Figure & Slide & Coordinates \\
\hline & 13,14 & AC $342^{\prime}(1)$ & $48.1 \times 98.4$ \\
\hline & 15 & $\mathrm{AC} 429^{\prime} 8^{\prime \prime}$ & $49.8 \times 101.6$ \\
\hline & 16 & UCR $8100(1)$ & $48.8 \times 100.2$ \\
\hline & 17,18 & UCR $8087(1)$ & $66.2 \times 100.3$ \\
\hline & 19,20 & UCR 8095(2) & $53.5 \times 100.0$ \\
\hline \multirow[t]{18}{*}{$8-$} & 1,2 & $\mathrm{R} 2082 \mathrm{M}(1)$ & $46.3 \times 104.6$ \\
\hline & 3 & UCR $8080(2)$ & $62.2 \times 103.1$ \\
\hline & 4 & $\mathrm{AC} 429^{\prime} 8^{\prime \prime}(1)$ & $54.8 \times 100.1$ \\
\hline & 5 & $\mathrm{R} 2355 \mathrm{~A}(1)$ & $39.3 \times 94.5$ \\
\hline & 6,7 & R1155(3) & $34.3 \times 106.3$ \\
\hline & 8 & $\mathrm{AC} 256^{\prime}(1)$ & $32.3 \times 95.3$ \\
\hline & 9 & $\mathrm{R} 2031(2)$ & $43.5 \times 109.9$ \\
\hline & 10,11 & $\mathrm{R} 1155(3)$ & $50.3 \times 110.5$ \\
\hline & 12 & R1155(3) & $47.0 \times 99.3$ \\
\hline & 13,14 & $\mathrm{R} 1507 \mathrm{~B}(2)$ & $56.4 \times 97.4$ \\
\hline & 15 & R1155(3) & $50.3 \times 110.5$ \\
\hline & 16 & R1155(3) & $50.4 \times 96.1$ \\
\hline & 17,18 & UCR 8084(1) & $50.8 \times 98.4$ \\
\hline & 19,20 & UCR 8095(1) & $53.5 \times 109.1$ \\
\hline & 21,22 & UCR $8095(2)$ & $48.2 \times 99.0$ \\
\hline & 23,24 & $\mathrm{AC} 429^{\prime} 8^{\prime \prime}(1)$ & $53.5 \times 109.5$ \\
\hline & 25,26 & $\mathrm{R} 2085 \mathrm{~F}(1)$ & $55.0 \times 102.7$ \\
\hline & 27,28 & R2032(1) & $42.8 \times 104.8$ \\
\hline \multirow[t]{14}{*}{$9-$} & 1,2 & R2353(1) & $41.6 \times 101.7$ \\
\hline & 3,4 & $\mathrm{R} 2082 \mathrm{~T}(2)$ & $53.2 \times 102.3$ \\
\hline & 5 & UCR 8095(2) & $50.3 \times 96.1$ \\
\hline & 6 & R2031(2) & $52.9 \times 92.4$ \\
\hline & 7 & $\mathrm{AC} 582^{\prime}(1)$ & $55.5 \times 107.6$ \\
\hline & 8 & UCR $8077(2)$ & $61.5 \times 110.3$ \\
\hline & 9,10 & $\mathrm{R} 1507 \mathrm{~B}(2)$ & $45.7 \times 95.1$ \\
\hline & 11 & UCR $8077(2)$ & $56.2 \times 111.6$ \\
\hline & 12 & $\mathrm{R} 1155(3)$ & $51.7 \times 108.6$ \\
\hline & $13-15$ & AC $396^{\prime}(1)$ & $53.7 \times 103.1$ \\
\hline & 16,17 & UCR $8087(1)$ & $59.5 \times 107.0$ \\
\hline & 18,19 & $\mathrm{AC} 396^{\prime}(1)$ & $54.8 \times 108.0$ \\
\hline & 20,21 & $\mathrm{R} 2082 \mathrm{M}(1)$ & $51.4 \times 98.3$ \\
\hline & 22,23 & $\mathrm{AC} 340^{\prime}(1)$ & $38.5 \times 99.6$ \\
\hline \multirow[t]{13}{*}{10} & $1-3$ & $\mathrm{AC} 342^{\prime}(1)$ & $62.5 \times 99.8$ \\
\hline & 4 & R2082M(1) & $51.3 \times 106.3$ \\
\hline & 5,6 & UCR 8069(2) & $59.3 \times 101.9$ \\
\hline & 7,8 & UCR $8069(2)$ & $51.2 \times 103.3$ \\
\hline & 9,10 & UCR 8095(1) & $57.6 \times 101.9$ \\
\hline & $11-13$ & $\mathrm{AC} 342^{\prime}(1)$ & $61.8 \times 98.7$ \\
\hline & 14 & UCR 8084(1) & $55.6 \times 101.1$ \\
\hline & 15,16 & UCR $8084(1)$ & $52.7 \times 99.8$ \\
\hline & 17,18 & R2082K(1) & $39.3 \times 110.5$ \\
\hline & $19-21$ & $\mathrm{R} 1507 \mathrm{~B}(2)$ & $48.2 \times 97.2$ \\
\hline & 22 & $\mathrm{R} 1507 \mathrm{~B}(2)$ & $55.4 \times 109.3$ \\
\hline & 23 & $\mathrm{R} 1507 \mathrm{~A}(2)$ & $59.2 \times 107.3$ \\
\hline & 24 & $\mathrm{R} 2085 \mathrm{~F}(1)$ & $44.1 \times 100.0$ \\
\hline \multirow[t]{8}{*}{$11 \ldots$} & 1,2 & R2353(1) & $34.4 \times 102.1$ \\
\hline & 3,4 & $\mathrm{R} 2353(1)$ & $43.5 \times 97.3$ \\
\hline & 5,6 & UCR $8080(2)$ & $49.1 \times 94.2$ \\
\hline & $7-9$ & UCR 8093(2) & $45.4 \times 108.0$ \\
\hline & 10,11 & $\mathrm{R} 1507 \mathrm{~B}(2)$ & $37.3 \times 94.1$ \\
\hline & 12,13 & UCR $8069(2)$ & $51.1 \times 107.5$ \\
\hline & 14 & UCR $8077(2)$ & $57.7 \times 102.7$ \\
\hline & 15,16 & UCR $8077(2)$ & $51.3 \times 95.7$ \\
\hline & 17 & $\mathrm{R} 2587 \mathrm{~B}(1)$ & $44.6 \times 104.8$ \\
\hline \multirow[t]{3}{*}{$12 \cdots$} & $1-3$ & $\mathrm{AC} 256^{\prime}(1)$ & $32.6 \times 110.0$ \\
\hline & $4-6$ & $\mathrm{R} 3236(2)$ & $43.3 \times 97.9$ \\
\hline & 7,8 & $\mathrm{R} 3236(1)$ & $58.4 \times 95.8$ \\
\hline
\end{tabular}

TABLE 6.-Locations of illustrated specimens-Continued

\begin{tabular}{|c|c|c|c|}
\hline Plate & Figure & Slide & Coordinates \\
\hline & 9,10 & $\mathrm{AC} 485^{\prime} 6^{\prime \prime}(1)$ & $43.6 \times 104.5$ \\
\hline \multirow{8}{*}{$13-}$. & 1,2 & UCR 8077(2) & $53.9 \times 108.4$ \\
\hline & 3 & R1507B(2) & $56.7 \times 102.0$ \\
\hline & $4-6$ & AC $396^{\prime}(1)$ & $52.8 \times 100.0$ \\
\hline & 7,8 & $\mathrm{R} 1507 \mathrm{~B}(2)$ & $52.8 \times 93.8$ \\
\hline & 9 & UCR 8077(2) & $56.5 \times 101.0$ \\
\hline & 10,11 & $\mathrm{R} 2080 \mathrm{~A}(3)$ & $41.0 \times 93.0$ \\
\hline & 12 & UCR $8084(1)$ & $57.3 \times 99.6$ \\
\hline & 13,14 & UCR $8080(2)$ & $55.7 \times 97.2$ \\
\hline \multirow[t]{8}{*}{14} & 1,2 & UCR 8095(2) & $47.0 \times 102.5$ \\
\hline & $3-5$ & $\mathrm{AC} 429^{\prime} 8^{\prime \prime}(1)$ & $49.6 \times 101.2$ \\
\hline & 6,7 & $\mathrm{AC} 485^{\prime} 6^{\prime \prime}(1)$ & $49.1 \times 95.6$ \\
\hline & $8-10$ & UCR $8077(2)$ & $60.6 \times 105.8$ \\
\hline & 11 & $\mathrm{AC} 429^{\prime} 8^{\prime \prime}(1)$ & $45.3 \times 93.2$ \\
\hline & 12,13 & UCR 8092(2) & $58.1 \times 106.0$ \\
\hline & 14,15 & R3236(2) & $55.4 \times 111.2$ \\
\hline & $16-18$ & $\mathrm{AC} 360^{\prime}(1)$ & $58.4 \times 102.2$ \\
\hline \multirow[t]{18}{*}{15} & 1,2 & R2085F(1) & $41.5 \times 93.9$ \\
\hline & 3,4 & R2085F(1) & $44.5 \times 94.7$ \\
\hline & 5 & $\mathrm{R} 2085 \mathrm{~F}(1)$ & $43.7 \times 97.0$ \\
\hline & 6 & $\mathrm{R} 2085 \mathrm{~F}(1)$ & $44.3 \times 97.0$ \\
\hline & 7,8 & $\mathrm{R} 2085 \mathrm{~F}$ (1) & $43.7 \times 99.0$ \\
\hline & 9,10 & R2032(2) & $43.3 \times 101.7$ \\
\hline & 11,12 & R2085F(1) & $43.6 \times 105.9$ \\
\hline & 13 & UCR 8069(2) & $54.2 \times 106.5$ \\
\hline & 14 & R1507B(2) & $44.4 \times 108.0$ \\
\hline & 15 & UCR 8069(2) & $55.9 \times 107.5$ \\
\hline & 16 & $\mathrm{R} 2034 \mathrm{~B}(1)$ & $59.7 \times 109.4$ \\
\hline & 17 & R2085F(1) & $40.8 \times 96.4$ \\
\hline & 18 & $\mathrm{R} 2274(1)$ & $45.8 \times 111.6$ \\
\hline & 19 & UCR 8076(1) & $52.5 \times 100.2$ \\
\hline & 20 & $\mathrm{AC} 485^{\prime} 6^{\prime \prime}(1)$ & $41.1 \times 99.2$ \\
\hline & 21,22 & $\mathrm{R} 2663 \mathrm{C}(2)$ & $41.0 \times 100.3$ \\
\hline & 23 & UCR 8069(2) & $57.5 \times 98.3$ \\
\hline & 24,25 & $\mathrm{R} 2353(1)$ & $38.1 \times 107.0$ \\
\hline \multirow[t]{11}{*}{16} & 1 & $\mathrm{R} 1507 \mathrm{~B}(2)$ & $38.7 \times 98.0$ \\
\hline & 2 & $\mathrm{R} 1507 \mathrm{~B}(2)$ & $50.2 \times 106.1$ \\
\hline & 3 & R1507B(2) & $52.4 \times 103.4$ \\
\hline & 4 & R1507B(2) & $44.9 \times 102.2$ \\
\hline & 5 & $\mathrm{R} 1507 \mathrm{~B}(2)$ & $56.4 \times 100.2$ \\
\hline & 6,7 & UCR 8099(2) & $35.5 \times 102.5$ \\
\hline & 8,9 & R2082M(1) & $46.4 \times 100.6$ \\
\hline & 10,11 & UCR $8080(2)$ & $61.1 \times 109.0$ \\
\hline & 12,13 & $\mathrm{R} 2082 \mathrm{M}(1)$ & $48.3 \times 107.1$ \\
\hline & 14 & $\mathrm{R} 2082 \mathrm{M}(1)$ & $47.1 \times 106.4$ \\
\hline & 15,16 & UCR 8095(2) & $59.7 \times 104.8$ \\
\hline
\end{tabular}

\section{REFERENCES CITED}

Axelrod, D.I., 1966, A method for determining the altitudes of Tertiary floras: Palaeobotanist, v. 14, p. 144-171.

Bandy, O.L., 1949, Eocene and Oligocene foraminifera from Little Stave Creek, Clarke County, Alabama: Bulletins of American Paleontology, v. 32, no. 131,210 p.

Berggren, W.A., Kent, D.V., and Flynn, J.J., 1982, Cenozoic geochronology, 1982 [abs.]: Geological Society of America, Abstracts with Programs, v. 14, p. 442.

Berggren, W.A., Kent, D.V., Flynn, J.J., and Van Couvering, J.A., 1985, Cenozoic geochronology: Geological Society of America Bulletin, v. 96, p. 1407-1418. 
Berry, E.W., 1924, The middle and upper Eocene floras of southeastern North America: U.S. Geological Survey Professional Paper $92,206 \mathrm{p}$.

Bicker, A.R., Jr., 1965, Hinds County structural geology, in Moore, W.H., Bicker, A.R., Jr., McCutcheon, T.E., and Parks, W.S., Hinds County geology and mineral resources: Mississippi Geological, Economic and Topographical Survey Bulletin 105, p. 147-156.

Blow, W.H., 1969, Late middle Eocene to recent planktonic foraminiferal biostratigraphy, in Brönnimann, P., and Renz, H.H., eds., International Conference on Planktonic Microfossils, 1st, Geneva 1967, Proceedings, v. 1, p. 199-421.

1979, The Cainozoic Globigerinida: Leiden, Netherlands, E.J. Brill, v. 1-3, 1,413 p.

Bujak, J.P., Downie, Charles, Eaton, G.L., and Williams, G.L., 1980, Taxonomy of some Eocene dinoflagellate cyst species from southern England, in Bujak, J.P., Downie, Charles, Eaton, G.L., and Williams, G.L., Dinoflagellate cysts and acritarchs from the Eocene of southern England: The Palaeontological Association [London] Special Papers in Palaeontology, no. 24, p. 26-36.

Bybell, L.M., 1975, Middle Eocene calcareous nannofossils at Little Stave Creek, Alabama: Tulane Studies in Geology and Paleontology, v. 11, p. 177-252.

1980, Paleogene calcareous nannofossils, in Reinhardt, Juergen, and Gibson, T.G., Upper Cretaceous and lower Tertiary geology of the Chattahoochee River Valley, western Georgia and eastern Alabama, in Frey, R.W., ed., Excursions in southeastern geology, v. 2: Geological Society of America Annual Meeting, 93d, Atlanta 1980, Field Trip Guidebooks, p. 416-421.

1982, Late Eocene to early Oligocene calcareous nannofossils in Alabama and Mississippi: Gulf Coast Association of Geological Societies, Transactions, v. 32, p. 295-302.

Bybell, L.M., and Gibson, T.G., 1985, The Eocene Tallahatta Formation of Alabama and Georgia: Its lithostratigraphy, biostratigraphy, and bearing on the age of the Claibornian Stage: U.S. Geological Survey Bulletin 1615, $20 \mathrm{p}$.

Bybell, L.M., and Poore, R.Z., 1983, Reworked Hantkenina specimens at Little Stave Creek, Alabama: Gulf Coast Association of Geological Societies, Transactions, v. 33, p. 253-256.

Causey, L.V., and Newton, J.G., 1972, Geology of Clarke County, Alabama: Geological Survey of Alabama Map 95, 20 p. and map, scale $1: 125,000$.

Chateauneuf, Jean-Jacques, 1980, Palynostratigraphie et paléoclimatologie de l'Eocène Supérieur et de l'Oligocène du Bassin de Paris: Bureau de Recherches Géologiques et Minières, Mémoire $116,360 \mathrm{p}$.

Christopher, R.A., Prowell, D.C., Reinhardt, Juergen, and Markewich, H.W., 1980, The stratigraphic and structural significance of Paleocene pollen from Warm Springs, Georgia: Palynology, v. 4, p. 105-124.

Collinson, M.E., Fowler, Keith, and Boulter, M.C., 1981, Floristic changes indicate a cooling climate in the Eocene of southern England: Nature, v. 291, no. 5813, p. 315-317.

Costa, L.I., and Downie, Charles, 1976, The distribution of the dinoflagellate Wetzeliella in the Paleogene of north-western Europe: Palaeontology, v. 19, p. 591-614.

Cousminer, H.L., 1961, Palynology, paleofloras and paleoenvironments: Micropaleontology, v. 7, p. 365-368.

Curry, D., Adams, C.G., Boulter, M.C., Dilley, F.C., Eames, F.E., Funnell, B.M., and Wells, M.K., 1978, A correlation of Tertiary rocks in the British Isles: Geological Society of London Special Report $12,72 \mathrm{p}$.

DeVries, D.A., 1963, Jasper County mineral resources, in Jasper County mineral resources: Mississippi Geological, Economic and Topographical Survey Bulletin 95, p. 11-52.
Dilcher, D.L., 1973, A paleoclimatic interpretation of the Eocene floras of southeastern North America, in Graham, Alan, ed., Vegetation and vegetational history of northern Latin America: Amsterdam, Elsevier, p. 39-59.

Dockery, D.T., III, 1980, The invertebrate macropaleontology of the Clarke County, Mississippi, area: Mississippi Bureau of Geology Bulletin 122, $387 \mathrm{p}$.

1982, Lower Oligocene Bivalvia of the Vicksburg Group in Mississippi: Mississippi Bureau of Geology Bulletin 123, $261 \mathrm{p}$. 1984, Stratigraphy, in MacNeil, F.S., and Dockery, D.T., III, Lower Oligocene Gastropoda, Scaphopoda, and Cephalopoda of the Vicksburg Group in Mississippi: Mississippi Bureau of Geology Bulletin 124, p. 10-24.

Dockery, D.T., III, Copeland, C.W., Jr., and Huddlestun, P.F., 1984, Reply to a revision of the Hatchetigbee and Bashi Formations: Mississippi Geology, v. 4, no. 3, p. 11-15.

Dockery, D.T., III, and Siesser, W.G., 1984, Age of the upper Yazoo Formation in central Mississippi: Mississippi Geology, v. 5, p. 110.

Doktorowicz-Hrebnicka, Julia, 1960, Correlation of brown coal seams from the provinces of Poznan and Bydgoszcz: Instytut Geologiczny, Warszawa, Biuletyn 157, p. 223-243.

Dorf, Erling, 1960, Climatic changes of the past and present: American Scientist, v. 48, p. 341-364.

Edwards, L.E., 1977, Range charts as chronostratigraphic hypotheses, with applications to Tertiary dinoflagellates: Riverside, University of California, Riverside, unpublished Ph.D. dissertation, $188 \mathrm{p}$.

1979, Range charts and no-space graphs: Computers \& Geosciences, v. 4 , p. $247-255$.

1984, Insights on why graphic correlation (Shaw's method) works: Journal of Geology, v. 92, p. 583-597.

Elsik, W.C., 1968a, Palynology of a Paleocene Rockdale lignite, Milam County, Texas. II. Morphology and taxonomy (end): Pollen et Spores, v. 10, p. 599-664.

-1968 b, Palynology of the Wilcox Group, in Atlee, W.A., Elsik, W.C., Frazier, D.E., and Zingula, R.P., Field trip guidebook: Environments of deposition, Wilcox Group, Texas Gulf Coast: Houston Geological Society, p. 22-27.

1974a, Characteristic Eocene palynomorphs in the Gulf Coast, U.S.A.: Palaeontographica, Abt. B, v. 149, p. 90-111.

1974b, Nothofagus in North America: Pollen et Spores, v. 16, p. 285-299.

1978, Palynology of Gulf Coast lignites: The stratigraphic framework and depositional environments: Texas University Bureau of Economic Geology Report of Investigations 90, p. 2132.

Elsik, W.C., and Dilcher, D.L., 1974, Palynology and age of clays exposed in Lawrence clay pit, Henry County, Tennessee: Palaeontographica, Abt. B, v. 146, p. 65-87.

Fairchild, W.W., and Elsik, W.C., 1969, Characteristic palynomorphs of the Lower Tertiary in the Gulf Coast: Paleontographica, Abt. B, v. 128 , p. $81-89$.

Fisher, W.L., 1964, Sedimentary patterns in Eocene cyclic deposits, northern Gulf Coast region: Kansas Geological Survey Bulletin 169, p. 151-170.

Frederiksen, N.O., 1969, Stratigraphy and palynology of the Jackson Stage (upper Eocene) and adjacent strata of Mississippi and western Alabama: Madison, University of Wisconsin, unpublished dissertation, $355 \mathrm{p}$.

1973, New mid-Tertiary spores and pollen grains from Mississippi and Alabama: Tulane Studies in Geology and Paleontology, v. 10 , p. $65-86$

1978, Note on the conversion of microscope stage coordinates: Micropaleontology, v. 24, p. 222-223. 
1979, Paleogene sporomorph biostratigraphy, northeastern Virginia: Palynology, v. 3, p. 129-167.

1980a, Mid-Tertiary climate of southeastern United States: The sporomorph evidence: Journal of Paleontology, v. 54, p. 728739.

$1980 \mathrm{~b}$, Paleogene sporomorphs from South Carolina and quantitative correlations with the Gulf Coast: Palynology, v. 4, p. 125-179.

1980c, Sporomorphs from the Jackson Group (upper Eocene) and adjacent strata of Mississippi and western Alabama: U.S. Geological Survey Professional Paper 1084, 75 p.

1981, Middle Eocene to early Oligocene plant communities of the Gulf Coast, in Gray, Jane, Boucot, A.J., and Berry, W.B.N., eds., Communities of the past: Stroudsburg, Pa., Hutchinson Ross, p. 493-549.

1983, Angiosperm pollen and miscellanea, in Middle Eocene palynomorphs from San Diego, California: American Association of Stratigraphic Palynologists Contributions Series, no. 12, p. 32-109, 124-155.

-1985, Sporomorph zonation of the Eocene of southern California [abs.]: Geological Society of America, Abstracts with Programs, v. 17 , p. 355 .

Frederiksen, N.O., and Ames, H.T., 1979, Status of the pollen genus Pollenites: Taxon, v. 28, p. 557-561.

Frederiksen, N.O., Carr, D.R., Lowe, G.D., and Wosika, E.P., 1983, Introduction, spores, and gymnosperm pollen, in Middle Eocene palynomorphs from San Diego, California: American Association of Stratigraphic Palynologists Contributions Series, no. 12, p. 1-31, 110-123.

Frederiksen, N.O., and Christopher, R.A., 1978, Taxonomy and biostratigraphy of Late Cretaceous and Paleogene triatriate pollen from South Carolina: Palynology, v. 2, p. 113-145.

Frederiksen, N.O., Gibson, T.G., and Bybell, L.M., 1982, PaleoceneEocene boundary in the eastern Gulf Coast: Gulf Coast Association of Geological Societies, Transactions, v. 32, p. 289-294.

Frederiksen, N.O., Wiggins, V.D., Ferguson, I.K., Dransfield, John, and Ager, C.M., 1985, Distribution, paleoecology, paleoclimatology, and botanical affinity of the Eocene pollen genus Diporoconia n. gen.: Palynology, v. 9, p. 37-60.

Germeraad, J.H., Hopping, C.A., and Muller, Jan, 1968, Palynology of Tertiary sediments from tropical areas: Review of Palaeobotany and Palynology, v. 6, p. 189-348.

Gibson, T.G., 1980, Facies changes of lower Paleogene strata, in Reinhardt, Juergen, and Gibson, T.G., Upper Cretaceous and lower Tertiary geology of the Chattahoochee River Valley, western Georgia and eastern Alabama, in Frey, R.W., ed., Excursions in southeastern geology, v. 2: Geological Society of America Annual Meeting, 93d, Atlanta 1980, Field Trip Guidebooks, p. 402411.

-1982, Revision of the Hatchetigbee and Bashi Formations (lower Eocene) in the eastern Gulf Coastal Plain, in Stratigraphic notes, 1980-1982: U.S. Geological Survey Bulletin 1529-H, p. H33-H41.

Gibson, T.G., and Bybell, L.M., 1981, Facies changes in the Hatchetigbee Formation in Alabama-Georgia and the WilcoxClaiborne Group unconformity: Gulf Coast Association of Geological Societies, Transactions, v. 31, p. 301-306.

1984, Multiple depositional cycles in Bashi and Hatchetigbee Formations (lower Eocene), Alabama [abs.]: American Association of Petroleum Geologists Bulletin, v. 68, p. 480.

Gibson, T.G., Mancini, E.A., and Bybell, L.M., 1982, Paleocene to middle Eocene stratigraphy of Alabama: Gulf Coast Association of Geological Societies, Transactions, v. 32, p. 449-458.

Gilliland, W.A., 1980, Clarke County geology, in Clarke County geology and mineral resources: Mississippi Bureau of Geology Bulletin 121, p. 11-147.
Gladkova, A.N., 1965, Iskopaemye Myricaceae Zapadnoi Sibiri (Fossil Myricaceae from western Siberia): Trudy Vsesoyuznogo Neftyanogo Nauchno-Issledovatel'skogo Geologo-Razvedochnogo Instituta, no. 239, p. 142-190.

Graham, Alan, 1977, New records of Pelliceria (Theaceae/Pelliceriaceae) in the Tertiary of the Caribbean: Biotropica, v. 9, p. 4852.

Graham, Alan, and Jarzen, D.M., 1969, Studies in neotropical paleobotany. I. The Oligocene communities of Puerto Rico: Missouri Botanical Garden, Annals, v. 56, p. 308-357.

Groot, J.J., and Groot, C.R., 1962, Some plant microfossils from the Brightseat Formation (Paleocene) of Maryland: Palaeontographica, Abt. B, v. 111, p. 161-171.

Hammen, Thomas van der, and Wymstra, T.A., 1964, A palynological study on the Tertiary and Upper Cretaceous of British Guiana: Leidse Geologische Mededelingen [Netherlands], v. 30, p. 183-241.

Hardenbol, Jan, and Berggren, W.A., 1978, A new Paleogene numerical time scale, in Cohee, G.V., Glaessner, M.F., and Hedberg, H.D., eds., Contributions to the geologic time scale: American Association of Petroleum Geologists Studies in Geology, no. 6, p. 213-234.

Hazel, J.E., Bybell, Laurel, Christopher, R.A., Frederiksen, N.O., May, F.E., McLean, D.M., Poore, R.Z., Smith, C.C., Sohl, N.F., Valentine, P.C., and Witmer, R.J., 1977, Biostratigraphy of the deep corehole (Clubhouse Crossroads corehole 1) near Charleston, South Carolina: U.S. Geological Survey Professional Paper 1028-F, p. 71-89.

Hazel, J.E., Bybell, L.M., Edwards, L.E., Jones, G.D., and Ward, L.W., 1984, Age of the Comfort Member of the Castle Hayne Formation, North Carolina: Geological Society of America Bulletin, v. 95, p. 1040-1044.

Hazel, J.E., Edwards, L.E., and Bybell, L.M., 1984, Significant unconformities and the hiatuses represented by them in the Paleogene of the Atlantic and Gulf Coastal province, in Schlee, J.S., ed., Interregional unconformities and hydrocarbon accumulations: American Association of Petroleum Geologists Memoir 36, p. 59-66.

Hickey, L.J., 1977, Stratigraphy and paleobotany of the Golden Valley Formation (Early Tertiary) of western North Dakota: Geological Society of America Memoir 150, $181 \mathrm{p}$.

Hoffman, Antoni, and Kitchell, J.A., 1984, Evolution in a pelagic planktic system: A paleobiologic test of models of multispecies evolution: Paleobiology, v. 10, p. 9-33.

Hubbard, R.N.L.B., and Boulter, M.C., 1983, Reconstruction of Palaeogene climate from palynological evidence: Nature, v. 301, no. 5896 , p. $147-150$.

Huddlestun, P.F., Marsalis, W.E., and Pickering, S.M., Jr., 1974, Tertiary stratigraphy of the central Georgia coastal plain: Geological Society of America, Southeastern Section, Guidebook 12 , p. 2-1-2-13.

Jansonius, Jan, and Hills, L.V., 1976, Genera file of fossil spores: Calgary, Alberta, University of Calgary Department of Geology Special Publication, 3,287 cards.

Kedves, Miklos, 1974, Paleogene fossil sporomorphs of the Bakony Mountains, pt. II: Studia Biologica Hungarica, v. 13, 124 p. 1978, Paleogene fossil sporomorphs of the Bakony Mountains, pt. III: Studia Biologica Hungarica, v. 15, 166 p.

Keller, Gerta, 1985, Eocene and Oligocene stratigraphy and erosional unconformities in the Gulf of Mexico and Gulf Coast: Journal of Paleontology, v. 59, p. 882-903.

Knoll, A.H., 1984, Patterns of extinction in the fossil record of vascular plants, in Nitecki, M.H., ed., Extinctions: Chicago, University of Chicago Press, p. 21-68.

Knoll, A.H., Niklas, K.J., and Tiffney, B.H., 1979, Phanerozoic landplant diversity in North America: Science, v. 206, p. 1400-1402. 
Krutzsch, Wilfried, 1957, Sporen- und Pollengruppen aus der Oberkreide und dem Tertiär Mitteleuropas und ihre stratigraphische Verteilung: Zeitschrift für Angewandte Geologie, v. 3, p. 509-548.

1961, Beitrag zur Sporenpaläontologie der präoberoligozänen kontinentalen und marinen Tertiärablagerungen Brandenburgs: Berichte der Geologischen Gesellshaft in der Deutschen Demokratischen Republik, v. 5, p. 290-343.

1966, Die sporenstratigraphische Gliederung des älteren Tertiär im nördlichen Mitteleuropa (Paläozän-Mitteloligozän). Methodische Grundlagen und gegenwärtiger Stand der Untersuchungen. Abhandlungen des Zentralen Geologischen Instituts, v. 8 , p. $112-149$.

1968, Brosipollis und Labrapollis, zwei neue Pollengenera aus dem Tertiär Mitteleuropas: Review of Palaeobotany and Palynology, v. 6, p. 61-70.

1969, Ueber einige stratigraphisch wichtige neue Longaxoner-Pollen aus dem mitteleuropäischen Alttertiär: Geologie, v. 18 , p. 472-487.

-1970a, Atlas der mittel- und jungtertiären dispersen Sporenund Pollen- sowie der Mikroplanktonformen des nördlichen Mitteleuropas, VII: Jena, German Democratic Republic, VEB Gustav Fischer Verlag, $175 \mathrm{p}$.

1970b, Einige neue Pollenformen aus den Familien der Tiliaceen, Bombacaceen und Sterculiaceen aus dem mitteleuropäischen Alttertiär: Jahrbuch für Geologie, v. 3, p. 275-307.

1970c, Die stratigraphisch verwertbaren Sporen- und Pollenformen des mitteleuropäischen Alttertiärs: Jahrbuch für Geologie, v. 3, p. 309-379.

Krutzsch, Wilfried, and Vanhoorne, Rogier, 1977, Die Pollenflora von Epinois und Loksbergen in Belgien: Palaeontographica, Abt. B, v. 163 , p. 1-110.

Mai, D.H., 1961, Ueber eine fossile Tiliaceen-Blüte und tilioiden Pollen aus dem deutschen Tertiär: Geologie Beihefte, v. 32, p. 54-93.

Mancini, E.A., 1979, Eocene-Oligocene boundary in southwest Alabama: Gulf Coast Association of Geological Societies, Transactions, v. 29, p. 282-289.

Mancini, E.A., and Oliver, G.E., 1981, Planktic foraminifers from the Tuscahoma Sand (upper Paleocene) of southwest Alabama: Micropaleontology, v. 27, p. 204-225.

Marsalis, W.E., and Friddell, M.S., 1975, A guide to selected Upper Cretaceous and Lower Tertiary outcrops in the lower Chattahoochee River Valley of Georgia: Atlanta, Georgia Geological Society Field Trip Guidebook 15, 79 p.

Martini, Erlend, 1971, Standard Tertiary and Quaternary calcareous nannoplankton zonation, in Farinacci, Anna, ed., Planktonic Conference, 2d, Rome, 1970, Proceedings, v. 2, p. 739-785.

May, J.H., 1974, Wayne County geology and mineral resources: Mississippi Geological, Economic and Topographical Survey Bulletin $117,293 \mathrm{p}$

McCammon, R.B., 1970, On estimating the relative biostatigraphic value of fossils: Bulletin of the Geological Institutions of the University of Uppsala, new ser., v. 2, p. 49-57.

McKenna, M.C., 1975, Fossil mammals and early Eocene North Atlantic land continuity: Missouri Botanical Garden Annals, v. 62, p. 335-353.

1983, Cenozoic paleogeography of North Atlantic land bridges, in Bott, M.H.P., Saxov, Svend, Talwani, Manik, and Thiede, Jorn, eds., Structure and development of the Greenland-Scotland Ridge: New York, Plenum, p. 351-399.

Mildenhall, D.C., and Harris, W.F., 1971, Status of Haloragacidites (al. Triorites) harrisii (Couper) Harris comb. nov. and Haloragacidites trioratus Couper, 1953: New Zealand Journal of Botany, v. 9, p. 297-306.

Miller, F.X., 1977, The graphic correlation method in biostratigra- phy, in Kauffman, E.G., and Hazel, J.E., eds., Concepts and methods of biostratigraphy: Stroudsburg, Pa., Dowden, Hutchinson and Ross, p. 165-186.

Monroe, W.H., 1954, Geology of the Jackson area, Mississippi: U.S. Geological Survey Bulletin 986, 133 p.

Morley, R.J., 1982, Fossil pollen attributable to Alangium Lamarck (Alangiaceae) from the Tertiary of Malesia: Review of Palaeobotany and Palynology, v. 36, p. 65-94.

Muller, Jan, 1981, Fossil pollen records of extant angiosperms: Botanical Review, v. 47, p. 1-142.

Murray, G.E., 1961, Geology of the Atlantic and Gulf Coastal province of North America: New York, Harper \& Bros., 692 p.

Niklas, K.J., 1977, Theoretical evolutionary rates in plant groups and the fossil record: Brittonia, v. 29, p. 241-254.

1978, Coupled evolutionary rates and the fossil record: Brittonia, v. 30, p. 373-394.

Niklas, K.J., Tiffney, B.H., and Knoll, A.H., 1979, Apparent changes in the diversity of fossil plants, in Hecht, M.K., Steere, W.C., and Wallace, B., eds., Evolutionary biology: New York, Plenum, v. 12 , p. $1-89$.

1983, Patterns in vascular land plant diversification: Nature, v. 303 , p. $614-616$.

Potonié, Robert, 1931a, Zur Mikroskopie der Braunkohlen. Tertiäre Blütenstaubformen: Braunkohle, no. 16, p. 325-333. 1931b, Pollenformen aus tertiären Braunkohlen: Preussische Geologische Landesanstalt zu Berlin, Jahrbuch, v. 52, p. 1-7.

1934, Zur Mikrobotanik des eocänen Humodils des Geiseltals: Preussische Geologische Landesanstalt zu Berlin, Institut für Paläobotanik und Petrographie der Brennsteine, Arbeiten, v. 4, p. 25-117.

1960, Synopsis der Gattungen der.Sporae dispersae, III. Teil: Geologisches Jahrbuch, Beihefte, no. 39, 189 p.

Potter, F.W., Jr., 1976, Investigations of angiosperms from the Eocene of southeastern North America-Pollen assemblages from Miller pit, Henry County, Tennessee: Palaeontographica, Abt. B, v. 157, p. 44-96.

Reinhardt, Juergen, and Gibson, T.G., 1980, Field trip 20 road log, Upper Cretaceous-lower Tertiary, Chattahoochee River Valley, in Reinhardt, Juergen, and Gibson, T.G., Upper Cretaceous and lower Tertiary geology of the Chattahoochee River Valley, western Georgia and eastern Alabama, in Frey, R.W., ed., Excursions in southeastern geology, v. 2: Geological Society of America Annual Meeting, 93d, Atlanta 1980, Field Trip Guidebooks, p. 431463.

Reitsma, Tj., 1970, Pollen morphology of the Alangiaceae: Review of Palaeobotany and Palynology, v. 10, p. 249-332.

Rouse, G.E., and Srivastava, S.K., 1972, Palynological zonation of Cretaceous and Early Tertiary rocks of the Bonnet Plume Formation, northeastern Yukon, Canada: Canadian Journal of Earth Science, v. 9, p. 1163-1179.

Scott, J.C., 1972, Geology of Monroe County, Alabama: Alabama Geological Survey Map 101, 12 p., map.

Shaw, A.B., 1964, Time in stratigraphy: New York, McGraw-Hill, $365 \mathrm{p}$.

Siesser, W.G., 1983, Paleogene calcareous nannoplankton biostratigraphy, Mississippi, Alabama and Tennessee: Mississippi Bureau of Geology Bulletin 125, $61 \mathrm{p}$.

1984, Paleogene sea levels and climates, U.S.A. eastern Gulf Coastal Plain: Palaeogeography, Palaeoclimatology, Palaeoecology, v. 47 , p. 261-275.

Simpson, J.B., 1961, The Tertiary pollen-flora of Mull and Ardnamurchan: Royal Society of Edinburgh, Transactions, v. 64, p. 421-468:

Smith, R.H., and others, 1944, Little Stave Creek, Clarke County, Alabama, in Southeastern Geological Society Guidebook, 1st field trip, southwestern Alabama, 1944: 2 pls. 
Snyder, S.W., Müller, Carla, and Miller, K.G., 1984, EoceneOligocene boundary: Biostratigraphic recognition and gradual paleoceanographic change at DSDP site 549: Geology, v. 12, p. $112-115$.

Srivastava, S.K., 1972, Some spores and pollen from the Paleocene Oak Hill Member of the Naheola Formation, Alabama (U.S.A.): Review of Palaeobotany and Palynology, v. 14, p. 217-285.

Stainforth, R.M., Lamb, J.L., Luterbacher, Hanspeter, Beard, J.H., and Jeffords, R.M., 1975, Cenozoic planktonic foraminiferal zonation and characteristics of index forms: University of Kansas Paleontological Contributions, Article 62, 425 p.

Stanley, E.A., 1965, Upper Cretaceous and Paleocene plant microfossils and Paleocene dinoflagellates and hystrichosphaerids from northwestern South Dakota: Bulletins of American Paleontology, v. 49, no. 222 , p. 175-384.

Stenseth, N.C., and Maynard Smith, J., 1984, Co-evolution in ecosystems: Red Queen evolution or stasis?: Evolution, v. 38, p. 870880 .

Stenzel, H.B., 1935, A new formation in the Claiborne Group: University of Texas Bulletin 3501, p. 267-279.

1952, Correlation chart of Eocene at outcrop in eastern Texas, Mississippi, and western Alabama: Mississippi Geological Society Guidebook, 9th field trip, p. 32-33.

Sweet, W.C., 1979, Graphic correlation of Permo-Triassic rocks in Kashmir, Pakistan and Iran: Geologica et Paleontologica, v. 13, p. 239-248.

Sykes, L.R., McCann, W.R., and Kafka, A.L., 1982, Motion of Caribbean plate during last 7 million years and implications for earlier Cenozoic movements: Journal of Geophysical Research, v. 87 , no. B13, p. 10,656-10,676.

Thomas, E.P., 1942, The Claiborne: Mississippi Geological, Economic and Topographical Survey Bulletin 48, $96 \mathrm{p}$.

1948, The Jackson (Eocene) and younger beds of west-central Mississippi, in Mississippi Geological Society Guidebook, 6th field trip, June 18-20, 1948, p. 17-21.

Thomson, P.W., and Pflug, Hans, 1953, Pollen und Sporen des mitteleuropäischen Tertiärs: Palaeontographica, Abt. B, v. 94, p. 1138.

Tiffney, B.H., 1980, The Tertiary flora of eastern North America and the North Atlantic land bridge [abs.]: International Congress of Systematic and Evolutionary Biology, 2d, Vancouver, British Columbia, 1980, Abstracts, p. 373.

1981, Diversity and major events in the evolution of land plants, in Niklas, K.J., ed., Paleobotany, paleoecology, and evolution: New York, Praeger, v. 2, p. 193-230.

1985, The Eocene North Atlantic land bridge: Its importance in Tertiary and modern phytogeography of the Northern Hemisphere: Journal of the Arnold Arboretum, v. 66, p. 243-274.

Tomasini-Ortiz, A.C., and Martinez-Hernandez, Enrique, 1984, Palinologia del Eoceno-Oligoceno de Simojovel, Chiapas: Paleontologia Mexicana, no. 50, $61 \mathrm{p}$.

Toulmin, L.D., 1944, General features of the Tertiary formations in Alabama, in Southeastern Geological Society Guidebook, 1st field trip, southwestern Alabama, p. 5-15.

1962, Geology of the Hatchetigbee anticline area, southwestern Alabama, in Little Stave Creek-Salt Mountain field trip, Jackson, Ala., 12th Annual Meeting, New Orleans, 1962, Guidebook: New Orleans, La., Gulf Coast Association of Geological
Societies, p. 1-46.

1977, Stratigraphic distribution of Paleocene and Eocene fossils in the eastern Gulf Coast region: Geological Survey of Alabama Monograph 13, $602 \mathrm{p}$.

Traverse, Alfred, 1955, Pollen analysis of the Brandon lignite of Vermont: U.S. Bureau of Mines Report of Investigations 5151, $107 \mathrm{p}$.

Trewartha, G.T., 1968, An introduction to climate, 4th ed.: New York, McGraw-Hill, 408 p.

Tschudy, R.H., 1973, Stratigraphic distribution of significant Eocene palynomorphs of the Mississippi Embayment: U.S. Geological Survey Professional Paper 743-B, 24 p.

1975, Normapolles pollen from the Mississippi Embayment: U.S. Geological Survey Professional Paper 865, $42 \mathrm{p}$.

Vail, P.R., and Mitchum, R.M., Jr., 1979, Global cycles of relative changes of sea level from seismic stratigraphy, in Watkins, J.S., Montadert, Lucien, and Dickerson, P.W., eds., Geological and geophysical investigations of continental margins: American Association of Petroleum Geologists Memoir 29, p. 469-472.

Van Valen, Leigh, 1973, A new evolutionary law: Evolutionary Theory, v. 1, p. $1-30$

Vestal, F.E., 1956, Panola County geology: Mississippi Geological, Economic and Topographical Survey Bulletin 81, $157 \mathrm{p}$.

Waters, L.A., and Mancini, E.A., 1982, Lithostratigraphy and biostratigraphy of upper Eocene and lower Oligocene strata in southwest Alabama and southeast Mississippi: Gulf Coast Association of Geological Societies, Transactions, v. 32, p. 303-307.

Wei, K.-Y., and Kennett, J.P., 1986, Taxonomic evolution of Neogene planktonic foraminifera and paleoceanographic relations: Paleoceanography, v. 1, p. 67-84.

Wijmstra, T.A., 1968, The identity of Psilatricolporites and Pelliciera: Acta Botanica Neerlandica, v. 17, p. 114-116.

Willis, J.C., 1973, A dictionary of the flowering plants and ferns, 8th ed.: Cambridge University Press, 1,245 p.

Wing, S.L., 1984, A new basis for recognizing the Paleocene/Eocene boundary in western interior North America: Science, v. 226, p. 439-441.

Wing, S.L., and Hickey, L.J., 1984, The Platycarya perplex and the evolution of the Juglandaceae: American Journal of Botany, v. 71, p. $388-411$.

Wolfe, J.A., 1971, Tertiary climatic fluctuations and methods of analysis of Tertiary floras: Palaeogeography, Palaeoclimatology, Palaeoecology, v. 9, p. 27-57.

1975a, An interpretation of Tertiary climates in the Northern Hemisphere [abs.]: Geoscience and Man, v. 11, p. 160-161.

$-1975 \mathrm{~b}$, Some aspects of plant geography of the Northern Hemisphere during the Late Cretaceous and Tertiary: Missouri Botanical Garden, Annals, v. 62, p. 264-279.

1978, A paleobotanical interpretation of Tertiary climates in the Northern Hemisphere: American Scientist, v. 66, p. 694703.

1979, Temperature parameters of humid to mesic forests of eastern Asia and relation to forests of other regions of the Northern Hemisphere and Australasia: U.S. Geological Survey Professional Paper 1106, 37 p.

Wolfe, J.A., and Poore, R.Z., 1982, Tertiary marine and nonmarine climatic trends, in Climate in earth history: Washington, D.C., National Academy Press, p. 154-158. 


\section{INDEX}

[Italic page numbers indicate the beginning of descriptions and major references]

Page

\section{A}

abouziarovae, Intrabaculitricolporites ...... 54

Siltaria .............. 4, 48, 54; pl. 8 Aesculiidites circumstriatus ......... 4; pl. 7 afarus, Polypodi isporonites ............... 3

Aglaoreidia pristina ................... 3

Ailanthipites berryi ............... 5; pl. 16

Alangiaceae .......... 45, 56; pls. 11, 12, 13

Alangiopollis ....................... 56

eocaenicus...................... 56

simplex...................... $5 \pi$ sp. .......................... $5 \pi$

Alangium ........................ 56

Albany core, western Georgia ........21, 25, 29

alienus, Polypodiisporomites .............. 3

Almus vera ......................... 4

Amanoa .........................53,54

ampliapertura, Globigerina .............. 37

Anacolosidites claibornensis ......... 4; pl. 5

rehlawensis ................ 4, 5:; pl. 5

sp. $1 \ldots \ldots \ldots \ldots \ldots \ldots \ldots \ldots \ldots . . \ldots$; pl. 5

anguloluminosus, Retitrescolpites............ 4

Annutriporites rotundus............... 51

anulatus anulatus, Subtriporopollenites.... 52

anulatus, Subtriporopollenites ......... 3,51

Subtriporopollenites anulatus .........5.52

Aquia Formation .......................5z

Araliaceoipollenites ...................... 2

granulatus ....................... 4

profundus. ...................... 4

araneosa, Rousea ...................... 4

arcuata, Symplocos.................... 5

Arecipites rousei $\ldots \ldots \ldots \ldots \ldots \ldots \ldots \ldots \ldots 4$

asper. Tricolpites .................... 4

auriculoides, Ilexpollenites.......... 4: pl. 10

\section{B}

buculoferus, Faritricolporites .............. 5 barbadieusis, Discoaster ................. 35 barghournianus. Cyrillaceaepollenites ...... 4

Barton Beds, England ................. 47 Bashi Formation ............ 8, 10, 14, 23, 35 Bashi-Hatchetigbee Interval .... 11, 19, 38, 43 Basic City Shale Member, Tallahatta

Formation ................., 8,11

berryi, Ailanthipites............... 5; pl. 16

Betula infrequens .................... 49

Betulaceae.........................49

Betulaceoipollenites ...................49

infrequens ...................... 49

Betulaepollenites complex.

Paraalnipollenites-............... 49

bituitus, Pollenites...................... 49
Page

bituitus excelsus, Pollenites............... 49

bituitus granifer. Pollenites .............. 49

Boehlensipoll is gramulate .......... 55, pl. 10 hohlii....................... 5, 55 verrucuta ................ 5, 48; pl. 10

Bombacaceae .................... 45, 58

Bombacacidites fereparilis.......... 5: pl. 15

hungaricus .................... 58

kettigensis minimus ............... 58

nacimientoensis .............5. 58; pl. 15

nanobrochatus ................ 5; pl. 15

reticulatus .................... 5; pl. 15

tilioides ........................ 58

sp. $1 \ldots \ldots \ldots \ldots \ldots \ldots \ldots \ldots$; pls.14, 15

sp. $2 \ldots \ldots \ldots \ldots \ldots \ldots \ldots \ldots \ldots$; pl. 14

Bombapollis terensis .............. 5; pl. 14

Bracklesham Beds. England ............ 47

brevis, Tetracolporopollenites ........ 5; pl. 16

brecisulcatum, Chrysophyllum .......... 4, 53

Brightseat Formation ................ 50

Brosipollis striata............4, 48 ; pls. 3,4

other striate species . ........... 4; pl. 4

striatobrusus.................... 52

Bumpnose Formation .................. 2

Bursera ............................ 52

Burseraceae ......................52

\section{C}

Calcareous nannofossil zones. See Fossil zones.

capar, Rhoipites ..............5, 48; pls. 13, 14

Caprifoliipites tantulus................. 5

Carya ............................. 3

Cusuarina pulchru ...................49

Casuarinaceae .................... 49

Casuarinidites....................... 49 sparsus....................... 51

catatumbus, Retibrecitricolpites .......... 5.3

ceciliensis, Intratriporopollenites ......... 58

Symplocos ....................... 5

Cedrus piniformis...................... 3

Celtipollenites gracilis............4,48; pl. 3

Celtis sabinetownensis ................. 48,51

texensis...................... 51

tschudyi ..................... 4,51 ; pl. 3

cerroazulensis, Turborotalia ........... 35, 36

Chenopodipoll is spp .................. 4

Chrysophyllum brerisulcatum ........... 4, 5.3

circumstriatus, Afseuliidites .......... 4; pl. 7

claibornensis, Anacolosidites.......... 4; pl. 5 Nurpollenites ..................... 4

Claibornian Stage .............. 2, 19, 25, 29

claricristata, Eyhedra ..................... 3

Clethraceae ......................... 56

Cockfield or Cook Mountain Formation,

western Mississippi ..........2, 10, 27
Page

cockfieldensis, Gothanipoll is ............. 5

Cocoa Sand Member, Yazoo Clay........ 1, 35

compacta, Comptonia.................. 50

compactus, Triatriopollenites. .....48,50; pl. 1

Composite standard section ............ 1, 32

Comptonia .......................... 50

compacta ....................... 50

peregriniformis .................. pl. 1

concans, Undulatisporites ............... 3

Confertisulcites fusiformis .............. 4

confusus, Paraalmipollenites .......... 3; pl. 3

conspicuus, Parsonsidites ............... 4

constans constans, Subtriporopollenites ..... 5.3

constans, Subtriporopollenties constans .....53

contracta, Symplocos .................. 55

convexus, Triatriopollenites ........49, 50; pl. 2

Cook Mountain Formation, See also

Cockfield Formation ............ 25

Cordyloblaste ........................ 5.5

Corollina spp ........................ 3

Corsinipollenites oculus-noctis . ....... 3; pl. 3

parriangulus ..................... 3

verrucatus ................. 4, 48; pl. 4

sp .......................... pl. 3

coryloides, Momipites .................2 crassa, Lanagiopollis.......... 5, 48, 56; pl. 11 crassus, Psilatricol porites ............. 56 crebellatus, Margocolporites............. 56 cribellata, Lanagiopoll is ............ 48; pl. 11 crockettensis, Nurpollenites ............. 4 Crotonipollis........................ 48

Crystal River Formation . . . . . . . . . . . 43

Cubitostrea lisbonensis ................. 39 sellaeformis....................... 39

Cupanieidites orthoteichus ............... 5

Cupuliferoidaepollenites ................. 2

Cupuliferoipollenites .................... 2

Cusseta Sand. Campanian ................ 18

Cyathea starensis .................... 3

Cyrillaceaepollenites barghoornianus... 4 ; pl. 8 kedeesii ........................ 54 megaeractus ................. 4; pl. 8

\section{D}

Dicolpopollis spp ................. 4; pl. 6 Diporites sp. 1 .................. 3; pl. 1 sp. $2 \ldots \ldots \ldots \ldots \ldots \ldots \ldots \ldots \ldots \ldots$ Diporoconia iszhaszentgyoegyi ........... 48

Discoaster barbadiensis ................. 35 mohleri......................... 34 suipanensis...................... 35

discrepans, Triporopollenites ............ 49 Dobys Bluff Tongue, Kosciusko

Formation ................. 9, 13

draco, Rhombodinium .................... 35

duploreticulatus, Friedrichipollis ....... pl. 16 
Page

E

Early Eocene event $\ldots \ldots \ldots \ldots \ldots \ldots \ldots, 1,44$

Echitriporites sp ...................... pl. 5

spp.......................... pl. 4

Emmapollis sp. 1 ................ 3; pl. 1

Engelhardia ........................ 46

Enopadios reticulatus .............. 4; pl. 7

eocaenica, Lanagiopollis ............. 5, 48

eocaenicus, Alangiopollis ............... 56

Eocene-Oligocene boundary, Gulf Coast ................ 11, 36

Ephedra claricristata ................... 3 exiguua ....................... 3

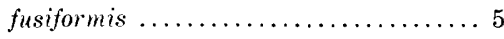

hungarica ....................... 3

Ephedripites (Spiralipites) spp ....... 3; pl. 1

Ericipites ericius .................... 32

ericius, Ericipites ..................... 32

Eисотmia................... 4; pls.7.8

Euphorbiaceae..................... 48

excelsus, Pollenites bituitus............... 49

exigura, Ephedra ..................... 3

\section{F}

Fagaceae ........................ 46

Favitricol porites baculoferus............. 5

Fanoisporis sp ...................... pl. 1

farus, Polypodiisporonites ............... 3

fereparilis, Bombacacidites .......... 5; pl. 5

Ficus spp. ....................... 48

fissuratus, Trivestibulopollenites .......... 50

flexus, Momipites ...................... 3

Forest Hill Formation................. 2

Fossil zone NP9 (calcareous nannofossil).... 34 NP10................. 14, 16, 22, 34

NP11............. 16, 22, 34, 38, 39

NP12......... 12, 16, 22, 34, 38, 42, 45

NP13.............. 12, 16, 34, 39, 42

NP14................. 12, 16, 34, 42, 45

NP15 ................ 16, 34, 39, 42

NP16....................... 34

NP17,................ 34, 40, 43, 46

NP18................... 35, 43

NP19...................... 35, 42

NP20 $\ldots \ldots \ldots \ldots \ldots \ldots \ldots \ldots, \ldots, 42$

NP21.................... 35, 46

Fossil zone P11 (planktic foraminifer) ..... 35

P12 ......................... 35

P14 ......................... 35

P15 ......................... 35

P16 ........................ 35, 37

P17 ........................... 35, 37

Friedrichipollis duploreticulatus ........ pl. 16

sp .......................... pl. 16

sp. $1 \ldots \ldots \ldots \ldots \ldots \ldots \ldots \ldots \ldots$; pl. 16

fusiformis, Confertisulcites................. 4

Ephedra ....................... 5

G

galiformis, Myrica ................... 50 Triatriopollenites ............ 38,$50 ; \mathrm{pl} .2$ gemmata, Symplocos ................... 5

Geochronologic section ..................

Globigerina ampliapertura .............. 37
Page

Page

globosa, Labrapollis .................... 3

Gosport Formation ......... 2, 14, 25, 34, 40

Gothanipollis cockfieldensis .............. 5

redactus ..................... $5 ;$ pl. 10

gracilis, Celtipollerites ............. 4, 48; pl. 3

Graminidites spp ..................... 3 granifer, Pollenites bituitus .............49 49 granilabratus, Triatriopollenites .......... 50 gramulata, Boehlensipoll is .......... 55; pl. 10 Granulatisporites luteticus ............... 3 gramulatus, Araliaceoipollenites.........., 4 Graphic correlation .................. 6

\section{H}

hadrodictya, Lanagiopoll is ......5, 48; pl. 13 Haloragacidites .................. 49 Hantkenina $\operatorname{spp} \ldots \ldots \ldots \ldots \ldots \ldots \ldots \ldots$

Hatchetigbee Formation ....... 9, 11, 14, 35 Headon Beds, England ............. 47 hohlii, Boehlensipollis ..............5,55 hungarica, Ephedra .................. 3

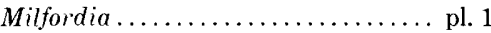
hungaricus, Bombacacidites...........58

\section{I}

Ilexpollenites auriculoides .........4; pl. 10 inamoenus. Quercoidites ................. 4 incerta, Milfordia .................. 3 infrabaculatus, Juglanspollenites. .........4 infrequens, Betula ................... 49 Betulaceoipollenites ............... 49 Triporopollenites............. 48, 49 insculptus, Intratriporopollenites........58 instructus, Intratriporopollenites .......... 5 interangulus, Tricolpites .......... 4; pl. 7 Interpollis microsupplingensis .......... Intrabaculitricolporites............... 54 abouziarorae....................54

Intratriporopollenites ceciliensis ........58

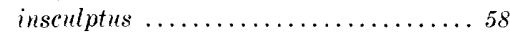
instructus.................. 5 mimimus .................... 58 pseudinstructus $\ldots \ldots \ldots \ldots \ldots \ldots, 5,58 ;$ pl. 15 stavensis...............5,58; pl. 15 sp. $1 \ldots \ldots \ldots \ldots \ldots \ldots \ldots \ldots$; pl. 16 iszkaszentgyoergyi, Diporoconia ........48

Jackson fault ................. 11, 34 Jacksonian Stage $\ldots \ldots \ldots \ldots \ldots \ldots \ldots 1,2,25,29$ jacksoniana, Symplocos........... 5; pl. 9 Jarzenipollis trina $\ldots \ldots \ldots \ldots \ldots \ldots \ldots \ldots . \ldots$ Juglandaceae ................... 45, 46 Juglans nigripites ................. 4 Juglanspollenites infrabaculatus ........ 4

K

kedvesii, Cyrillaceaepollenites..........54 kettigensis mimimus, Bombacacidites ..... 58
Kosciusko Formation ............. 1, 9, 25

krempii, Ulmipollenites ............. 3

$\mathrm{L}$

Labrapollis globosa................. 3

Lanagiopollis .................. 56 crassa ............. 5, 48, 56; pl. 11 cribellata ................48; pl. 11 eocaenica ........... 5, 48; pls. 12,13 hadrodictya............... 5, 48; pl. 13 lihoka ...................... 48 sp. $1 \ldots \ldots \ldots \ldots \ldots \ldots \ldots \ldots \ldots$; pl. 12 sp. $2 \ldots \ldots \ldots \ldots \ldots \ldots \ldots \ldots \ldots$; pl. 12 latus, Rhoipites .............. 5,54 laxa, Ruellia ................... 4 lesquereuxianus, Tetracolporopollenites ..... 5 lihoka, Lanagiopoll is ................. 48 lihokus, Margocolporites . ............ 56 Liliacidites vittatus ................. 4 Lisbon Formation . . . . . . 1, 8, 13, 24, 32, 39 lisbonensis, Cubitostrea .............. 39 Little Stave Creek, western

Alabama ......... 9, 10, 24, 29, 32, 39 London Clay Beds, warming episode.

Ypresian .................. 47 Longapertites spp ............. 4; pls. 5, 6 longipollinia, Manilkara ............ pl. 16 lubomirorae, Triatriopollenites...... 3, 50; pl. 2 Lutetian-Bartonian boundary ........... 35 luteticus, Granulatisporites ............ 3 Lycopodium venustum .................. 3 Lymingtonia rhetor................ 4

\section{M}

macgregorii, Pistillipollenites ............ 3 magnifica, Thomsonipoll is ............ 4 magniorbicularis, Plicatopollis....... 3; pl. 2 magnoporatus, Subtriporopollenites .......51 Malvacipollis tschudyi ........... 4; pl. 5 Manilkara longipollinia ............. pl. 16

Maryocolporites.................. 56 cribellatus . .................... 56 lihokus ........................ 56

Marlboro Clay .................. 52 megadolium, Tetracol poropollenites ... 4; pl. 8 megaexactus, Cyrillaceaepollenites .... 4; pl. 8 megarobustus, Triporopollenites ........550 Meridian Sand Member, Tallahatta

Formation ................... 12

Microforeolatosporis pseudodentata ....... 3 microfoveolatus, Momipites ............ 2 microsupplingensis, Interpollis.........4

Middle Eocene event .............. 1,45

Milfordia hungarica $\ldots \ldots \ldots \ldots \ldots \ldots \ldots$ pl. 1

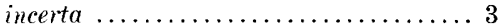
minima $\ldots \ldots \ldots \ldots \ldots \ldots \ldots \ldots \ldots \ldots$ minima, Milfordia .................. 3 minimus, Bombacacidites kettigensis ..... 58 Intratriporopollenites ........... 58 mohleri, Discoaster . .................. 34

Momipites coryloides .............. 2 flexus......................... 3 microfoveolatus .................. 2 strictus $\ldots \ldots \ldots \ldots \ldots \ldots \ldots \ldots \ldots \ldots 20$ tenuipolus (Paleocene type) ............ 3 tenuipolus (Platycaryapollenites type) .. 3 
Momipites-Plicatopollis-

Platycarya pollenites complex ........ 3 monilifera. Rousea .................... 4

Moraceae ....................... 48

Morozovella subbotinae Interval Zone ...... 35

Myrica ............................. 50 galiformis ....................... 50 paradoxa ........................50

Myricaceae ........................ 49

Myrtaceidites parrus .................. 5

$\mathrm{N}$

nacimientoensis, Bombacacidites ....... 5, 58 Naheola Formation, Oak Hill Member ..... 10 nanobrochatus, Bombacacidites ...... 5; pl. 15 nanus, Subtriporopollenites .......... 3; pl. 3 Neshoba Sand Member, Tallahatta Formation ................... 12 nigripites, Juglans ................ 4 Niklas, Knoll, and Tiffney, data biases ........................ 40

North Twistwood Creek Member, Yazoo Clay ..................... 35

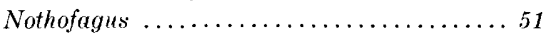
tschudyi ................... 51

Nudopollis terminalis ................. 5

Nuxpollenites claibornensis . ............. 4 crockettensis .................... 4 psilatus ...................... 4

Nyssapollenites ................. pl. 10 spp. $1-4 \ldots \ldots \ldots \ldots \ldots \ldots \ldots \ldots$ pl. 11

Oak Hill Member, Naheola Formation .... 10 Ocala Limestone ....................... 18 occidentaloides, Plantunus ............. 4 oculus-noctis, Corsinipollenites ........ 3; pl. 3 Oligocene deterioration ............ 46 ollivierae. Porocolpopollenites

(tetracolporate) ............... 5

Porocolpopollenites (tricolporate) ....... 5 orthoteichus, Cupanicidites .............5

$\mathrm{P}$

pacata, Siltaria................... 54 Pachuta Marl Member, Yazoo Clay ...... 35 palaeobetuloides.

Triporopollenites.......... 3, 49; pl. 2

Paleocene-Eocene contact.............. 15

papillatum, Pemma ................ 37 Paraalnipollenites-

Betulaepollenites complex ..........49 Paraalnipollenites confusus .......... 3 ; pl. 3 paradoxa, Myrica ...................50 paradoxus, Triatriopollenites . . . 3, 48, 50; pl. 2 Parsonsidites conspicuus ................ 4 pariangulus, Corsinipollenites .......... 3 parvus, Myrta ceidites ............... 5 Pelliceria ........................ 56 Pelliceriaceae.................... 56 Pellicieroipollis .................... 56 Pemma papillatum .................. 37 peregriniformis, Comptonia........... pl. 1 piniformis, Cedrus .................. 3 Pistillipollenites macgregorii............ 3

Planera .......................... 51 thompsoniana .................. 51 Planktic foraminifer zones. See Fossil zones

Platanus occidentaloides............... 4

Platycarya ........................51 platycaryoides $\ldots \ldots \ldots \ldots \ldots \ldots \ldots \ldots, 5,51$

Platycaryapollenites................... 51 swasticoidus .................. 3 triplicatus ................. 3; pl. 2

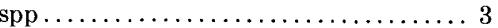

Platycaryapollenites-Momipites-

Plicatopollis complex ............ 3

platycaryoides, Platycarya ............. 51

Plicatopollis magniorbicularis ........ 3; pl. 2 triorbicularis ................ 3 triradiata ..................... 3

Plicatopollis-Platycaryapollenites complex, Momipotes- ............. 3

Pollenites bituitus ..................... 49 bituitus excelsus . . . . . . . . . . . 49 gramifer .................... 49

Polyatriopollenites vermontensis ........4 4

Polycolpites $\mathrm{sp}$.................. pl. 7

Polypodiisporonites afarus ............ 3

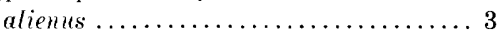
far $u s \ldots \ldots \ldots \ldots \ldots \ldots \ldots \ldots \ldots \ldots, \ldots \ldots$

Porocolpopollenites ................ 55 ollivierae (tetracolporate) ............5 5 ollivierae (tricolporate) ............. 5 virginiensis .................... 55 sp. $1 \ldots \ldots \ldots \ldots \ldots \ldots \ldots \ldots \ldots$; pl. 8

Priabonian Stage ................ 35 pristina, Aglaoreidia .................. 3 profundus, Araliaceoipollenites ......... 4 prolatus, Tetracolporopollenites . . . 4, 48; pl. 8 prominatus, Spinizonocolpites ..........4 4 Prorapertites $\mathrm{spp} \ldots \ldots \ldots \ldots \ldots \ldots \ldots 4$; pl. 6 pseudinstructus,

Intratriporopollenites .....5,58; pl. 15 pseudodentata, Microfoveolatosporis ........ 3 Pseudolaesopollis ventosa .............. 4 pseudoroboratus, Triatriopollenites ........ 51 Psilatricol porites crassus . ............ 56 psilatus, Nurpollenites .............. 4 pulcher, Triporopollenites........3, 48, 49; pl. 2 pulchra, Casuarina ............... 49

\section{Q}

Quercoidites .................... inamoemus....................... 4

\section{$\mathrm{R}$}

Red Bluff Formation ................ 2 Red Queen model of evolution ......... 1, 47 redactus, Gothanipollis ........... 5; pl. 10 Reevesiapollis $\operatorname{spp} \ldots \ldots \ldots \ldots \ldots \ldots \ldots \ldots 4$; pl. 5

Regulitriporites spp. $1 \ldots \ldots \ldots \ldots \ldots \ldots \ldots 2$

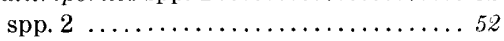
spp. $3 \ldots \ldots \ldots \ldots \ldots \ldots \ldots \ldots \ldots \ldots, \ldots \ldots$ Reklaw Formation, Tallahatta equivalent ....................24 reklawensis, Anacolosidites ......4,52; pl. 5
Retibrentricolpites catatumbus.........53 simplex.............. 4, 48; pl. 7 sp $\ldots \ldots \ldots \ldots \ldots \ldots \ldots \ldots \ldots$ pls. 7,16 reticlavata, Reticulataepollis...........5 reticulata, Reticulofenestra.............. 35 Reticulataepollis reticlavata $\ldots \ldots \ldots \ldots \ldots .5$ reticulatus, Bombacacidites ............. 5

Enopadios ............... 4; pl. 7 Sparganiaceaepollenites ......... 3; pl. 1 Tricolpites ................. 4; pl. 7

Reticulofenestra reticulata ............ 35

Retitrescolpites anguloluminous .......... 4

Retitriporites $\mathrm{sp} \ldots \ldots \ldots \ldots \ldots \ldots \ldots \ldots$ pl. 3 sp. $18 \ldots \ldots \ldots \ldots \ldots \ldots \ldots \ldots \ldots \ldots \ldots$ pl. 3

rhetor, Lymingtonia ............... 4 Rhoipites capa. .......... 5, 48; pls. 13,14 latus ................... 5, 54 subprolatus ................. 5

Rhombodinium draco................ 35

rotundus, Annutriporites .............51

Rousea araneosa ................ 4 monilifera ...................... 4

rousei, Arecipites . ................ 4

Ruellia laxa ...................... 4

rurensis, Triatriopollenites ............50

\section{$\mathrm{S}$}

sabinetownensis, Celt is ........... 48, 51

Thomsonipollis............... 51 Sabinian Stage, upper . ............ 19, 38 saipanensis, Discoaster ............. 35 Salixipollenites parvus .............. 4

Sapotaceae ....................... 45 Scutella Beds .................... 35 sellaeformis, Cubitostrea ........... 1, 29, 39 Selsey Formation, England .......... 47 Shubuta Member, Yazoo Clay ....... 1, 32, 35 Siltaria ........................ 2 abouziarorat ............4, 48,54; pl. 8 pacata..........................54 simplex, Alangiopollis............. $5 \%$ Retibrevitricolpites ..........4, 48; pl. 7 Sparganiaceaepollenites reticulatus . . . 3; pl. 1 sparsus, Casuarividites ...............51

Triatriopollenites ..........3, 48,50; pl. 2 Sparta Sand $\ldots \ldots \ldots \ldots \ldots \ldots \ldots \ldots \ldots \ldots \ldots .9$ Sphagnum triangularum .............. 3 Spinizonocolpites prominatus .......... 4 (Spiralipites) Ephedripites ............. 3 Standard reference section. See also Little Stave Creek.............. 10 Stationary model of evolution ......... 1,47 stavensis, Cyathea ................. 3 Intratriporopollenites .......5,58; pl. 15 Steenesipollenites $\mathrm{sp} \ldots \ldots \ldots \ldots \ldots \ldots \ldots$ pl. 1 Sterculiacene ....................58 striata, Brosipollis . ........ 4, 48; pls. 3, 4 striatobrosus, Brosipoll is ............ 52 Striatopollis terasmaei ................ 4 strictus, Momipites .................. 20 subbotinae Interval Zone, Morozovella ..... 35 subporatus, Subtriporopollenites ........51 subprolatus, Rhoipites .............. subtriangulus, Triatriopollenites ...... pls. 1, 2 Subtriporopollenites anulatus . ....... 3,51 amulatus anulatus.................52 constans constans ................53 magnoporatus................ 51 namus ..................... 3 ; pl. 3 


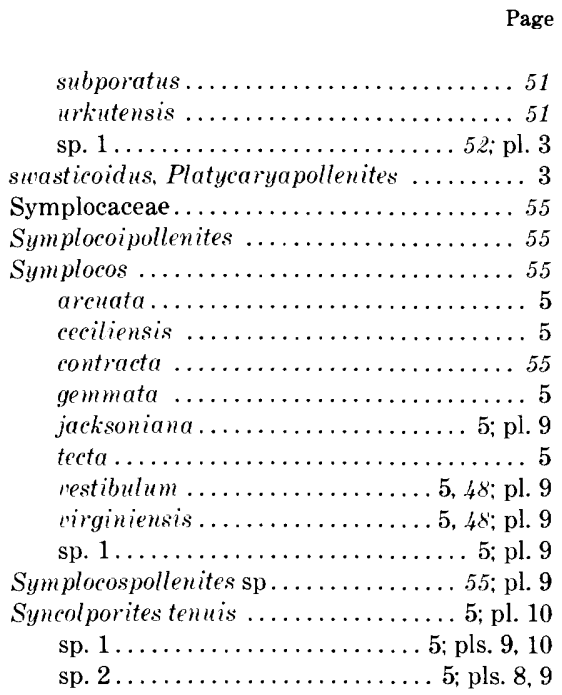

$\mathrm{T}$

Tallahatta Formation ....1, 8, 11, 21, 24, 38, 43 tantulus, Caprifoliipites................ 5 tecta, Symplocos................. tenuipolus, Momipites

(Platycaryapollenites type)...... 3; pl. 2 Momipites (Paleocene type) . . . . . . 3; pl. 2 tenuis, Syncolporites.............. 5; pl. 10 terasmaei, Striatopollis ............. 4 Terminal Eocene event ............. 1, 46 terminalis, Nudopollis............... 5 Tetracolporopollenites brevis ........ 5; pl. 16 lesquereuxianus .............. 5; pl. 16 megadolium (short colpi).......... 4; pl. 8 (long colpi) .................. 4 prolatus ............... 4, $48 ;$ pl. 8 texensis, Bombapollis .............. 5; pl. 14

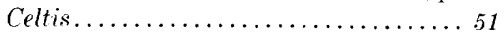
Theaceae ........................ 56

thompsoniana, Planera ...............51 thompsonianus, Ulmipollenites........ 3, 48

Thomsonipollis magnifica ............. 4 sabinetownensis .............. 51
Page

Tiliaceae ....................45,58

tilioides, Bombacacidites .............58

triangularum, Sphagnum ............... 3

triangulus, Triatriopollenites ......... pl. 2

Triatriopollenites compactus . . . . .48, 50; pl. 1 convexus............... 3, 49,50; pl. 2 galiformis ............. 48,50; pl. 2 granilabratus ................. 50 lubomirovae ........... 3,50; pl. 2 paradoxus .............. $4,4,50 ;$ pl. 2 pseudoroboratus ................... 51

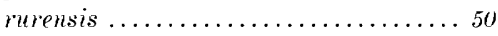
sparsus ................ 3, 48, 50; pl. 2 subtriangulus ............... pls. 1,2 triangulus ................. pl. 2

turgidus .......................

sp ......................... 1

Tricolpites asper ........................4 interangulus ............... 4; pl. 7 reticulatus .................. $4 ;$ pl. 7

tricostatus, Llmipollenites ........... 3 trina, Jarzenipollis.................. triorbicularis, Plicatopollis ............. 3 triplicatus, Platycaryapollenites ........ 3 ; pl. 2

Triporopollenites................... 49

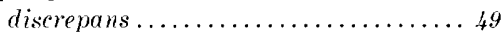
infrequens ................. 48,49 megarobustus .................. 50 palaeobetuloides............ 3, 49; pl. 2 pulcher ................ 48, 49; pl. 2

triradiata, Plicatopollis . ............ 3

Trivestibulopollenites .................49 fissuratus................... 50 tschudyi, Celtis (triporate) ........ 3, 50; pl. 3 Celtis (multiporate) ..........4, 51; pl. 3 Maliacipollis ............. 4; pl. 5

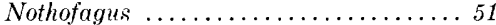

Turborotalia cerroazulensis ........... 35 turgidus, Triatriopollenites ............ 3

\section{$\mathrm{U}$}

Ulmaceae $\ldots \ldots \ldots \ldots \ldots \ldots \ldots \ldots \ldots 45,51$

Ulmipollenites krempii ............... 3 thompsonianus............... 4,48 tricostatus $\ldots \ldots \ldots \ldots \ldots \ldots \ldots \ldots \ldots \ldots$

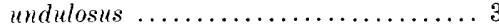

Undulatisporites concavus ............. 3

undulosus, Ulmipollenites ...............

urkutensis, Subtriporopollenites .........51

\section{V}

rentosa. Pseudolaesopollis .............4 venustum, Lycopodium ............... 3 vera, Almus ......................... 4 vermontensis, Polyatriopollenites ..........4 verrucata, Boehlensipollis.........5, 48; pl. 10 verucatus, Corsinipollenites ......4,48; pl. 4 Verrutricol porites ................. 2 vestibulum, Symplocos ............ 5; pl. 9

Vicksburgian Stage .............. 2, 29 virginiensis, Porocolpopollenites.........55 Symplocos ............... 5, 48; pl. 9 vittatus, Liliacidites............... 4

\section{W}

Winona Formation .............. 8, 25 Wittering Formation, England ......... 47

Y

Yazoo Clay ................. 1, 14, 31, 35

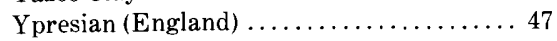
Z

Zelkova...................... 51

Zilpha Clay ...................... 8 Zone I (Claibornian, Jacksonian Stages) ...................... 31

Zone II (Jacksonian, Vicksburgian Stages) ........................ 31

Zone, Cubitostrea sellaeformis ........... 29 


\section{PLATES 1-16}

Contact photographs of plates 1-16 are available, at cost, from the U.S. Geological Survey Library, Federal Center, Denver, CO 80225. 


\section{PLATE 1}

[Magnification $\times 1,000]$

FIgURES 1-4. Favoisporis? sp. The distal face is densely granulate; the proximal face is psilate. Bashi Formation, eastern Alabama. 5. Ephedripites subgen. Spiralipites sp. (OTU 33). Bashi Formation, eastern Alabama.

6-9. Sparganiaceaepollenites cf. S. reticulatus Krutzsch \& Vanhoorne 1977 (OTU 45). 6, 7, Hatchetigbee Formation, western Georgia; 8, Bashi Formation, eastern Alabama (interference contrast); 9, Hatchetigbee Formation, western Alabama. 10, 11. Steevesipollenites sp. Interference contrast; Lisbon Formation, western Alabama.

12. Milfordia hungarica (Kedves 1965) Krutzsch \& Vanhoorne in Krutzsch 1970 (OTU 39). Lisbon Formation, western Alabama. 13-16. Emmapollis sp. 1 (OTU 49). 13, 14, Tallahatta Formation, western Alabama; 15, 16, Albany core, western Georgia.

17. Diporites sp. 1 (OTU 51). Lisbon Formation, western Alabama.

18, 19. Triatriopollenites compactus (Gladkova 1965) n. comb. (OTU 61). Lisbon Formation, western Alabama.

20. Triatriopollenites sp., having the large rather deep atrium of $T$. compactus combined with the more definite tumescence or annulus of "Comptonia" peregriniformis Gladkova 1965. Lisbon Formation, western Alabama.

21, 22. Triatriopollenites cf. T. subtriangulus (Stanley 1965) Frederiksen 1979. This specimen has a thicker annulus than $T$. subtriangulus. Lisbon Formation, western Alabama. 
DEPARTMENT OF THE INTERIOR

U.S. GEOLOGICAL SURVEY

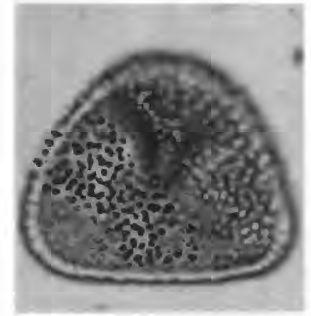

1

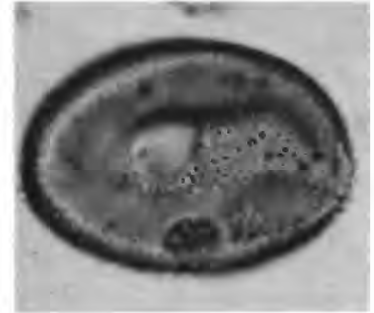

6

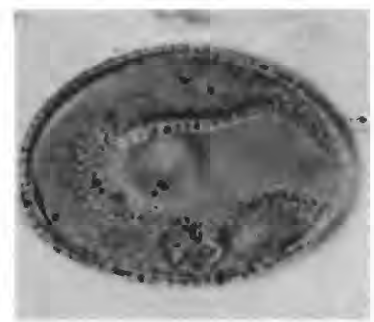

7

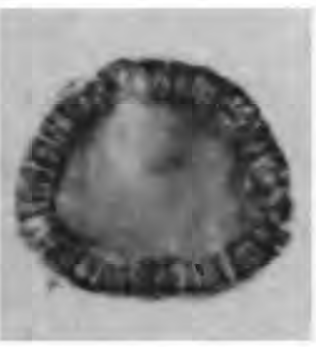

13

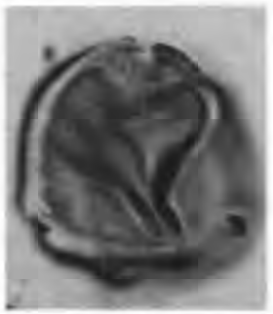

18

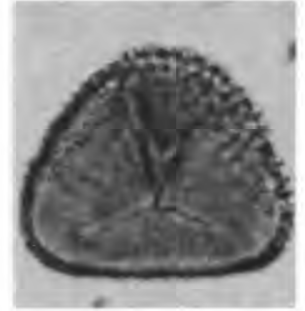

2

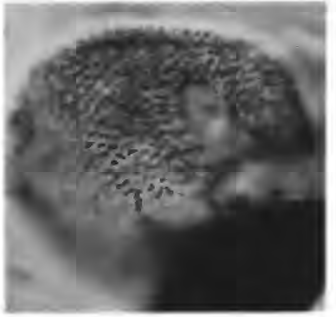

8
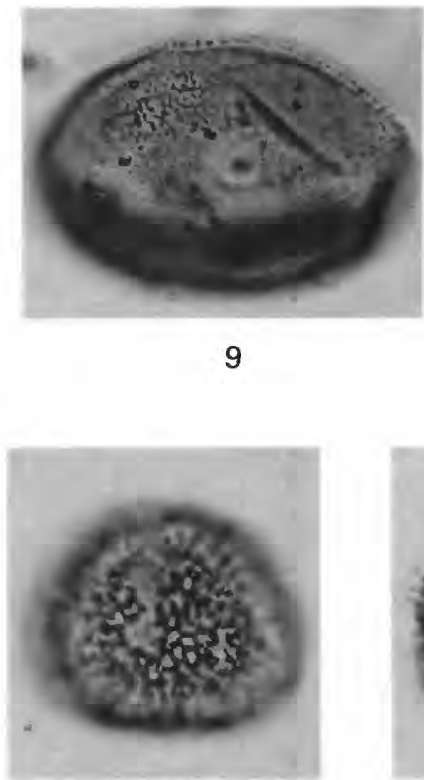

14

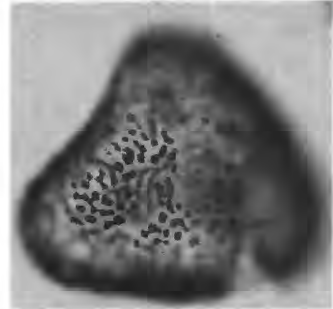

3

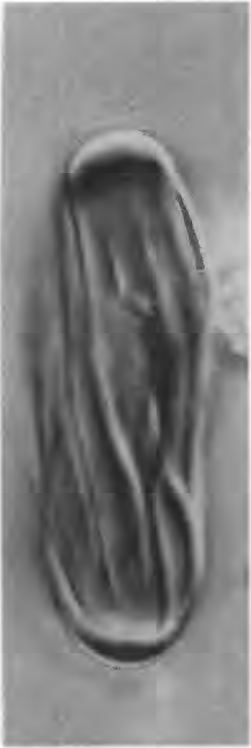

10

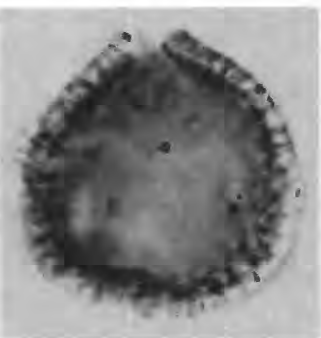

15

PROFESSIONAL PAPER 1448

PLATE 1

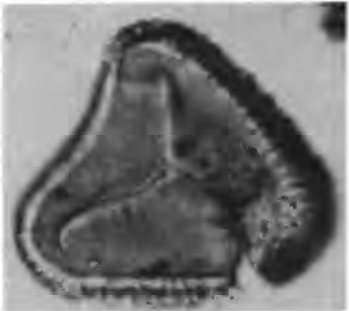

4

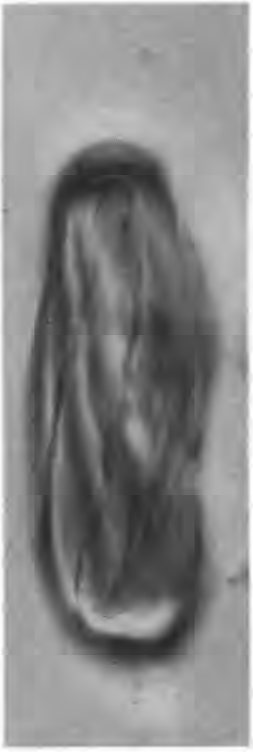

11

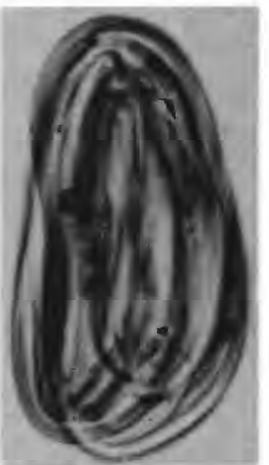

5

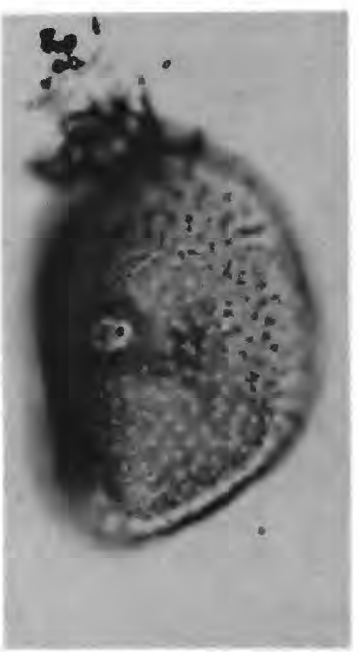

12

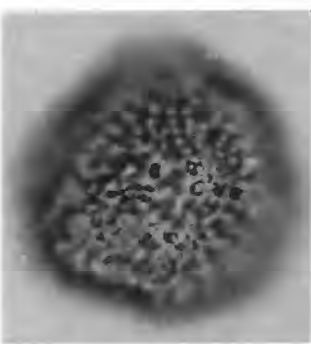

16

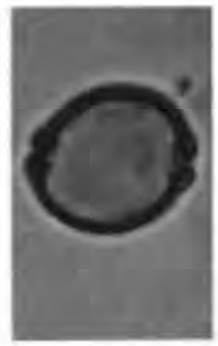

17

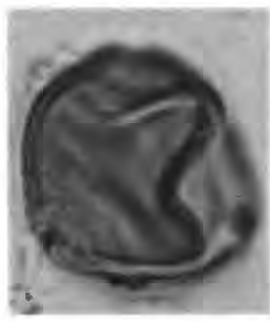

19

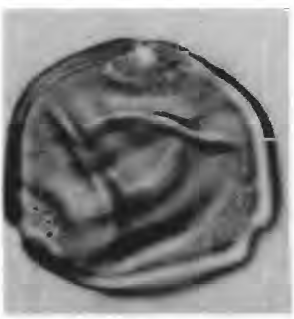

20

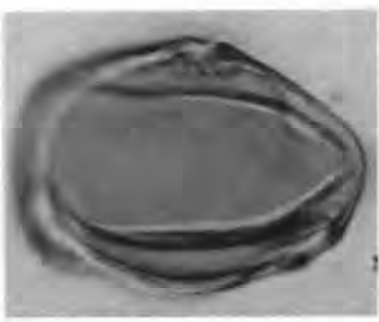

21

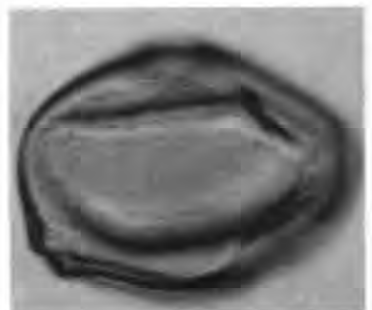

22

SPORES AND POLLEN GRAINS 
PLATE 2

[Magnification $\times 1,000$ ]

FIGURE 1. Triatriopollenites cf. T. subtriangulus (Stanley 1965) Frederiksen 1979. This specimen has a thicker exine than T. subtriangulus. Lisbon Formation, western Alabama.

2-4. Triatriopollenites lubomirovae (Gladkova 1965) Kedves 1974 (OTU 65). 2, Basic City Shale Member, Tallahatta Formation, eastern Mississippi; 3, Bashi Formation, eastern Alabama; 4, Albany core, western Georgia.

5-8. Triatriopollenites galiformis (Gladkova 1965) n. comb. (OTU 63). 5, 8, Lisbon Formation, western Alabama; 6, 7, Albany core, western Georgia.

9. Triatriopollenites aff. $T$. triangulus Frederiksen 1979. This specimen has more convex sides and a slightly more prominent labrum than typical $T$. triangulus. Lisbon Formation, western Alabama.

10. Triatriopollenites sparsus group (OTU 69). Albany core, western Georgia.

11, 12. Triporopollenites pulcher group (OTU 57). 11, Hatchetigbee Formation, eastern Alabama; 12, Bashi Formation, eastern Alabama.

13, 14. Triatriopollenites convexus group (OTU 59). 13, Tallahatta Formation, western Georgia; 14, Albany core, western Georgia.

15, 16. Triporopollenites palaeobetuloides group (OTU 55). Lisbon Formation, western Alabama.

17-20. Triatriopollenites paradoxus (Gladkova 1965) n. comb. (OTU 67). 17, 20, Tallahatta Formation, western Georgia; 18, Albany core, western Georgia; 19, Hatchetigbee Formation, western Georgia.

21. Platycaryapollenites triplicatus (Elsik 1974) Frederiksen \& Christopher 1978 (OTU 85). Hatchetigbee Formation, western Alabama.

22. Momipites tenuipolus group (Paleocene type) (OTU 79). This type has a distinct polar island on at least one face, but there is no evidence of pseudocolpi. Basic City Shale Member, Tallahatta Formation, eastern Mississippi.

23-25. Momipites tenuipolus group (Platycaryapollenites type) (OTU 77). This type has a polar island on at least one face, but the "moat" around the island appears to be formed of pseudocolpi. 23, 25, interference contrast. 23, Tallahatta Formation, western Alabama; 24, Albany core, western Georgia; 25, Hatchetigbee Formation, western Alabama.

26, 27. Plicatopollis magniorbicularis Frederiksen 1983 (OTU 91). 26, Albany core, western Georgia; 27, Tallahatta Formation, western Alabama (interference contrast). 


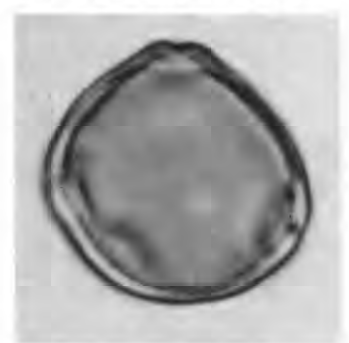

1

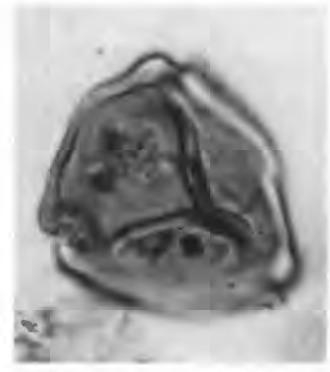

6

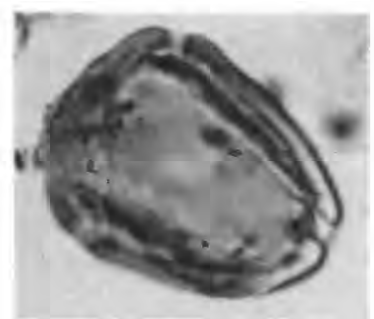

11

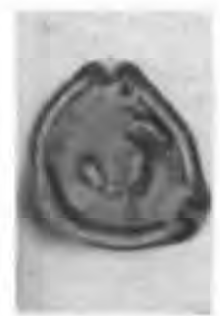

17

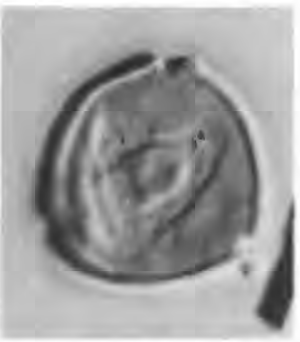

23

18

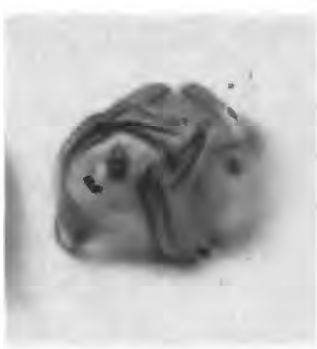

2

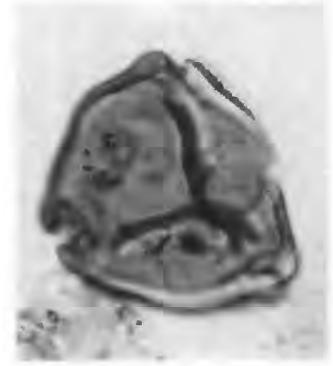

7

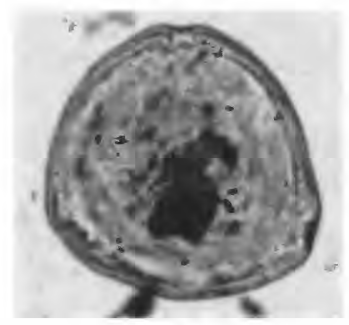

12
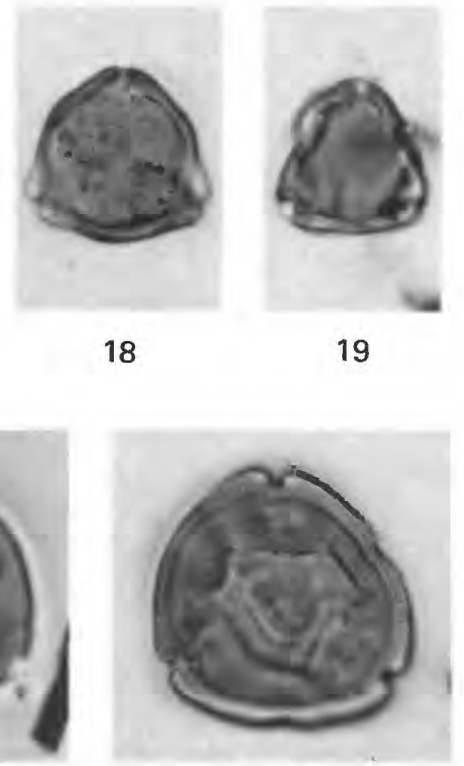

24

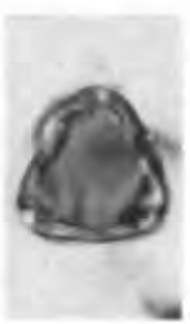

19

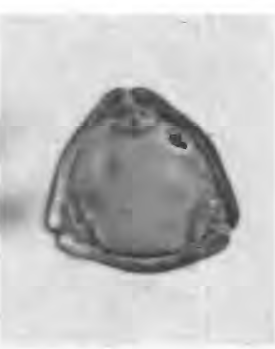

3

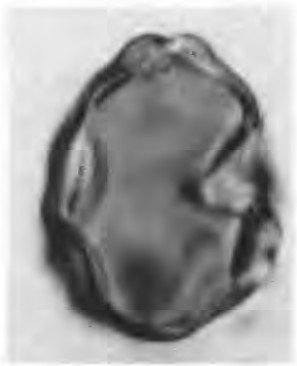

8

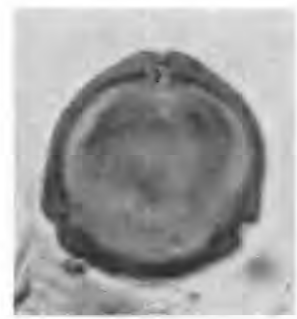

13

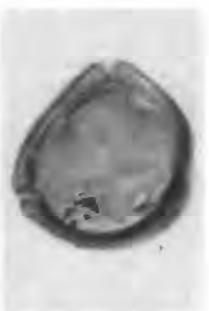

20

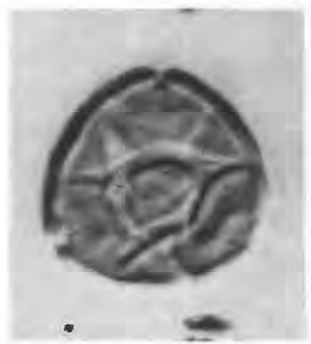

25

ANGIOSPERM POLLEN GRAINS

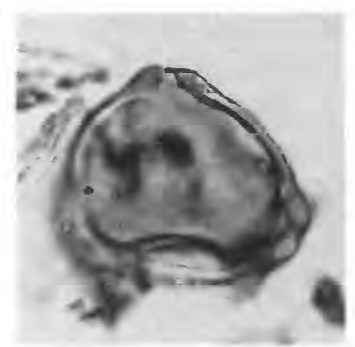

4

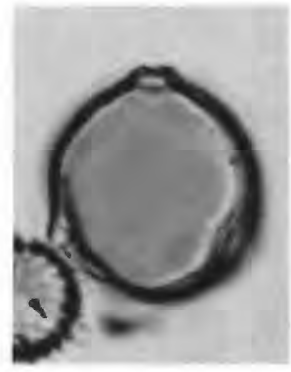

9

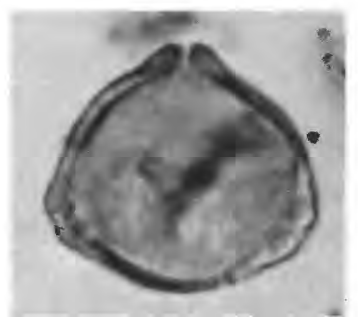

14

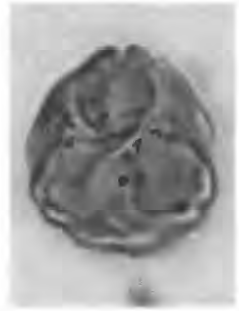

21

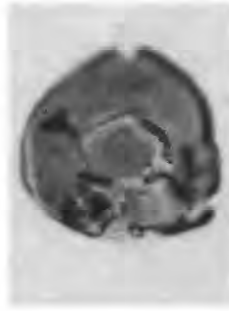

22

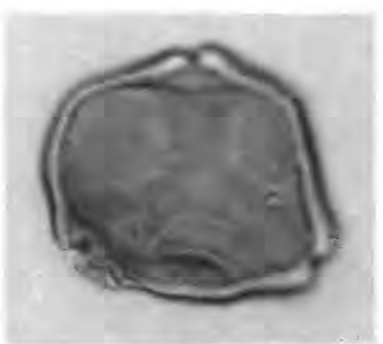

26
PLATE 2

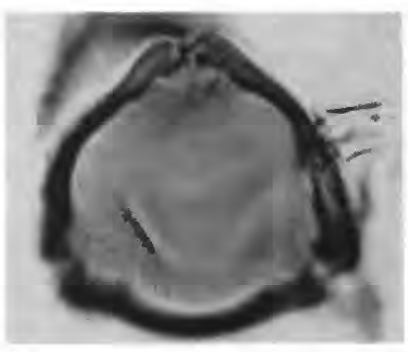

5

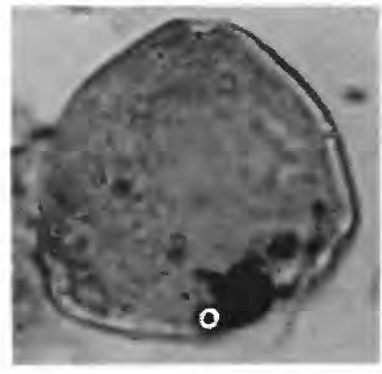

10

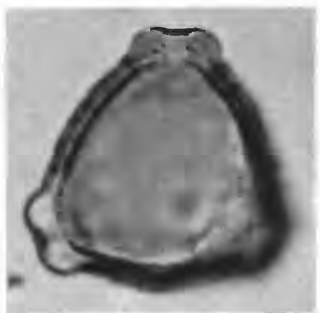

15

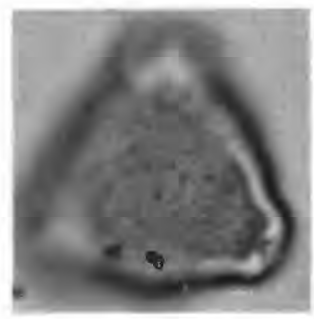

16

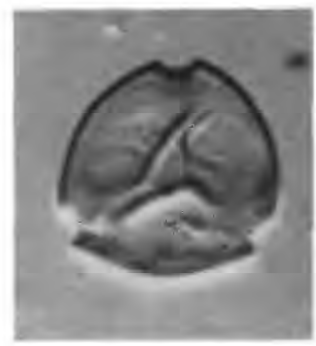

27 


\section{PLATE 3}

[Magnification $\times 1,000]$

Figures 1-4. Subtriporopollenites sp. Specimens of this species are more triangular than in S. nanus. Bashi Formation, eastern Alabama. 5, 6. Subtriporopollenites nanus (Pflug \& Thomson in Thomson \& Pflug 1953) Frederiksen 1980 (OTU 105). Hatchetigbee Formation, western Alabama.

7-11. Celtipollenites gracilis n. sp. (OTU 157). 7, 8, holotype. 7 -10, Lisbon Formation, western Alabama; 11, Albany core, western Georgia.

12-14. Celtis tschudyi group (triporate) (OTU 123). Lisbon Formation, western Alabama.

15. Celtis tschudyi group (multiporate) (OTU 159). Lisbon Formation, western Alabama.

16. Paraalnipollenites confusus (Zaklinskaya 1963) Hills \& Wallace 1969 (OTU 101). Basic City Shale Member, Tallahatta Formation, eastern Mississippi.

17, 18. Retitriporites sp. 18 , interference contrast. Albany core, western Georgia.

19, 20. Corsinipollenites sp. This specimen has a thinner annulus than C. oculus-noctis (Thiergart 1940) Nakoman 1965. Lisbon Formation, western Alabama.

21, 22. Retitriporites sp. Basic City Shale Member, Tallahatta Formation, eastern Mississippi.

23-26. Brosipollis striata n. sp. (OTU 133). 23-25, holotype, Tallahatta Formation, western Alabama; 26, Albany core, western Georgia. 
DEPARTMENT OF THE INTERIOR

U.S. GEOLOGICAL SURVEY

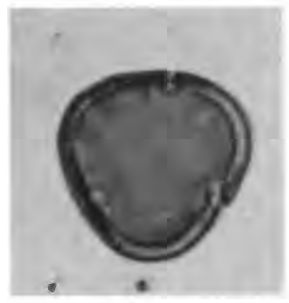

1

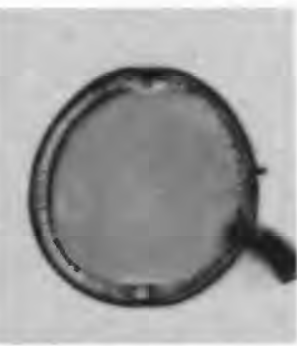

7

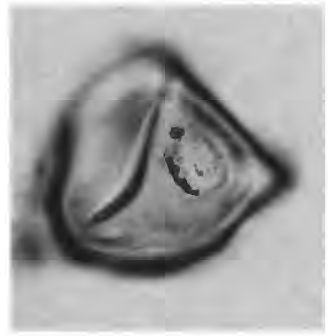

12

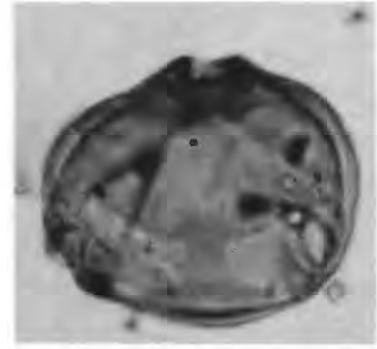

17

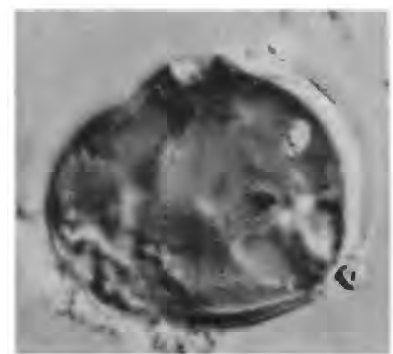

18

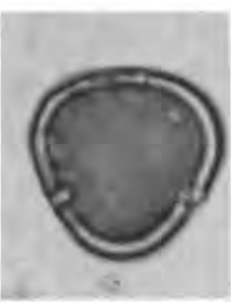

2

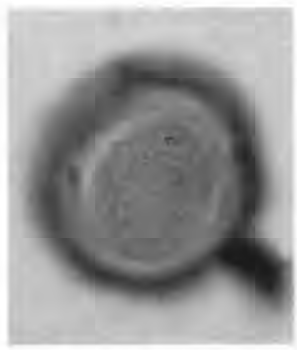

8

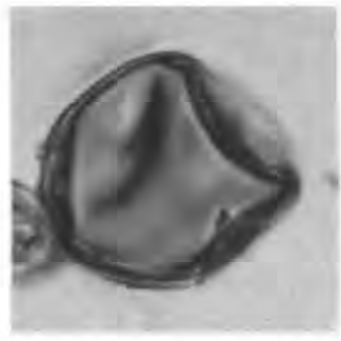

13

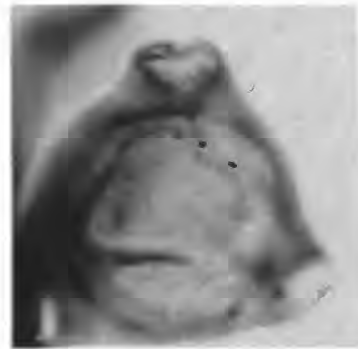

19

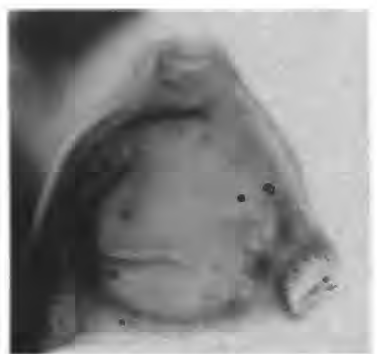

20

3
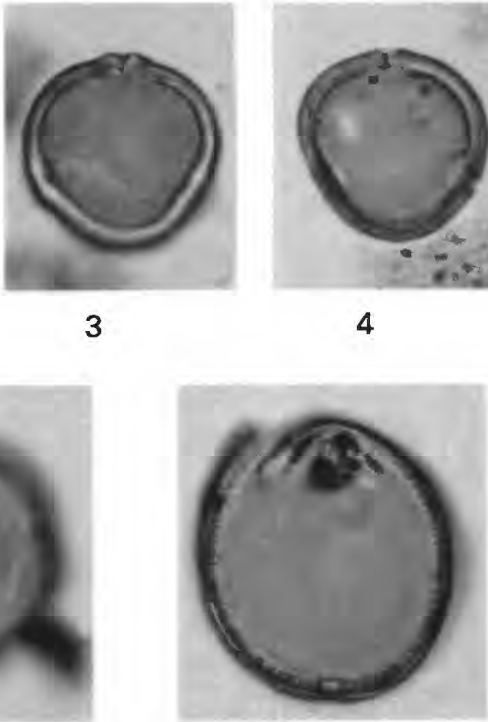

9

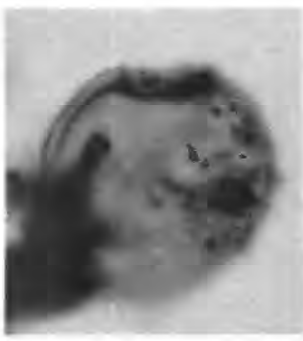

14

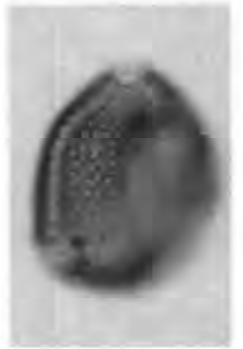

21

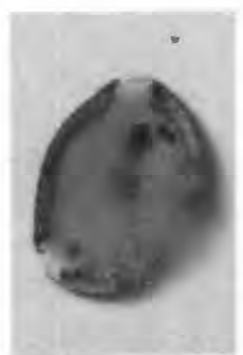

22

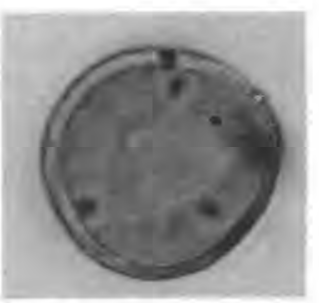

5

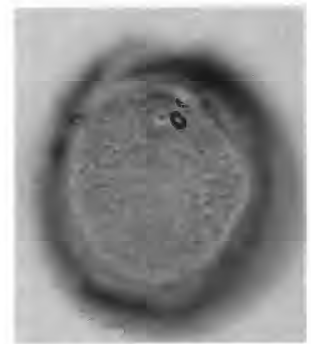

10

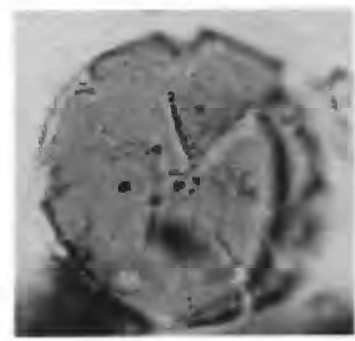

15

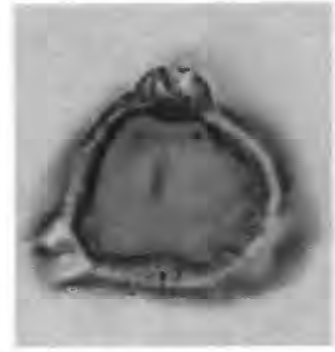

23

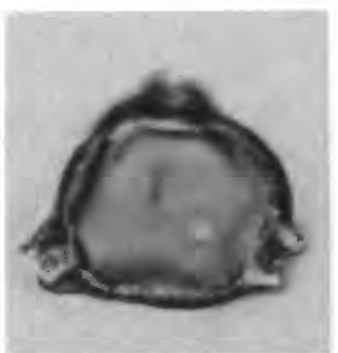

24
TROFESSIONAL PAPER 1448

PLATE 3

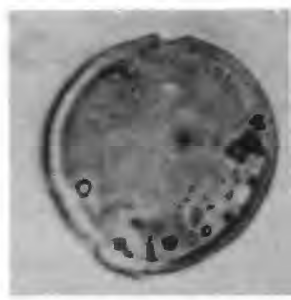

6

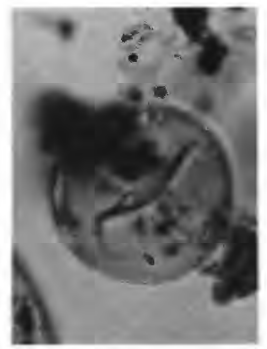

11

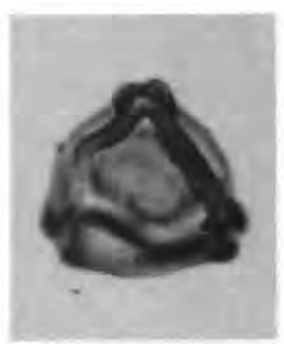

16

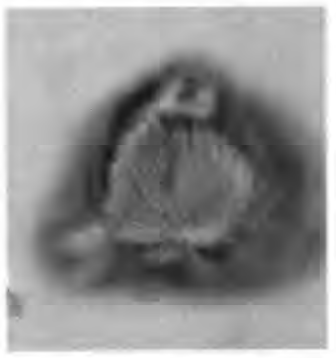

25

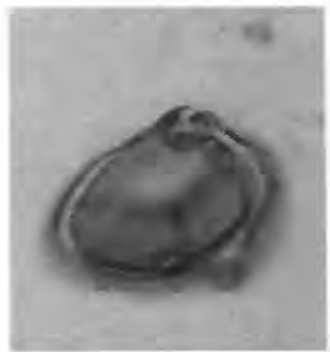

26 


\section{PLATE 4}

[Magnification $\times 1,000$ ]

Figures 1-3. Brosipollis striata n. sp. (OTU 133). 1, 2, Albany core, western Georgia; 3, Hatchetigbee Formation, eastern Alabama. 4-13. Brosipollis, other striate species (OTU 135). 4, Hatchetigbee Formation, eastern Alabama; 5, 6, Albany core, western Georgia; 7-9, Lisbon Formation, western Alabama; 10, 11, Hatchetigbee Formation, western Alabama; 12, 13, Cockfield or Cook Mountain Formation, western Mississippi.

14-16. Corsinipollenites? verrucatus n. sp. (OTU 129). 14, 15, Hatchetigbee Formation, eastern Alabama; 16, Albany core, western Georgia.

17-25. Echitriporites spp. 17-21, Albany core, western Georgia; 22-25, Lisbon Formation, western Alabama. 


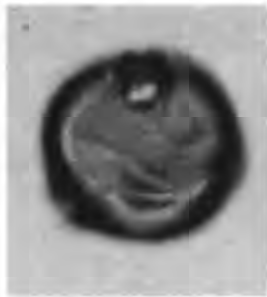

1

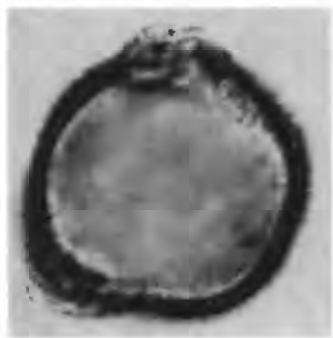

7

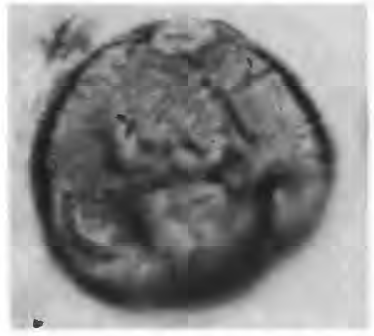

12

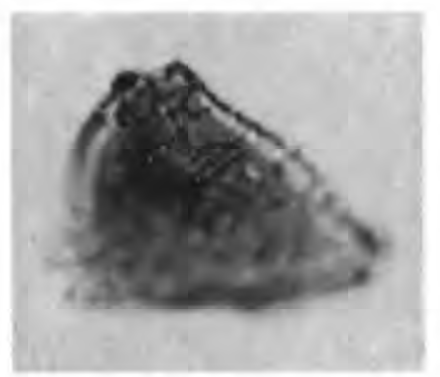

17

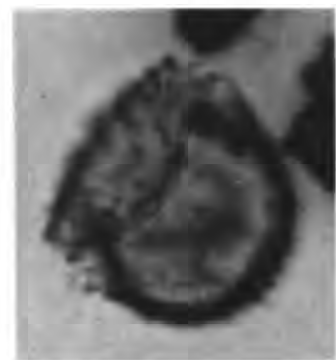

22

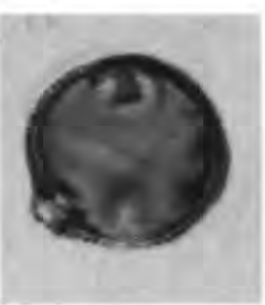

2

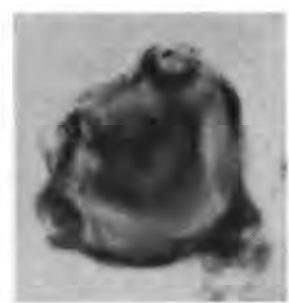

3

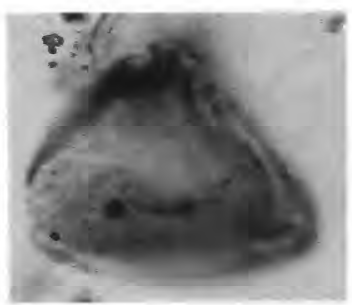

4

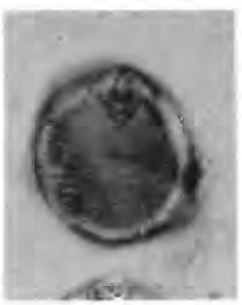

5

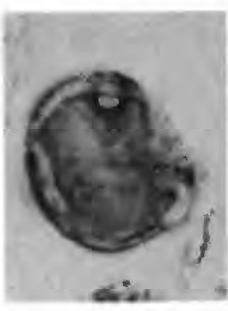

6

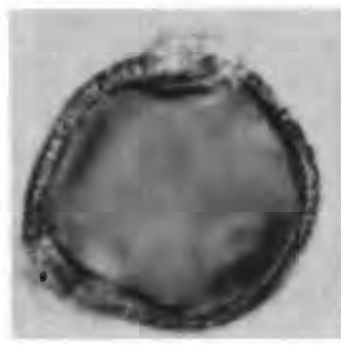

8

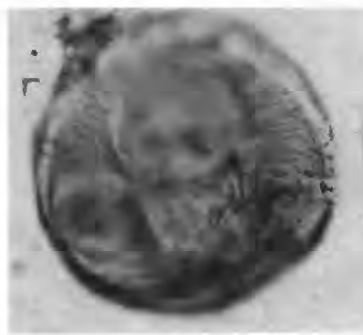

13

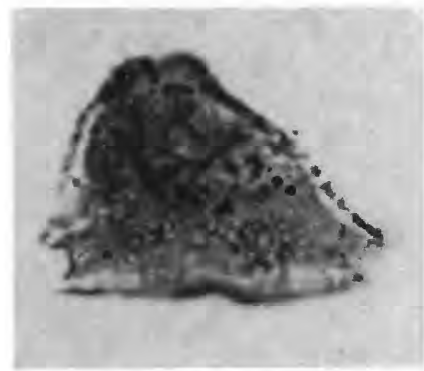

18

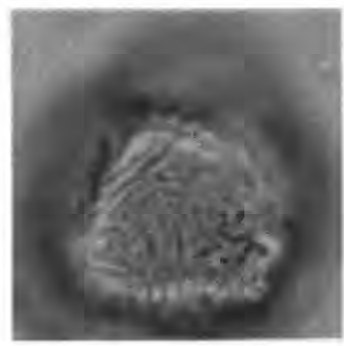

9

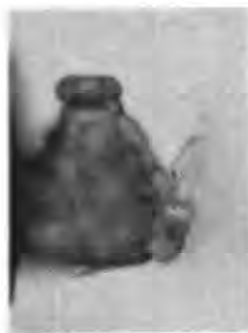

14

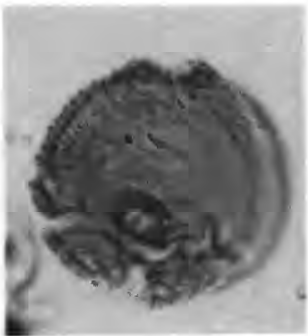

10

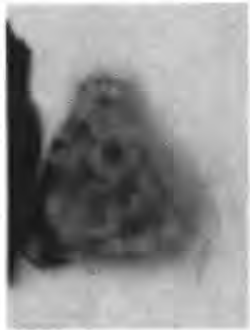

15

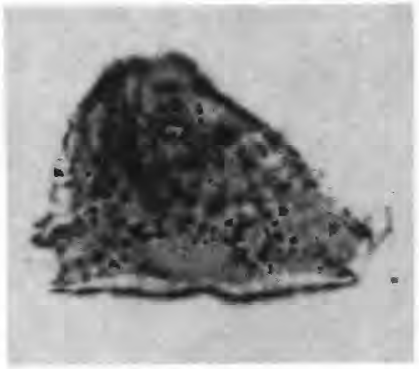

19

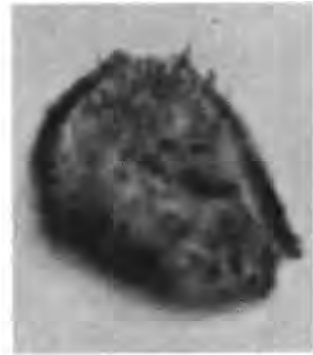

25

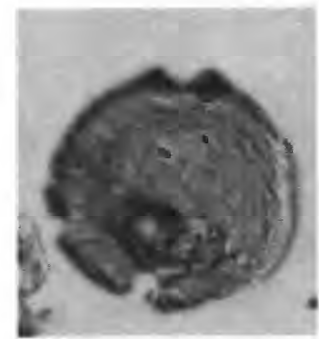

11

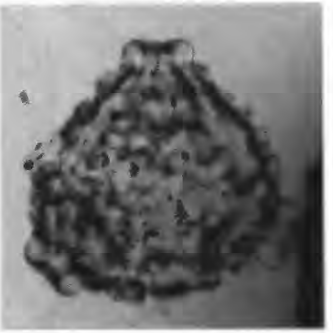

16

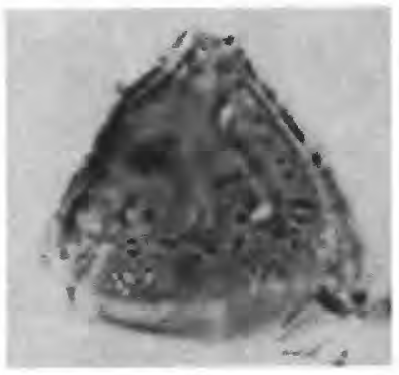

20

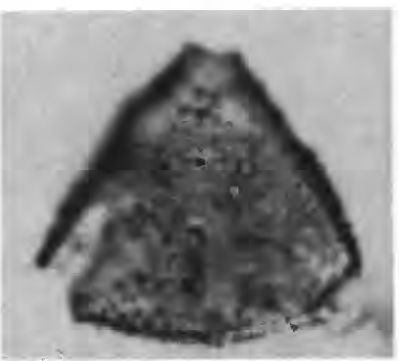

21 


\section{PLATE 5}

[Magnification $\times 1,000]$

Figures 1, 2. Echitriporites sp. Lisbon Formation, western Alabama.

3, 4. Anacolosidites reklawensis Elsik 1974 (OTU 141). Tallahatta Formation, eastern Alabama.

5. Anacolosidites claibornensis Elsik 1974 (OTU 139). Basic City Shale Member, Tallahatta Formation, eastern Mississippi.

6-8. Anacolosidites sp. 1 (OTU 143). Interference contrast; Lisbon Formation, western Alabama.

9. Malvacipollis tschudyi (Frederiksen 1973) Frederiksen 1980 (OTU 147). Albany core, western Georgia.

10-14. Malvacipollis cf. M. tschudyi (OTU 149). In these specimens, the coni are thicker than in $M$. tschudyi. 11, 14, interference contrast. Albany core, western Georgia.

15-19. Reevesiapollis spp. (OTU 151). 16, interference contrast. 15, 16, Tallahatta Formation, western Alabama; 17-19, Lisbon Formation, western Alabama.

20-23. Longapertites spp. (OTU 177). 20, 21, Lisbon Formation, western Alabama; 22, 23, Hatchetigbee Formation, western Alabama. 
DEPARTMENT OF THE INTERIOR

U.S. GEOLOGICAL SURVEY

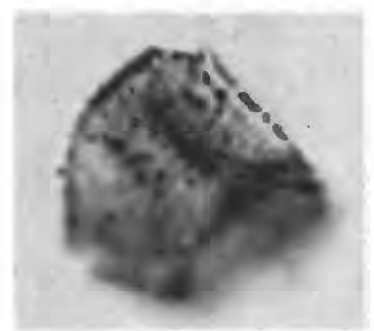

1

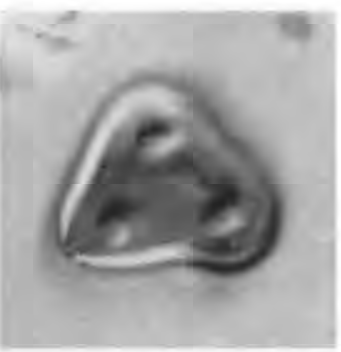

6

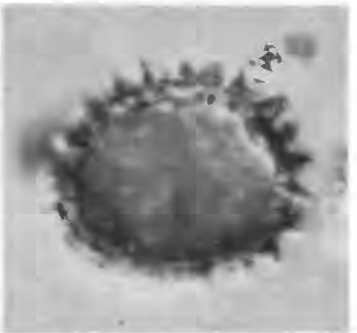

11

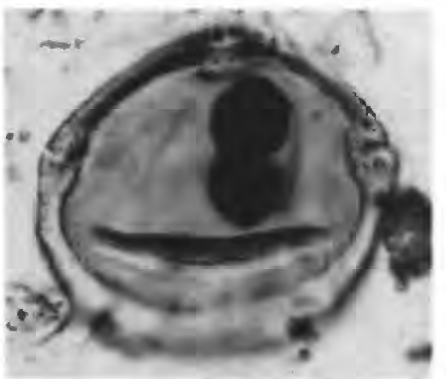

17

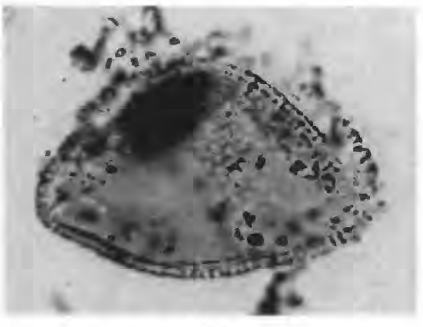

20

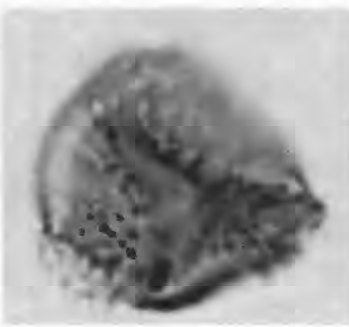

2

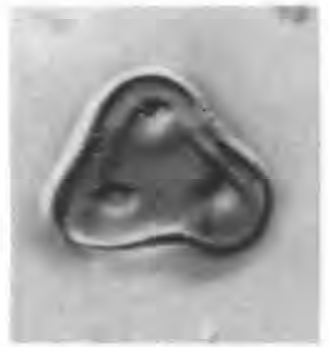

7

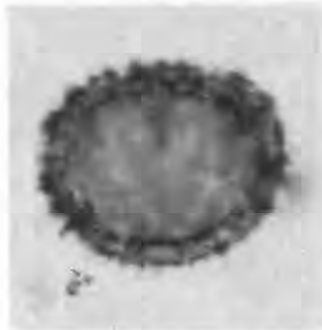

12

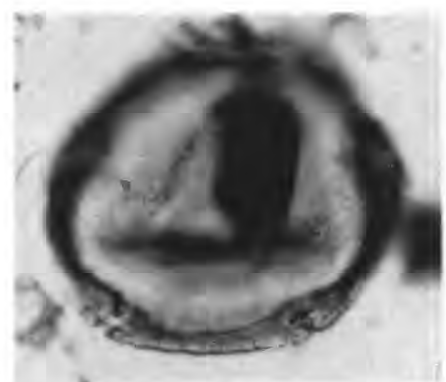

18

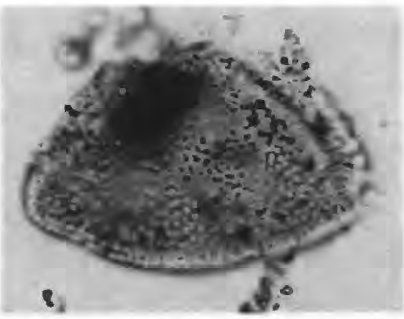

21

ANGIOSPERM POLLEN GRAINS

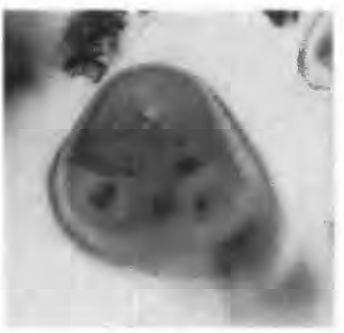

3

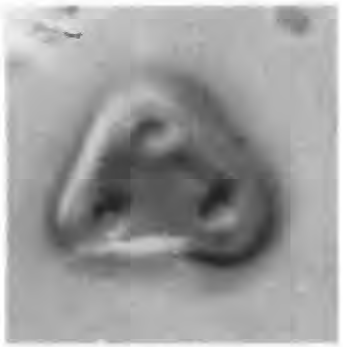

8

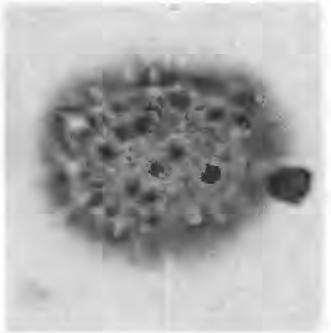

13

PROFESSIONAL PAPER 1448

PLATE 5

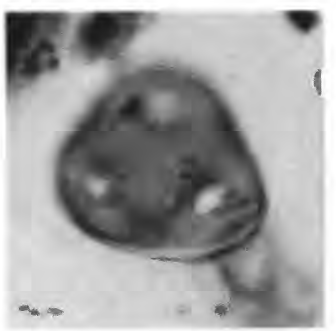

4

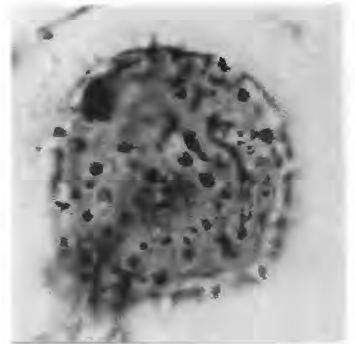

9

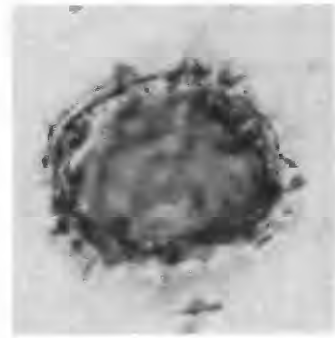

14

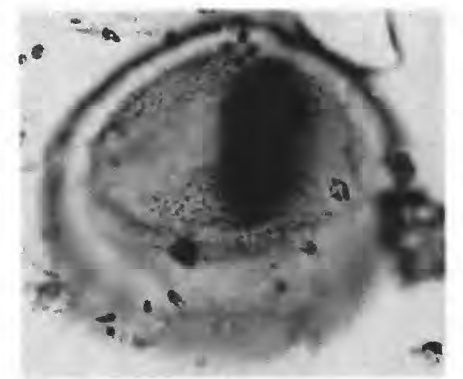

19

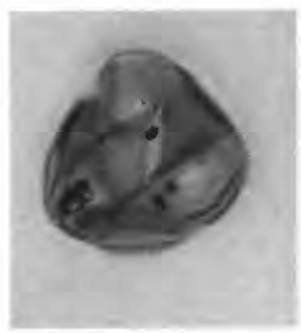

5

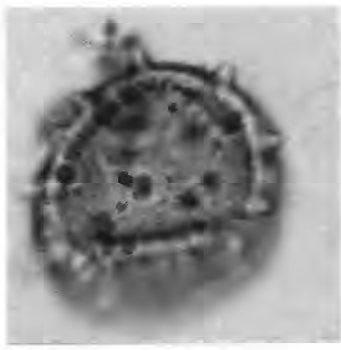

10

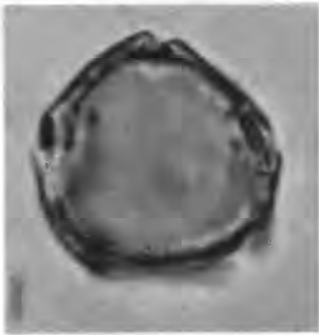

15

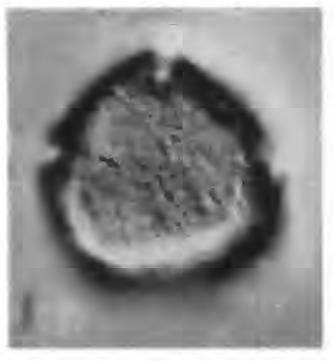

16

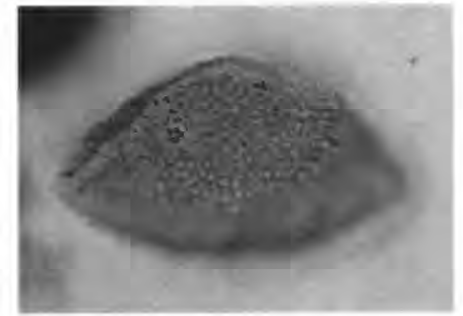

22

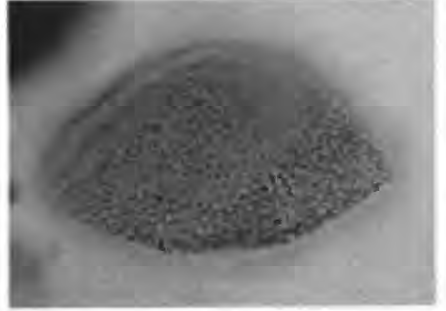

23 


\title{
PLATE 6
}

\author{
[Magnification $\times 1,000]$
}

Figures 1, 2. Longapertites sp. (OTU 177). This specimen is punctate. Lisbon Formation, western Alabama.

3-11. Proxapertites spp. (OTU 179). 3-5, Tallahatta Formation, western Alabama; 6, 7, Basic City Shale Member, Tallahatta Formation, eastern Mississippi; 8-11, Bashi Formation, eastern Alabama.

12-19. Dicolpopollis spp. (OTU 183). 12-15, 19, interference contrast. 12, 13, Dobys Bluff Tongue (Dockery, 1980), Kosciusko Formation (of Thomas, 1942), eastern Mississippi; 14, 15, Hatchetigbee Formation, western Alabama; 16, 17, Albany core, western Georgia; 18, 19, Bashi Formation, eastern Alabama. 


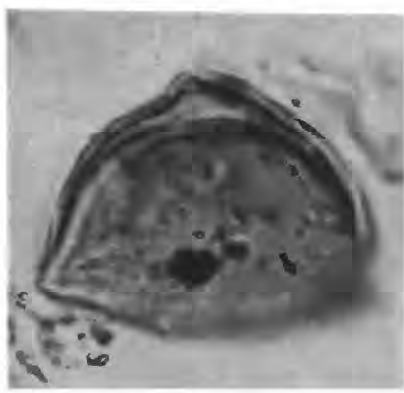

1

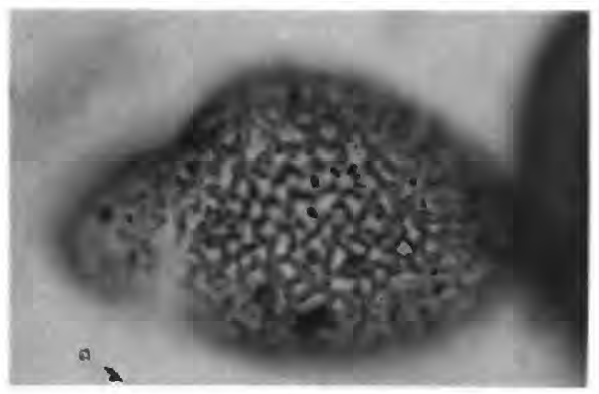

6

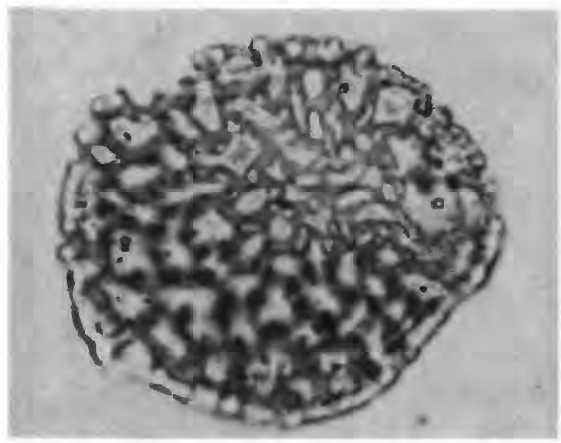

8

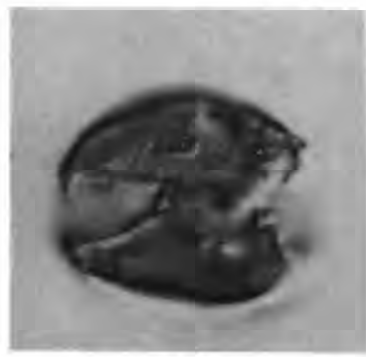

12

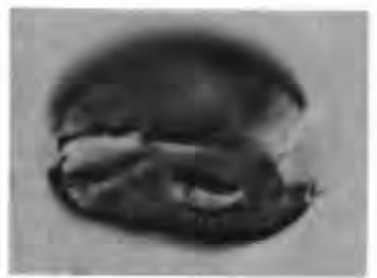

13

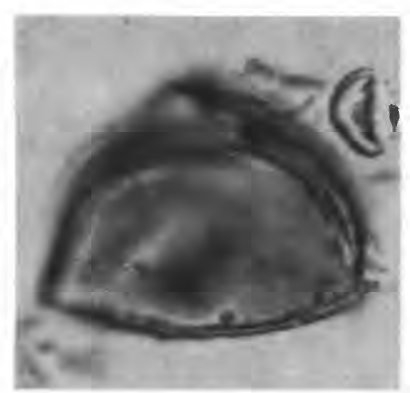

2

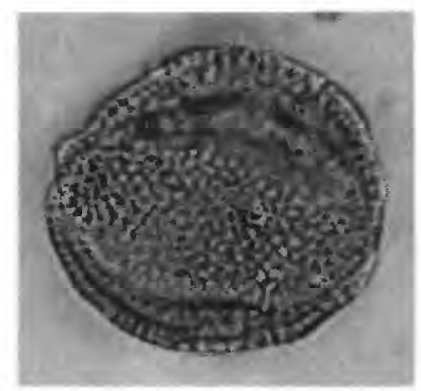

3

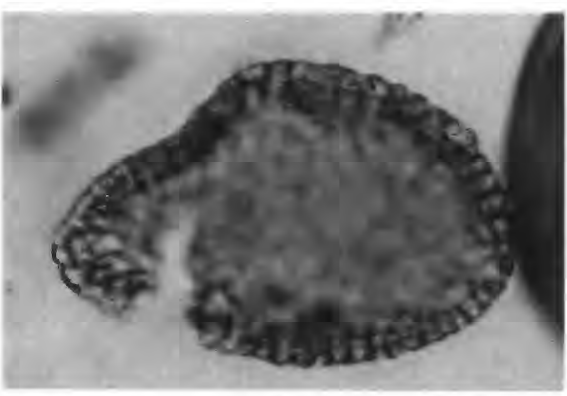

7

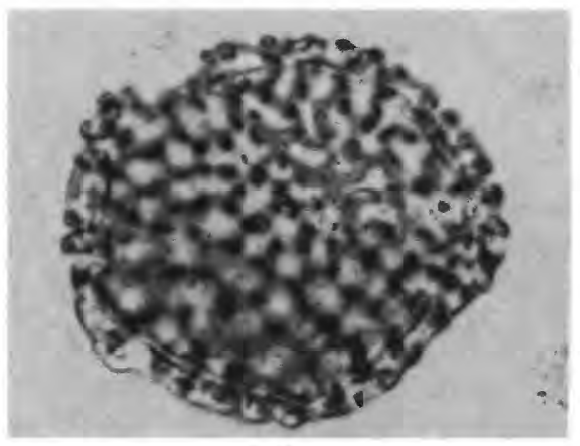

9

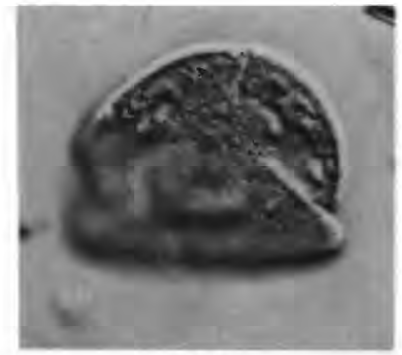

14

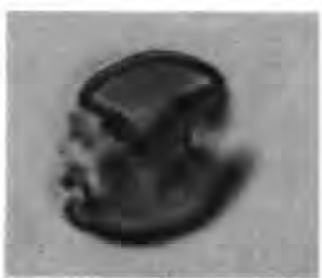

16

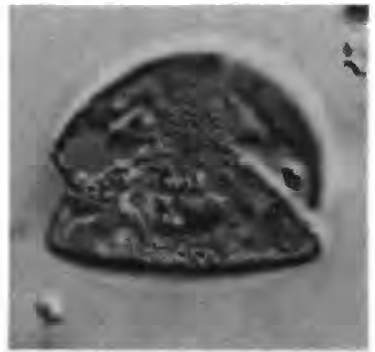

15

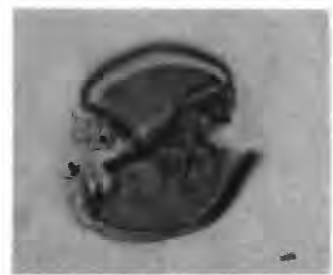

17

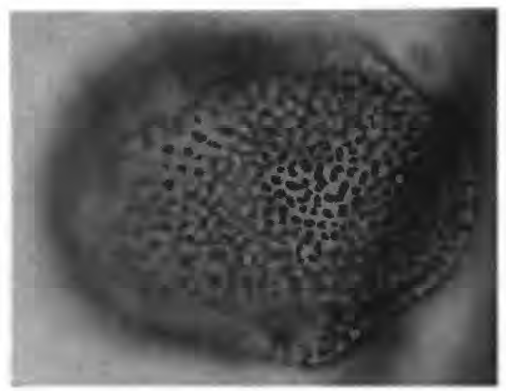

4

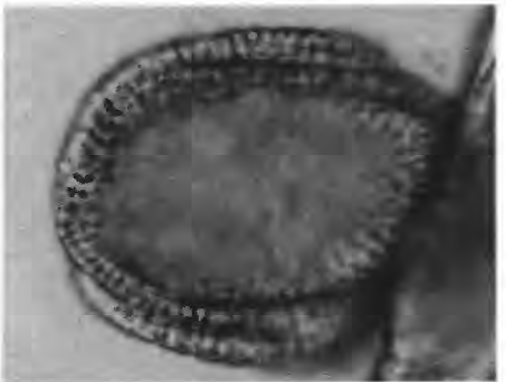

5

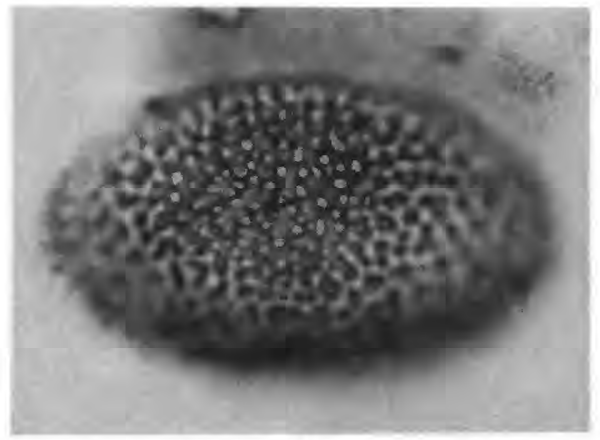

10

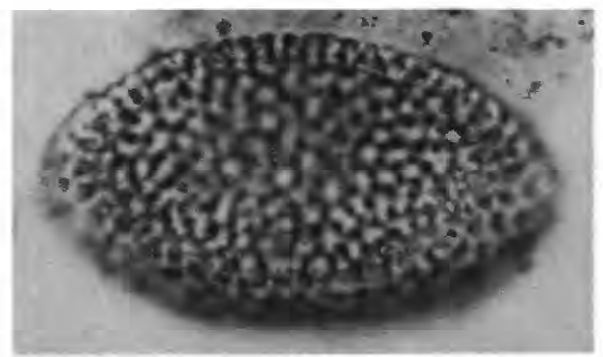

11

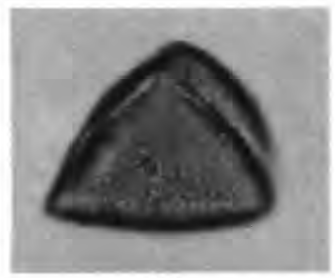

18

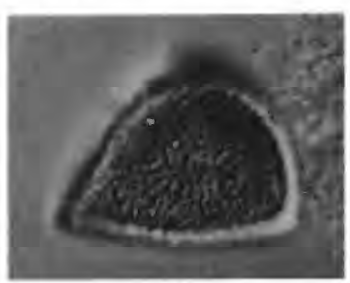

19

ANGIOSPERM POLLEN GRAINS 


\section{PLATE 7}

[Magnification $\times 1,000$ ]

FIGURE 1. Eucommia type (tricolpate) (OTU 185). Lisbon Formation, western Alabama.

2-10. Retibrevitricolpites simplex n. sp. (OTU 207). 2, 3, holotype. 2-5, Lisbon Formation, western Alabama; 6-10, Zilpha Clay, western Mississippi.

11, 12. Tricolpites reticulatus Couper 1953 (OTU 201). 12, interference contrast. Albany core, western Georgia.

13-15. Tricolpites interangulus Newman 1965 (OTU 199). Note thickened colpi margines at the equator, which are lacking in $T$. reticulatus. T. interangulus is very similar to Aesculiidites circumstriatus (Fairchild in Stover et al. 1966) Elsik 1968 except that its lumina are not arranged in circumpolar circles as they are in A. circumstriatus. 14, interference contrast. Albany core, western Georgia.

16. Enopadios reticulatus Elsik \& Dilcher 1974 (OTU 209). Lisbon Formation, western Alabama.

17, 18. Retibrevitricolpites sp. Interference contrast; Lisbon Formation, western Alabama.

19, 20. Polycolpites sp. Lisbon Formation, western Alabama. 
DEPARTMENT OF THE INTERIOR

U.S. GEOLOGICAL SURVEY

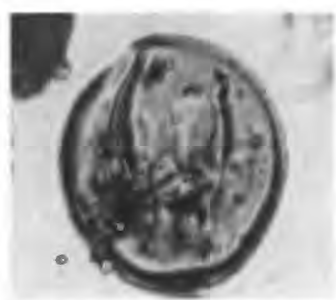

1

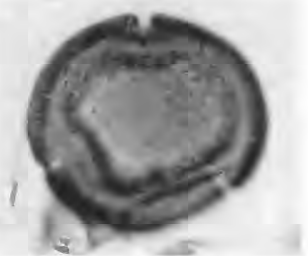

6

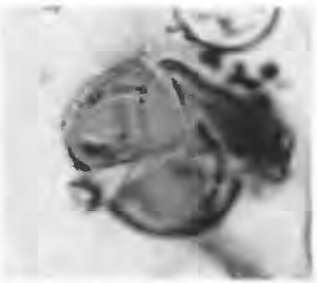

11

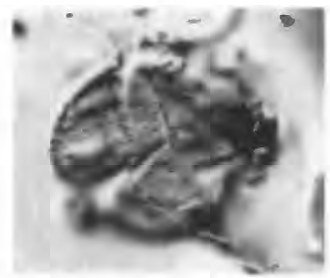

12

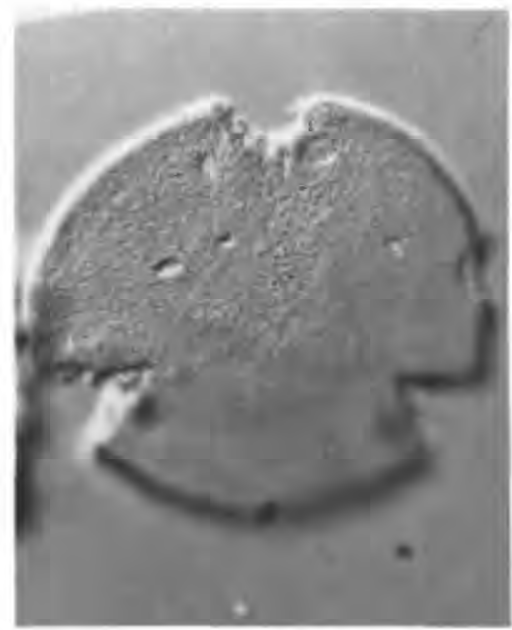

17

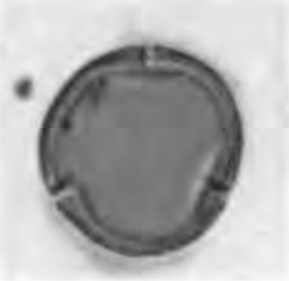

2

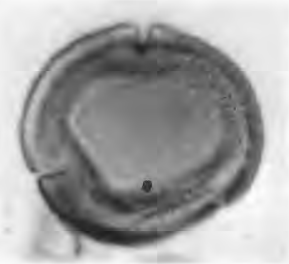

7

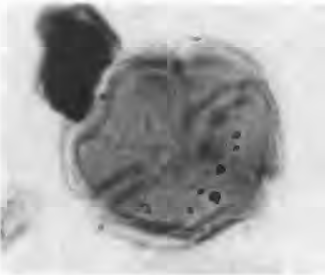

13

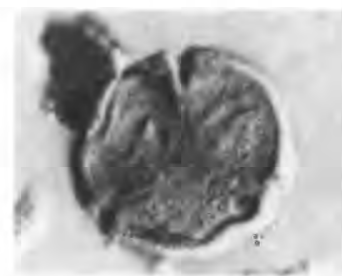

14

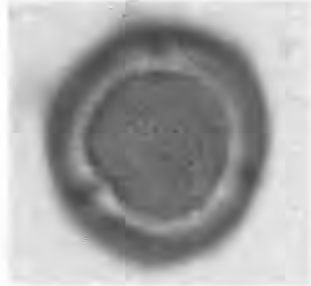

3

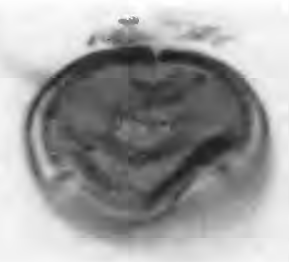

8

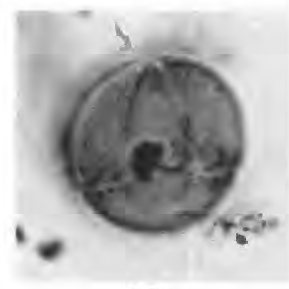

15

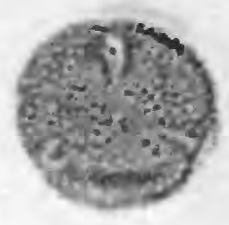

16

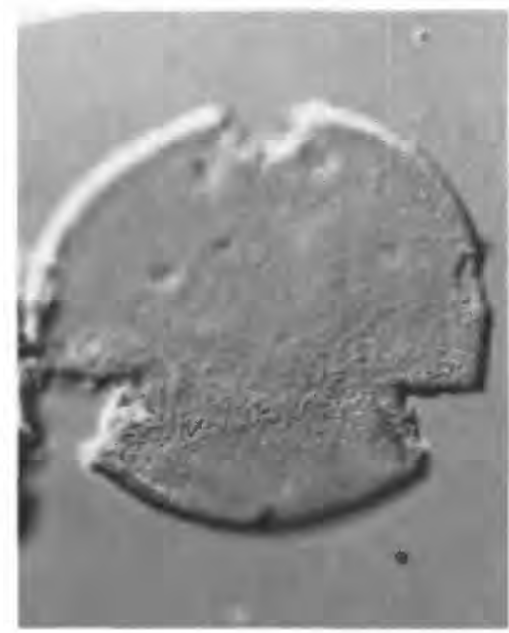

18

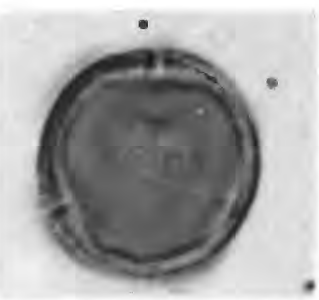

4

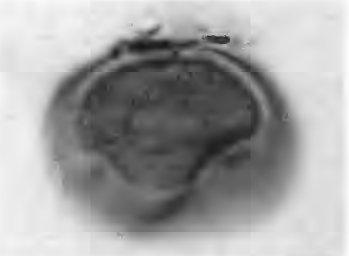

9

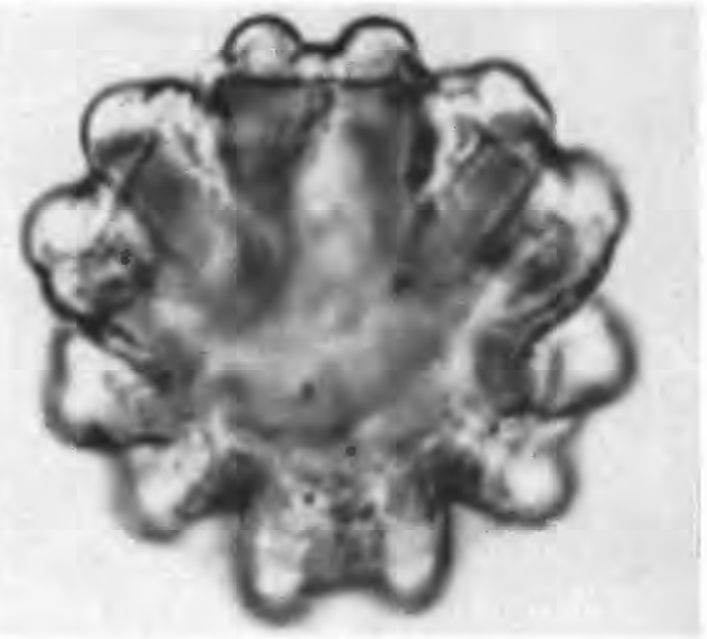

19

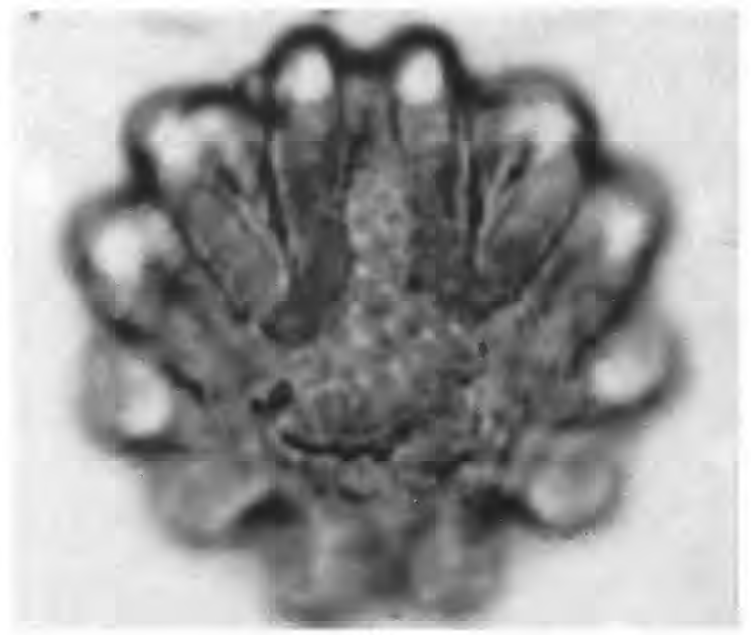

20

\section{PROFESSIONAL PAPER 1448 \\ PLATE 7}

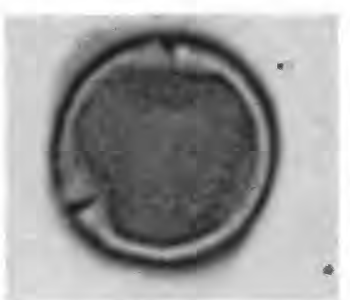

5

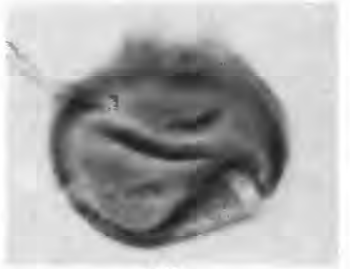

10 


\section{PLATE 8}

[Magnification $\times 1,000$ ]

FigurEs 1-5. Eucommia type (tricolporate) (OTU 213). Compare with the tricolpate type in plate 7, figure 1. 1-3, Lisbon Formation, western Alabama; 4, Albany core, western Georgia; 5, Cockfield or Cook Mountain Formation, western Mississippi.

6, 7. Cyrillaceaepollenites megaexactus (Potonié 1931) Potonié 1960 (OTU 217). Zilpha Clay, western Mississippi.

8, 9. Cyrillaceaepollenites barghoornianus (Traverse 1955) Potonié 1960 (OTU 219). Compare thickness of exine with that of C. megaexactus. 8, Albany core, western Georgia; 9, Tallahatta Formation, eastern Alabama.

10-15. Tetracolporopollenites prolatus n. sp. (OTU 225). 10, 11, holotype. Like T. megadolium (Potonié 1934) Frederiksen 1980, this species is tricolporate. 10-12, 15, Zilpha Clay, western Mississippi; 13, 14, Basic City Shale Member, Tallahatta Formation, eastern Mississippi.

16. Tetracolporopollenites megadolium type (short colpi) (OTU 221). Zilpha Clay, western Mississippi.

17, 18. Tetracolporopollenites megadolium type (long colpi) (OTU 223). Lisbon Formation, western Alabama.

19-22. Siltaria abouziarovae group (OTU 229). Lisbon Formation, western Alabama.

23-26. Porocolpopollenites sp. 1 (OTU 293). 23, 24, Albany core, western Georgia; 25, 26, Hatchetigbee Formation, western Alabama.

27, 28. Syncolporites sp. 2 (OTU 269). Hatchetigbee Formation, eastern Alabama. 
DEPARTMENT OF THE INTERIOR

U.S. GEOLOGICAL SURVEY

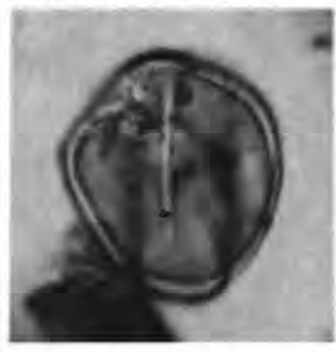

1

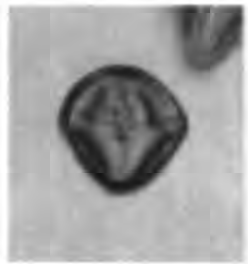

6

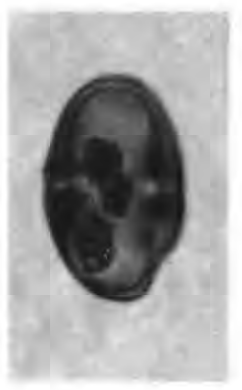

13

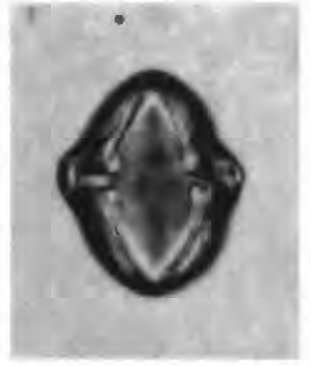

19

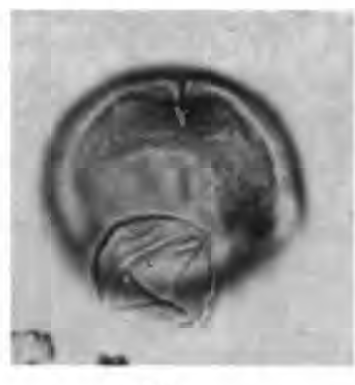

23

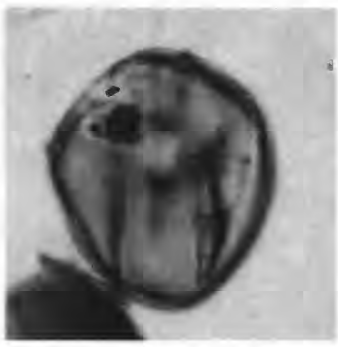

.

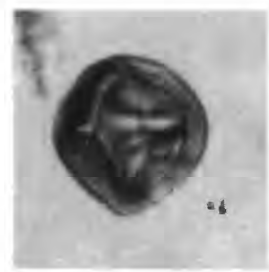

8

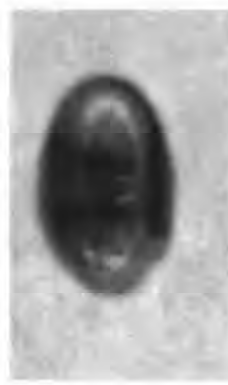

14

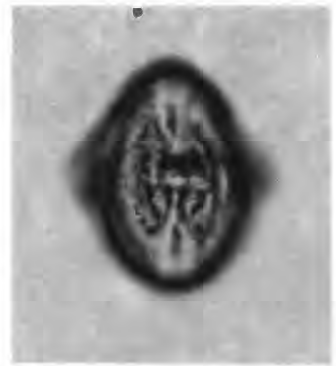

20

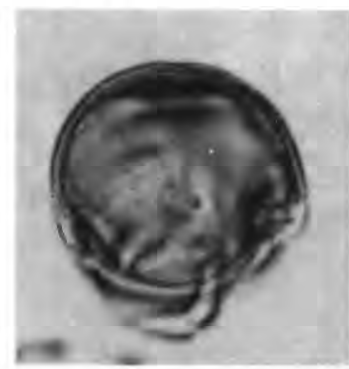

24

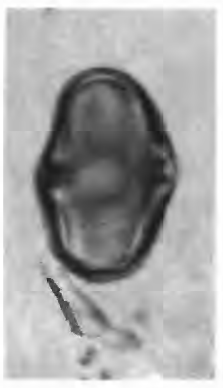

15

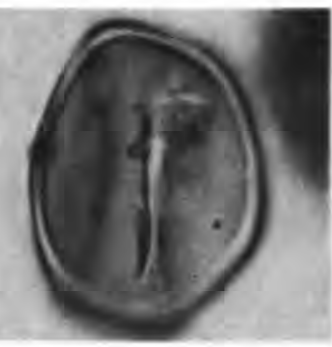

3

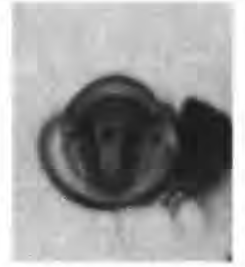

9

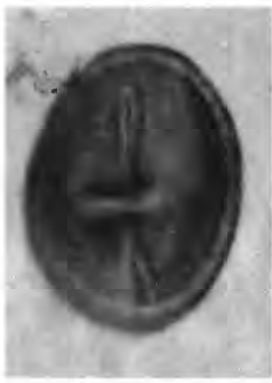

16

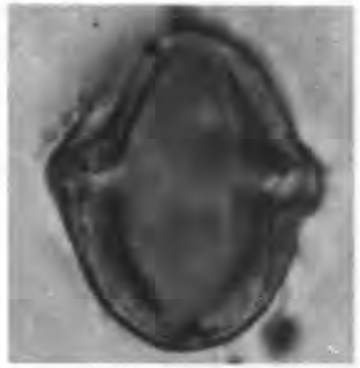

21

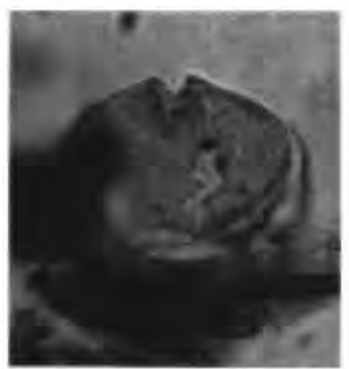

25

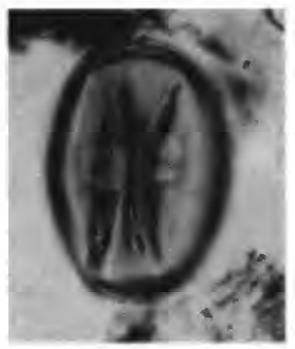

4
PROFESSIONAL PAPER 1448

PLATE 8

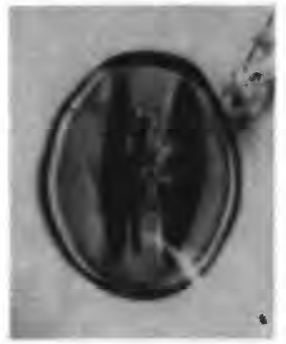

5
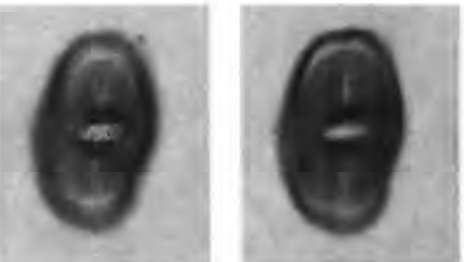

11

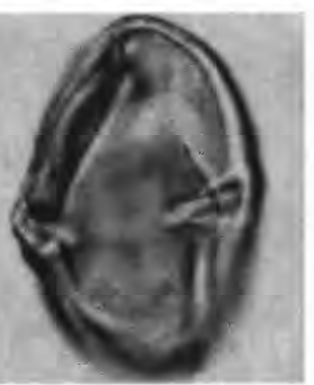

17

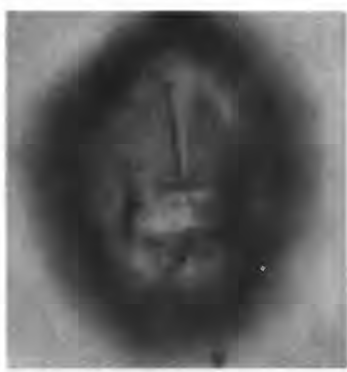

22

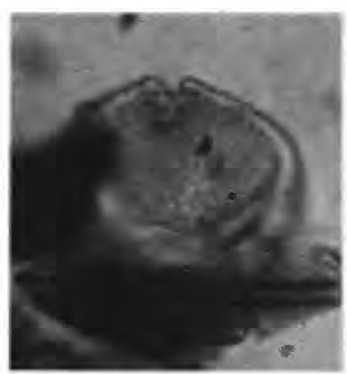

26

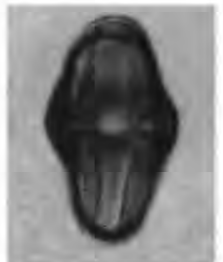

12

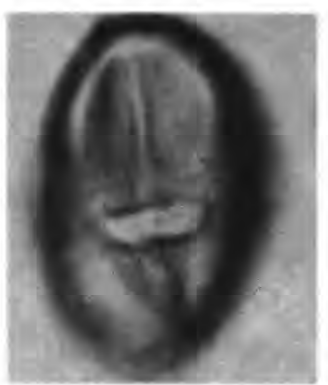

18

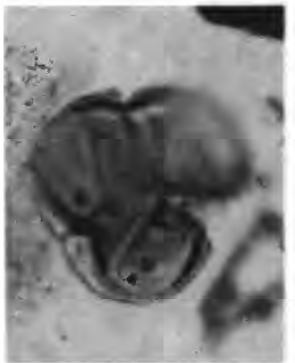

27

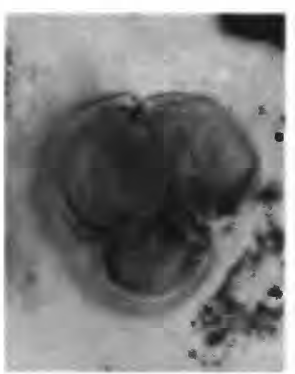

28 


\section{PLATE 9}

[Magnification $\times 1,000]$

FIGURES 1-4. Syncolporites sp. 2 (OTU 269). 2, interference contrast. 1, 2, Dobys Bluff Tongue (Dockery, 1980), Kosciusko Formation (of Thomas, 1942), eastern Mississippi; 3, 4, Lisbon Formation, western Alabama.

5, 6. Symplocos? cf. Symplocos sp. of Frederiksen (1980c, pl. 15, fig. 22). In this group of species, the grains are psilate or indistinctly punctate. 5, Lisbon Formation, western Alabama; 6, Tallahatta Formation, eastern Alabama.

7, 8. Symplocos? virginiensis group (OTU 287). 7, Albany core, western Georgia; 8, Tallahatta Formation, western Alabama.

9-11. Symplocos? vestibulum (Potonié 1934) Frederiksen 1980 (OTU 285). 9, 10, Basic City Shale Member, Tallahatta Formation, eastern Mississippi; 11, Tallahatta Formation, western Alabama.

12. Symplocos? cf. S.? jacksoniana Traverse 1955. Zilpha Clay, western Mississippi.

13-19. Symplocos? sp. 1 (OTU 289). 13-15, 18, 19, Albany core, western Georgia; 16, 17, Lisbon Formation, western Alabama.

20-23. Syncolporites? sp. 1 (OTU 267). 20, 21, Lisbon Formation, western Alabama; 22, 23, Albany core, western Georgia (interference contrast). 

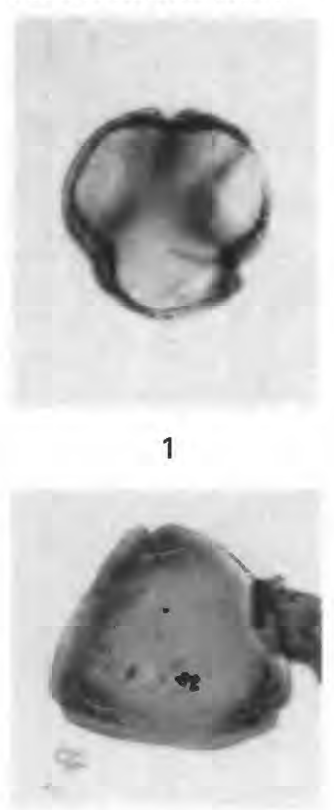

6

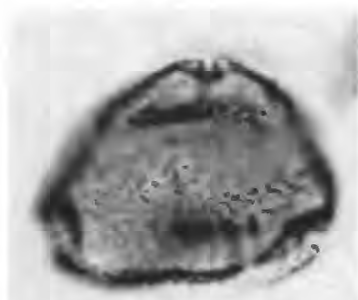

11

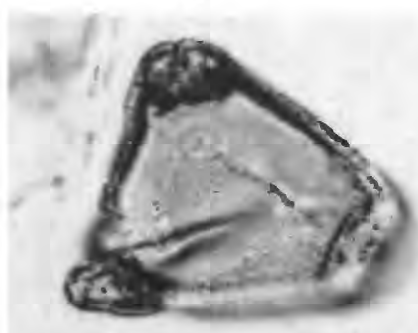

16

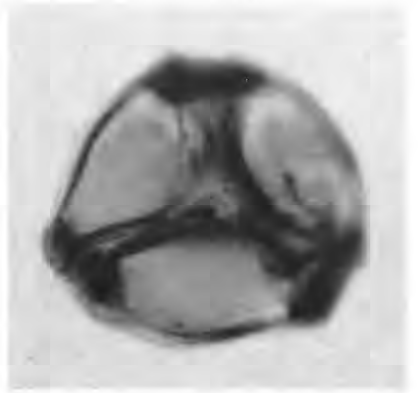

20

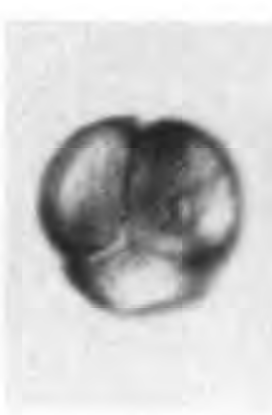

2

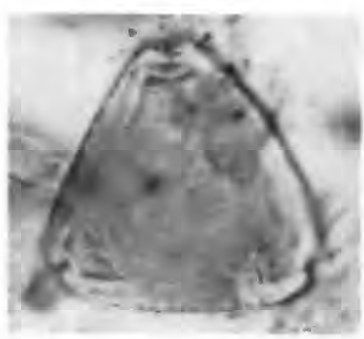

7

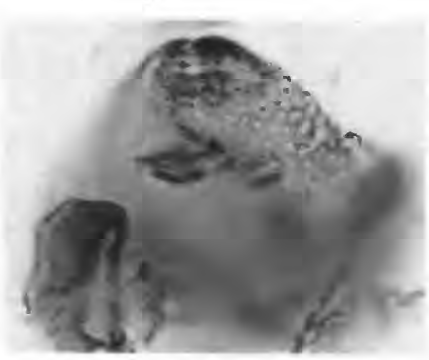

12

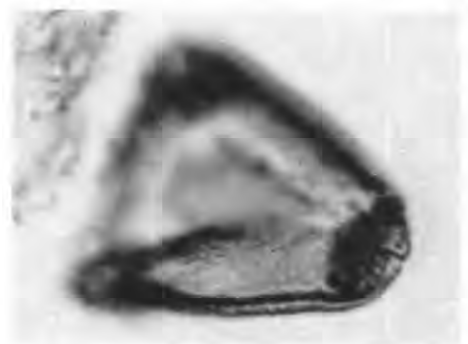

17

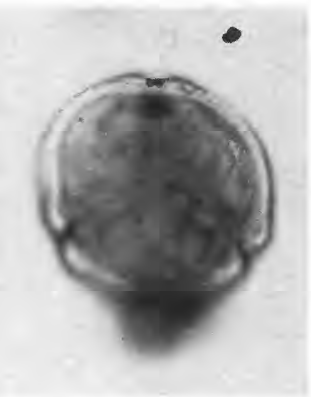

4

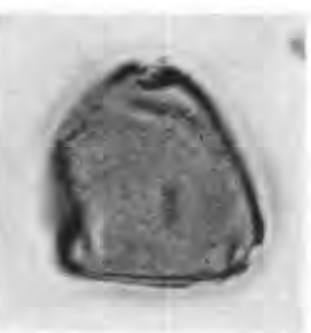

8

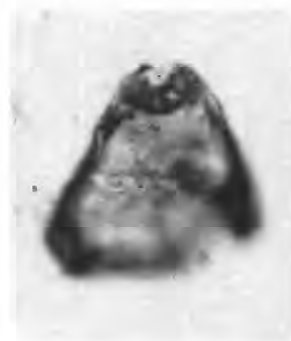

13

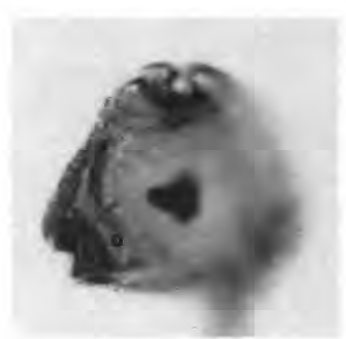

9

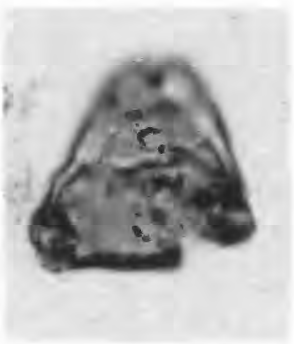

14

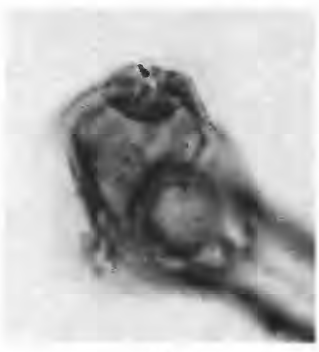

18

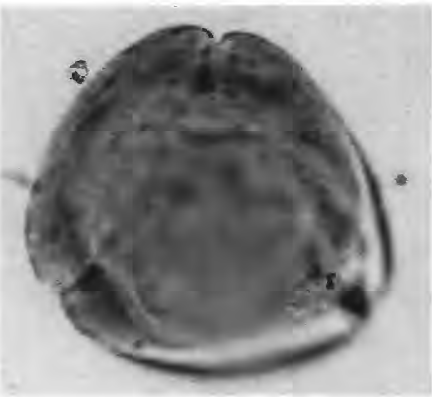

5

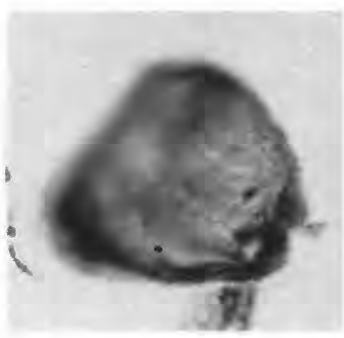

10

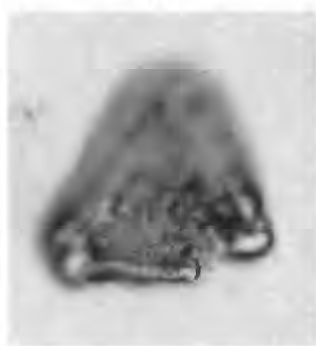

15

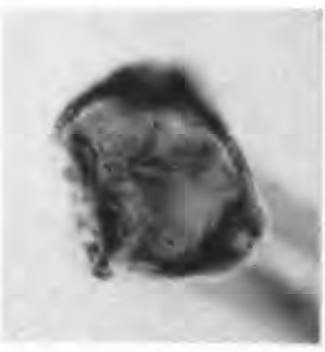

19

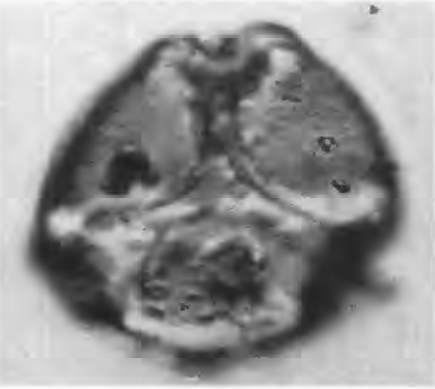

22

ANGIOSPERM POLLEN GRAINS

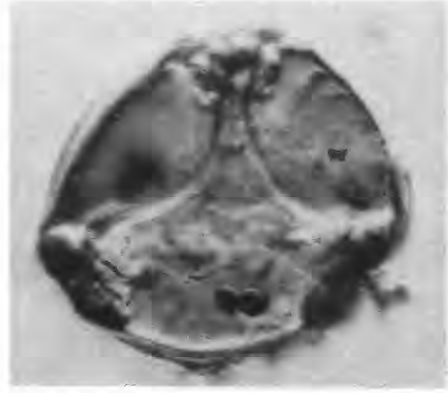

23 


\title{
PLATE 10
}

\author{
[Magnification $\times 1,000$
}

FIGURES 1-4. Syncolporites? sp. 1 (OTU 267). 2, 3, interference contrast. 1-3, Albany core, western Georgia; 4, Lisbon Formation, western Alabama.

5-8. Syncolporites tenuis Chateauneuf 1980 (OTU 265). 6-8, interference contrast. 7, 8, opposite faces of one specimen showing that it is syncolpate on both sides. 5-8, Tallahatta Formation, western Alabama.

9, 10. Boehlensipollis verrucata n. sp. (OTU 263). Lisbon Formation, western Alabama.

11-13. Boehlensipollis aff. B. granulata Frederiksen 1983. In this specimen, the colpi on both faces are indistinct; they appear to be syncolpate on one face and nearly so on the other face. 13, interference contrast. Albany core, western Georgia.

14-16. Ilexpollenites auriculoides Elsik 1974 (OTU 241). Compare the large clavae at the ends of the grain $(14,15)$ with the very small ones along the sides (16). 14-16, Lisbon Formation, western Alabama.

17, 18. Gothanipollis redactus Elsik 1974 (OTU 273). Lisbon Formation, western Alabama.

19-24. Nyssapollenites spp. 19-23, Basic City Shale Member, Tallahatta Formation, eastern Mississippi; 24, Hatchetigbee Formation, western Alabama. 
DEPARTMENT OF THE INTERIOR

U.S. GEOLOGICAL SURVEY

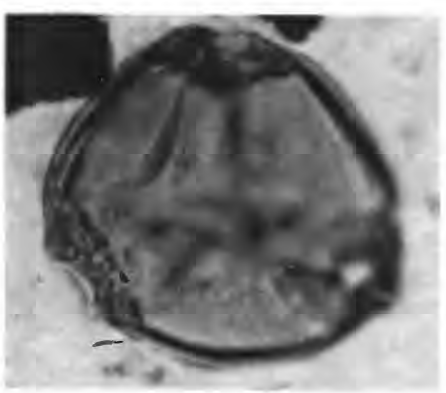

1

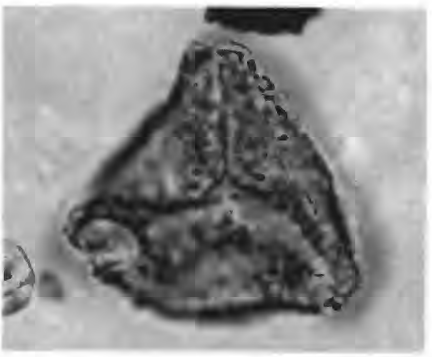

5

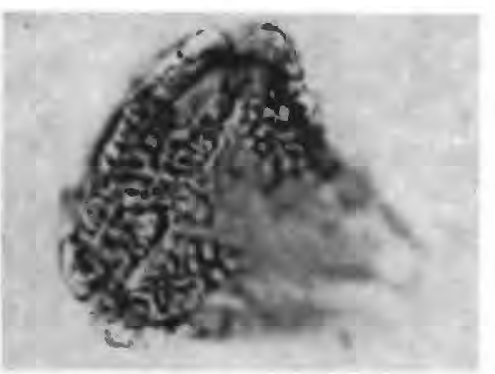

9

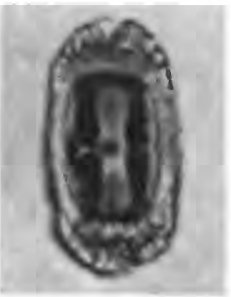

14

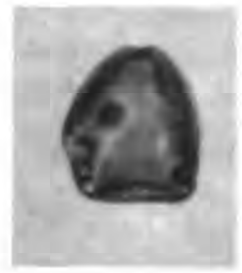

19

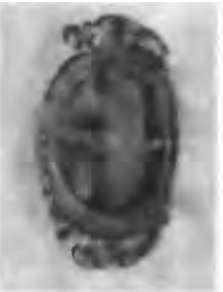

15

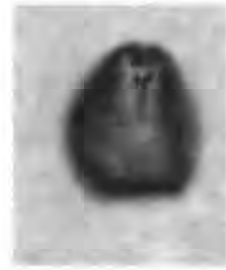

20

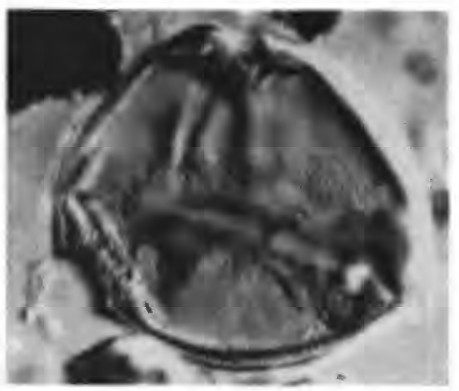

2

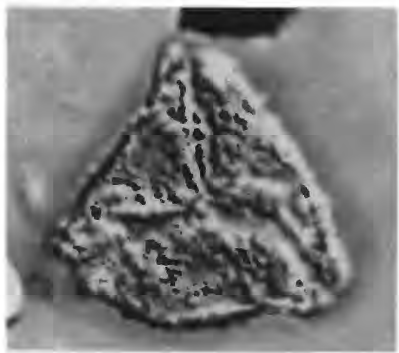

6

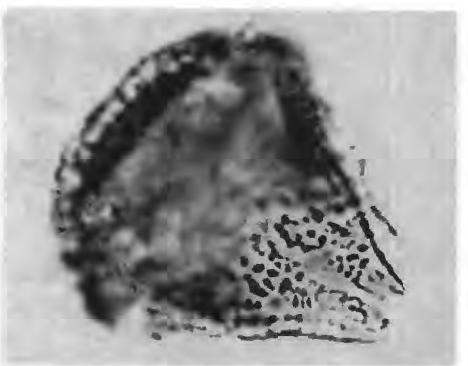

10

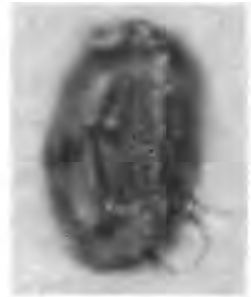

16

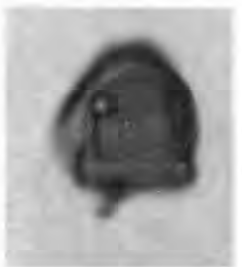

21

22

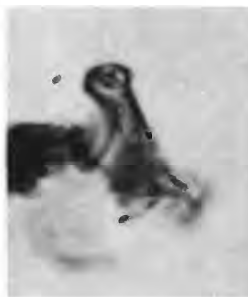

17
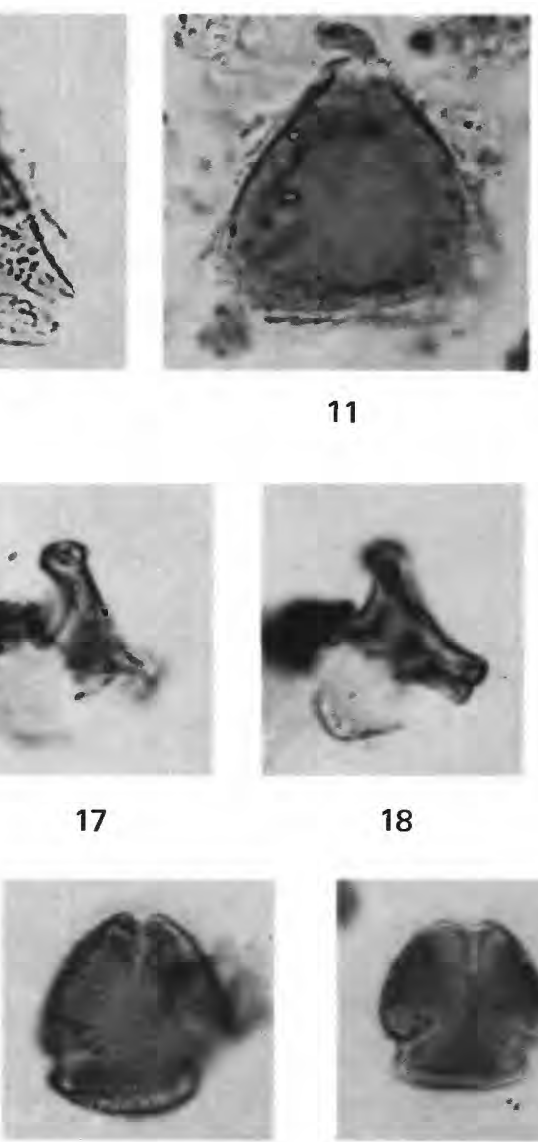

11

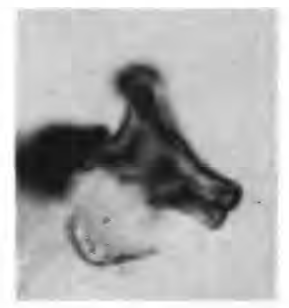

18

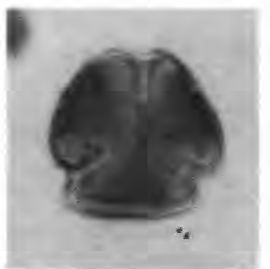

23
PROFESSIONAL PAPER 1448 PLATE 10

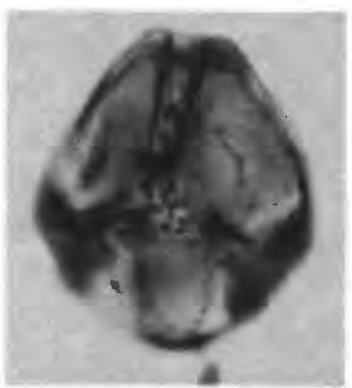

4

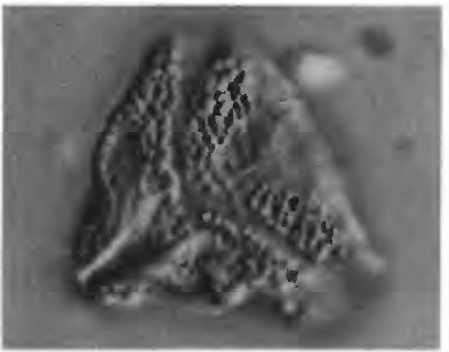

8

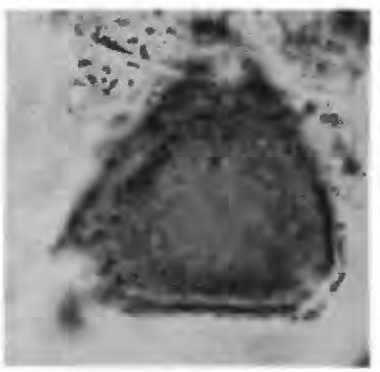

12

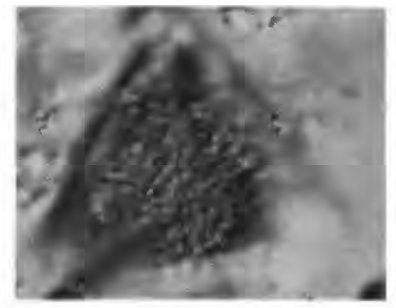

13

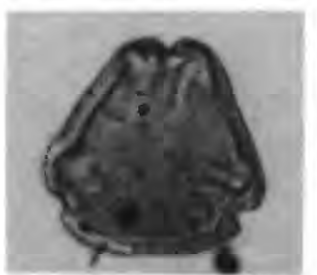

24 


\section{PLATE 11}

[Magnification $\times 1,000$ ]

Figures 1-9. Nyssapollenites spp. 1-4, Dobys Bluff Tongue (Dockery 1980), Kosciusko Formation (of Thomas, 1942), eastern Mississippi; 5-9, Lisbon Formation, western Alabama.

10-16. Lanagiopollis crassa type (OTU 295). 10, 11, Basic City Shale Member, Tallahatta Formation, eastern Mississippi; 12-16, Tallahatta Formation, western Alabama.

17. Lanagiopollis cribellata (Srivastava 1972) n. comb. Note thinness of exine in this species compared with Eocene species of Lanagiopollis of Alangiaceae type (plates 12, 13). Oak Hill Member, Naheola Formation (upper Paleocene), western Alabama. 
DEPARTMENT OF THE INTERIOR

U.S. GEOLOGICAL SURVEY

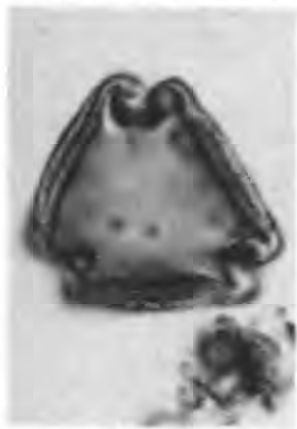

1

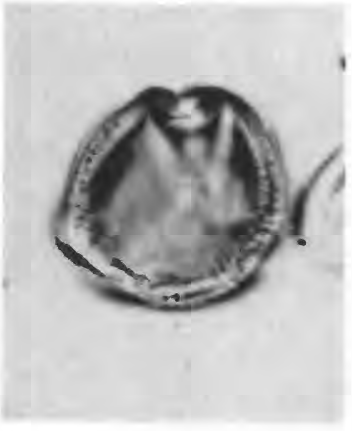

5

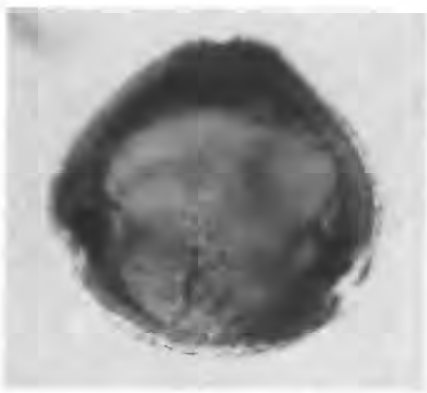

10

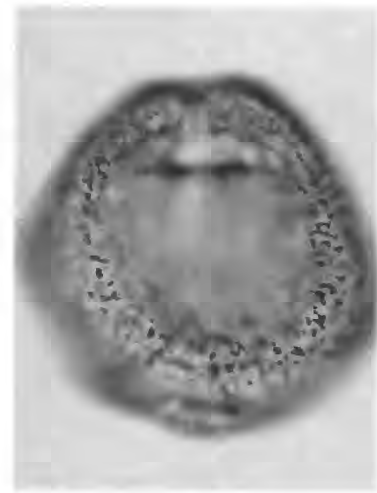

14

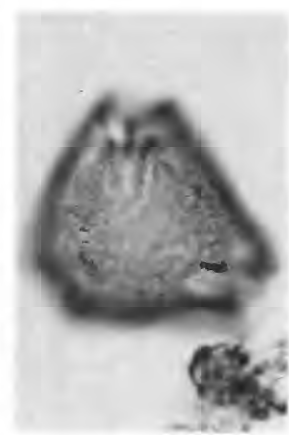

2

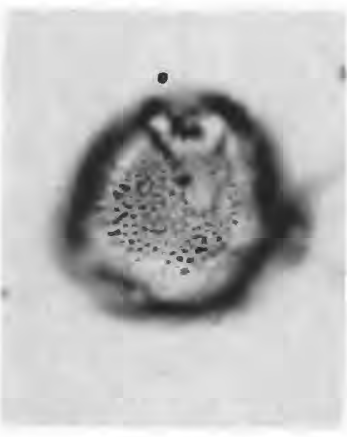

6

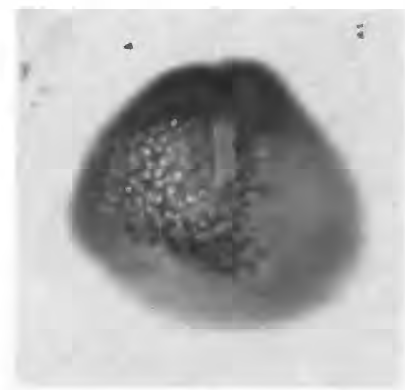

11

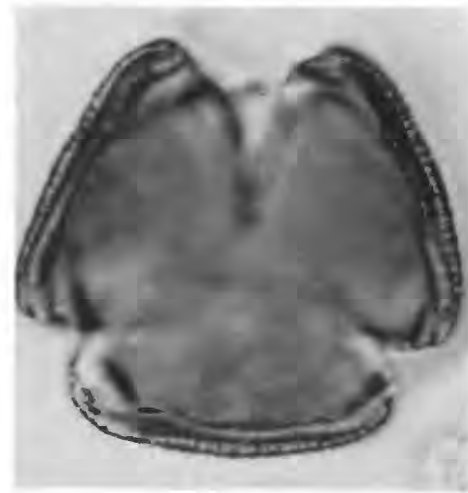

15

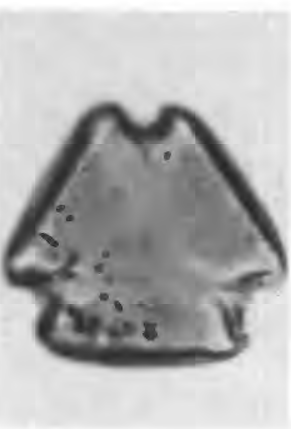

3
PROFESSIONAL PAPER 1448

PLATE 11

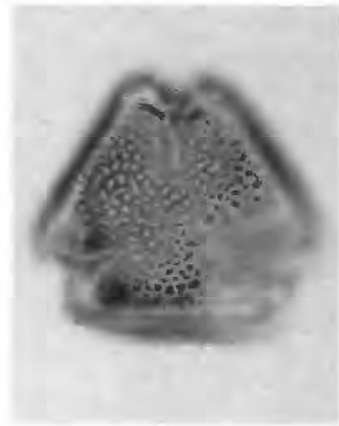

4

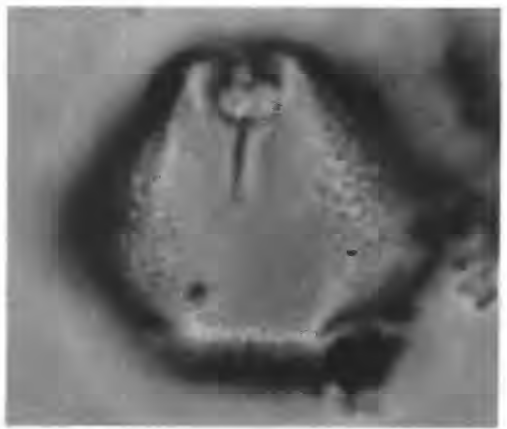

8

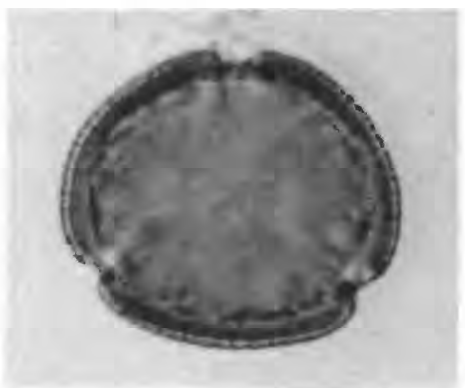

12

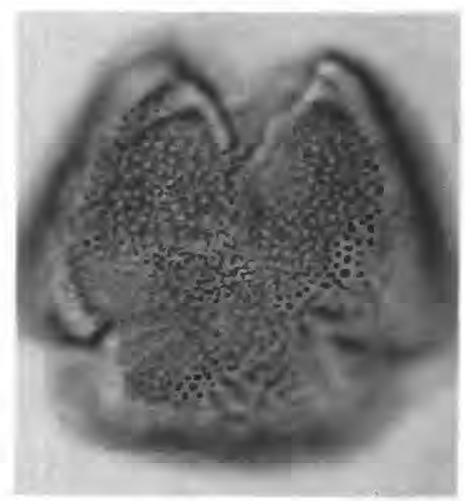

16

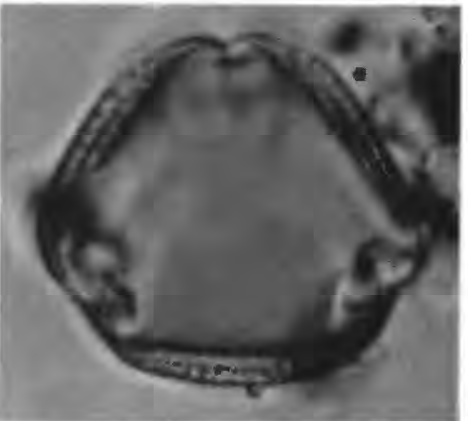

7

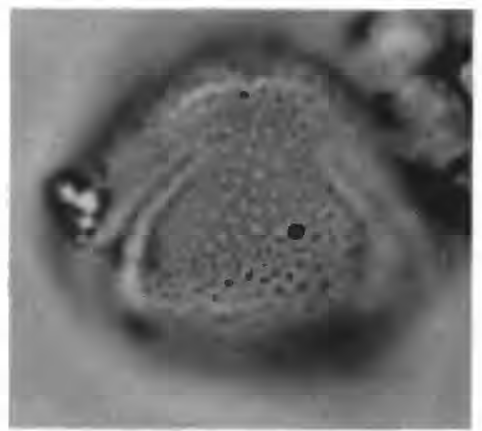

9

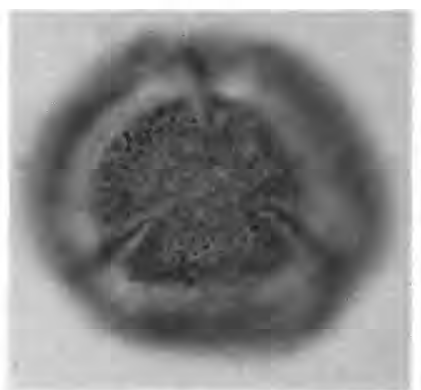

13

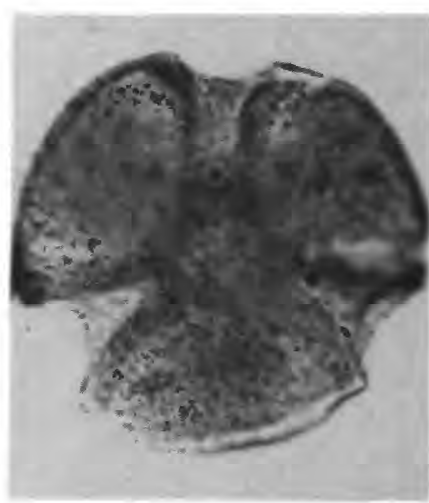

17 
PLATE 12

[Magnification $\times 1,000$ ]

FIgURES 1-3. Lanagiopollis sp. 1 (OTU 301). Albany core, western Georgia.

4-8. Lanagiopollis sp. 2 (OTU 303). Bashi Formation, eastern Alabama.

9, 10. Lanagiopollis eocaenica type (OTU 297). Albany core, western Georgia. 


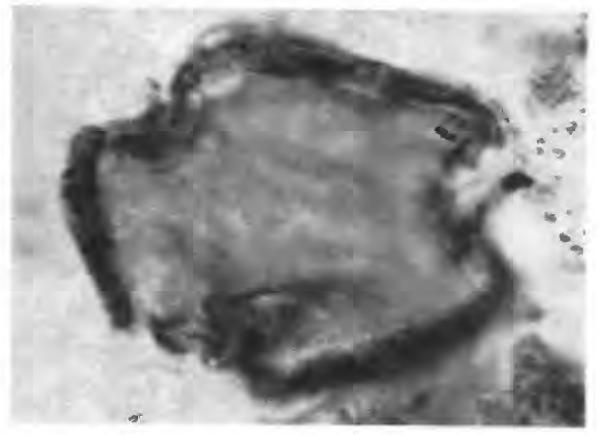

1

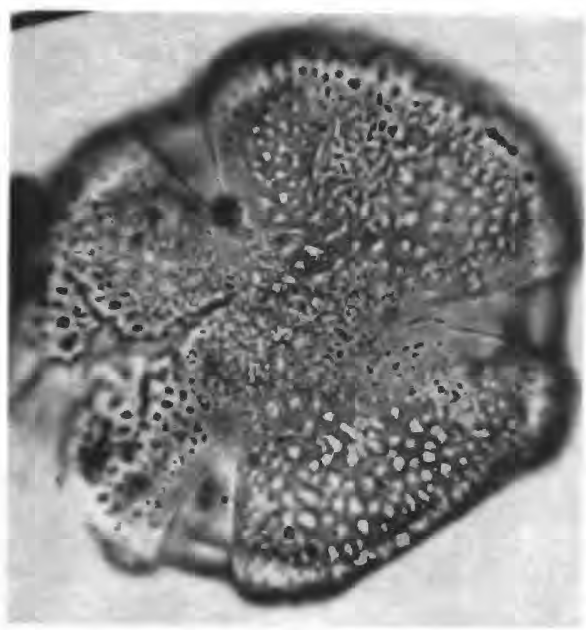

4

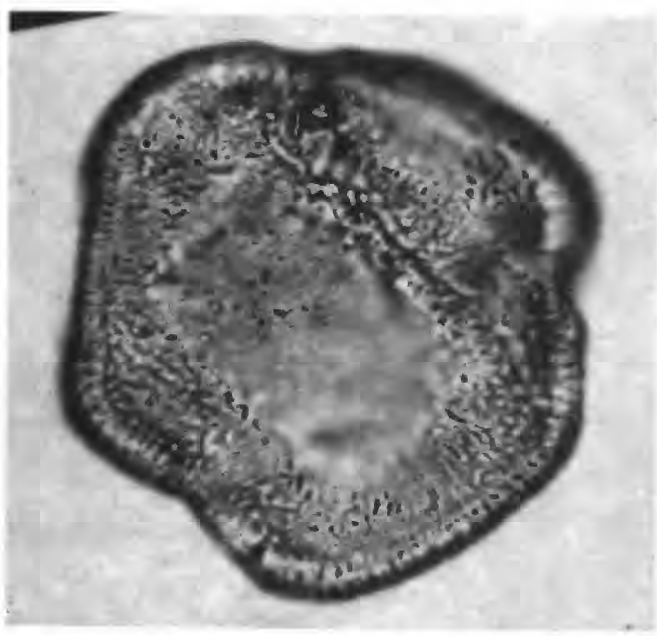

7

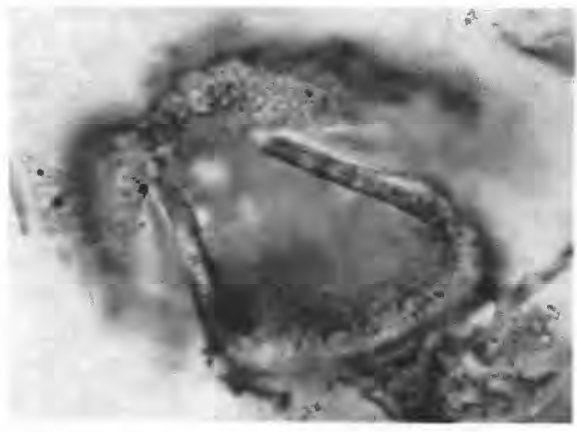

2

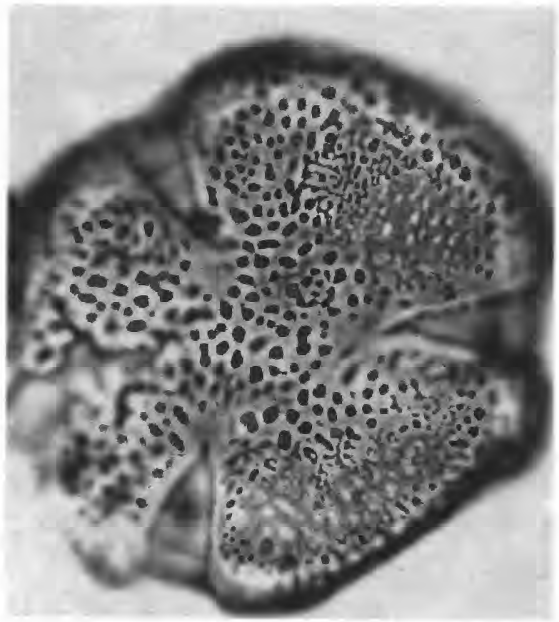

5

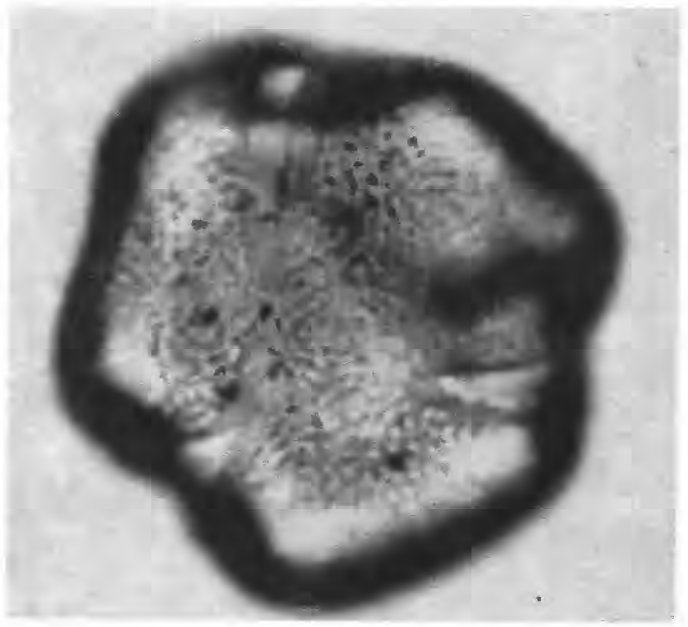

8

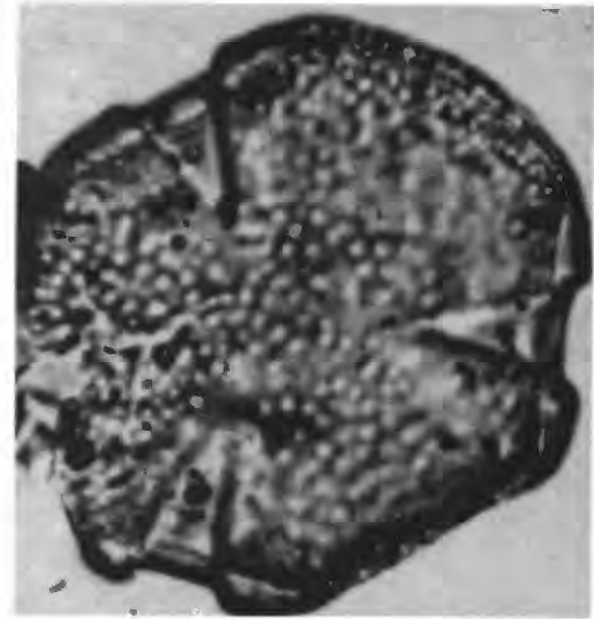

6

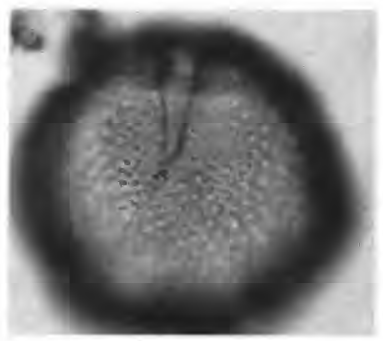

9

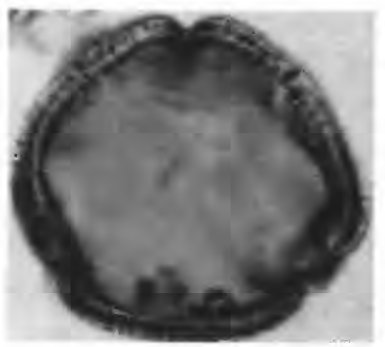

10 


\section{PLATE 13}

[Magnification $\times 1,000]$

FIgURES 1-3. Lanagiopollis eocaenica type (OTU 297). 1, 2, Tallahatta Formation, western Alabama; 3, Basic City Shale Member, Tallahatta Formation, eastern Mississippi.

4-12. Lanagiopollis hadrodictya n. sp. (OTU 299). 4-6, holotype, Albany core, western Georgia; 7, 8, Basic City Shale Member, Tallahatta Formation, eastern Mississippi; 9-11, Tallahatta Formation, western Alabama; 12, Lisbon Formation, western Alabama.

13, 14. Rhoipites capax n. sp. (OTU 247). Holotype. Lisbon Formation, western Alabama. 


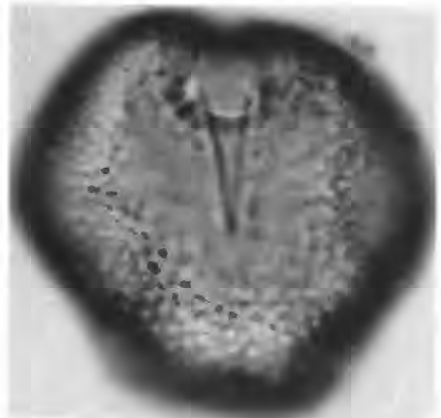

1

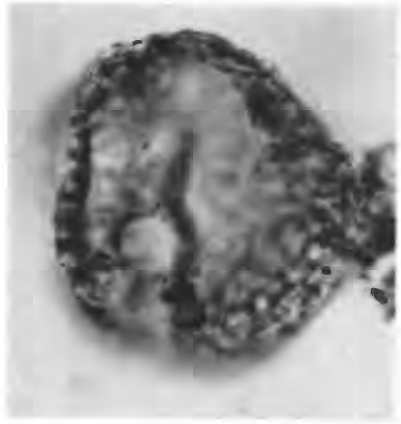

4

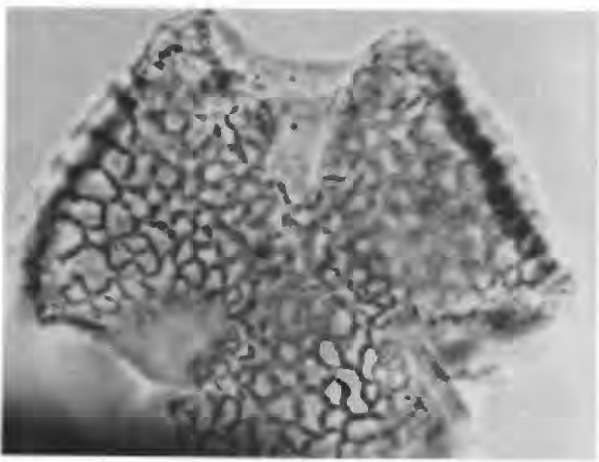

9

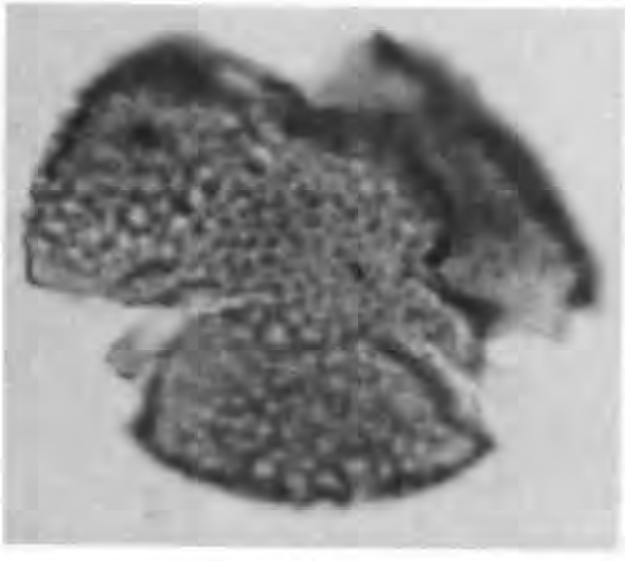

12

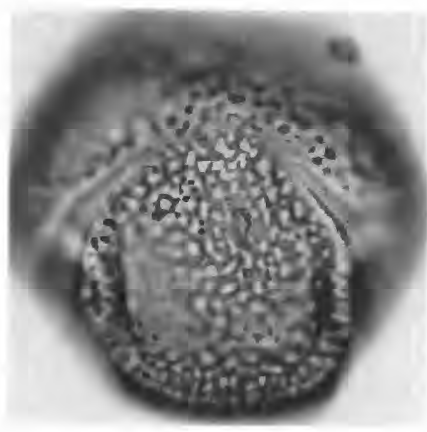

2

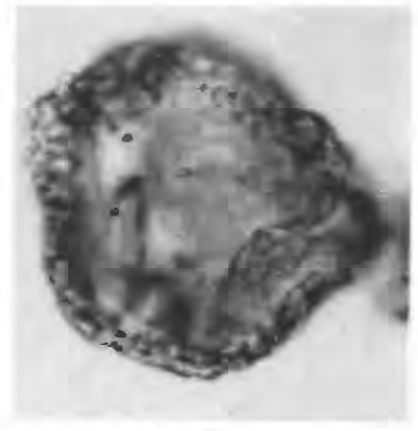

5

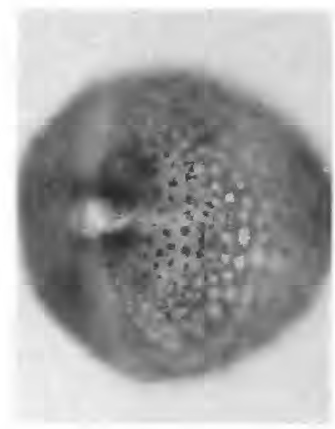

3

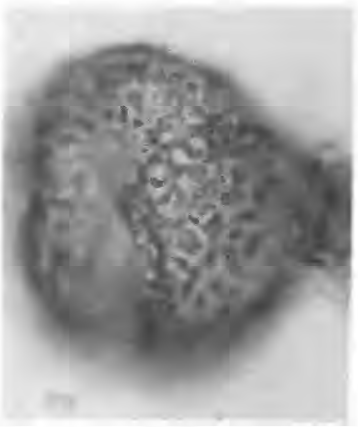

6

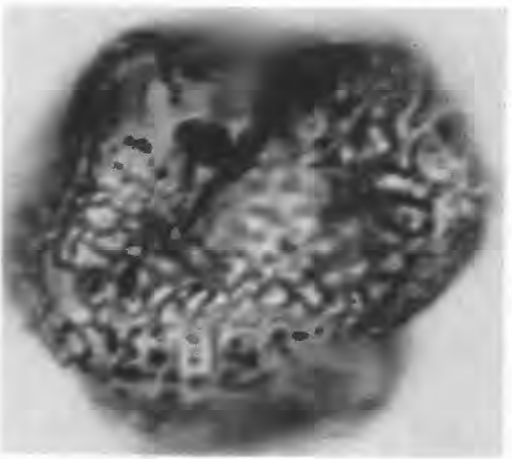

10

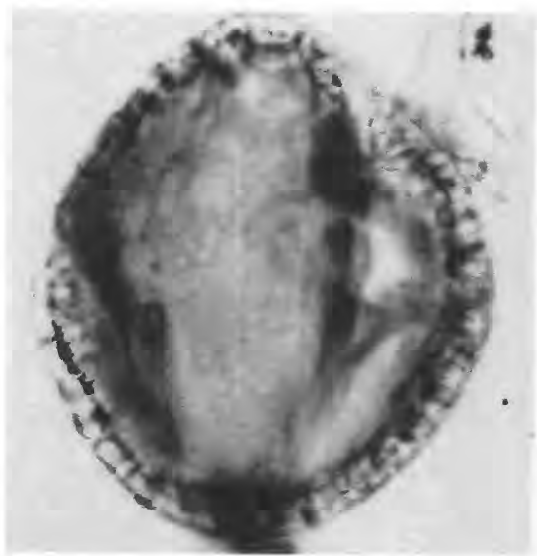

13

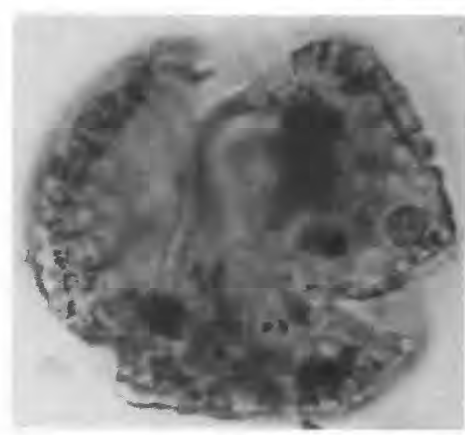

7

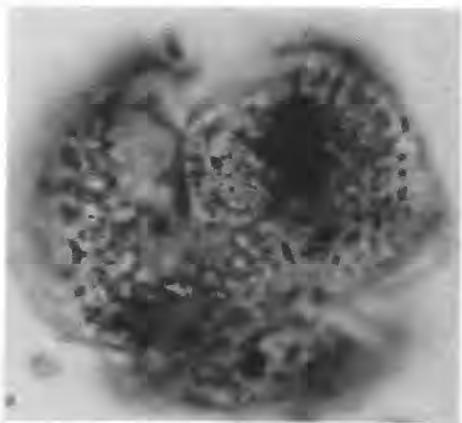

8

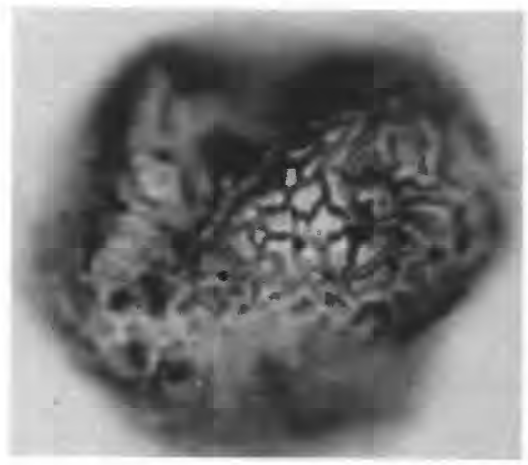

11

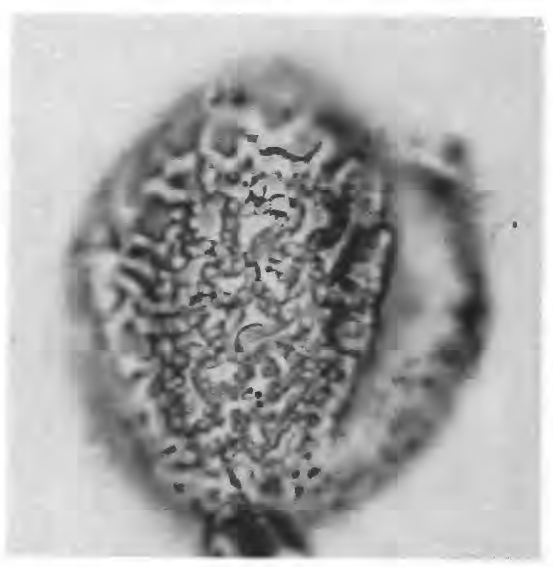

14

ANGIOSPERM POLLEN GRAINS 


\section{PLATE 14}

[Magnification $\times 1,000]$

FigURES 1-7. Rhoipites capax n. sp. (OTU 247). 1, 2, Lisbon Formation, western Alabama; 3-7, Albany core, western Georgia. 8-11. Bombapollis texensis Elsik 1974 (OTU 255). 8, focus on outer part of sexine, showing coarse reticulum; 9, focus on inner part of sexine, showing fine reticulum; 10, optical section. 8-10, Tallahatta Formation, western Alabama; 11, Albany core, western Georgia.

12, 13. Bombacacidites sp. Interference contrast. Lisbon Formation, western Alabama.

14-18. Bombacacidites sp. 2 (OTU 319). 14, 15, Bashi Formation, eastern Alabama; 16-18, Albany core, western Georgia. 


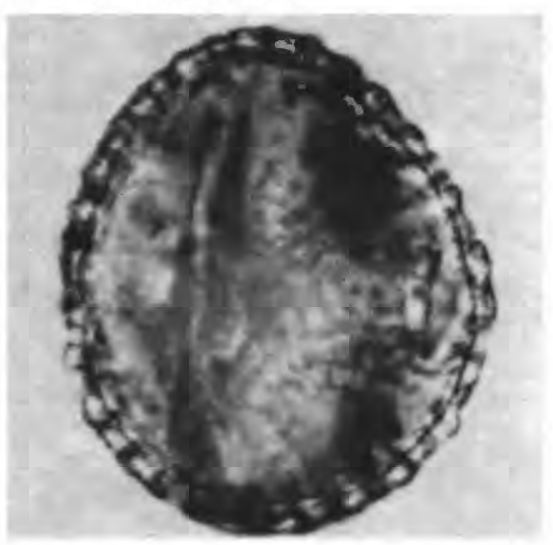

1

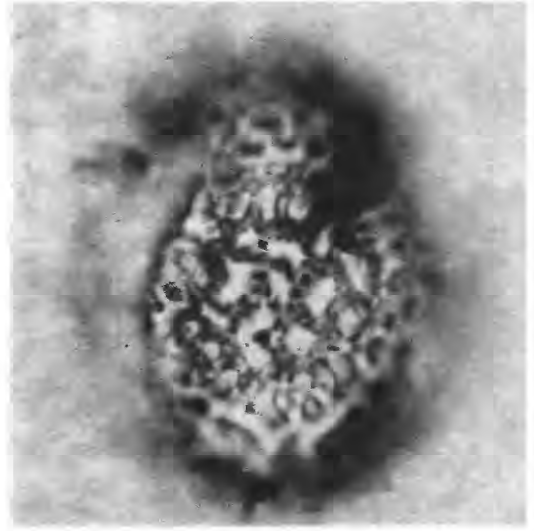

2

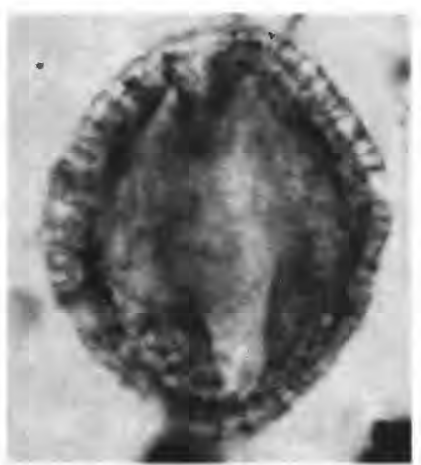

3

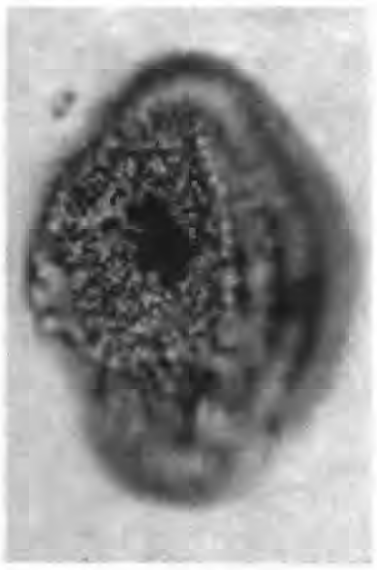

8

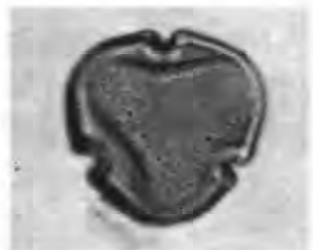

14

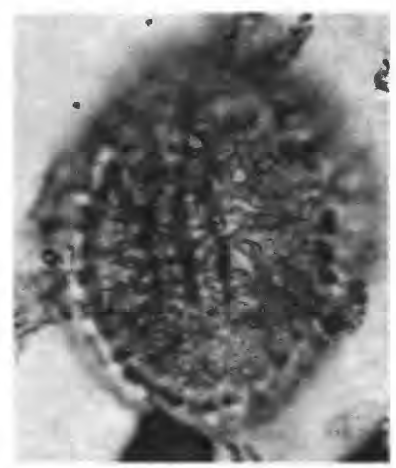

4

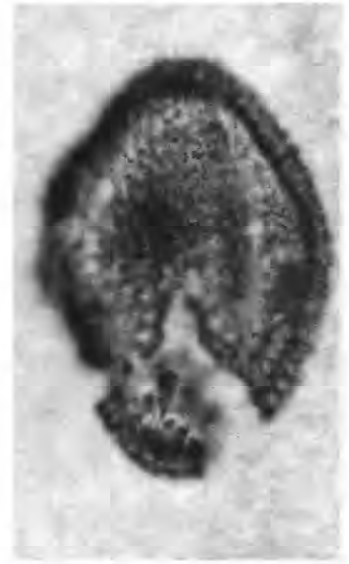

9

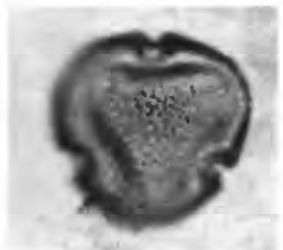

15

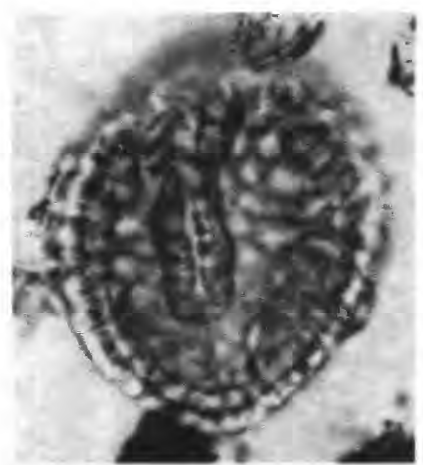

5

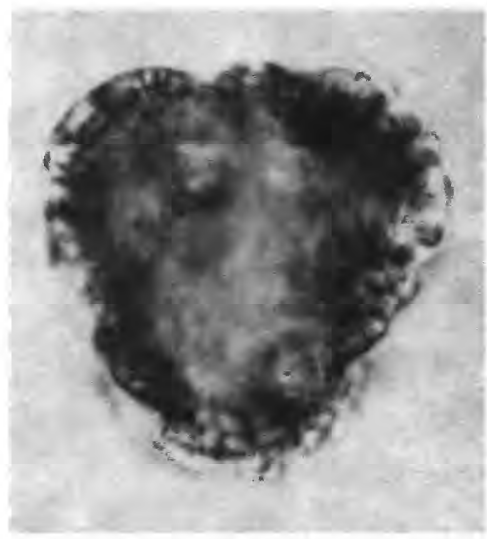

6

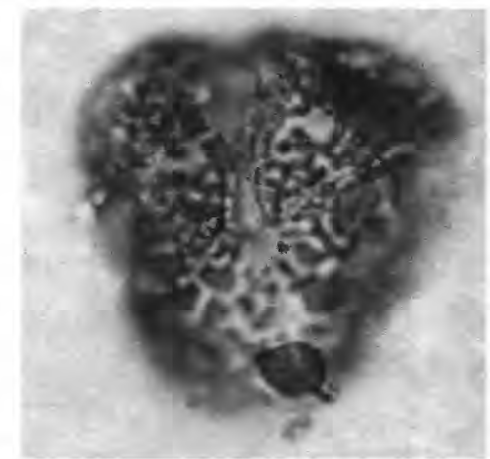

7

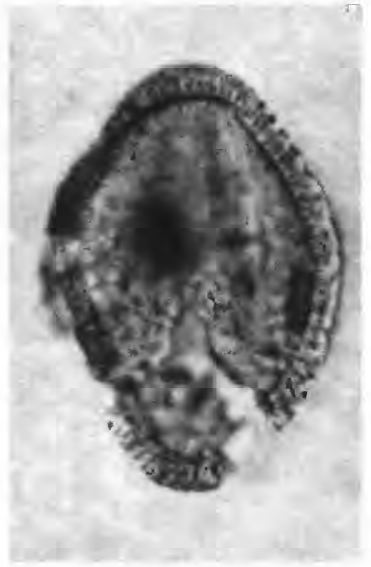

10

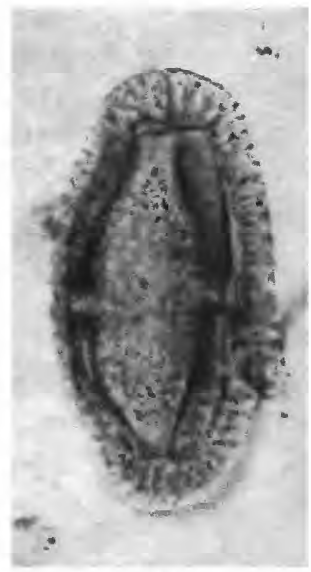

11

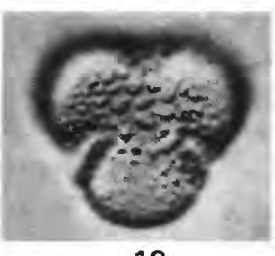

12

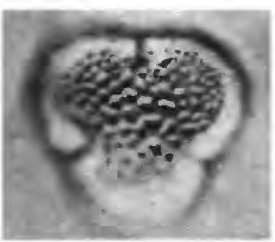

13

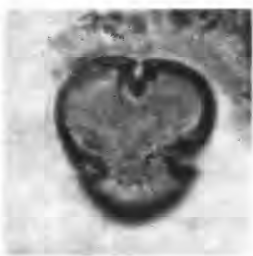

16

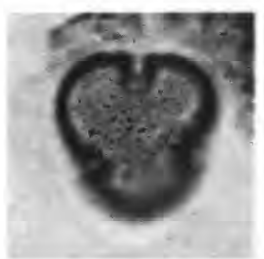

17

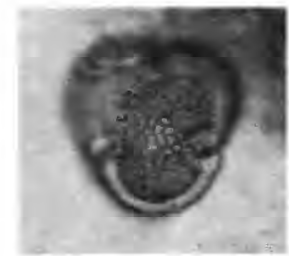

18

ANGIOSPERM POLLEN GRAINS 


\section{PLATE 15}

[Magnification $\times 1,000]$

FIGURES 1-4. Bombacacidites aff. B. nanobrochatus Frederiksen 1983 (OTU 305). 3, 4, interference contrast. 1-4, Hatchetigbee Formation, western Alabama.

5. Bombacacidites fereparilis Frederiksen 1983 (OTU 309). Hatchetigbee Formation, western Alabama.

6-10. Bombacacidites sp. 1 (OTU 317). 6-8, Hatchetigbee Formation, western Alabama; 9, 10, Hatchetigbee Formation, eastern Alabama (interference contrast).

11, 12. Bombacacidites nacimientoensis (Anderson 1960) Elsik 1968 (OTU 311). Interference contrast. This specimen has slightly more rounded corners than is usual for the species. Hatchetigbee Formation, western Alabama.

13-15. Bombacacidites ef. B. nanobrochatus Frederiksen 1983 (OTU 307). 13, 14, interference contrast. 13, 15, Tallahatta Formation, western Alabama; 14, Basic City Shale Member, Tallahatta Formation, eastern Mississippi.

16, 17. Bombacacidites aff. B. reticulatus Krutzsch 1961 (OTU 315). 16, Hatchetigbee Formation, eastern Alabama; 17, Hatchetigbee Formation, western Alabama.

18-20. Bombacacidites cf. B. nanobrochatus Frederiksen 1983 (OTU 307). 19, 20, interference contrast. 18, Tallahatta Formation, western Georgia; 19, Tallahatta Formation, western Alabama; 20, Albany core, western Georgia.

21, 22. Intratriporopollenites pseudinstructus group (OTU 323). Bashi Formation, eastern Alabama.

23. Intratriporopollenites stavensis Frederiksen 1980 (OTU 325). Interference contrast. Tallahatta Formation, western Alabama.

24, 25. Intratriporopollenites cf. I. stavensis. This specimen is heterobrochate. Interference contrast. Dobys Bluff Tongue (Dockery, 1980), Kosciusko Formation (of Thomas, 1942), eastern Mississippi. 
DEPARTMENT OF THE INTERIOR

U.S. GEOLOGICAL SURVEY

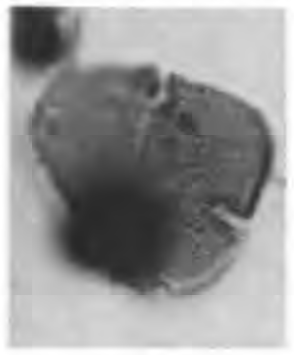

1

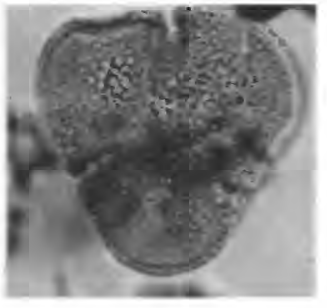

6

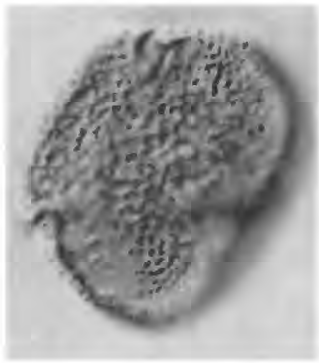

11

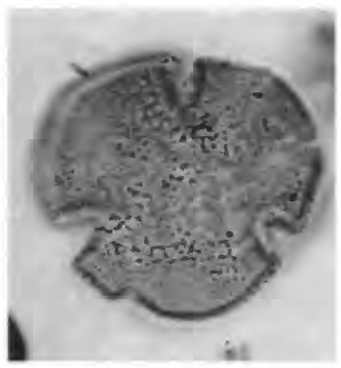

16

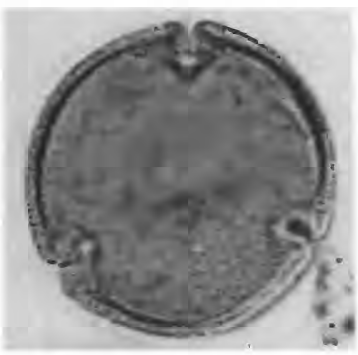

21

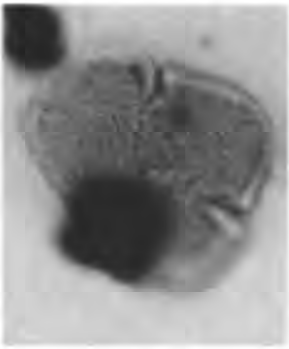

2

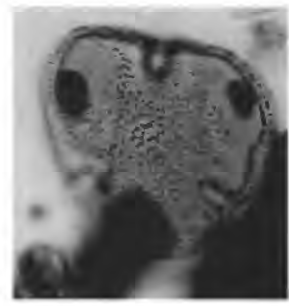

7

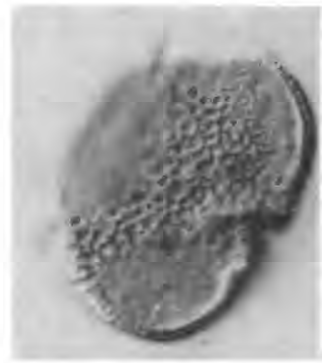

12

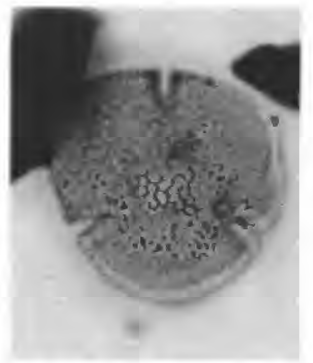

17

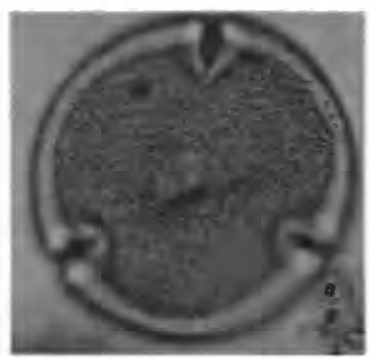

22

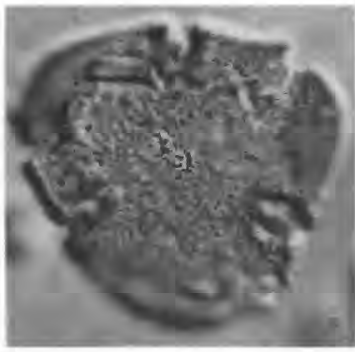

3

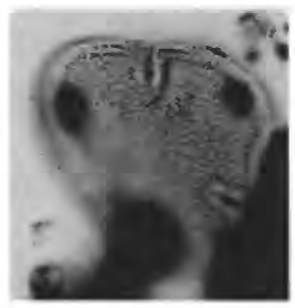

8

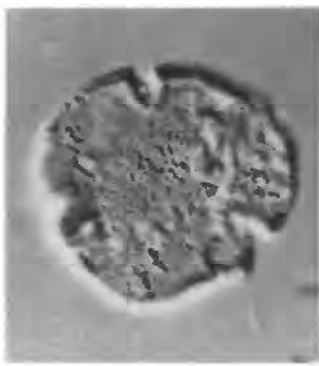

13

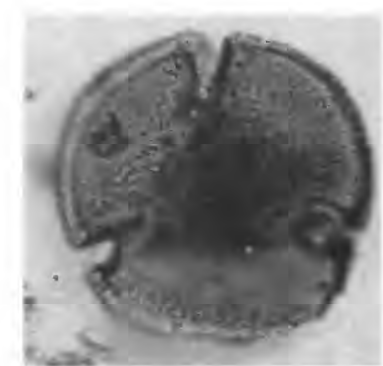

18

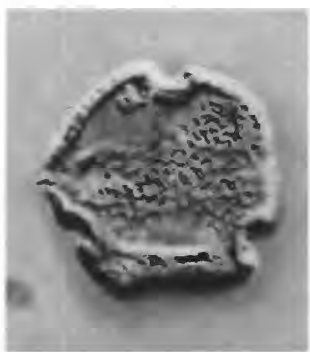

23

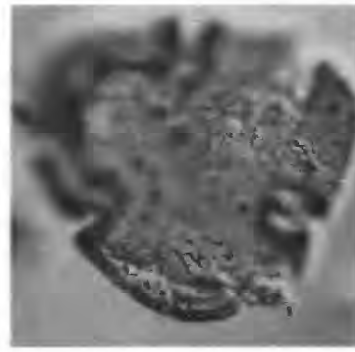

4

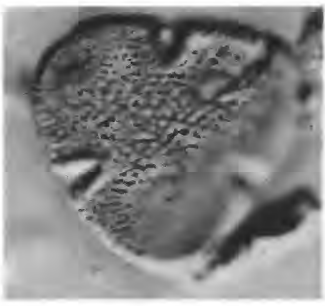

9

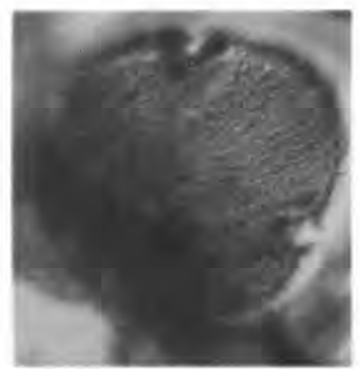

14

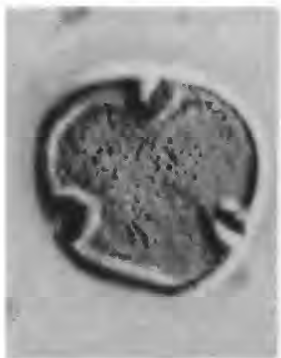

19

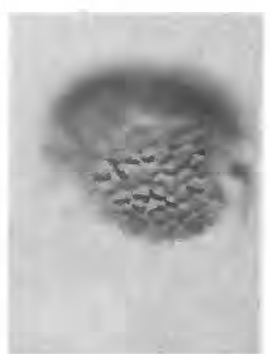

24
PROFESSIONAL PAPER 1448
PLATE 15

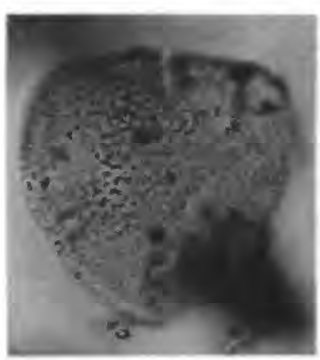

5

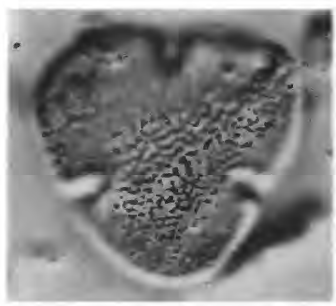

10

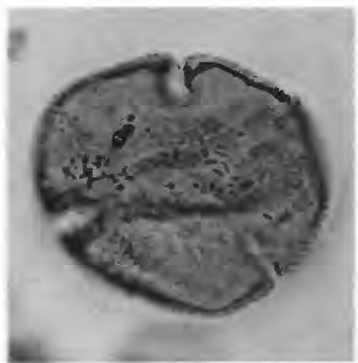

15

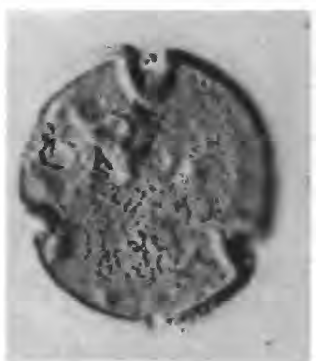

20

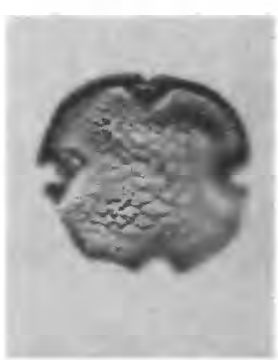

25

ANGIOSPERM POLLEN GRAINS 


\section{PLATE 16}

[Magnification $\times 1,000$ ]

FIGURES 1-3. Intratriporopollenites? sp. 1 (OTU 327). 1-3, Basic City Shale Member, Tallahatta Formation, eastern Mississippi.

4. Retibrevitricolpites sp. Basic City Shale Member, Tallahatta Formation, eastern Mississippi.

5. Friedrichipollis sp. 1 (OTU 331). Basic City Shale Member, Tallahatta Formation, eastern Mississippi.

6, 7. Friedrichipollis sp. Interference contrast. The reticulum in the outer part of the sexine in this specimen is finer than it is in Friedrichipollis duploreticulatus Krutzsch 1970. This specimen is more triangular in outline than Friedrichipollis sp. 1 of this paper.

8, 9. Ailanthipites berryi Wodehouse 1933 (OTU 335). Lisbon Formation, western Alabama.

10, 11. Retibrevitricolpites sp. Lisbon Formation, western Alabama.

12, 13. Tetracolporopollenites brevis type (OTU 339). Lisbon Formation, western Alabama.

14-16. Tetracolporopollenites lesquereuxianus type (OTU 341). 15, 16 is similar to Manilkara longipollinia Traverse 1955. 14-16, Lisbon Formation, western Alabama. 
DEPARTMENT OF THE INTERIOR

U.S. GEOLOGICAL SURVEY

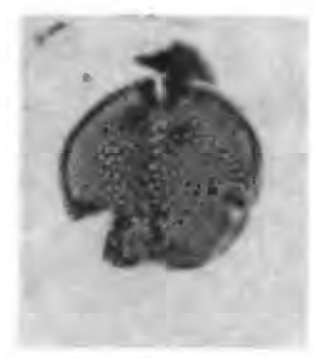

1

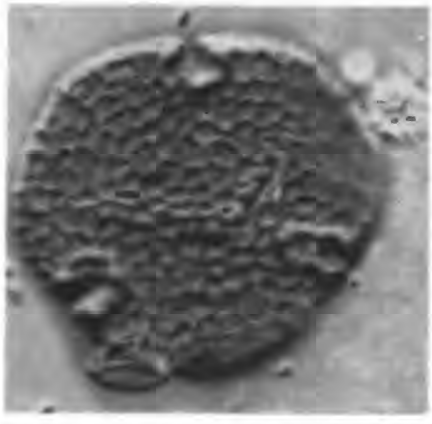

6

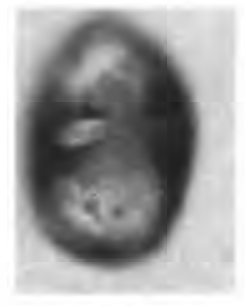

12

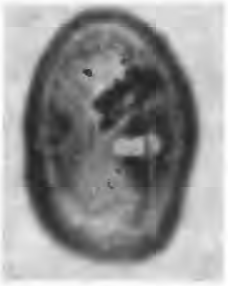

13

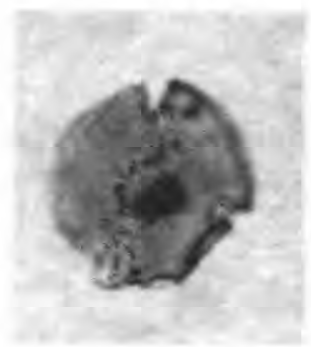

2

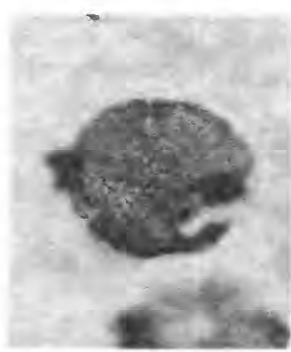

3

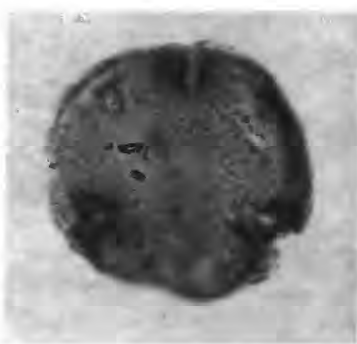

4

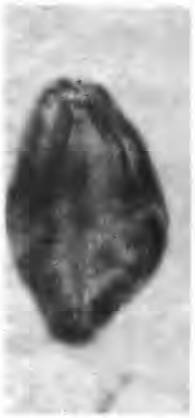

8

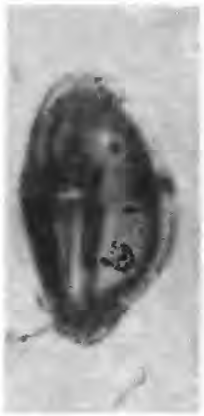

9

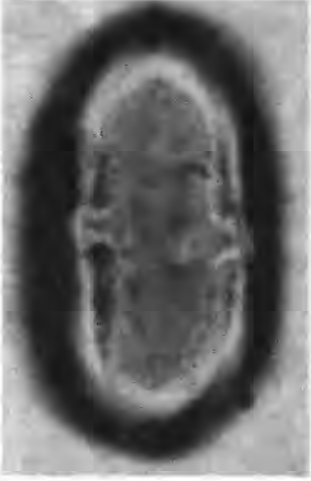

16
PROFESSIONAL PAPER 1448 PLATE 16

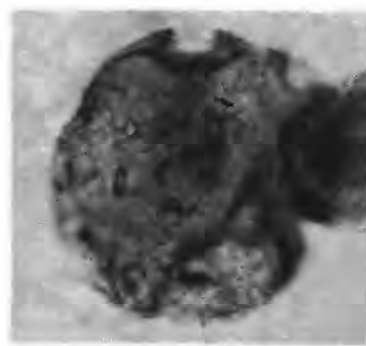

5

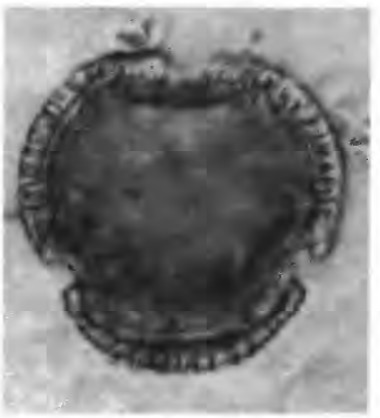

10

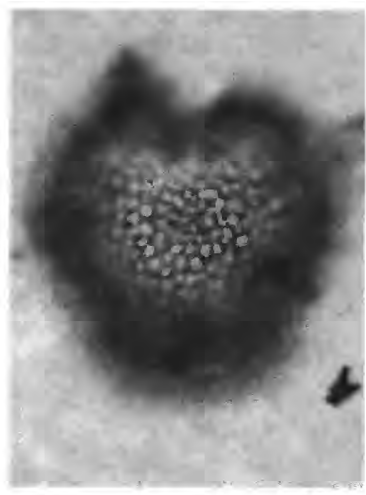

11 